

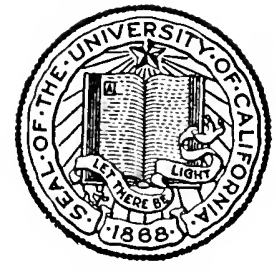

\section{THE LIBRARY OF}

SANTA BARBARA

COLLEGE OF THE UNIVERSITY

OF CALIFORNIA

PRESENTED BY

MRS. J. R. SACKRIOER 


\section{Digitized by the Internet Archive in 2008 with funding from Microsoft Corporation}



ANGLO-AMERICAN MEMORIES

SECOND SERIES 


\title{
ANGLO-AMERICAN MEMORIES
}

SECOND SERIES

\author{
BY \\ GEORGE W. SMALLEY, M.A.
}

"I have found among my possessions none that I so much prize and esteem as a knowledge of the actions of great men."

Machiavelli.-The Prince.

G. P. PUTNAM'S SONS

NEW YORK AND LONDON Tbe knickerbocker $\mathbb{p r c s g}$ 1912 
Printed in England by H'illian Brindon and Son, Ltd., Plymouth 


\section{PREFACE}

$\mathrm{N}$ the sentence from Machiavelli quoted on the title-page the phrase "great men" is used loosely, and most people use it loosely. Nature is not so lavish as all that. If she gives us one or two great men in a century let us be thankful for the one or two and, as to the rest, discriminate. To be a great orator or a great politician is not necessarily to be a great man. But the quality of greatness is there and we need not demand that it shall be so complete as to envelop the man. I have written about the men who interest me in the hope that what I say of them may interest others.

All these papers are the work of the last year or two. They are, like the first series, strictly what I have called them, Memories. I have never kept a journal and seldom taken a note. If it should occur to anybody that other personages might have been included in the first series, or in the second, I may say that in earlier books of mine, and in magazines, and still more in $T$ be New York Tribune, for which most of these Memories were originally written, many other names will be found; and there may be more hereafter.

The study of Mr. Whitelaw Reid was not sent to that paper, since, although on accepting the London Embassy he ceased to be its Editor, he remained chief proprietor. The chapters now republished have been revised and some have been re-written or enlarged. For my opinions and indiscretions I only am responsible.

LONDON, Jamuary, 1912.

G. W. S. 



\section{CONTENTS}

CHAPTER I PAGB

Mr. Chamberlain $. \quad . \quad$. . . . . . $\mathbf{I}$

CHAPTER II

The Eighth Duke of Devonshire . . . 22

CHAPTER III

The Late Duchess of Devonshire . . . . 37

CHAPTER IV

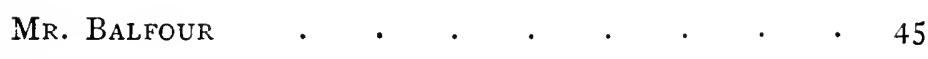

CHAPTER V

Sir William Harcourt-Domestic and Political Recollections . . . . . . . . . 6I

CHAPTER VI

Lord Rosebery-A Personal View of an English Statesman . . . . . . . . . 68

CHAPTER VII

Field-Marshal Viscount Wolseley . . . . 79

CHAPTER VIII

Mr. Winston Churchill-The Boy and the Man.$s_{7}$

CHAPTER IX

Sir Edward Grex-A Personal and Diplomatic IMPRESSION . . . . . . . . 102 
CHAPTER $\mathrm{X}$

Viscount Haldane-IVar Minister, Metaphysician, pagb Lawyer, and Socialistic Radical . II 2

CHAPTER XI

Four Speakers of the House of Commons - II

CHAPTER XII

The Fifth Earl Spencer - $\quad$ 34

CHAP'TER XIII

The Late Viscount Goschen-A Very Individual Anglo-German Englishman . . . . . I 49

CHAPTER XIV

Mr. Goldiwin Smith-Scholar, Apostle, Historian, IVRITER OF ENGLISH - ${ }^{56}$

CHAPTER XV

Prince Francis of Teck I63

CHAPTER XVI

Lord Pauncefote as Anglo-American ambassador . 170

CHAPTER XVII

The Present American Ambassador, Mr. Whitelaw REID

CHAPTER XVIII

Two Methods of Diplomacy-American and European 198

CHAPTER XIX

The American Speaker, Mr. Thomas B. Reed . . 208

CHAPTER XX

Mr. Junius S. Morgan 
CHAPTER XXI

page

Mr. Pierpont Morgan

. 221

CHAPTER XXII

Mr. Andrew Carnegie

\section{CHAPTER XXIII}

Mr. Willian Waldorf Astor and His Experiences in England - $26 \mathrm{I}$

CHAPTER XXIV

Mr. Janes McNeill IVhistler-Anecdotes, Estimates, FRIENDSHIPS 276

CHAPTER XXV

Sir William Schwenck Gilbert . . . . . 289

CHAPTER XXVI

Mlle. Ainée Desclée-Her Art, Her letters, Her LIFE . 296

CHAPTER XXVII

Sir Henry Irving $\quad . \quad \cdot \quad \cdot \quad \cdot \quad \cdot \quad \cdot 308$

CHAPTER XXVIII

Mme. Sarah Bernhardt and Sir Henry Irving • 327

CHAPTER XXIX

Mr. Theodore RoOsevelt

CHAPTER XXX

Count Witte and What He Did at Portsmouth . $38_{3}$ 



\section{ANGLO-AMERICAN MEMORIES}

SECOND SERIES

CHAPTER I

MR. CHAMBERLAIN

I

IANDING on Dover pier at four o'clock in the morning, after a turbulent voyage from Calais, I met Mr. John Morley and walked with him along the still more turbulent railway platform to his compartment. He told me Mr. Chamberlain was with him and asked me to come in. When I said I did not know Mr. Chamberlain, he answered it was time I did, and introduced me. This was more than thirty years ago, and so began my acquaintance with the man who then was reckoned the foremost Radical in England. We talked from Dover to London, while Mr. Morley slept. During those two hours his Radicalism was aflame, and he seemed ready enough to declare his opinions with more freedom than most Englishmen use to a new-comer. Needless to say he talked with picturesque energy; whether about persons or politics; and ever in an uncompromising tone. He discoursed among other things 
on Mr. Forster's Education Act of 1870 , which later he described as one of the greatest measures, or perhaps the greatest, Parliament had ever passed. But that morning he was in no mood for eulogy. $\mathrm{He}$ was in his finest Nonconformist temper and nowise disposed to make light of Mr. Forster's compromises which to him seemed, taken together, a surrender to the Church of England. I was so much struck with his implacable tone that I asked :

"Shall you never forgive Mr. Forster ?"

"Never."

Mr. Chamberlain did not then foresee that he was himself to undergo changes of opinion compared to which Mr. Forster's concessions were of little moment. All the more precious is this first memory of him in his original state; which I imagine he himself might call unregenerate. There was the real Chamberlain in all the fervour of convictions that admitted then of no doubt, that to him formed part of the law of the Universe. The Chamberlains who have succeeded to this one have been just as real, just as sincere, and each one, I suppose, just as sure of the permanence of the beliefs of each.

Often taunted with versatility, his old speeches often quoted against him, he has answered with unshaken composure that mere consistency is no part of a Minister's outfit. Opinions change because circumstances change. An open mind, an essential sincerity of character, a clear view of what at the moment the public good requires of a public servantthose are the qualities a useful Minister must possess. Even his enemies, perhaps even the Irish Home Rulers whom he overcame, do not deny to him these traits. As I think of the attacks on him, surpassing in bitterness those on any other man of his time, 
I think also of what an American said of President Cleveland :

"I love him for the enemies he has made."

And so, in the heat of conflict, and by influences stronger than individual opinions, and ever in stress and storm, was slowly fashioned the Chamberlain whom all men at last recognized as one of the great forces of English Conservatism and English life.

Perhaps the rarest of all political products in these British Isles is the man of ideas. Rarer still is the man who, having ideas, has also the gift of political leadership, which includes political courage. Mr. Chamberlain is that man, and that is why, five years after illness had driven him from public life, England celebrates his seventy-fifth birthday with as much heartiness as if he were still, where for thirty years he had ever been, in the forefront of battle. There he will never be again. His mind has still much of its old vigour, but paralysis, or something like it, bereft him of his physical strength, and left him, though not speechless, wholly incapable of addressing either the House of Commons or a public meeting. He writes now and then a letter to a Unionist candidate for Parliament or a brief epistle on some pressing topic; lucid, effective, because they are his, but never quite in the old tone. So far as fresh effort is concerned, he is a spent force, but the influence of his name and of his life-work will never be spent.

Napoleon was wont to call men who mixed theory with practice idéologues. He hated them; and he also despised them, since, in his view, their habit of speculation impaired their power of will and of work. He might have hated Mr. Chamberlain. He would never have despised him. Seldom, if 
ever, has there been an Englishman whose power of will and of work was greater than his. If you look at Lawrence's portrait of the younger Pitt, you will see the features of Mr. Chamberlain, and you may well suppose that this statesman of the nineteenth century could have carried on Pitt's twenty years' struggle with Napoleon, and freed Europe. Pitt died an old man at forty-six, worn out. Mr. Chamberlain lasted till seventy.

Mr. Gladstone excepted, I have known no Englishman who gave you such an impression of concentrated energy as Mr. Chamberlain. Whether he talked to you, whether he talked to a crowded House of Commons, whether he talked to six thousand people in Birmingham Town Hall, whether he sat silent, the impression was the same. Into that slender, sinewy frame of no great height his Maker had packed the essential energies of a great race. I have met him in all sorts of circumstances; never once when his was not the dominant personality of the scene. I can think of nobody in recent times to compare him with except the late Prime Minister of France, M. Clemenceau. They had this in common, that each married an American wife, and among all the gifts the gods have bestowed on the Englishman, his American wife is one of the most precious. But the great Frenchman is so little known to Americans that the comparison would be futile. Nor is any comparison of much use except as an illustration of particular traits. Nor will any description of $\mathrm{Mr}$. Chamberlain avail unless you have seen and heard the man himself, and then it is superfluous.

But look at him on the platform at Birmingham, among his own people, in the arena where some of his most splendid triumphs have been won. As he 
comes forward a roar of welcome greets him. You see that he and his fellow-townsmen are on affectionate terms. They know what they owe him. They remember that long before he served England he served Birmingham; was thrice Mayor of that great city, and made it an example to every municipality in Great Britain. A business man, first of all; an administrator, an organizer. He begins his speech in a business tone. His attack is instantaneous. Almost with his first sentence he is in the heart of his subject. No generalities, no rhetoric, not a word of appeal to his audience; no preface, no exordium. As if by instinct, he goes straight to the matter in hand. His voice rings clear and there is in it the unmistakable accent of sincerity. He knows Birmingham like an old glove, and the men of Birmingham as old friends. In the phrasing of his sentences there is a touch of intimacy almost conversational. Try to converse with six thousand people, and see if you find it easy.

In point of fact, this air of artlessness is calculated. He knows all that can be known about the art of public speaking. $\mathrm{He}$ knows what sentences will carry, to use the stage term, and what will not. Profoundly in earnest, still he is an actor; and a most accomplished actor. You cannot be a great actor unless you have the dramatic gift. Mr. Gladstone had it, but in him it was almost too visible. Mr. Bright had it, but his art was reduced to its final expression of complete simplicity, and no one who listened to him suspected the art. He spoke as the messenger of the Almighty. To those heights Mr. Chamberlain did not often reach, nor did he make, as Mr. Bright did, a supremely imaginative use of his material. Mr. Bright had tones in his 
voice which were the tones of an organ. Mr. Chamberlain had not. He was far too wise and far too individual to attempt to rival, still less to imitate, Mr. Bright or anybody else. Mr. Bright was emotional; Mr. Chamberlain never. One thing they had in common: a profound sympathy with the people; as Lincoln had; and a command of the words by which sympathy of that kind declared itself; in each of the three differently, and in Mr. Chamberlain without your perceiving that the view he presented to you was anything but intellectual.

So close was the tie between him and his Birmingham audience, that you felt as if you were intruding on a family party. It was a great political occasion, but it was domestic; a Round Table about which all the Six Thousand were sitting. It was a Conference. You wondered how it was possible for that keen-faced figure on the platform to get into these obviously confidential relations with all these gunmakers and ironmongers of this Midland city which turns out hardware for all the world, the United States excepted. But he himself is of steel; elastic, polished, tempered as a sword is tempered, with an edge not less trenchant. He wields a shining blade which no armour can turn, as his enemies have found out. He delivers his thrust quietly enough, imperturbably, without malice and without mercy. In his face there is no sign of the fierce delight you see in the faces of those for whose pleasure he impales their common enemy. His attitude is scientific. These processes of vivisection are not primarily to give pain, but to increase knowledge.

In portraits and caricatures you see him always with an eyeglass and an orchid. The straw which Puncb put into Palmerston's mouth, and the legs 
of Lord John Russell on the Front Bench, too short to reach the floor, were alike efforts of the imagination. Mr. Chamberlain's single eyeglass and orchid are real. You never see him without both, and you never notice either. What you see is a man. He does not strike you as big, nor yet as little. He is just a man : and a man tremendously alive. The measurement you take of him is not an outward measurement. What you would like to measure, and cannot, is the man's soul. Your unconscious effort is to give to yourself an account of the nature of this extraordinary being, and of the contents of the skull, which is of no extraordinary size. When Gambetta died they weighed his brain, and found the weight of it under the average, not much more than forty-two ounces. The doctors were astonished. They had expected the weight of the brain to answer to the weight of character, and to the capacity of a mind which had at that time in France no second. Then they reflected that it was just as easy to explain his superiority by quality as by quantity, and were content. I imagine it is so with Mr. Chamberlain. The osseous structure is not ample enough for an unusual mass of brain; but the thinking power is there, and the will power; or, if not there, hidden away somewhere in the man, and the two together have been enough to enable him to work fifteen hours a day, full steam ahead. If he had not also smoked fifteen cigars a day, I might not have to use the past tense now in writing of his place in the life of England.

As his speech proceeds you become aware that the power of it proceeds also; grows more and not less with this prodigious expenditure of mental and physical force. It is a crescendo throughout. You cannot afford to relax your attention for an instant. 
There is no marking time. If he thinks on his legs, as he certainly does, the thinking never hinders the expression. The stream flows on like Matthew Arnold's Oxus ; brimming, and bright, and large. To say that as he proceeds he does not lose his hold on his hearers is nothing. He rivets their attention; moment by moment his grip tightens; the logic is pitiless; the invective more pitiless still; you bend to his passion; you are the captive to an unrelenting, argumentative sequence.

It is the Chamberlain I first saw and first heard in Birmingham that I am trying not to describe, but to outline; with a touch of colour if I could manage it. I heard him later in St. James's Hall in London, and elsewhere; a fairer test because his London audience was under no such spell as that of Birmingham and stood to him in no purely personal relation. But the effect, or my memory of it, is much the same. A test more searching still was the House of Commons, where he measured himself against the giants of those days.

The business of the House of Commons is, or once was, debate; it was in the days of Mr. Disraeli and of $\mathrm{Mr}$. Gladstone a deliberative assembly. Neither of those great leaders feared discussion or resorted to the systematic use of gag and guillotine to carry their Bills. They had other resources; nor had either adopted the theory of Grenville, the author of the Stamp Act, or of Mr. Asquith, the author of the Parliament Act, that to Parliament the whole power of the people had been delegated. Neither cared, as Grenville cared and Mr. Asquith now cares, to see Parliament despotic over the nation. Macaulay states the case against Grenville. For the case against Mr. Asquith you have but to read his own speeches. 
Not in Disraeli and not in Gladstone will you find a trace of either.

Mr. Chamberlain had therefore in those days a free course to run and he glorified. To-day he would be closured. He could be silenced if he could not be answered. But I was fortunate enough sometimes to hear him in a great debate, when the great men stood up to each other in fair combat. Perhaps as a debater no one of them was Mr. Chamberlain's superior. In other things they may have surpassed him. Mr. Gladstone certainly did in his amazing power of creating his own atmosphere in the House of Commons; of lifting debate to a level it never otherwise reached. But debate is a thing by itself and has rules of its own; as a contest with the sword has, which you neglect at your peril. In such a contest I do not know that either of the two was more than a match for Mr. Chamberlain.

\section{II}

It seems odd, considering all that has happened, to say so, but Mr. Chamberlain's decisive appearance in public life was due to his political alliance with the late Sir Charles Dilke. I give the facts as they were known to me at the time, from Dilke and a little from his friend; for the relations between the two were not political only; they were personal. I will say here once for all, in order to avoid re-entering upon a subject none too savoury-I mean Dilke's own subsequent history-that Mr. Chamberlain stood by Dilke when disaster came upon him; refused to believe-or to admit-what others knew to be true; refused to join in the attacks on him; defended him 
à tort et à travers. Whether he really thought Dilke innocent I, of course, do not know. He acted, at any rate, upon the maxim in the two Hares' Guesses at Truth, a book once current and still not wholly forgotten: "Friendship closes its eye rather than see the moon eclipst." I don't say it critically. I say it to Mr. Chamberlain's honour. His steadfastness to his friend was part of the steadfastness of his character.

When Dilke became M.P. for Chelsea, in 1868, the alliance between him and Mr. Chamberlain had already been formed; a singularly close alliance. By 1880 , when Mr. Disraeli's six years' reign ended, and Mr. Gladstone, mainly by help of the ever memorable Midlothian campaigns of $1879-80$, had driven his great rival from power, these two young men felt themselves strong enough to demand office. Dilke was then thirty-seven and Chamberlain forty-fourmere boys as age is commonly reckoned in English public life. They were the representatives of the New Radicalism inside the Liberal Party; a force destined to portentous growth, as anybody may see to-day; so portentous, so pregnant with disaster long before to-day, that Mr. Chamberlain had forsaken it even earlier than that gloomy winter of $1885-86$ when Mr. Gladstone took his fatal plunge into the dark waters of Home Rule. Even while he was yet the unchallenged leader of a united, or comparatively united, Liberal Party, Mr. Gladstone did not like Radicalism or Radicals. But it was his business as party chief to weigh the forces he had to deal with, and he recognized the claim these two men made on him, and sent for Sir Charles Dilke to offer him a post in the Ministry he was forming, though not in the Cabinet.

The story is told in different ways and the accounts, even those which may be called authoritative, cannot 
be easily reconciled. Lord Morley tells it, in his monumental Life of Gladstone, as usual, with great reserve; a Life of which frankness is not the prevailing note. The version I am going to give you is Dilke's version. I was at that time on friendly, and even intimate, terms with him; and saw him that afternoon at his house in Sloane Street. Mr. Chamberlain was present. Dilke had just come from Mr. Gladstone, and the offer of that subordinate place in the Government which the great leader thought adequate to Dilke's party claims had just been made. Without either accepting or declining it, he told Mr. Gladstone that he and Mr. Chamberlain were acting together; that both of them expected office; and that for one of them a place must be found in the Cabinet.

I give the substance and intent of Dilke's statement to Mr. Gladstone; very much as he himself gave it to me ; not at all, I imagine, as he phrased it when in presence of the great Liberal whom the Queen had asked, sorely against her will, to form a Ministry. Dilke's brevity of speech had, at times, a certain brutality, but it cannot be that he allowed himself this curt freedom of statement to Mr. Gladstone himself. Even upon Dilke, who respected few things, the authority of this wonderful old man must have made itself felt. Few were they who did not acknowledge and yield to it. But whatever the words in which Dilke delivered his ultimatum, Mr. Gladstone listened with his usual grave courtesy, and this was his answer :

"Sir Charles, you are as yet inexperienced in public life, and I think it a duty to explain to you that when a Prime Minister is forming a Government it is usual for him to distribute offices in accordance with his 
own conception of public duty. Never before have I known a case-never before have I heard of onewhere a young man who has never held office has thought himself entitled to dictate to a Prime Minister or to tell him he will accept, not the post tendered to him, but another post more to his taste. Still less has any candidate been known to impose conditions upon his acceptance, or to insist that two offices and not one shall be reserved for him and for a friend in whose behalf he speaks. You cannot be aware how far your attitude violates all tradition and political usage. You may realize this in part when you know by experience something about official life. And some day, when you shall find yourself engaged in the task which now occupies me, you will know how unprecedented and indefensible is your present attitude."

This rebuke was, in effect, addressed to Mr. Chamberlain as well as to Dilke, and was meant to be handed on by Dilke to his partner; and in substance was. I am not sure that it impressed either of the two very deeply. Mr. Chamberlain's seven years' seniority to his friend had cooled none of his fire. They knew very well, both of them, what they were doing; and I don't doubt that Mr. Chamberlain, who in knowledge of affairs and sagacity was superior to Dilke, had foreseen what kind of answer to their demand Mr. Gladstone was likely to make.

But they were playing for great stakes and risks had to be taken. Nor, in these high matters, do personal sympathies or antipathies count for so much as in private life. No Minister has ever been able to indulge his partialities to the full, or to surround himself with colleagues all of whom were his personal friends. Mr. Gladstone, more than most men, was able to free himself from influences of this kind and 
to hold the scales even. His personal attachments were not strong. And he knew-none better-the inroads which even then, four years before Democracy captured the electorate and became the ruling force and absolute majority, Radicalism had made upon that historical Liberalism of which Mr. Gladstone was the greatest, and also the most conservative, leader.

For these and other sufficient reasons Mr. Gladstone did ultimately accede to the audacious proposal which he rightly described in the terms I have quoted above. He made Mr. Chamberlain, who had never held Parliamentary office, President of the Board of Trade, and Sir Charles Dilke Under-Secretary for Foreign Affairs. The very audacity of the coup had won. It was not from Dilke, and of course not from Mr. Chamberlain, that I heard in full what Mr. Gladstone had said; but long after, from one who knew equally well what had passed at this interview. From Dilke I heard, that afternoon and later, many things which I do not repeat. I desire to give only the essential facts, and only those which concern Mr. Chamberlain, in order that it may be seen by what methods-by what violence indeed-these twin heirs of Danton forced open a door which the most powerful, and certainly the most autocratic, Minister of his time had closed.

As I recall the scene of that afternoon in Dilke's study, Mr. Chamberlain's reserve was even more remarkable than Dilke's effusiveness. He was clearly surprised by the freedom of Dilke's revelations to a man whom he, Chamberlain, knew only or mainly as a journalist. He had not perhaps at that time understood that a journalist may be, and often is, the most discreet of mankind. He knew little or nothing of $T$ he $T$ ribune or of its high traditions, or 


\section{I4 ANGLO-AMERICAN MEMORIES}

what it expected of a representative to whom it had enstrusted a responsible post. He thought Dilke rash, and he certainly had no part in his friend's indiscretions, if indiscretions they were.

There he sat; silent, a little puzzled, a good deal a mused, perhaps a little alarmed. He looked a Sphinx ; though he had not her composure. He smoked impatiently; the puffs from his cigar expressing well enough the perturbations of his mind, the uneasiness of the position in which he found himself. True, he was aware that Dilke and I were friends, but he may well enough have thought that it was not wise to choose a journalist as friend, and to pour out to him the secrets of a political crisis; for such it was to him and to Dilke.

It was a crisis in their fortunes and, as events proved, in the fortunes of the State. It was the real beginning of a great career. Mr. Chamberlain, no doubt, would have come to the front later, even if he had failed then; but time was then of the essence. What he wanted was a place in that Ministry; not a place in some Ministry of the future. Mr. Gladstone was expected to do great things, as he did, though not precisely the things on which he and his friends and Mr. Chamberlain himself then counted. It would have been far more difficult to force his way into the Government later, had this attempt been foiled. Above all, the history of 1885 and 1886 could not have been the same ; nor could Mr. Chamberlain's authority have sufficed to wreck the first Home Rule Bill. It was therefore the turningpoint for him. He stood upon the threshold, and no wonder he was disturbed at finding a journalist sharing these momentous confidences. No wonder he sat silent. I only wonder he did not try to silence 
Dilke. But he did not. I hope, as time went on, he was reassured. But even now I cannot help being more than interested as I see the twisted muscles of his face, as one anxiety after another distorted that austere visage. He certainly did not mean to let it be seen that he distrusted me, and I suppose he was not aware how little the expressions that swept over his face were under his control.

The truth is, Dilke at that time had not outgrown his boyishness. Whether Mr. Chamberlain was ever a boy I am not sure. He had, at any rate, lived through municipal experiences which, in one sense, aged him prematurely. Municipal politics, even when handled by a man of genius-a quality which none would now deny to Mr. Chamberlain-do not tend to liberalize a man's mind. They sharpen it, and perhaps harden it, and certainly sometimes narrow it. In Mr. Chamberlain they never did; or, if they did, he grew broad again, and large, and all the rest of his life took ever larger and larger views, till he became the consummate Imperialist statesman of whom there is still so much to be said.

\section{III}

Thus far I have written of Mr. Chamberlain chiefly as orator and debater; a master of words. If he had been only that, and nothing more, his name would not have meant to England what it still means after five years of eclipse. What he has said has often been admirable, but it is what he has done that has given him his unique place with the English people. I will try to sum up in sentences 
some of his achievements, and I begin with one which may commend him to people who set a high value on what they call practical politics.

$\mathrm{He}$ is the best electioneering agent ever known in England. I don't refer now to those speeches on the platform by which he converted to his own views great multitudes of voters. I mean that he had no equal in devising and handling election machinery. He founded, I believe-at any rate he developed-the National Liberal Federation, a superior kind of caucus and a vast improvement on the American caucus which was supposed to have served, but did not, as its model. He established a permanent control over Birmingham. He extended that control through the Midlands, rescued great constituencies from his opponents, kept what he recovered, and the Midlands are still his. First Liberal and then Unionist victories throughout England were due in the first instance to him and his power of organizing political forces.

He defeated Home Rule in $\mathbf{1} 886$ and again in I893. In both cases he had powerful allies, but in neither is it probable that without him either of Mr. Gladstone's Home Rule Bills could have been beaten. The best testimony I ever heard to Mr. Chamberlain's firmness came from Lord Randolph Churchill. Lord Randolph said :

"Mr. Gladstone offered such concessions to $\mathrm{Mr}$. Chamberlain that I never understood how he could reject them. I should have given in. And I should have wrecked the great cause which Joe saved."

"Joe" is the name given him by both friends and enemies; a name of affection; and of hatred that tried to be contemptuous and failed.

He was the first Englishman to conceive, adopt, 
and carry through that wise colonial policy which has made the great Colonies at the same time independent and loyal. As Secretary of State for the Colonies from 1895 to 1903 he gave effect to the Imperial idea which underlay all his dealings with the Colonies. In proportion as their control over their own affairs became complete, their relations to the Mother Country became closer. They became, in a new sense, integral parts of the British Empire. They ceased to be Colonies and became Commonwealths or Dominions. A momentous change. It was Mr. Chamberlain's work. He planted and he watered, and the ripening harvest of to-day when these great States meet in Imperial Conference in London, the Prime Minister of Great Britain presiding, and debate great questions of Imperial concern on even terms, is "Joe's" harvest. Ask Canada, in the pride of her Dominion, what she thinks of Mr. Chamberlain. Ask Australia, now a Commonwealth. Ask whom you will. I take it no name stands higher, no Englishman is recognized as a greater benefactor.

I can think of but one man who has done a work comparable to Mr. Chamberlain's, and that is Cecil Rhodes; not in South Africa only, for the example and inspiration of Cecil Rhodes were far-reaching. The two men wrought together; equal partners in the great enterprise of Empire-building. It has been the fashion to say that Chamberlain brought on the South African War. I have denied that more than once, on the authority of the late Duke of Devonshire :

"It was no more Joe's war than it was my war. We were all of one mind. It was the Ministry's war." 
And it had to be fought if the Empire was not to go to pieces. Kruger and the Kaiser between them would have turned all South and Central Africa into a German principality.

He was the first Englishman thoroughly to free his mind from the worn-out fetish of Free Trade; to adopt for himself, and, after years of struggle, to force upon the Unionist party, a policy of Tariff Reform. Of all his acts this was probably the boldest. You must have lived long in England before you can feel, even imperfectly, the hold which the superstitions of Free Trade still have upon the English mind ; or measure the effort still needed to emancipate not merely the multitude but the leaders of the multitude from their slavery to the economic fallacies which Cobden taught. The struggle is not over; victory hangs in the balance; issues even greater have delayed its coming; the leader of this movement for free thought about Free Trade is stricken by the wayside ; but he has never doubted that Tariff Reform will triumph. In that world-wide war of Tariffs, which is the greatest of modern wars, England is not for ever to stand, alone of all great powers, defenceless. When she arms herself with the weapons by which only a great economic battle can be fought, she will owe them to Mr. Chamberlain. Alone among great Englishmen, or for a long time alone, he looked across the Atlantic, learned the lesson of Protection, and Prosperity the child of Protection in America, and taught it to his countrymen. He converted his own party, and, if he did not convert, coerced the leader of his party. When that party recovers its majority in the country and in Parliament, it will be a majority for Protection.

On a question more vital still, Mr. Chamberlain's 
five years of retirement have meant disaster to England. Think what the history of these recent years might have been had he been in the full vigour of his powers. His leadership, his voice on the platform, his consummate skill in elections, have carried the kingdom with him before now, and might have carried it again. The Budget of 1909, the Parliament Bill of I9I I-is it certain that either could have become law had Chamberlain been in the House to fight the good fight against both?

Mr. Balfour-yes, Mr. Balfour is a man with a high order of political genius. Like Lord Rosebery, he is a diplomatist, skilled in every art of evading or compromising great issues; a great debater and much else. But he is not a man whom men follow instinctively, inevitably, because they must. There is no must. He asks you to choose. He appeals to reason; he philosophizes; he thinks men are led by the subtleties of a metaphysical argument. What they are led by is a trumpet note, such as you used to hear from Mr. Chamberlain, and before him from Lord Palmerston, and before Palmerston-but I will come to that presently. Mr. Balfour understands logic, Mr. Chamberlain understands men. The unhappy peers who are asked to choose between the executioner and suicide are, after all, men. They are loyal to ideas centuries old. Huxley said :

"I am a plebeian, and I stand by my order."

May not even a duke say:

"I am an aristocrat, and I stand by my order"?

Plebeian or aristocrat, the cry comes from the heart of a man, and that is what Mr. Chamberlain would have seen. Byron's line is on the lips of many an Englishman :

Oh, for one hour of blind old Dandolo ! 
The longing of the country for Mr. Chamberlain, as the one man who could deal with the crisis of today, is perhaps the best tribute ever offered him.

"Think imperially." That is one of Mr. Chamberlain's phrases, perhaps the finest of all in its simplicity and in its breadth. There was no counsel of which England stood in greater need; none which condensed into two words a purpose more vital. He has always had that art. He could always put into a phrase, sometimes into a word, a policy meant to encircle the globe. If you think it an easy thing to do, try it. But you must first have the policy. In politics, as elsewhere, the influence of an idea, of a policy based on an idea and not on expedience, is, in Emerson's phrase, mathematically measurable by its depth of thought.

Ving great moments his has been the voice of England. I will ask you to recall the hour when, alone among public men of the first rank, he took up the German challenge, which long had echoed through Europe as well as England. He spoke as no other man had spoken, of German arrogance, of German hostility to England-a considered hostility with a clear purpose, in the Press, in the Reichstag, and in the Imperial Court-of the constant German menace to the peace of Europe; of the peril that lay half hid in Imperial purposes. Prince Bülow, then Chancellor of the Empire, undertook to answer him, to rebuke him, to denounce him as a mischief-maker between two friendly peoples. Mr. Chamberlain, then a Minister of the Crown, replied to Prince Bülow from his place in Parliament thus :

"What I have said, I have said. I have nothing to retract, nothing to defend, nothing to explain. I have no wish to read a lesson to the Chancellor of 
the German Empire, nor will I accept any at his hands. What I thought it my duty to say may well have been unpleasing to him and to his master, and perhaps to the German people. But as I read English history I know of no English Minister who has served his Sovereign and his country loyally and at the same time found means to be popular abroad."

Since Chatham, who has uttered sentences like those? Who has spoken in that spirit? Who has put diplomacy behind him, and told sixty millions of a more or less hostile people the plain truth in plain words? It was the day of bitter party strife and of deep divisions between not only parties but classes : and Mr. Chamberlain was the Minister most hated by his political opponents. But to this retort to the Imperial Chancellor all England said Amen. Nor did Prince Bülow carry the contest further. $\mathrm{He}$ had no answer but silence. Mr. Chamberlain's assertion of the dignity of England and of the independence of a Minister of the Crown lives in the memory of the English people, and will long live.

It is a thing said once for all and for all time; the final word in a great dispute; the final denial of an arrogant German claim. The great Minister who said it established once for all, as I believe the world thinks, his claim to the gratitude and affection of the people in whose name it was said. 


\section{CHAPTER II}

\section{THE EIGHTH DUKE OF DEVONSHIRE}

\section{I}

I ONDON has one more statue, not much better $\mathcal{L}$ or worse than most of those which present themselves to the beholder as illustrations of that genius for sculpture which at present resides and for some time past has resided in the British breast. The art merit of these productions matters the less since both artist and beholder seem content with them. But let us not look at it like the Philistines most of us are with respect to art. Let us rather say that what really matters is that there should be a memorial of some sort, good or bad, to the great men of the nation or to the men who have done high service to the State.

This latest testimony of public gratitude is to the eighth Duke of Devonshire, who died in 1908 after a life of devotion to the highest interests of the kingdom and of the British people; a devotion than which none in our time has been nobler. It is thought a sufficient eulogy to record on that surface of the plinth which looks to the Horse Guards his name and the dates of his birth and death. It is sufficient. From 1833, or rather from early manhood to 1908 , he was, I think, absolutely the most disinterested and one of the most useful public servants who lived during any part of those seventy-five years. 
It cannot be denied that he was a Duke. If, as sundry Radicals now profess to think, the inherited possession of that title and of a great fortune outweighs and neutralizes all personal merits, there is no more to be said. But that has not yet come to be a general opinion. And even if it had, during the larger part of his life the late Duke was no Duke, but bore the courtesy title, Marquis of Hartington; or in common speech, Lord Hartington; and, perhaps still more often, just Hartington. Let that serve in mitigation of his later misfortune when upon the death of his father, in r89I, the dukedom descended upon him.

No doubt he would be classed during the whole of his life by Mr. Lloyd George among the idle rich. But it was a kind of idleness which, to men who have less time to spare for invective than the present Chancellor of the Exchequer has, would seem arduous. I was with him once when he was out of office, sitting at his writing-table, strewn with papers-masses of papers-and I said:

"You seem to find something to do, though you are no longer Minister of War."

"Yes, there's always something. The business of the estate and my other private affairs would alone keep me at my desk from ten in the morning to four in the afternoon, every day in the year."

The heads of the biggest houses in the City don't much exceed that; England being, as we all know, a country where business is transacted with deliberation, and the meaning of the word hustle is unknown.

Yet there was no man who liked better to amuse himself. He liked the Turf, on which he was singularly unsuccessful ; liked sport of many kinds, in none of which was he extraordinarily expert ; liked cards, 
which he played with skill and, above all, with judgment; and liked certain forms of society and social life. He was supposed, as every man in public life is supposed, to be ambitious. But if ambition came to him it came late; nor did it, in the vulgar sense, ever come. Is a man ambitious who twice, from purely public motives, refuses an offered Prime Ministership ? It was not his habit to talk about himself, but he sometimes let fall a sentence which was illuminative. We had been dining at the same house, and after dinner drove together in a hansomin those happy days, consule Planco, when the hansom was still what Disraeli called it, the gondola of London -to the Gaiety Theatre. I said I thought he was to have spoken that evening in Lancashire.

"No, it has been put off till next week."

"You will have a great meeting."

"I dare say. But if you knew how it all bores me."

There came a time when it bored him much less, or not at all, whether in the House of Commons or on the platform, but at all times he made his speech with the same fidelity. He did as well as he could. Few men ever served a longer apprenticeship to oratory, yet never, in the larger sense of the word, did he become an orator. I heard him from time to time, at all periods of his career. He had no natural gift of fluent discourse, nor perhaps ever understood what rhetoric meant. But he had something to say and a resolute purpose to say it as well as he knew how. In time, and with untiring practice, his sentences grew clear and strong, and became the adequate expression of the man's thought and will. If it was not oratory it was perhaps something better ; a speech of absolute sincerity. No man ever suspected him of saying what he did not think and believe and 
intend. He was, until very late, a better administrator than orator, and better in the Cabinet o: in private council than as either Minister or Head of a Department.

I will say this. I have never known a man in whom the sense of justice was stronger than in Lord Hartington. It put him, as it were, under compulsion to do justice, the most complete justice, to the men or the man whom he disliked. I will give one instance out of many. Goldwin Smith, in his Reminiseercesa disappointing pet entrancing bool-puts the crown to his long diatribe against Mr. Chamberlain by saying that Mr. Chambetlain brought on the Boer War. Mr. Goldwin Smith, it is quite true, only expresses, or echoes, what was at the time a general belief or impression. That it was also Mr. Goldwin Smith's private conriction I don't doubt. He was incapable. even in his not infrequent hours of bitterness, of saying what he did not believe. But, like Mr. Gladstone, he could convince himseli of anything; as Mr. Forster told his late leader to his face in the House of Commons. At the time when this rumour was rife, and the Radicals were trying to make Mr. Chamberlain a scapegoat, I met Lord Hartington one erening at a club and we dined together. He was then Lord President of the Council in Mr. Balfour's Cabinet, Mr. Chamberlain being Secretary of State for the Colonies. After a while he began talking about the Boer War, with what I thought an unusual unreserve. He said:

"In a sense it is not our war at all. It was forced upon us. I don't know what you think about it, but we are in truth fighting in South Africa for the Empire. If we lose South Africa, who can say what we shall keep ?" 
"Yes, I think people are beginning to see that, and that is one reason why your disasters stir English feeling so deeply. But you used the phrase 'our war.' Many men call it 'Chamberlain's war.',"

"It is no more Chamberlain's war than it is mine. When I say ' our war,' I mean it of the whole Cabinet. We were all agreed at the beginning. We are all agreed now. It is "our war.'",

"May I repeat that?"

"You may repeat what I said first, that it is no more Chamberlain's war than it is mine. But, of course, I must not commit or compromise my colleagues. It will be known later, when the war is over, that the Cabinet were of one mind. But I am quite ready to take my share of the responsibility."

As it did become known, and as the war ended in victories which consolidated not only South Africa, but the other great Dominions, and the Empire itself, I think I may now give the whole of Lord Hartington's testimony. I need only point out that at the time when he thus put himself by Mr. Chamberlain's side the war was unpopular because ill-understood and because success seemed doubtful. The Imperial purpose of it was obscured. It was not clearly seen to be a defensive war, as it was, and sentimental clamours rang through the land, and the apostles of peace and of a Little England were loud-mouthed. It needed a man to face all that.

Lord Hartington, it is true, belonged not only to the governing class, but to one of the great governing families of England. I doubt whether popular clamours, sentimental or otherwise, disturbed him. He knew very well that he had fallen upon times when the centre of political power had shifted, and that a majority of the electorate was democratic. But he 
knew that the inevitable had happened, and that the game had to be played, if at all, under these new conditions. He accepted them, but his courage in the presence of overwhelming hostile majorities was never shaken. When the Khaki election and a new lease of power to the Unionists came, it came as a vindication of his judgment. Testimony to his courage he needed none.

The office of Lord President of the Council, which the Duke then held, is supposed to be, and sometimes is, chiefly ornamental. It is coveted for the sake of the dignity and for the sake of the social precedence it gives. It had, in the Duke of Devonshire's case, a very different significance; as it has had in some other cases. It is a convenient position for a man who no longer cares to be burdened with Departmental duties. It is equally convenient for the Prime Minister to have a post at his disposal splendid enough to tempt a man whose presence in the Cabinet is desirable for personal reasons. The Duke lent to Mr. Balfour's Ministry a great name. He had had immense experience. He had a mature, sagacious judgment. He had, in a degree possessed by nobody else after Lord Salisbury's death, the confidence of the country. That it was which made his declaration about Mr. Chamberlain, and his readiness to share the responsibility for the Boer War, invaluable.

Character-what else is there? Lord Hartington sometimes made a bold use of the authority which character gave him. In that strange dispute which lay at the bottom of the quarrel between the Prince of Wales (Edward VII) and Lord Randolph Churchill, Lord Hartington was asked to intervene. Into the details I had rather not go, known though they are to many persons in London. But the happiness and 
reputation of two great families were involved, and there were compromising letters which one party to the quarrel threatened to divulge. When Lord Hartington was appealed to he said he could do nothing unless he saw the letters. They were brought and put into his hands. He read them. Then :

"Are there any more?"

"No."

"I have your authority to make such use of these letters as I think best ?"

"Yes."

Whereupon Lord Hartington walked to the fire, put the letters into the blazing grate, saw them burn to ashes, and said :

"I do not think it will be necessary to carry this matter further."

And to a protest he replied :

"You are at liberty to say what you like and do what you like. I have acted in what I consider to be the interests of both sides."

Naturally, there are more versions than one of this incident, but the one I give I believe to be the true one. Said one of those present :

"Hartington is the only man I know who could have done it without question. But that is because he is Hartington."

\section{II}

The last time I saw the late Duke of Devonshire, or rather the last time I had a talk with him of any length, was in the summer of 1907, at Devonshire House. I had met him just before at Ascot and he 
had begun discussing an international matter of importance. After a few sentences he stopped, saying with a laugh :

"This is hardly the place for a talk on such a question. Look in some morning next week and then we can go over the whole business."

When I looked in he was in his room at the northwest angle of Devonshire House, commanding the gardens and grounds, which are perhaps the finest in London, and all the finer because the grounds about Lansdowne House seem to be part of them; which they are not. The room is one of the largest, if not the largest, in Devonshire House; a palace which its architect chose to subdivide in a way that diminishes the sense of spaciousness you expect in a house of this kind. His writing-table faced the north windows. Some of the best pictures are here. There are books; there is, all over the room, the air of being lived in. To the right of the large desk was a table covered with cigar and cigarette cases, perhaps thirty in all; mostly gifts, I should guess, arranged with a precision of which only a servant would be capable, and presumably not in daily use.

The clear north light-for even in London the air is sometimes clear-fell on his face. The Cavendishes are of a type which is their own. The present Duke, a son of the late Duke's brother, Lord Edward Cavendish, is the lesser image of his uncle as he was earlier in life. At seventy-three or seventy-four, after half a century of responsibilities and labours, the late Duke had a look of power, and those lines of patient thought which belonged to his age. But the features were not much changed. The rather high, cliff-like forehead, the blue eyes, tired from over-use, the straight nose largely moulded, the mouth with the Bourbon 
under-lip, the square angle of the chin, were very much what they had been. With all its regularities of feature and proportion, the face was not beautiful. It was something much better. It had strength and faith and the stamp of that genuineness which penetrated and saturated his whole nature. It mirrored his mind. When struggling with a thought he could not express as he wished, the lips from which the words ought to have flowed grew twisted and rigid. He looked at you as if to give him the missing word, but he would not have it unless it fitted exactly. He had never been fluent, but his lack of fluency never embarrassed him, as the too familiar story of his yawning in the middle of one of his own speeches attests.

He had always been in the habit of reading in bed at all hours of the night, whether from sleeplessness or caprice. When his doctor told him it would injure the eyes, he said : "Yes, but I can't lie awake and do nothing." And when asked if the eyes did not pain him he again said : "Yes, but it is a choice of evils." His was, in truth, a stubborn nature, self-willed, impatient of advice, even when it came from his doctor. His hair and full, close-cut beard, light brown to begin with, had turned grey of late years, and the hair tumbled about his forehead. It always seemed to those about him that as the end drew near he faced death with a tranquil, almost defiant courage; with a fortitude that never failed. He had lived his life, the whole of it, and on all sides. That morning he uttered one sentence, and one only, which sounded like an allusion to the near future. We were speaking of what was likely to be the end of a certain controversy. "Yes," he said, "but I shall not see it." Nor did he. 
Concerning the subject we discussed, he said :

"I think it will be convenient if you will state your whole case from your American point of view. As you know, it has never come before me officially."

As the subject was important, he put his mind to it. He asked questions as I went on. Sometimes I had to repeat a statement. Sometimes he made a comment : brief, weighty, penetrating. No question of high policy could be wholly strange to him after forty years of experience in statecraft. Now, as before, it struck me that he never, like Boswell's Johnson, talked for victory; he wanted to get at the truth and to convince himself what was best for his own country. He had been brought up in a school certain to hold a view adverse to our American view on this topic. That to him was only a reason for taking the more pains to understand the unfamiliar view, and to make out, if he could, how the two hostile views were to be reconciled, or whether there was a basis for compromise. Never contentious, he had immovable convictions; a safeguard against contention.

Mr. Lowe or somebody else said of Lord Hartington that what he liked about him was his "you-be-damnedness." The phrase is expressive, but conveys a wrong impression. All Mr. Lowe meant was that Lord Hartington had an uncompromising independence of nature and a mind of such fibre that it yielded no assent-still less obedience-to mere authority. His attitude to other men or other opinions was not an attitude of contempt. Contempt comes cheap, and is worth no more than it costs. What he really had was patience of mind. He listened with patience to opinions he could not possibly share. He had not only the politeness which goes with long descent and great place, but a real desire to find out what were 


\section{2

the reasons which induced a man to hold such opinions. If it were an unfamiliar set of facts, he was in a similar mood. He would not give judgment until he had mastered the facts and knew both sides.

All this and much more came out as we sat there for some two hours of that pleasant July morning, the sunshine playing with the shadows on the lawn. You saw that here was a man with his mind long since made up, yet willing to reopen it if cause were shown. I thought of 1886 and of those interviews between Mr. Gladstone and Lord Hartington, when Mr. Gladstone strove to convert his colleague to Home Rule. Unlike Lord Spencer- "If you had ever been half an hour alone in a room with Mr. Gladstone you would know why I gave in "-Lord Hartington was under no spell. He knew very well that no matter what arguments his leader used, he should never arrive at his conclusions, nor ever be party to a scheme for breaking the United Kingdom of Great Britain and Ireland into fragments. He listened, but never for a moment was his conviction shaken. Against that rock the floods of Mr. Gladstone's eloquence beat in vain.

In the subjects we considered at Devonshire House I was a good deal interested, but while this talk lasted I was at least as much interested in the man with whom I talked. His sincerity of character I kneweverybody knew; but what he showed now was above all things a sincerity of mind. He had an intellectual honesty comparable to his honesty of nature. The arts of debate he put aside. There was nothing Parliamentary in his method. The arts of the advocate he disdained. There was nothing either in his method or in the man himself which you could call forensic. He opened his mind to you with perfect frankness. The tricks of the Socratic dialogue were not his. 
He had not, perhaps, the subtlety which that process requires, but he certainly had a preference for simplicity and loyalty which made it impossible to him to lay traps for an opponent or to contrive an ambush for an enemy. He met you, if at all, in the open field, on even terms.

That is what he had done all his life; a life crowded with public and private interests; temptations of one kind or another lying in wait for him at every step. Not once had he yielded. Not once had he swerved from the straight, hard line of truth and honour and honourable conduct. The bronze statue of him in Whitehall is not more erect, unbending, self-poised than was he. You would know it afar off if only from the up-springing carriage of the head; unconscious in Hartington himself, but patrician.

He was no more afraid to defend his own interests than those of the State; when the two happened to coincide. He resisted Harcourt's Death Duties in I 894 on both grounds. He gave Chatsworth as an illustration. The Dukes of Devonshire had kept up that place partly for the public, partly for the tenants and neighbours, as well as for themselves. They had put a great share of their revenue back into the land. They had given yearly great sums. Said Lord Hartington then, in substance :

"You cannot have it both ways. If you exact from us by law what we have given of our free will we shall obey the law, but we shall no longer have the means to bestow in charity what we have bestowed heretofore; or what the law now takes from us."

He was much criticized. The Radicals raged, after their manner. But who does not now see that he was right? The people who own no land and wish to make land bear all its own burdens and theirs besides, 


\section{ANGLO-AMERICAN MEMORIES}

do not see, and will not see. The Dukes of Devonshire own a considerable Irish property, Lismore. Said the late Duke-I do not know whether he himself ever said it publicly:

"I have had the figures examined. Within a recent period we have spent on Lismore for the benefit of the tenants $£ 34,000(\$ 170,000)$ more than we have received from it in rent."

Even with that, I suppose the single taxers and other Socialists would not be content. They want the whole. No man knows what the end will be.

It was, I believe, when these Lismore figures were quoted in the House of Commons that a Nationalist Member asked :

"How long is it since the Duke of Devonshire has been in Ireland?"

And from across the floor came the answer :

"Not since his brother was murdered in Phœnix Park."

Who said it I do not know. I wish I did. It is worthy to rank with Colonel Saunderson's answer to a demand for his reasons against Home Rule.

"There are in this House sixty-nine good and sufficient reasons against Home Rule, and there they sit!"

Our talk did not then turn on these matters, but my memories of other talks and of Lord Hartington as a steadfast advocate of the rights of all classes are many, and I choose out of them such as seem to me best to paint the man.

The American tourist who has seen Chatsworth has probably brought away with him the impression that it is all state apartments. Only that wing of the house is shown. They are of a great and impressing splendour, but those parts of the house in which the 
family live, though still splendid, are delightful and homelike. The library contains treasures known the world over. The morning-room is panelled with Titians, and I was going to say Van Dycks, but I have forgotten. The bedrooms are, or were, equally magnificent and primitive. There were no bells, but a servant in livery waited outside the door to take your orders. The dining-room is of great size and beauty. The most beautiful thing I ever saw in it was the light on the face of the late Duke's father as we sat at lunch, and Lord Hartington arrived unexpectedly, having ridden over from Hardwick Hall where he then lived. Never between father and son was there a more perfect relation than between these two. Lord Hartington once broke through his reserve to say to me :

"I owe everything to my father ; everything."

From a man whose emotions easily found their way out, that might not have meant much. From him it meant precisely what he said; and he said it as if the obligation were one he was bound to acknowledge. The burden of gratitude to his father would not be borne for ever in silence.

If, as Mr. Price Collier says, Americans do not like Englishmen, they surely would not have liked Lord Hartington. He had in the highest degree those English traits which Americans, some Americans, think un-American : the not wearing his heart on his sleeve, the absence of effusiveness, of self-assertion, of swagger in any kind. I have used some superlatives in sketching him, but I dismiss all I have said as inadequate; perhaps because of the superlatives. They always betray you. They will not do the work they are meant to. To Lord Hartington himself they would not have been agreeable. He used none. 
Delete them, then, if you will, and think of Lord Hartington as what he was, an Englishman without brilliancy, without pretence, without great original genius, without much literature or art; not a great administrator in the official sense, but a man who, never seeking it, won the confidence of his countrymen, deserved it, did high service to the State, to which his devotion was wholly unselfish. A man who was, and will remain, an example of truth, judgment, wise conduct in great affairs, and integrity never questioned. He seemed a part of the British Constitution. Were he still alive, the powerful Ministry now* seeking to overthrow the Constitution would have had to overthrow him also; which would have added something to the difficulty of their endeavour.

* Written early in 1911 . They have since succeeded; temporarily. 


\section{CHAPTER III}

\section{THE LATE DUCHESS OF DEVONSHIRE}

ONCE or twice in a generation appears a woman who takes command of the social world in which she lives. Lady Jersey was such a woman. Lady Palmerston was another. They are historical instances. The late Duchess of Devonshire was a third; and not the least remarkable of the three. To round out a career like any one of these there must be something more than character or exceptional gifts. There must be opportunity, and circumstances must combine with fortune. They did in the late Duchess's case, but rather late in life; yet I cannot remember a time when she was not a great power in London.

Whether her foreign birth was against her I know not. London has a great power of assimilation. It has adopted many a woman not of English blood into that charmed and sometimes charming circle known as Society. With German Kings and Queens to rule over them and an army of their kin encamped in Mayfair, why should there be any hesitation about the social naturalization of the alien? There is none, in one sense. There is only a process of selection. Of the American women who have married English husbands, some have been taken and others left, but, on the whole, the American record is a good one. We perhaps think it a tribute to the charm of the American 
woman, as it is, though churlish patriots at home take a view different from that. But we do not always stop to think how many wives of English husbands are neither English nor American.

The great lady who died on the 15 th of this month* was the daughter of Charles Francis Victor, Count von Alten, a Hanoverian nobleman. From her girlhood she had a renown for beauty. She was an ornament of the Court of King George $V$ of Hanover : who never saw her, poor blind King that he was. Born, they say, in I 832 , but that has always been disputed. There has always been a question how old she was; partly because she was so long young. What is certain is that in 1852 she married Lord Mandeville, son and heir to the sixth Duke of Manchester. It was not supposed to be a pre-eminently fortunate alliance. There was an ancestor, an Earl of Manchester, who was one of Cromwell's generals, and a good one, as he proved at the battle of Marston Moor and elsewhere. But when Mlle. von Alten married Lord Mandeville the possessions of the family were not precisely splendid, and the scope for Lady Mandeville's ambitions was not so wide as she desired.

But in 1855 he succeeded to the dukedom, and in I 858 the Duchess was made Mistress of the Robes: a great post about the Court. This was in Lord Derby's second administration. There was, therefore, no question about her social position, nor could it have been long before her personal qualities made themselves felt. If there was a difficulty it was finance; as everybody knew. It is a subject on which people talk more freely here than in New York. Poverty is no reproach ; it is only an inconvenience, and nothing is more common than to hear a woman in high place * July, I 9 I I. 
say bluntly she cannot "afford" what she wishes. I suppose a lady of position in New York would perish sooner than make such a confession; many such ladies, if not all; and all delectable in all other respects; as they all are.

My English memories do not go back to so early a date as this, so I will come down to a time of which I know something personally. I stop only to set down one fact which she would forgive no one for omitting; that she had three daughters who became, the first, Duchess of Hamilton ; the second, Countess of Gosford ; the third, Countess of Derby. In that way was one of the supreme ambitions of an English mother satisfied-she married her daughters well. Two of the three were great alliances. One of them has come to touch us; since it was the eldest son of Lady Gosford, Viscount Acheson, who last year married Mildred, daughter of Mr. Ridgely Carter, long Secretary of the American Embassy in London, in succession to Mr. Henry White. Mr. Carter became American Minister to Rumania : a post by no means adequate to his abilities and experience. Miss Carter was before her marriage one of the flowers of the American Colony in London, and still is ; regardless of the fiction of law which makes the American wife of an Englishman herself English.

It is a tradition that among the many who admired the Duchess of Manchester was Mr. Disraeli; a man whose admirations were discriminating. The two names were never that I heard of otherwise connected. Disraeli was not a man to be permanently attracted by beauty unless there was something more than beauty. He required of a woman that she should be able to interest him. Now the Duchess had a maxim of intercourse which ran like this: "Listen to every- 
thing ; answer nothing." Not a maxim to be acted on strictly. It is, however, true that for a woman of gifts so transcendent as hers, she talked with reserve. What she liked was to form her own estimate of character; to weigh social forces; to form conclusions and to act on them. Disraeli's was a glance which went deeper than the surface. He, too, had a gift of silence. But two silences beget speech. The genius of the man and the genius of the woman had much in common: and though neither might care for mere talk with an unsympathetic listener they knew each other when they met; they had an intellectual kinship; and they had each something to give in exchange.

But the man about whom her life revolved was neither Mr. Disraeli nor her first husband, the seventh Duke of Manchester. It was Lord Hartington. Theirs was a friendship which began long before the Duke of Manchester died : and lasted to the end. It was the deciding fact in the lives of both. The attachment between them was of the strongest, and never diminished. It was said that Lord Hartington would never marry unless he could marry the Duchess of Manchester. He never did. As soon as might be after the death of the Duke of Manchester Lord Hartington, being then Duke of Devonshire, took the Duchess to wife: while people were still guessing.

But there had long been between them a tie wholly independent of mere marriage. By nature Hartington was indolent; averse from politics and public affairs; without political ambition. The Duchess used all her influence all the time to rouse him from this lethargy, and to fill his mind with visions of a great future of great service to his country. She succeeded, and, having succeeded, never allowed him to relapse 
into a mood of indifference. England owes to her an immense debt; for the kind of usefulness there was in Hartington belonged to him alone. Her ambition was to see him Prime Minister. She ought to have been, but I think was not, more than content when, alone among all men like him, he had the opportunity twice to refuse, and did twice refuse, that great office. But no guidance could have been more delicate than hers; whether in his relations with great affairs or in other matters which required perhaps an even finer touch. In all these she had and used consummate skill. She never used bit or spur. She rode with light hands and a loose rein. Of other attachments she was never-or never showed herselfjealous. London, always cynical in such matters, used to say she encouraged them, and used them to confirm her own authority. It is for women to say whether that could have been.

$\mathrm{He}$ rewarded her with a devotion which knew no limit. She was a little older than he, but what did that matter? He was from the beginning quite careless how he showed his devotion or who knew it. Throughout their lives it was the same and shown in the same way. If you entered a drawing-room where the Duchess was, you looked about for Lord Hartington. If he was not near her you looked at the door, and you would not look long before you saw him enter. His greeting to his hostess accomplished, he hardly noticed others. He was quite happy to stand in a throng and gaze on the Duchess from a distance. The heavy Cavendish face lighted up. With all his immobility of feature you saw happiness in his eyes. When he had found his way to her side, they might or might not have much to say to each other. But speech was not needed. Presence was enough. 
Affinity is a worn-out word, but if ever there was an affinity between a strong man and a woman with both beauty and cleverness this was one.

If the Duchess was tolerant she was not always tolerant. I knew of a case. A much younger and therefore lovelier woman was their guest. It befell that this young woman and the Duke wandered away together one afternoon and returned after dusk. Said the Duchess to the younger woman :

"My dear, I'm delighted you and Hartington should be friends, but you will not again be out with him so long or so late."

That is a good enough example of the tone she took with all sorts of people when things were not going to her mind. She was a law unto all her world. A guest asked for Monday did not arrive till the Thursday : having telegraphed to excuse herself. She was met by the Duchess brandishing the telegram :

"This is your wire; answer prepaid. Did you think I was too poor to pay for my own message ?"

And for three days this temper continued. At the end of the three days, the Duchess said:

"My dear, you deserved your punishment and you have had it. I love to have you here, but when you say you will come I expect you to come."

After which all smiles and sunshine.

Implacable she certainly was; often unforgiving; sometimes vindictive. A lady whose position entitled her, you would have thought, to be independent, told me the story of a quarrel between the Duchess and herself. The Duchess had been overbearing and was in the wrong, but my friend had not the less surrendered. I asked :

"Why did you give in ?"

"Do you suppose I was going to make an enemy 
of the most dangerous woman in London, and the most powerful ?"

So the doctrine of worldly prudence prevailed.

When the Duchess gave her wonderful fancy ball in I 897 in honour of the Great Queen's second Jubilee, she asked eight hundred people and closed the list. One of the unasked persuaded her Ambassador to intercede with the Duchess. She refused. He reported the refusal to his countrywoman; who replied :

"You must go back to the Duchess. If I am not asked to this ball my position in Paris, in St. Petersburg, in Vienna, will be ruined. My social future is in your hands."

The Ambassador returned and renewed his entreaty.

"Why do you bother me? You know I never ask any one not on my original list."

"Duchess, I have left Mme. X. in convulsions on the floor of the Embassy drawing-room. If you do not send her a card I will not answer for the consequences."

"I will not send her a card."

Then a pause; then :

"If she likes to come without a card she may come." And she came.

This is not the Duchess's most amiable side, but you must look at her on all sides. She was never a woman to reign and not govern. But when she chose to be charming she could be more charming than anybody. When she talked, her German accent was marked, but her mind was English. She had unexpected felicities of diction; in little matters and great. After an absence in America of some years I met her again at a friend's house in London. There was a look on her face which I thought inquiring, and I said : 


\section{ANGLO-AMERICAN MEMORIES}

"I am a ghost."

"Well, you look a prosperous ghost."

She loved the turf and cards, and loved to win at all games. But for Hartington she might have thought life only a game, but her love and ambition for him gave her a great and serious purpose, which she put above everything. After his death she clung to his memory and lived in that. You might, after that great disaster, have expected her to quote Landor :

I warmed both hands against the fire of life;

It sinks and I am ready to depart.

But it may be doubted whether, even at seventynine, she was ready to depart. She would rather have said with Huxley: "Death, the everlasting extinction of one's energies and faculties, is horrible and incredible." But that despairing protest has never yet availed. 


\title{
CHAPTER IV
}

\author{
MR. BALFOUR
}

I

CONCERNING Mr. Balfour's resignation of the Conservative leadership there are two or three things to be said before even those personal memories which are my real subject. This, first of all, that the one great act of decision in his public life is an act of suicide. Secondly, that he has led the Conservative Party during all these recent crises with an excess of prudence; led it with less courage and foresight than were desirable; led it often into the by-paths of politics when a broad, straight road lay plain before him. Nevertheless, his retirement, if it be indeed a withdrawal and not a fausse sortie, is a calamity the disastrous consequences of which are immeasurable.

Irresolute as he has been, there is no one to replace him. Mr. Bonar Law is an able man of business, with a great knowledge of fiscal and economical questions, but with little experience of Parliament and none at all of leadership. He becomes leader at a moment when all the resources of the most experienced Parliamentarian will be needed to fight Home Rule and other measures of Revolution, imminent in the House of Commons; and Mr. Law has none of them. He may acquire them all, but not all at once. Mr. Balfour has them all, and in the most critical hour of his party's life resigns. He delivers over his party and his cause, with the Union of the three kingdoms at 
issue. It is not, of course, a betrayal, but it is a surrender. Still, any leader is better than none, and for most Parliamentary purposes Mr. Balfour has no superior and no equal. Mr. Asquith, in words which do him honour and are but a just tribute to his only rival and only superior, described him as the most distinguished member of the greatest deliberative body in the world. If it is no longer the greatest deliberative body in the world it is because Mr. Asquith has substituted the gag and the guillotine for deliberation, and the closure stifles debate. Reason the more, since the situation is more difficult, why Mr. Balfour should have stood by his party. If ever he had had in him the real spirit of leadership this is the last moment he would have chosen to desert. But he has in him all the gifts a leader ought to have except the gift of leadership.

That he has had every provocation must be admitted, but is he the first party chief whose followers have been disloyal or mutinous? His business was to coerce them, to lead and not be led, to sacrifice every personal feeling, no matter how just, to the party and the cause.

Mr. Balfour himself put forward the excuse of health. He told some of his friends some months before he resigned that he was too ill to go on. I should never dream of questioning any statement Mr. Balfour made. Let it then be admitted that health had something to do with his retirement. It adds to the regret which all but his opponents feel, and some even of them. But I suppose it may still be said that if there had been no other reason, this alone might not have sufficed. His ill-health has been borne for years. Alone, it might have been borne for years to come. 
But as I have begun on this uncongenial subject I will go a little way into the inner history of it and say what I believe to be the true, original, and perhaps final cause of his decision.

A woman is the cause. Not in the usual sense, but in the sense that a woman has led the attack on him, and that, but for her, the cabal against Mr. Balfour might never have grown strong enough to drive him from his post. No opposition has been more damaging to him than the opposition of $\mathcal{T}$ he Morning Post, and The Morning Post is Lady Bathurst. I dislike to mention her name, but how otherwise can the truth be told? The Countess Bathurst is the daughter of Lord Glenesk, who was Sir Algernon Borthwick and a journalist of unexampled genius. He made this paper the great power it is, and bequeathed it to his daughter. Lady Bathurst does not, of course, edit or manage it, but she controls it, and is absolute master there when she chooses to be. If any woman were equal to such a duty she would be equal. A woman of rare qualities, with a capacity for great things which all men who know her acknowledge and admire, as they do her charm of character. But she is a woman, with a woman's impulses and emotions, and with the readiness of a woman to be governed, and to govern other people, by impulses and emotions; and she intervened in grave affairs, which are essentially the affairs of men and not of women.

There were other causes than the one on which I have dwelt. It is not necessary to distribute these responsibilities mathematically. But it is safe to say that the unrelenting antagonism of a journal so powerful as the one which Lady Bathurst owns and sometimes directs was enough to turn the scale. 
Early in the agitation for Tariff Reform she became a convinced Tariff Reformer; and convinced that Tariff Reform was the one paramount issue of politics. Mr. Balfour's mind moved slowly on that matter; or slowly toward the conversion he ultimately announced, and to his acceptance of this proposal as an article of party faith. His mind is, on most questions, subject to philosophic doubt. He was born a Free Trader. It is thought doubtful whether he ever went heartily and wholly over to the other doctrine. Certain it is that he was long in coming about; he shivered in the bleak wind of fierce controversy; and if finally he swung round on the other tack he laid his new course uncertainly. Lady Bathurst was impatient;-was there ever a woman who was not? When she wanted a thing, she wanted it, and at once. The criticisms of $\mathcal{T}$ be Morning Post on Mr. Balfour were incessant; and they took the form of reproaches, sometimes of invective, and often of rebuke. It is a great party organ and was attacking its own party leader. But for its intemperate zeal the Tariff Reform controversy need not have become envenomed, as it did, and the division in the Conservative ranks need not have yawned so wide.

But consider the dates. It was in 1903, May 15, that Mr. Chamberlain delivered in Birmingham the great speech in which he summoned the Unionist Party to declare for Tariff Reform. He was then in a position of such authority that his challenge could not be neglected or declined. At once the party, the whole body of Conservatives, made answer in one way or another. The majority accepted Mr. Chamberlain as leader on that subject, and leader on that subject he remained. When did Mr. Balfour 
announce his decision? Is the date known? The dates of several speeches could be given in which he recorded different stages of the long process which is supposed to have ended in his complete acceptance of Tariff Reform. If there be any one statement which, taken by itself, was decisive, how many years had passed before it was made? In the interval, down to I906, the leadership of the party had become in effect, though not in name, dual. Then, unhappily, Mr. Chamberlain, from reasons of health which admitted of no debate, withdrew from public life. For five years Mr. Balfour remained at his posturged on, during much of that time, by his followers -in the plenitude of his Parliamentary powers.

Then came the Parliament Bill and the momentous question whether the Conservative Peers should allow it to pass, as it was certain to do in any case, or suffer the Upper House to be swamped by Mr. Asquith's creation of five hundred Radical Peers-" chimneysweeps," as Mr. Churchill hypothetically called them. Lord Halsbury pronounced for the last ditch ; which the wits called the first ditch. He and his supporters, numbering more than one hundred votes, openly rebelled against Mr. Balfour and Lord Lansdowne. Lord Salisbury, Lord Selborne, Sir Edward Carson, Mr. George Wyndham, all bound to him by political and personal ties, openly defied him. He is supposed to have said he did not mind. Is it conceivable that he did not? Is it not more probable that he deceived himself than that he "did not mind " the defection of these and other pillars of the party and his own friends? Whether he minded it then or not, the mutiny spread, and he may well have resented it later. The Halsbury Club marked another deepening of the division in the party. That club, we are told, 
intended no disloyalty to Mr. Balfour. It was merely meant to oppose his policy, to take the control out of his hands, to reduce his leadership to a phrase. He might remain leader provided they were not expected to follow him. If Mr. Balfour meant to resign, then was the moment, but he let it pass. Why he has resigned now it may be hard to say, except that there came at last the hour when he could endure no longer.

Long before the Halsbury Club there had been criticisms on Mr. Balfour's policy or want of policy ; on his conduct of the Education Bill of 1902 ; on his failure to pass a proper Trade Union Bill, spite of advice; on his failure to bring forward a scheme of Redistribution; on his neglect of the ever more pressing question of the Reform of the House of Lords; on his disposition to "let things slide," or to follow the line of least resistance. There was disaffection at the Carlton Club as well as in the Halsbury Club. But to the Carlton Club, the head-quarters of his party, Mr. Balfour never went. His most intimate adviser, whose name everybody knows, is supposed to have thought it his duty to keep from the knowledge of his chief whatever might be disagreeable to him. He was shepherded too much. Something may be said for the Unionists who, having chosen Mr. Balfour for their leader, had to look on while so many of the functions of leadership slipped out of his hands and into the hands of a man they had not chosen. Mr. Jack Sanders's fidelity was not disputed; it was his judgment which was impugned. $\mathrm{He}$ made access to Mr. Balfour difficult, and free communication between him and his party impossible.

In the great contest over the Parliament Bill Mr. Balfour described himself as ever a House of Commons 
man. What he meant the House to understand was that in opposing the Bill designed to convert the House of Commons into a Single Chamber, he was not acting as a partisan or champion of the House of Lords. He put the Commons and their rights first. As far as it went, that is a true account, but it is very far indeed from being complete, nor can you understand Mr. Balfour if you regard him wholly, or even mainly, as a Parliamentarian. $\mathrm{He}$ will go down in history as a great member of Parliament, as Prime Minister, and much else which is purely political. But there is a Balfour behind all that, of whom the public sees little and knows little; yet, for all that, the real Balfour. If you meet him you will have glimpses of the real man, or of one or more sides of him. A single sentence will show how wide and deep is the gulf which divides him from politics. I used once, in a group of men which included Mr. Balfour, an impatient expression about the Psychical Society and its so-called investigations into the nature of psychical phenomena. He broke in at once :

"I think your scepticism carries you too far. There is nothing in political life as I know it which can be compared to the interest, the profound interest and significance, of psychical research."

Yet I am not aware that he has ever given in his adhesion to the beliefs which that society was founded to establish. It was simply that on all subjects, or on most, he has an open mind; and that to present to him a problem of any kind is to challenge his attention. And that of itself is almost enough to explain his defects as leader of a great political party. He shares with Pascal the distinction of being a devout believer, yet possessed with an invincible longing to apply 
scientific methods of inquiry to matters of faith. $\mathrm{He}$ is a saint in the skin of an agnostic. There is an intellectual and spiritual kinship between him and the great Frenchman. Of the Provincial Letters, he might have written the first four. To the imaginative height, the spiritual splendour of the rest, he could never have attained. Nor has he that genius for condensing long periods of thought into the compactness of an epigram which makes the Pensées not merely immortal, but the most fertilizing of all such collections.

Yet, in a way and to a certain extent, he is a child of Pascal all the same. If he has not Pascal's geniusand who has? - he has the Port Royalist's habit of seeing both sides, and of stating both. It is a useful habit in the realms of speculation. It is almost fatal in party politics. On a party platform or in a House of Commons debate, as in a legal trial, there is always some one else to present the other side. A Minister or a leader of the Opposition who states both only perplexes and dispirits his followers. Let him think what he likes of the other side of a question; he has no business to think aloud. But Mr. Balfour was always thinking aloud on his legs. At times he rivalled Mr. Gladstone himself in the art of applying metaphysics to politics, and of qualifying his statements, till they ceased to be statements, and became hypothetical suggestions.

During the debate on the Parliament Bill Mr. Asquith asked him across the table whether, if or when the Conservatives came back into power, they would repeal the Parliament Bill. Peel would have said, "It is my purpose." Palmerston would have answered in a word, "Yes." Disraeli would have uttered a flashing sentence: "We exist only 
for that." Even Mr. Gladstone might have declared that the logic of circumstances would impose on him that high duty. But Mr. Balfour began to distinguish. There were clauses which would have to be modified. Others, no doubt, must be expunged. If any part of the Act remained on the statute book it would not be the most mischievous part. And so on. His followers sat aghast. The ground on which they were fighting the Bill as a measure of revolution was slipping from under them as Mr. Balfour went on refining. If he had met the challenge with a "Yes, certainly we will," he might have remained leader of the party, and the blue sky that bends over England would have been a good deal bluer than it is today.

\section{II}

I hope it may still interest Americans to know that Mr. Balfour has been a steadfast friend of this country and people. He has been more than a steadfast friend. $\mathrm{He}$ had, before he was Prime Minister, and while he was Prime Minister, and has had ever since, a statesman's appreciation of the usefulness of friendship to both countries. It was while he governed the British Empire that most of the most dangerous disputes between Great Britain and the United States came up for settlement, and were settled. Venczuela had been disposed of by Lord Salisbury and Mr. Olney, but there remained the Bering fisheries, the Alaska boundary, and others, which, if less important, were almost as menacing. I know that Mr. Balfour was for the pacific adjustment of all these, and used to that end all his authority as Prime Minister. He said : 


\section{4 ANGLO-AMERICAN MEMORIES}

"The advantages of a victory in each one, or in all these, controversies, would be as nothing in comparison to the advantages of a permanent good understanding with the United States."

What he did as Prime Minister is better evidence even than what he said. But I will quote one other testimony. A well-known Unionist M.P. went to see him during one of these crises to beg him to come to terms with the United States. Mr. Balfour got out of his chair and said :

"I am as anxious for it as you are. It is the thing I care most about."

He was in truth genuinely devoted to a good understanding with the United States.

He was for arbitration where arbitration was possible; that is, where the United States Senate could be induced to agree to a treaty of arbitration. If there had to be negotiation, he was for friendly negotiation, and for reasonable concessions or compromise, as every reasonable man is, well knowing that in few international disagreements is the right all on one side. On this view he acted consistently throughout. $\mathrm{He}$ even yielded to our proposal to substitute for arbitration a commission of six for the delimitation of the Alaska boundary; nor did he object when, by way of fulfilling our pledge to appoint impartial commissioners, we named Senator Lodge and Mr. Turner. I dwell a little on this because I think we have hardly done full justice to Mr. Balfour's attitude in Anglo-American disputes; nor to $\mathrm{Mr}$. Balfour himself for his consistent good-will to the United States and his readiness to make sacrifices for the sake of Anglo-American harmony. He inherited this tradition of friendship from Lord Salisbury: from the later Lord Salisbury, who was true 
to it during all his last Premiership. To that great Prime Minister also we have yet to acknowledge our obligations in respect of Venezuela and other matters.

One other point, briefly. Mr. Balfour is the one Chief Secretary of Ireland who governed that ungovernable island. Of him as the executive officer in whose hands rested the cause of peace, of law, of order, it is to be said that he did the work he was appointed to do; and that there, in the most trying post which any man can anywhere hold, he showed great administrative qualities and great courage as well. To him also was due the new policy in respect of land which transformed the agrarian conditions, and gave prosperity to half, or more than half the island. The two together make a record. Perhaps that also may conciliate American, if not IrishAmerican, good-will.

The Mr. Balfour of private life is not, I think, very well known to his own people; and naturally still less well to us. They think of him as a being somewhat remote from those personal and domestic sympathies on which, in all their public servants, from King and Queen through all social levels, they set a high value. They know that Mr. Balfour is not married. They do not know that his own family have been and are to him in a singularly close and beautiful relation. When he is at his place in Scotland, Whittingehame (pronounced Whittengem), he is surrounded by them. He has married brothers and sisters, and they and their many children fill the great house. They are almost as much at home there as he is, and take up a great deal more room. There is, to be sure, a study which is his and his only, where he does alone his thinking and other 
kinds of work, and into which no one enters unless summoned. I don't wish to linger on private matters, but if you will ask anybody who knows the facts you will easily learn how broad is his kindliness of nature, how genuine are his affections, how farreaching is his charity, and how he is loved by his family, his friends, his neighbours, and his associates in public life.

You have heard, no doubt, of his charm of manner and character. No one who meets him is insensible to that, or fails to see that he has a true sweetness of nature. But we seem to have got into a habit of judging a man by trivialities, and when Mr. Balfour is discussed he is discussed as a devotee of a particular game on which all the world has gone mad. With the man himself you may talk long and never hear it mentioned. But you will hear of books and music and pictures, and, if you are supposed to be interested in such matters, of religious beliefs and of those psychical mysteries to which I referred in a previous letter, and of others. If you are a friend, he may talk to you of friendships, but in social gossip he has little interest, and of scandal an abhorrence. He has never sought to make his house in Carlton Gardens a social head-quarters : contenting himself with giving two or three large dinners, mostly political, during the season. That is equivalent to saying that he does not care to use social influences for the purposes of public life, as Lord Palmerston did, as his uncle, Lord Salisbury, did, as Lord Rosebery always has, and many another political chief. It has been thought that as leader, and in his own interest as leader, as well as in the interest of his party, he might do more. His London house is adequate to hospitalities on a splendid scale. In his drawing-room hang the famous 
canvases by Burne-Jones, as good examples as exist, or perhaps the best, of that artist's conception of nude beauty as seen in the natural woman, and yet imaginatively treated. But Burne-Jones and the British Philistine have never quite understood each other, and Mr. Balfour may not care to expose a master whom he loves to the criticism of the man in the street.

It may be said of Mr. Balfour that he has a mind which moves automatically. An incessant activity is its normal natural state. $\mathrm{He}$ is always ready. He said once of himself that when he went down to the House neither expecting nor prepared to take part in a debate, he made his best speeches. Partly, no doubt, because no subject is likely to come up in Parliament which he has not long since studied; and partly because, whether in speaking or writing, a man is apt to do his best under pressure. He must speak, and he must not fall below his reputation, nor below the occasion. If you want to know what kind of stuff there is in a man, take him by surprise, said Emerson. Whether taken by surprise or not, Mr. Balfour alone among the men of to-day lifts debate in the House to a higher level. Mr. Gladstone did that, and so, while he was speaking, did Mr. Bright, but both Mr. Gladstone and, in a less degree, Mr. Balfour maintained this high level. The House expects its members to conform, to take their note from the general tone of the House. But Mr. Gladstone created the atmosphere in which he moved and which the House breathed. You may still, if you are there on a great night and Mr. Balfour is up, see something of the same magical effect.

Perhaps he expects from others what he only is capable of-the power of an instant response to 
a demand, of instant brain-work at full speed ahead. I will venture on one illustration. It was after dinner at Wynyard Park, the house filled with people, most of them celebrities. I was standing with Mr. Balfour, British fashion, on the hearthrug before a lighted fire. He had heard I meant to write a book, a comparative study of English and American politics, and other matters, and asked some questions. Presently he said :

"Well, you have had great opportunities. You ought to write such a book. Have you begun it ?"

"No."

"Then go upstairs now and write the first chapter."

Alas! it was a counsel of perfection. It was what he himself would have done. But Lady Londonderry presented herself at that moment and required us to make up a bridge table, and I did not write my first chapter that night; nor have I written it since.

Whether from his philosophical studies or otherwise, he has mastered and applied the doctrine which Taine said was the result and root of all philosophy : "Take things as they come." Many years ago there was a story that he was ruined. Perhaps he used that ominous word himself; at any rate, he did say:

"They tell me I am ruined. It may be so, but I do not find that it makes any difference in my life. I still have all that I ever cared for; all that I need for the convenience and comfort of existence. Nay, I still have my friends. How can I be ruined ?" And in truth he was not ruined. It is not our business, but I believe the story grew out of a large purchase of land adjoining the Whittingehame estate, just before the drop came in land values, and this new property did not at once seem a good investment. 
For whatever reason, he was long known as Prince Arthur. Mr. Lucy, now Sir Henry Lucy, perhaps gave him that name; at any rate, he used it weekly in his sparkling "Essence of Parliament" in Punch. It was supposed to give offence in certain quarters, but there was, and is, in him and in his bearing, and in his remoteness from all that is ordinary or merely conventional, something that may as well be called princely as anything else.

I do not try to draw a picture of Mr. Balfour. His face, I presume, is familiar to Americans through the photographs which now daily adorn the Press. But I have never seen a photograph of him which fully renders the benignity of his expression. Still less can any photograph reproduce for us the luminous beauty of his eyes. In repose the beauty of them is almost feminine. When he is on his feet in the House this softness or sweetness disappears; the eyes flash and burn ; the fire in them is deep, and in anger or in a high mood their gentleness turns to strength, sometimes to passion. The voice is melodious when not strained, and has varied modulations. What we in America humorously call the English accent is not to be expected from a Scot, yet neither has he the method of speech that prevails beyond the Border. If the features are not commanding, the whole figure of the man is instinct with dignity, and on a platform he dominates when he does not care to coax. Not much gesture. In caricatures you mostly see him with his hands on the lapels of his coat; which is hardly a gesture, nor does he seem to have studied the art of delivery as it is understood on the stage.

What does all that matter? $\mathrm{He}$ is an orator. Perhaps he and Lord Rosebery are the last of the 
orators, and both are debaters of resource. If we put Lord Rosebery first as orator, Mr. Balfour is unmatched in debate. He learnt in the best school, indeed the only school in England, the House of Commons, which Lord Rosebery, to his lasting regret, never had an opportunity to enter. A parallel between these two might be drawn to cover many other points of likeness and of unlikeness, but there is no room, and no Plutarch to do it. Of Mr. Balfour by himself there is still much to say, and this, at any rate, must be said, that whatever the imperfections of his leadership or the untimeliness of his resignation, no man ever doubted the singleness or sincerity of his devotion to public duty. It has carried him far from the flower-strewn fields in which he would have liked best to wander, and there is in his whole career an unselfish sacrifice of his tastes and preferences to the demands not of Parliament only, but of Empire. 


\section{CHAPTER V}

SIR WILLIAM HARCOURT-DOMESTIC AND POLITICAL RECOLLECTIONS

$M^{\text {R. LEWIS HARCOURT'S long-delayed pro- }}$ motion in Cabinet and political rank has come at a critical moment.* But the first thing it recalls is the memory of his father, Sir William Harcourt. One cannot but think how Sir William would have rejoiced in his son's success. Never, I should think, had there been a more beautiful relation of father and son than between these two. The affection of each for the other was deep; their devotion without stint or limit. They were much more together than is usual. The son was sent to Eton, but never to a university. Upon his return from Eton he gave up his life to his father; became his private secretary; lived with him and for him. The father, in turn, taught the boy politics, statesmanship, and the world. There could have been no more competent master. Said the father :

"I can never repay Lulu for what he has done. He has done everything. He has sacrificed everything; at any rate, he has postponed his entrance into public life till much later than he ought; and adjourned his chances for distinction. All this and much more he has done that he might be of use to me."

This was said at Malwood in I899. I had been

* December, 1910. 
asked to Malwood for a short visit. The day before I was to have gone came a telegram putting me off till the next week. When I arrived Sir William said :

"You have heard of Lulu's engagement, and you can guess why we asked you to come later."

And after some other explanation came the sentences above quoted. They show you the other side of a man who has been thought in public a little austere, peremptory, and masterful. The true Harcourt was kind-hearted and affectionate; generous in character, with a strong nature capable of being strongly moved.

Five years before this he had been Chancellor of the Exchequer in Mr. Gladstone's fourth and last Ministry, and had brought in the Death Duties Budget which had revolutionized English finance and some other things. Mr. Lloyd George's Budget of last year is but the logical and inevitable sequel of Sir William Harcourt's in I894. The day after this exploit I met Sir William at lunch. He called to me from the other end of the table:

"What do you think of my Budget?"

"I think I had rather not tell you."

" Nonsense. Can't you say whether you think it good or bad ?"

"Well, if you will have it, I think it a brigand's Budget."

I suppose I ought not to have said it, but I thought then, as I think now, that it was the dividing line between the Old and the New. He had broken with the traditions of the Treasury. He was taxing Capital instead of Income. His new finance was political, and something worse than political. He had adopted the doctrine of ransom which $\mathrm{Mr}$. Chamberlain had first proclaimed and then renounced-that property must 
pay a ransom in return for the protection of the State. He levied a fine upon the transmission of wealth from father to son. He appealed to class jealousies and hatreds. He invited the poor to transfer to the shoulders of the rich a great burden of taxation. $\mathrm{He}$ asked the working classes to understand that they in future were to pay less than their share, and the rich -whom Mr. Lloyd George now calls the idle richto pay more than their share. At the bottom of it all lay a motive of politics. He wanted the votes of labour, skilled and unskilled, and believed they were to be had in this way. And that is why I called it a brigand's Budget.

The phrase seemed a little abrupt and there was a slight pause. Then Sir William said :

"So that is what you think. Well, you may like to know that both Sir Isaac Holden and Lord Rothschild have been to see me this morning, and both approve of my Budget."

As these were two of the richest men in England, the retort told. What Sir Isaac Holden thought I never knew, but I saw Lord Rothschild next day, and, having Sir William's permission, told him what had been said. He answered :

"Oh, no. Harcourt misunderstood me. I told him there was one provision of his Budget, touching the method of valuing and taxing certain properties after death, which I approved. But I never said I approved the Death Duties, for I do not."

Some years after that I was in Wiltshire, and this question of Death Duties came up. Indeed, it is always coming up. It never rests. It was said long ago that revolutions never go backward. It happened that three great properties lying close to each other in Wiltshire had lately passed by death: Longleat, 
belonging to the Marquis of Bath; Wilton, the Earl of Pembroke's, and Longford, owned by the Earl of Radnor. Lord Radnor had twenty-five thousand acres, Lord Bath fifty-six thousand, and Lord Pembroke sixty thousand. They are all Conservatives. I asked one of them what the effect of the Death Duties had been. He gave a very deliberate answer :

"The effect has been to cripple the estate and its present owner. I have had to dismiss a large number of gardeners, gamekeepers, labourers, and others employed in one way or another on the estate. I have had to cut down my subscriptions to charities. I have had to reduce the amount of my tradesmen's bills. I have retrenched in every possible way to make two ends meet, and they don't meet. If I hadn't property elsewhere I could not keep this house open.

"If you will ask the men whom you meet as you walk about, gardeners, hedgers, ditchers, all kinds of agricultural hands, carpenters, blacksmiths, no matter who, you will soon find what they think of the Death Duties. They have all found out that though I pay the duties in the first instance the cost and burden of them fall in a measure on all those who are in any way dependent on me. If you will put the same questions on the other two estates about which you know, you will be told the same thing."

In other words, Sir William Harcourt's expectation that the Death Duties would bring in a political profit to the party which levied them has been, in these three capital instances, disappointed. The political result is startling. Wiltshire, formerly divided, sent to the present House of Commons an unbroken delegation of Unionists and Conservatives; or perhaps broken by one.

It is the more remarkable because the Conservatives 
never took up the challenge Sir William threw down. Mr. Balfour, then leader of the Opposition, speaking the same night, guarded himself against the supposition that he opposed Death Duties in principle. On him as well as on his Liberal opponents lay the party obligation to appeal, in one way or another, to the majority of the electorate. He has never proposed to repeal them. It would not have been necessary to repeal them, for the Budget is a yearly measure, and when the Conservatives came into power, in 1895 , they had only to refrain from re-enacting these duties and they were dead. But the Death Duties formed part of every Conservative Budget while the Conservatives were in power, as well as of every Liberal Budget while the Liberals were in power. They have come to stay. Neither party dares drop them. It is a rule or tradition that a duty once imposed remains; or remains so long as there is need of the moncy it produces. The lesson of Wiltshire is lost upon Liberals and Conservatives alike.

There were days-I mean from I894 onwardwhen the Liberal Party was torn with the dissensions between Sir William and Lord Rosebery. I am not going into that unhappy dispute except so far as to say that Sir William thought himself entitled by length of service and ability to be Prime Minister. So he was, but not by the following he had attached to himself. If the Qucen had asked Sir William in I 894 to be Prime Minister there is no reason to suppose he could have formed a Government. Yet he was so powerful in the House of Commons, which he led, that it rested with him to give Lord Rosebery an efficient support; or to withhold it. Lord Rosebery's friends thought this efficient support inefficient ; thought it grudgingly given; and there grew up 
between the two men an estrangement of which the consequences were injurious and even disastrous to the party. It was visible in private as well as in public. Years after, in I 899, I was at Dalmeny, and the day I left one of the younger members of the household asked me :

"Where are you going from here?"

"To Malwood."

With the grave ironical humour characteristic of the speaker came the answer :

"I call it indecent."

But Malwood was a very pleasant place to go to. Not a great property. Sir William had bought ten or twelve acres in the New Forest and had built himself a good and interesting house, and there was content to live. It was much later that he came unexpectedly, by the death of the direct heir, into Nuneham, a fine estate near Oxford. At Malwood everything but the trees and the soil and the heavens above was new. He was not often suspected of sentiment by those who knew him as a Parliamentary gladiator; matching himself from time to time against Disraeli and against Gladstone, and coming out of these encounters, whether victorious or beaten, with honour. He was ever a fighter. But he had a warm heart for his friends, and there was a Garden of Friends near the house, in which each plant or shrub had been given by a friend, and served as a memento, an inscription on each. A pleasant notion, with perhaps an Elizabethan air, and pleasantly carried out.

There were giants in those days, and Sir William Harcourt was one of them. A giant in stature and physical bulk, the head powerful, and carried high, perhaps haughtily; the features carved with an 
heroic touch. He was a force; not in Parliament only, but in the world, in the service of the law, and even in journalism. I believe his real ambition was to be Lord High Chancellor. If there was any question of his knowledge of the law, that would not have stood in his way. He certainly knew as much law as Lord Brougham, of whom Lord Lyndhurst said that if he only knew a little law he would know a little of everything. Sir William was, in truth, a jurist ; and to be a jurist is more than to be a lawyer. He had a mind saturated with the principles of jurisprudence.

He had been at the Parliamentary Bar and gave up an income of $f_{\mathrm{I}} \mathrm{2}, 000$ a year to go into politics. On the Woolsack he might, at a pinch, have done as Disraeli sometimes did when he came late and unprepared into a debate which he had to close-pick up the facts from the speeches. But Sir William would soon have mastered anything to which he gave his mind; as he did finance when he became Chancellor of the Exchequer. There was no more adroit debater ; none more dangerous. And, on the whole, there was no figure in the public life of his time, Disraeli and Gladstone excepted, which more attracted the eyes of men than his. They said, or perhaps he said, that Plantagenet blood ran in his veins. I know not, but there was in him beyond dispute the kingly spirit of that great line of Kings. 


\section{CHAPTER VI}

LORD ROSEBERY - A PERSONAL VIEW OF AN ENGLISH STATESMAN

$\mathrm{N}$ what I have written before now concerning Lord Rosebery I have written with reserve; nor can I now depart from that reserve. But I suppose I may say, in explanation of what I write and do not write, that my obligations to him are of longer standing and are greater than to any other Englishman. I owed to him my acquaintance with Mr. Gladstone and the many days spent in the great Minister's company in London, at the Durdans, at Mentmore, at Dalmeny House, and elsewhere. I owe to him many other relations with other men and a great deal else of what has been most delightful in all the years I have spent in England. These kindnesses cover a period of more than thirty years. When at the Durdans some months ago I looked in the visitors' book for the date of my first visit. It was in $\mathrm{I} 880$ and that was not the beginning.

I forget whether I have ever said how I first came to know Lord Rosebery. It does not much matter whether I have told the story or not, for if I have forgotten, whom it most concerns, nobody else will remember. It is, at any rate, an illustration of the easy way in which such things are done here, and would not be so easily or often done in New York.

It was Mr. Frank Lawley to whom I owe my introduction to Lord Rosebery. Mr. Lawley had been 
Mr. Gladstone's private secretary, had been much on the Turf, of which he had a great knowledge, had a good position by birth, and was a leader writer on The Daily Telegraph. His acquaintance was a large one and I imagine he had had Turf relations of some sort with Lord Rosebery, about whom there was ever a group of men who found means to be serviceable to him. Frank Lawley, in any case, was a man of the world, and knew the ways of this English world, which, it is ever to be borne in mind, take a great deal of knowing. He had a real kindness of nature and was always ready to do a good turn to any one whom he liked. We had only a casual acquaintance and hardly an interest or idea in common, but he was none the less ready to put his gifts of good nature at my disposal. As we were talking one day, Lord Rosebery's name was mentioned and Lawley said :

"Of course you know Rosebery?"

"No."

"But you don't take the pains about such matters you should. Rosebery is becoming every day a greater figure, and, in your position as journalist, more important to you. You ought to know him. I will see what I can arrange."

The next day came a note from Lawley:

"I am commissioned by Lord Rosebery to say that he hopes, if you have nothing better to do, you will dine with him to-morrow night at 8.30 . Mind you do."

That was all-not a word from Lord Rosebery himself, except this message through Lawley. What Lawley had told him I never knew. Lord Rosebery lived at that time-it was in 1878-at No. Io7 Piccadilly, the house which had formerly belonged to Baron Meyer de Rothschild, and had descended 


\section{ANGLO-AMERICAN MEMORIES}

to his daughter Hannah, whom Lord Rosebery had married in that year. It was afterwards sold to the Savile Club, and by that unusual club is still occupied. A house very like many others in that part of London, with an outlook across Piccadilly upon Green Park; an enchanting piece of landscape in the heart of the West End of London. Baron Meyer seems to have found the house ample for his tastes. It was not till he built Mentmore, in I85I, that his aptitude for great splendour became evident, and for a great estate in the country, in the loveliest part of Buckinghamshire.

Mr. Lawley was to have been at this dinner, but had been called away, and of the three persons present there was not one I had ever seen before. Lord Rosebery's greeting was that of a host ; cordial and open and unceremonious, ceremony being a thing which the English prefer to reserve for great occasions. A host and his guest cannot be strangers, and a dinner of four can hardly be ceremonious; or would be very stiff if it were. But a small dinner, where the talk necessarily includes everybody, is either a great success or a great failure. It was not the latter. Lord Rosebery's conversational gifts are, on the whole, unrivalled. They were not then, perhaps, quite what they became later, but they were of a kind rare in all countries and in England unique. His talk had, as he himself had, both charm and authority, which is not a usual combination. His range was very wide, his tact unfailing, his touch electric, with the result, naturally, that you sometimes got a slight shock, just perceptible amid the sparkle, which also is electric. I am suggesting, no doubt, the impressions of many later conversations as well as of this first.

For I have seen Lord Rosebery on many critical 
occasions, public and private. The way in which a man takes victory or defeat is in this country thought a good test of character, and perhaps the ordeal is as severe on the Turf as anywhere in this country. Well, I have seen him win and lose races, and no man could tell from his face whether he was winning or losing. I have seen him on the platform with somewhere from five to fifteen thousand people cheering themselves into apoplexies, and again in the streets of Edinburgh, his carriage surrounded by a howling mob of admirers. These are the occasions on which he looks bored. He can, when he chooses, discharge his face of all expression, and has sufficient control over his muscles, and even over the eyes, to leave the whole visage a blank. But he does not always choose.

In the critical year of his Premiership he was perhaps tried higher than ever before. He was a Liberal and his most dangerous enemy was the Liberal leader of the House of Commons. His best friends were in positions where they could give him little help in the business of managing the party. He had to endure secret hostility in matters of policy and to promote policies which he did not think the best. $\mathrm{He}$ used to say that as Prime Minister he had nothing to do. That is always true in a departmental sense when the Prime Minister is only First Lord of the Treasury, or, as Lord Rosebery was, Lord President of the Council. In his case it was true because he was not master in his own party, nor even in his own Cabinet. It was, in fact, not his own, but an inherited Cabinet. Disappointed ambitions confronted him and undermined his position. The public misunderstood him.

I should think no Englishman in a great position had been more often or more generally misunderstood. $\mathrm{He}$ is a Scotchman-that may be one reason, but the 
chief reason is that his mind has something of the subtle flexibility of the Italian, which to the English is a puzzle. Most of the great Italians have been diplomatists and Lord Rosebery's mind is essentially the mind of the diplomatist. Those to whose wishes he will not bend say he is infirm of purpose. That he is not. Witness the grave crises in which he used the British fleet as Palmerston would have used it. Sometimes, it is true, he went on refining like Burke, or like Goldsmith's Burke, not while the House thought of dining, but while the country thought only of giving a plain answer to a plain question, if he would but put it plainly. He liked to weigh evidence instead of yielding to an overmastering impulse, which is in politics so often the wisest thing to do. He has a respect for logic which the English people do not share with him. Great movements of public opinion or emotion sometimes pass him by.

A recent illustration is as good as any other. In the suspended conflict between Lords and Commons he came out one morning in $T$ he $T$ imes with an appeal to Conservatives to drop Tariff Reform and fight the coming election on the Constitutional question only. He made no allowance for the fact that after years of struggle the Tariff Reformers had captured the Conservative organisation, imposed their will on the Conservative Party, and left the Conservative Free Traders a beaten and helpless minority. What he asked, therefore, was that the triumphant majority should surrender to this helpless minority. Was it in human nature to do that? His appeal passed unregarded.

Lord Rosebery's enemies-I mean political enemies -call him an Opportunist, as Gambetta's enemies called Gambetta, who forthwith accepted and adopted 
the name, defined it for himself, and welcomed it as a eulogy. But the true criticism on Lord Rosebery is that he is not an Opportunist. The ideal policy or the logical conclusion presents itself to him as inevitable. It is an intellectual idol, or perhaps image, and he worships the image which is, like that of most idolaters, of his own creation. Then he cannot compromise. He goes to the stake for it. He renounces power sooner than betray his own belief, and he and his party fall together. It is a very noble trait, but it is not exactly politics.

What would have happened if the Queen had asked Mr. Gladstone, on his retirement in 1894 , to say whom he recommended as his successor, and if Mr. Gladstone had named, as Lord Morley says he would have named, Lord Spencer, and if Lord Spencer had accepted ? It might well enough have altered the course of English politics. It certainly would have improved Lord Rosebery's position. That Lord Rosebery did not then wish to be Prime Minister is well known. It is known that he twice refused the office, and in the end accepted it only upon the Queen's urgency. It might be said that the Queen made a personal matter of it. The Radicals may say what they will, but the influence and even the authority of the Queen were in those last years of her life very great.

If Mr. Gladstone had been asked what he thought about it, and how often, in matters in which he as Prime Minister was concerned, the Queen's ascendancy had been successfully asserted, his answer would have covered a great deal of ground. And if Mr. Gladstone, with all the accumulated authority of his unrivalled experience, and all his force of character, and all his popularity, could not always stand up against the 
Queen, how could it be expected that a much younger man could refuse to obcy her? The Queen had, in fact, taken a strong step when she neglected to ask Mr. Gladstone's advice as to his successor. Her Majesty was within her right in not asking, but was outside the accepted custom and usage. All the more, having taken upon herself the responsibility which she might have divided with her great Minister, was she bound to carry out her scheme, and, if I may say so, force upon Lord Rosebery the office he had the best of reasons for wishing to decline. And she did.

I take it one chief reason for the Queen's peremptory choice of Lord Rosebery was her opinion of his capacity as Foreign Minister. He had been Secretary of State for Foreign Affairs under Mr. Gladstone in I886, and again under Mr. Gladstone from 1892 to I894, and held that post when Mr. Gladstone resigned office. "Under Mr. Gladstone," but under him in name only. For it is known that Lord Rosebery, certainly in I 892 and perhaps also in I 886 , had taken office upon condition that he was to have a free hand. Mr. Gladstone's conceptions and methods of foreign policy were not Lord Rosebery's. They were not those which had made England, from Cromwell's time with brief intervals down to the present day, a great Continental Power. They were not Chatham's. They were not Pitt's. They were not Palmerston's. They had, in fact, brought the prestige and authority of England upon the Continent lower than they had stood since Charles II. For conceptions and methods which had had that result Lord Rosebery did not propose to make himself responsible. He was perfectly loyal to Mr. Gladstone, but he made it clear to his great chief that he believed-which his chief did not 
-in the continuity of English foreign policy, and that he did not intend to depart from the lines Lord Salisbury had laid down.

Mr. Gladstone held views upon Cabinet-making which were not easily reconciled with these claims of independence. On one memorable occasion he had said to an eminent but much younger man whom he desired as a colleague, but in a post to which the eminent much younger man preferred another, that he must be master in his own Cabinet.

But Mr. Gladstone in 1892 had hardly a choice. By the voice of the Liberal Party and by public opinion Lord Rosebery was designated Foreign Minister, and there was no real competitor. Sir Edward Grey had not then reached his present position. He was, moreover, Lord Rosebery's friend and supporter. The retirement of Lord Salisbury was a momentous occasion. Since the death of Prince Bismarck Lord Salisbury had stood alone. There remained no European statesman or diplomatist whose reputation and authority abroad were comparable to Lord Salisbury's. Among English Ministers Lord Rosebery stood next to Lord Salisbury, and to pass him over or to put him in leading strings, or to let it be known that though he held the seals Mr. Gladstone was to mould and direct the foreign policy of Great Britain, would have been to notify all Europe that Great Britain had again, as under Lord Granville, become a negligible quantity in the affairs of the Continent.

I do not suggest that as an argument which would have force, or did have any force, with Mr. Gladstone. In foreign policy, as in all other policies, he believed in himself. To the last, he thought himself right in denouncing the Bulgarian massacres, in opposing the Congress of Berlin, in preaching an Armenian crusade, 


\section{ANGLO-AMERICAN MEMORIES}

in desiring to withdraw from Egypt, in surrendering after Majuba Hill the territory claimed by Krüger, in opposing the purchase of the Suez Canal shares, and so on. He took domestic views of foreign policy, and continued to take them to the last. And it was because he took domestic views that he reluctantly consented to leave to Lord Rosebery, as Foreign Minister, the conduct of foreign affairs. He found he could not have Lord Rosebery on any other terms, and in 1892 a Cabinet without Lord Rosebery as Foreign Minister would have been, for purely domestic reasons, unthinkable. There was one view of foreign policy which Mr. Gladstone well knew Lord Rosebery would never take; the emotional view; and there was one view which Mr. Gladstone himself, whether he knew it or not, had never failed to take: the emotional view. Anything like a compromise between two minds thus constituted was obviously impossible. The one or the other had to give way, and it was Mr. Gladstone who gave way.

It is among the little ironies of political life that a man who had fought such a fight as this and won it, and who made the fruits of victory his own and his country's, should be supposed to be wanting in resolution. During his tenure of the Foreign Office, from 1892 to I894, the voice of England was heard with respect on the Continent ; the policy of England was recognized as a consistent policy; firm, courageous, unwavering.

"On the whole," said Lord Salisbury, " among all qualities essential to a diplomatist patience is most likely to be of permanent use."

He said it in the summer of 1896 , apropos of the Venezuela business, then drawing to its close. $\mathrm{He}$ himself had shown all through the negotiations, be- 
ginning in July, I895, and ending in the autumn of I 896, both patience and firmness.

Lord Rosebery's diplomatic equipment is, in truth, very like that of Lord Salisbury. He, too, has patience; and he has the firmness needful to get the true value out of patience. He has another gift in which Lord Salisbury was pre-eminent-the power of work. I was with Lord Rosebery one night at Mentmore. He sat in his room upstairs, inside a rampart of Foreign Office dispatch boxes, three sides of a quadrilateral and as high as his writing-table. As I left, about one o'clock in the morning, I asked :

"When are you going through those ?"

"Now."

"But that may mean half the rest of the night."

"I can't tell how long they may take till I have looked at them, but, long or short, they must be done to-night. The only way to deal with F. O. business is to start with a clean slate every morning."

I remembered having heard from a Foreign Office clerk that Lord Granville used to leave his boxes unopened for three weeks at a time. And I remembered having met Lord Granville on a Sunday morning in the country, when he learned from a Sunday newspaper arriving about eleven o'clock a piece of diplomatic intelligence of high importance which must have been known in the Foreign Office in London the day bcfore. Well, yes, and I remembered having been told in Berlin that high officials of that highly and deservedly praised German bureaucracy thought themselves lucky if they got papers back from the Emperor three weeks after they had been sent.

"Penal servitude for fourteen hours a day," was Lord Rosebery's own description of his work at the Foreign Office. 'The working-man who thinks eight 
hours a day too much might be asked what he thought of fourteen as a measure for one of the leisured class. But Lord Rosebery, whose name figures often and high on the Turf and in Court ceremonies, and as host and guest in London and in the country and abroad, has nevertheless always been a worker. $\mathrm{He}$ is, for all practical purposes, the greatest living English master of that political and diplomatic history without which a politician or a diplomatist can be only an amateur. If he had not that, and much else, including a knowledge of the world and of men, sometimes cynical but always kindly, he would not be what the great Queen called him, "a heaven-born Foreign Minister." 


\section{CHAPTER VII}

\section{FIELD-MARSHAL VISCOUNT WOLSELEY}

TO what is said about Lord Haldane, Minister of War, I might add some remarks on the present state of the British army, were that not travelling too far afield. It may answer the purpose if I give you a memory or two of General Wolseley -I mean Field-Marshal Viscount Wolseley, but I knew him and all the world knew him so long as General that this title still comes most readily to one's lips or pen. I don't enter upon military controversies, but since Lord Haldane is hailed-by one set of politico-military critics-as the regenerator of the British army, I will quote what a great authority said to me :

"The British army has of late been a good deal pulled about, and has had several doctors all honestly trying to improve its constitution. Lord Cardwell, Lord Lansdowne, Mr. Arnold Forster, Mr. Brodrick (now Lord Midleton), and finally Lord Haldane, tried their hands, each in his own way. Their failures differed in kind and in degree, but they were all failures-or, if Lord Haldane's scheme is not yet a failure, you will see that, with all its ingenuity and scope, it will not stand the test of time."

Then he went on:

"The one man to whom the army owes almost all the efficiency it now has is Wolscley. It was 
Wolseley who introduced short service, and short service is the foundation of military usefulness. $\mathrm{He}$ did it in the face of tremendous opposition, with the Duke of Cambridge, then Commander-inChief, at the head of the opposition. But nobody now denies that it was a reform without which the army would have decayed."

Side by side with that I print another quotation; this one from Field-Marshal Wolseley himself. But first I ask you to remember that this great soldier had served all over the world, beginning with the Burmese War, in I 852-53; then in the Crimea, where he was pretty well shot to pieces, and won his captaincy at twenty; then in India, at Lucknow; then China; then the Red River Expedition in Canada; then the Gold Coast, in command during the Ashantee Campaign; then Egypt, in I882, crushing the Arabi Rebellion; then, two years later, at the head of the Gordon Relief Expedition, which would have ended in success instead of defeat had his advice been taken before it started; then Commander of the Forces in Ireland, and so on. During all this time he rose steadily in rank and in renown. He was thanked by Parliament three times, was raised to the peerage, and later made a viscount. Promotion followed promotion; he was Quartermaster-General of the Forces as early as I880, then Adjutant-General and chief executive officer of the army, I882-85; and again $1885-90$; finally Field-Marshal in 1894 ; and Commander-in-Chief of the army, I895-1900. That is a mere skeleton of his career, but it will serve as the preface I want for my quotation. When the Boer War broke out, the command was not offered to Wolseley, nor was it till Lord Roberts entered the field that the record of British defeats, cheered by 


\section{FIELD-MARSHAL VISCOUNT WOLSELEY 8 I}

the Irish Nationalists in Parliament, came to an end. I met Lord Wolseley during one of those gloomy periods, and to my "How are you ?" he answered :

"Thanks. I am very well, and I spend my time trying to forget that I have ever been a soldier.",

Did you ever hear a more pathetic speech ? He was then but sixty-five. He knew himself still capable of command. He knew why he had been passed over. He had to look on while the War Office at home and the generals in the field vied with each other in colossal blunders, and while, as Lord Rosebery said, the fortunes of the whole British Empire hung in the balance. He knew South Africa. He had powers of organizing and powers of fighting which had never failed him. But the War Office, which had pigeon-holed General Sir William Butler's reports warning his chiefs of what was coming; which sent Sir Redvers Buller to the front, on whom "disaster followed fast and followed faster"; which starved the services and thought forty thousand men could do the work for which a quarter of a million proved to be none too many; - the War Office, of which first Lord Lansdowne, I898-I900, and then Mr. St. John Brodrick, I900-3, were the responsible Ministers, had no use for such a soldier-a tried, victorious soldier-as Wolseley. Their mistake cost England dear; and it cost her best captain what remained to him of happiness in life. He was put on the shelf, and left there.

It is now many years since I have seen Lord Wolseley. The pleasant house in Hill Street, Berkeley Square, is pleasant for other reasons, if it be pleasant. $\mathrm{He}$ and Lady Wolseley are among the privileged inhabitants of Hampton Court Palace. I hear he has aged; perhaps has never recovered from the shock and 
disappointment and the many sorrows, public and personal, of the Boer War. The years-there are seventy-eight of them-have dealt gently with him, but there is nobody on whom they do not leave a mark; they and wounds and privation and fatigue and great responsibilities greatly borne. But down to a recent period the vigour of his mind had not been impaired.

I write with a photograph before me which Lord Wolseley gave me in I895, signed and dated. The signature, "Wolseley," is strong and firm; each letter clear-cut almost as if with a sword; and it is certainly the slash of a sabre which finishes off the " 5." 'The great soldier is in a Ficld-Marshal's uniform. He wears the ribbon and Grand Cross of the Bath, the Grand Cross of St. Michael and St. George, the Star of St. Patrick, nine military medals, each a souvenir of great services in the field; and more clasps than I can count. The signature and date are scored across the ribbon.

None of these decorations would you notice till you had looked at the face, which is rather more than three-quarters front. The strength of it is well rendered in the photograph, and its one weaknessa retreating chin-is altogether hidden. I don't know whether this riddle was ever presented to the physiognomists to read, nor how it happened that a man whose whole life is a record of unshaken purpose and invincible courage should have had the lower part of his face so moulded as to denote irresolution. But there it is. All the rest is as fine as you could wish, every feature chiselled; the forehead broad and full; the poise of the head such as comes from long leadership of men. What the photograph cannot give is the light in the eyes; or in one of them, since the 
other-and it's not easy to tell which-is artificial. But the one the bullets left him is filled with blue fire; which grows deeper as he talks.

Clear as are my remembrances of Lord Wolseley, I despair of making clear to others the vividness of his talk, still more any clear notion of the man himself. But I will quote a sentence or two from an old letter :

"It is because he has something to say on so many matters, and this perfect fearlessness in saying it, that his conversation is successful. There is an alert energy in his manner which seems fitting to a warrior on the war-path ; his store of anecdote and reminiscence is vast, his convictions are free from any taint of uncertainty, and he agrees with Lord Beaconsfield in regarding invective as an ornament of debate."

But his invective was, after all, good-natured. I never heard from him a vindictive word. $\mathrm{He}$ was no more vindictive than a judge on the bench sentencing a criminal is vindictive; though the criminal may think he is. But Wolselcy was never the man to suppress an opinion because it might not be the opinion of others. He was outspoken in all companies, and quite willing that others should be equally outspoken. There is a courage of the drawing-room as of the battlefield, and that also Lord Wolseley had. With it went a cheerfulness which was equally part of his nature : and was the cause of cheerfulness in others. His presence and his talk were alike inspiriting. In that slight shattered body dwelt an invincible force; a happy temperament and a power of endurance no trial had ever shaken, nor any stress of circumstance impaired. I once asked him what was the worst climate he had ever known. He thought, and answered : 


\section{ANGLO-AMERICAN MEMORIES}

"The only place I can recollect where I ever woke in the morning not feeling perfectly fit was Suakim."

It was part of the heroism of his nature to accept things as they came: bullets, fever, and the rest. He was a soldier, and they were in the day's work. He was a born leader of men, and men follow a man who will lead them to their death and his; and him only do they follow. Into the rush of battle and of life, in age and youth alike, pectoris fervor misit furentem.

Writing twenty years ago, when some people were alive who are now dead, I said that Lord Wolseley had been known to send a letter from the Nile to a schoolgirl, in which the burden of just responsibility for the delay in resolving on the Gordon Relief Expedition was laid squarely on the shoulders where it belonged. Now I will add that the girl herself showed me the letter. I said also that Lord Wolseley had been known to repeat the same accusation on his return home in a dozen different companies, and to all comers, and with every circumstance of publicity, as if he intended it to reach the ears of him whom he thought guilty, as no doubt it did.

Yes, but this publicity was never of print. London journalism was then, perhaps, more reticent, more discreet, than it is to-day-at any rate, Lord Wolseley's accusation never, so far as I know, found its way into the papers. I myself was discreet because the guilty person was then alive. But I have no need to inquire of others, for I heard Lord Wolseley more than once denounce the author of that dilatory policy which in its result, though of course not in its intention, left Gordon to be hacked in pieces by Mahdist spears in betrayed Khartoum. It was Mr. Gladstone, then Prime Minister and ever a 


\section{FIELD-MARSHAL VISCOUNT WOLSELEY 85}

lukewarm friend of Gordon, if not his enemy, who held back the relief force during that summer of I 885, while the Nile was steadily falling and an overwhelming savage force was besieging Khartoum.

"I tell you," said Lord Wolseley, "I put every military argument before Mr. Gladstone. I pressed upon him the urgent necessity of haste. I assured him that though others had been discussed, there was but one road to Khartoum, and that was the Nile ; and that as the Nile fell the problem of transporting troops and munitions and provisions by that stream grew each day more difficult. I besought him to act. He would not."

At another time the baffled General put his case still more compactly. Mr. Gladstone, he said, knew well that time was of the essence of the whole matter.

"I was on my knees to Mr. Gladstone for months, entreating him to let us go. He steadfastly refused."

And so Gordon's doom was sealed in Downing Street. Lord Morley, in his Life of Gladstone, makes a half-hearted attempt to put the blame, or some of the blame, on Lord Hartington, then Minister of War. He quotes a sentence from a letter of Mr. Gladstone to Lord Granville, in I888, saying: "I don't think he [Hartington] ever came to any sharp issue (like mine about Zobeir); rather that in the main he got what he wanted." But that is the plea of the accused in his own behalf. The answer is simple. Mr. Gladstone was Prime Minister and Lord Hartington was not. Mr. Gladstone may have had difficulties with his Cabinet as he did about Gordon's request for Zobeir. But he was the most masterful of First Ministers when he chose to be. The truth is, Mr. Gladstone's heart was never in Egypt, and his 
sympathies with Gordon were ever sluggish. No decision was taken till August 8, I 885. Later, Lord Wolseley was appointed to command the expedition. On September 9 he reached Cairo; on October 5, Wady Halfa. Not till then did the Nile Campaign begin. Lord Wolseley's letter to Lord Hartington, recommending immediate and active preparations for an exclusively British expedition to Khartoum, had been written and sent April 8. To that list of facts and dates I do not care to add any comment.

On other great issues he spoke with the same freedom; on Home Rule, for one. His conception of his duty as a soldier did not lead him to silence when he saw danger to his country. In a letter to the Duke of Cambridge, written when $\mathrm{Mr}$. Gladstone was using his great powers for the break-up of the United Kingdom, Lord Wolseley said :

"Home Rule will be the end of the English army."

The sentence is characteristic; a deep meaning, clear to him, expressed in a phrase likely to puzzle those who had not looked at Home Rule with a military eye. His belief was that English soldiers would refuse to fire on Ulstermen whose crime was loyalty to England. But, whatever their reason, an army that mutinies is no longer an army. It is a subject which an Irish soldier who has been Commander of the Forces in Ireland may be supposed to know something about. 


\section{CHAPTER VIII}

MR. WINSTON CHURCHILL-THE BOY AND

THE MAN

\section{I}

MOST people speak of him, or used to, as Winston; perhaps because he was, and still is, being now in his thirty-eighth year, a youthful prodigy. This ease of allusion may denote affection, or may not. It was not from affection that the English called Bonaparte "Boney." There were mixed motives which underlay the re-christening of the ex-President of the United States "Teddy," to which European nations never accustomed themselves. Mr. Roosevelt, with his sure instinct for popularity and what tends to promote it, seems to have encouraged this familiarity. Mr. Gladstone was spoken of, but never to, as "Mr. G." Nor was "Dizzy" used to denote his great adversary except in the third person. In the case of the First Lord of the Admiralty, long before he attained to that great dignity, it was partly a matter of convenience. There were many Churchills and only one Winston, unless you count the American novelist, whom you need not count since he lives in a different hemisphere.

I knew this extraordinary man as a boy at the age of ten. I was staying with Lord and Lady Randolph at Great Forsters, a fine old Elizabethan mansion near Egham, which they rented for two successive summers. The boy Winston had, even at the age 
of ten, the same clear notion of what he wanted and how to get it which has distinguished him ever since. He wanted, one morning, to go boating on the river. He invited his mother, Lady Randolph, his younger brother Jack, and me to go with him. He took command of the party, first on land and then on the water. Nobody thought of disputing his claim. I had lived enough in boats to see that Winston, though with no great skill in watermanship, knew what he was about, and though he ran some needless risks, it was never necessary to interfere. The critical moments were never dangerous, and we landed as we had embarked, quite safely. I paid him the compliment on his captaining that was his due, to which he kindly answered, "But I see you know as much as I do about rowing."

It was during this same visit that I gave Winston a little present. It is the custom in England, and the boy, with all his premature ambitions, was attractive. For years after I never met him that he did not renew his thanks. That is not the custom with the English, whose genius is for repression and reserve. It was perhaps the American half of him which expressed itself in this way. Nobody, I think, would describe the American genius as one of repression and reserve, nor did Miss Jerome when she married an English husband cease to be an American with more than the usual American exuberance of nature. It was this clinging to her Americanism which was one of the secrets of her popularity in England : and among the best people in England.

Since those pleasant days at Great Forsters, in 1884 and $\mathrm{I} 885$, I have met him in many companies and circumstances, and it is only of what I have scen-or almost only-that I shall have anything 
to say. His career of military and quasi-military service and adventure as soldier and correspondent deserves a book to itself, and, indeed, he has written more books than one, and very good books they are. By the time he was twenty-six he had seen and shared in some ten campaigns, in Cuba, in India, in Egypt, and in South Africa. In all he was distinguished, and he wears I know not how many military medals and clasps. But I am not writing a biography, and I refer to none of these adventures except his escape from a Boer prison, and to that only in order to say that having heard the statements on both sides, including a full one from himself, I think his conduct open to no reproach nor even criticism. Civil or military, his life has been a battle, and most of his battles have been victories.

When he came to America to lecture on the South African War I met him at Government House, in Ottawa. It was during Lord Minto's GovernorGeneralship, and Government House was then, in much more than an official sense, the social centre of the Dominion. Lady Minto carried all before her. Winston's lecture tour had been organized by Major Pond, then at the head of the lecture business in America, a man with good qualities, but prone to take a purely business view of matters which, after all, depended on something besides good business management for success. It was of common knowledge that between him and the lecturer there was friction. Friends were called into council and the strife was appeased, but there was one evening when all Ottawa was crowding into the theatre, all unaware of the doubt whether Mr. Churchill would appear. He thought a point of honour involved, and that had to be disposed of before he would consider anything else. 
In New York the Irish, whom in New York and elsewhere we have always with us, were not disposed to welcome Mr. Churchill as a lecturer, nor perhaps even to allow him to be heard. They gathered in some force in Carnegie Hall, not having Mr. Carnegie's peace precepts in mind, bent on disturbance : bent on silencing the Englishman who presumed to take his country's side and tell his country's story of a war which Mr. Patrick Ford disapproved. They made no demonstration when Mr. Churchill appeared on the platform. They kept quiet till he mentioned the Boers, and at that name they broke into a storm of applause. Mr. Churchill waited till it ended. Then he said :

"Gentlemen, I am glad to hear those cheers. You are quite right to cheer the Boers. They are a brave people, and they deserve all the cheers you can give them."

Then again the cheers broke forth, but this time not for the Boers, but for Mr. Churchill. His tact, his quickness in assuming that it was the courage of the Boers, and not their politics, the Irish applauded, won over the hostile minority, and the minority merged in the majority. 'To the end there was no further outbreak. Now that, I suppose, is the kind of talent which serves a politician better than any other. Mr. Churchill has shown it on a hundred platforms since. In Carnegie Hall it was an inspiration, but even an inspiration may improve by practice, and there is now in England no politician who of late years, and especially during the last two General Elections, has spoken so often and always in every speech with such fullness and freshness and effect as Mr. Winston Churchill. He is supposed to be the most unpopular Member of the Ministry or of the 
Ministerial Party. Probably he is, but he is also the most popular. Politics I eschew, but the man about whom the leader of the Opposition and the Prime Minister contend in the first great debate of a serious Session of Parliament is not an ordinary politician. Mr. Balfour pours ridicule on him for his performances at the Sidney Street fight, where "he was in the zone of fire-he and a photographer, both risking valuable lives." To which Mr. Asquith, who is understood to find now and then a difficulty in reducing his colleague to order, replied :

"My right honourable friend, if he will forgive me for saying so, suffers from the dangerous endowment of an interesting personality."

Precisely, and that is why I write about him and you, I hope, read about him.

With one other remark I will get clear away from this zone of fire and from all proximity to immediate controversies. I must presume that the Conservative censures on him are heard beyond the Atlantic. These censures are frequent and extremely bitter; even more bitter than those upon Mr. Lloyd George. The reason for the extra bitterness is simple. Mr. Lloyd George was from the beginning an unregenerate Radical in whom all the natural and acquired vices of Radicalism were fully developed at an early age. Nothing, therefore, but Radicalism, in its most extreme socialistic form, was ever expected of him. But Mr. Churchill was born into the world a Conservative, and a Conservative he remained till Mr. Balfour, then Prime Minister, rejected his application for Cabinet Office. Then he crossed the floor of the House and has ever since acted with the Liberals, who knew the value of their recruit and gave him what Mr. Balfour had denied. That is what the 
Conservatives tell you, and that is why their dislike of Mr. Churchill is so extreme. It does not stop short of something like social ostracism. Mr. Churchill's social position is not unlike that of Lord Spencer in 1886, when he followed Mr. Gladstone into the Home Rule camp; for Lord Spencer, though he never passed from one party to the other, was then regarded by the Unionists as having betrayed the cause of the Union. None of these things do I affirm or deny. I simply expound the English view on one side and the other.

You will not understand Mr. Winston Churchill unless you understand that the passion or the overmastering impulse and rule of his life is to be doing something. His power of work is prodigious, almost commensurate with his passion for it. Whether he ever rests or ever sleeps I do not know. But I have seen him pretty often in circumstances which for most men would be a holiday, and for him were none. Country-house life in England is supposed to be a life of indolence, or of that energetic amusement by which the Englishman recruits his exhausted energies. Not so with him. Dunrobin, where there is sport of many kinds, may furnish an instance. He was at that time writing that life of Lord Randolph Churchill which, by common consent of the judicious and of the general, is reckoned among the few great biographies in English literature. He toiled at it all the morning and part of the afternoon and, for aught I know, at night also. His experience in journalism had taught him to work at full speed at all times, and in no matter what surroundings. Occasionally he asked me to his bedroom to talk over some subject I knew about. His bedroom had been turned into a literary workshop, strewn with books and papers 
and all the apparatus of the writer. He had brought with him a tin box, some three feet square, divided into closed compartments. This was his travelling companion on journeys of pleasure.

Like his father, he wanted ample room for his materials, and his hostess had provided him with a large writing-table. This was covered with papers, loose and in docketed bundles, but all in exact order for ready reference. Now and then he gave me a chapter to read. He did not want compliments, but criticisms, or perhaps an opinion on a doubtful point. Into this Life he was putting all that was best in himself; and in it shine forth qualities not always conspicuous in his party speeches; judgment, broad views, patient accuracy, and a strict sense of proportion; which, perhaps, are not to be expected in party speeches. If you queried a statement, he always had a fact or a considered opinion to support it. His task was the more delicate because Lord Randolph and Winston had not always agreed on matters which concerned them both; nor did Winston think his father's political course at the most critical moment of his career judicious or even defensible, as every reader of his book may see. But he was on every point the most conscientious of biographers, and, whatever view he may have taken of this or that incident, his Life is a noble tribute to his father. Lord Randolph's fame stands the higher for this book.

When we left Dunrobin we found that Winston had reserved a compartment in the railway train for himself and for his big tin case of papers. $\mathrm{He}$ shut himself up there, and during that long journey read and wrote and worked as if a Highland railway train were the natural and convenient laboratory in which litcrature of a high order was to be distilled. 
It might be said of Mr. Churchill, as the late Lord Russell of Killowen said of Sir George Lewis, that with all his gifts and capacities, the most remarkable thing about him is his courage. It may be seen in private and in public alike, in little things and in great. He may not like the word, but he is a born Nonconformist; a label which, ecclesiastically and socially, a Churchman may well decline to accept as applicable to himself for any purpose. The great body of Mr. Churchill's political supporters, including the whole, or nearly the whole, of his constituents in Dundee, are, if you consider the Church of England only, Nonconformists. I assume that their Member is not. I never heard that when he changed his politics he changed also his religion or his church, which many Englishmen would consider the same thing. But, as I use the word neither ecclesiastically nor socially, nor yet politically, it is in fact descriptive of Mr. Churchill.

$\mathrm{He}$ is by nature and temperament a Dissenter. His critical faculty is at least equal to his constructive faculty. He likes standing alone, apostle of Democracy though he be. He never forgets that his grandfather was seventh Duke of Marlborough, and even when he derides and abuses dukes in general, there is a mental reservation in favour of the princely line of Blenheim. On a platform his manner is one of authority, and his appeal is not to the sympathies but sometimes to the intelligence and very often to the prejudices of his audience. He stands apart, aloof, almost alone; the blue blood flowing to his finger-tips, or, if you like, to the tip of his sharp tongue. He stirs impatience in friends and foes 
alike. Often the most agreeable, he is sometimes the most absorbed, abstracted, distrait of companions, whether with women or men; unwittingly disturbing the sensibilities of the more delicate sex. You may hear a sentence now and then repeated which fell, or is supposed to have fallen, from the lips of one of the most gifted of beautiful beings; a testimony to his charm and a complaint of his carelessness in matters which women think no man entitled to neglect.

More than once his political chief has rebuked him for assuming functions or declaring policies which only the Prime Minister has authority to announce. It was supposed he meant to force $\mathrm{Mr}$. Asquith's hand. I rather imagine he had an irresistible impulse to proclaim the gospel of the moment as it presented itself to his own mind. Foreign Affairs, Finance, the Rights of Labour, the policy of the party-nothing comes amiss to Mr. Churchill. Critics who thought his administration of the Home Office irregular or fitful, or in violation of the fixed traditions of that great department, have gone so far as to suggest that his control over all that complicated business would be more complete if he allowed his colleagues to manage their own affairs. They insist that, of all other things, he should suffer the Prime Minister to be Prime Minister, and that Mr. Asquith, under the friendly guidance of Mr. Redmond, should direct the policy of the Government and the procedure of the House of Commons.

His courage might often be called audacity. Early in life he took for his rule of life the tremendous sentence of Danton. He did not need to have it tattooed on his breast like a sailor, nor embroidered on his under-vest, as the Legionaries of Honour are said to do in France when first this coveted yet too 


\section{ANGLO-AMERICAN MEMORIES}

frequent distinction is given them. It was inwoven with the fabric of his soul. His career sparkles with audacities of many kinds. I have known him challenge a dignitary of the Roman Church to a controversy on ecclesiastical history, of which he knew little and his adversary much. But Winston's expertness in debate worsted and finally silenced the dignitary of the Roman Church.

For other great personages he showed little of that deference to which they were used. An amiable familiarity of address suited him better than starched civilities. "Excellency" or "Sir" in those days seldom passed his lips; an ambassador's surname, or even an abridgment of it with "little" as a prefix, served his purpose, even if it surprised the Ambassador and the company. There is, I suppose, nobody who sets greater store by the consecrated courtesies due to his great office than a diplomatist of high rank; but if any offence was taken it was not shown. In the presence of Royalty itself Mr. Churchill's attitude was not always one of restraint.

At Blenheim Mr. Winston Churchill has always been at home, and always had a suite of rooms known as his, and always reserved for him. His abandonment of the Unionist Party did not, I believe, much affect the friendship between himself and his cousin the Duke of Marlborough, which had always been close. The Duke is still a staunch Conservative, and is likely to hold office in the next Conservative Government, as he did in the last with much credit to himself. He and his cousin were in Paris together on a holiday not long before Mr. Churchill publicly cast in his lot with the Radicals. A friend who met the Duke alone one morning at the Ritz asked, 
"Where is Winston?" With a humorous demand for the immediate damnation of his wayward cousin, he answered, "Upstairs in his room, hard at work." The splendours of Paris had no more power to draw him from his desk than had the splendours of Dunrobin.

For a man who has fought his way to the top so early in life, Mr. Churchill, as you see, has shown little regard for conventions and little desire to conciliate. In New York he met everybody, but he would sit in the midst of the most delightful people, absorbed in his own thoughts. He would not admire the women he was expected to admire. They must have not only beauty and intelligence, but the particular kind of beauty and intelligence which appealed to him ; if otherwise, he knew how to be silent without meaning to be rude. It is, of course, a considerable and a rather unusual social gift to be able to disappoint the reasonable expectations of those about you, yet offend nobody. It was useless to remonstrate with him. He answered: "She is beautiful to you, but not to me." Or sometimes in Mr. Sargent's familiar retort when critics could not discover the likeness of a noble yet unlovely portrait to the lovely original :

"I paint what I see. I cannot see her otherwise."

Mr. Churchill may or may not have the artist's eye but he has his own; and in that, and not in the eyes of others, does he put his trust. It is the same in matters of judgment. It is his own judgment that he follows, and, right or wrong, that is the only judgment that is worth anything to him.

Upon the social boycott (if there be one), of which I wrote the other day, I will make one other remark. Mr. Churchill married two or three years ago the daughter of the late Colonel Sir Henry Hozier and Lady Blanche Hozier, a girl whom London had 
greatly admired in her girlhood, and admired still more in the fuller flowering of her beauty, her gifts of mind, and her charm of character, after her marriage. A society-any society-which thinks it desirable for purely political reasons to deprive itself of such an ornament is the chief loser by its intolerance.

There are times when the Cabinet Minister looks the boy he was on the river issuing orders to his mother and me. But he is, in fact, older than he was then. Of the changes he has undergone one is more noticeable than the rest; or noticeable when you look for differences. The skull has filled out under that inward pressure from a brain which had to find room somewhere. The arch of the forehead has a more Roman shape; more of the half circle and less of the flatter breadth of earlier days. The blue eyes have become the eyes of the thinker, and their depths are such that the light in them seems to come from far away.

Not long ago I sat opposite this new Winston for some two hours at a small round table where one other person completed the company. This third person was an American of renown, with much knowledge of the matter which just then happened to interest us three and the rest of mankind, to use once again a forgotten phrase of General-President Zachary Taylor. 'The matter was Mr. Lloyd George's Budget. Mr. Churchill and the American of renown were both, in a sense, experts on this subject. They had, at any rate, a knowledge of the facts and much practice in the public and private discussion of them.

They discussed those amazing proposals of political finance for two hours. As opponents they were well matched, and neither of them made the least approach toward converting or subverting the other. The sun 
went down, or the electric light went out, on a drawn battle. The methods of the two were as unlike as their opinions. The American came into action with all his forces and sent resounding volleys into the enemy, who nevertheless was not swept off the field. Much familiarity with the art of war had taught Mr. Churchill the art of waiting, and when an opening came his single bullet found its way home.

What interested me most, as I listened and looked on at this combat, was Mr. Winston Churchill's face and demeanour. The conflict did not excite him. He might have been sitting in his library with his six thousand volumes about him, and thinking out a problem of statecraft or a party manœuvre. In the eyes was the glow, not of battle, but of reflection. He thought while his adversary talked, and the processes of thought somehow expressed themselves on the smooth expanse of brow. You may stand sometimes on the upper engine deck of a steamship, and watch through a sheet of plate glass the pulsing of the machinery below. It was so here. If you did not see you felt the working of a great intellectual force.

The scene passed, indeed, as upon a stage. We were dining at the Ritz, and the room was thronged with well-known people. Mr. Balfour sat not far off, a glance of inquiry coming our way at times; possibly wondering whether he might not better have given his former follower the Cabinet office he wanted. With a keener eye for the future and a surer guess at the growth of this young man's capacity for politics, who knows but the Unionist chief might have kept the mutineer in his proper camp? It was evident enough to all these lookers-on that a duel was in progress between Churchill and the American, known 
to many of them as Mr. Bourke Cockran, with a great fame as a talker, in London not less than in New York and in Washington and on Long Island. There was no group in the room which so much attracted men and women alike as this pair of athletes; themselves aware only of each other, and of the struggle over the arid details of finance which they, like Mr. Gladstone, knew how to make fascinating, even to minds which cared not greatly for figures or fiscal puzzles. Since then, night after night and twice or three times a day during the last election, Mr. Churchill has spoken on these dry matters to hardheaded Lancashire audiences and captivated them all. The Home Office was his reward, and in the Home Office, as at the Board of Trade and throughout his adventurous career, he kept the public guessing; and the question was for ever on all lips: "What will he do next ?"

Presently the question answered itself. It was thought advisable that Mr. McKenna should leave the Admiralty, and so Mr. Churchill suddenly became First Lord. Another surprise, or rather two surprises; the second being that the new First Lord, though not known as a friend to an adequate Navy, left his Radical or Little England prejudices behind him at the door of the Admiralty, and within a few weeks had reorganized, if not revolutionized, the naval policy of the Government. He set himself to restore the discipline and efficiency which under $\mathrm{Mr}$. McKenna had been impaired; to restore the tone of the Navy; to create a War Staff; and to put the business of the Navy on a business basis. What he will do on the other vital matter of building battleships and cruisers and destroyers is not known as I write; nor does it depend wholly on him. But, if 
I understand Mr. Churchill, he is not the man to put his hand to a great and patriotic work and withdraw it before the work is done.

Moreover, there is reason to believe that his transference from the Home Office to the Admiralty was less sudden than it seemed. Wise men in Whitehall will tell you that for many months before he became First Lord Mr. Churchill had been often a visitor at the Admiralty, and that he had studied the organization and business of that great office. If he did that, it certainly was not with a view to careless administration when he took charge. His worst enemies do not deny to him ambition, nor doubt that to whatever station in public life he may be called, he means in that station to achieve success. To success sound administration is the only road, and sound administration at the Admiralty means a Navy equal to the work it has to do.

In Mr. George Peel's The Future of England, lately published, a piece of concise thinking picturesquely phrased, occurs a passage which Mr. Churchill's Radical friends may read with profit. Says Mr. Peel :

"In that danger zone where argument dies away and only might flourishes, we have initiated the reorganization of our armaments; remembering that, of all the gods and goddesses, only one never lays aside her spear and shield and helmet. It is the goddess of wisdom."

With that goddess the advocates of a stingy shipbuilding policy have perhaps no very intimate acquaintance. But since they have votes in the House of Commons, it will be Mr. Churchill's first business, when he introduces his naval estimates, to improve the relations between them. 


\section{CHAPTER IX}

SIR EDWARD GREY - A PERSONAL AND DIPLOMATIC IMPRESSION

WICE last year it happened to Sir Edward Grey
to become, in a moment, and for a moment, and in one instance apparently by accident, the most conspicuous figure in the British political world. $\mathrm{He}$ was already, and had long been, a personage of distinction in public life, and also in private. But I cannot remember that, until he made in the House of Commons his speech on Arbitration, he had ever concentrated public attention on himself as one of the few men in the Ministry, or in public life, who are to be reckoned with permanently. The impression he then made was renewed and strengthened by his more recent speech on the Moroccan question. The quiet power with which he then vindicated the position and diplomatic action of Great Britain showed him a stronger man than his best friends had suspected him to be. Before that there had been hints of indecision, of over-caution, of a preference for tentative policies. But now, without a note of passion or an incorrect phrase, he put Germany in her place; where she has since stayed. Mr. Gladstone said of him long ago that he might be anything he chose, but that he chose to go fishing. He still goes fishing, and has written a book on that gentle art, which is an authority, and is still an example of one of the best types among the 
English; the country gentleman. But he is much else than that, Radical Northumberland being his home.

Last summer some of the limelight which was turned so freely on Mr. Roosevelt fell incidentally on Sir Edward Grey, though it is not a thing he cares for. There was something novel and unexpectedly human in the Foreign Secretary's serving as guide to the ex-President through the mazes of the New Forest and introducing the naturalist-hunter of the United States to the birds and flowers of Great Britain. It was an agreeable episode in both those lives. The stalwart Britons-and there were many of themwho could not forgive Mr. Roosevelt for his lecture at the Guildhall and his admonition to them to do for Egypt what Mr. Roosevelt thought right, or get out, took a kinder view of him when he made friends with Nature on the intercession of Sir Edward Grey. And the state of feeling here was for some time such that Mr. Roosevelt's debt to his New Forest friend was considerable.

I first met Sir Edward Grey at Tring Park, Lord Rothschild's delightful place in Buckinghamshire, a house with which many other similar memories connect themselves. The date I cannot give you, but what matters the date? It was the event which mattered; it is always the event; the meeting with some new human being of interest; the new experience; the new view of life at an angle different from any earlier view; the revision of hearsay impressions in the presence of the man himself. But it must have been before I left England in 1895; and between 1892 and 1895 when Sir Edward was UnderSecretary for Foreign Affairs in the ministries of Mr. Gladstone and of Lord Rosebery. Prior to that he 
had held no office. When he entered the Foreign Office Lord Rosebery was Forcign Minister and the new Under-Secretary had the advantage of serving his apprenticeship to diplomacy under Lord Rosebery, the most accomplished of Foreign Ministers in recent times, Lord Salisbury alone excepted; with a reputation abroad second only to Lord Salisbury's, and held upon the Continent to be a lineal diplomatic descendant of Lord Palmerston, who is still, to most good Britons, ultimus Romanorum. Lord Palmerston bequeathed to Lord Rosebery his conception of the British fleet as the chief European instrument of peace. They both used it as such.

So, it is true, did Lord Salisbury, but he is remembered most vividly of all as author of the saying that the British fleet could not climb the mountains of Armenia. It was one of those sentences uttered by Lord Salisbury in his most epigrammatic mood, intended and adapted to cool the hysterical enthusiasms of the sentimental factions which were wont to demand impossibilities both of the Minister and of the fleet. It was a counsel of sense and prudence like so many of those by which Prince Bismarck kept the Prussian generals in order, after Königgrätz and after Sedan. But a Minister who sets himself to stem the tide of popular or military feeling in the moment of victory must expect to be denounced as preferring peace to honour. Denounced he was, and little he cared for the denunciation. But history sometimes sets a black mark against the name of such a Minister, unfairly and untruly; nor even for that need he care. These are days when all historical judgments are subject to revision.

But to go back to Tring. Sir Edward Grey could not then have been much more than thirty. He 
looked even younger till you noted the thoughtfulness of the face, the lines of thought already visible ; sketched if not incised. Tall, straight, erect, with the bearing of a man on whom the stamp of the patrician was plainly set. It was a face which the winds of heaven had visited. There was, and is, something Norman in the features; they are high, clean cut, finely modelled; such as Duke William of Normandy and his knights might have brought with them to England and bequeathed.

There are men of whom you say when first seen that they are both thinkers and men of action. You would have said that of Sir Edward Grey, and you would have been wrong. Man of action he has never been, in the sense which made Palmerston and Bismarck men of action before and above all. It may not be quite fair to try anybody by those high standards, but how otherwise are you to take a man's measure? Young as Sir Edward Grey then was, and holding only a subordinate post in the Foreign Office, you nevertheless felt that he was in his right place. The first business of a diplomatist is not to make war but to avoid war. To keep the peace is the test of his capacity. He was obviously a man who brooded over the problems presented to him. Deep on his front engraven, deliberation sat. The group of people in the smoking-room were talking, as is the habit of groups in smoking-rooms. Sir Edward stood on the hearth-rug listening, reflecting, weighing opinions and characters. Now and then his eye wandered to Mr. Waldo Story's marble bas-reliefs of Greek goddesses which line the four walls. A winged Victory looked down from the prow of the marble ship above the chimney-piece. But I take it not victory nor the means to victory, but the means 


\section{I06 ANGLO-AMERICAN MEMORIES}

whereby alike victory and defeat might be escaped, were what filled his mind.

None of all this would he have told you. He was a man who had ever the rare power of keeping his thoughts to himself; as if they matured better in his own brain than by contact with the thoughts of others. It seemed then, and it has seemed ever since, that he had something of the Sphinx in him :

Who'll tell me my secret

The ages have kept?

Sympathetic as he was, he stood aloof. He has stood so ever since.

With her husband was Lady Grey ; since dead ; and the memory of her is a pathetic memory. A stately figure in black velvet; beautiful, attaching; like her husband sympathetic, and like him remote yet surrounded by admiration. That was the atmosphere in which she lived. It was a true nobility of nature to which this homage was paid. Upon him her influence, if you may believe those who knew them best, was constant and always for good. It was Sir Edward's way to take detached views. Lady Grey came close to the things of real life; understood them, and understood that no man ever gains his full stature in seclusion. Hers was the kind of power worth a hundred times the power a capable woman can wield by help of a piece of printed paper called a ballot. Character, not the vote, is what tells.

Lady Grey, if I understood her at all, had a wise patience, rare in either man or woman. She was content to use such means as came to her hand. In herself, and through him in their closeness of intellectual companionship, she had an authority which suffragists will never get from the suffrage; nor from any other source. The loss of an influence so benefi- 
cent as hers is an irreparable loss. Nor did the part she elected to play diminish her womanly charm, but enhanced it. Never was it defiled by the dust of the arena; never debased by the tumult of the marketplace.

It was as a friend of Lord Rosebery that Sir Edward Grey finally accepted the post of Foreign Minister in Sir Henry Campbell-Bannerman's administration of 1905. He has been Foreign Minister ever since. He was, in the first instance, one of Lord Rosebery's "Ambassadors" to a Power, a Ministry which to Lord Rosebery had become foreign. The others were Mr. Asquith-how strange that name in that connection now seems!-Lord Haldane, and Sir Henry Fowler, afterwards Lord Wolverhampton, deceased only last year. Sir Edward then passed as a Moderate; a strong, dry, useful man. What else than a Moderate could a friend and pupil of Lord Rosebery be? Sir Henry Campbell-Bannerman was not a Moderate; then nor ever; it was not in him to be ; and Sir Edward Grey's first refusal of the Foreign Office as colleague to that shrewd Scot was understood to be on account of his Radicalism. It was believed to be upon the late King's intervention that he accepted.

I know not, but what we all know now is that the effect of Sir Edward Grey's opinion on domestic affairs has ceased to be a moderating effect. He has become, since 1906, a Radical of the Radicals. His public speeches on the Budget, on the Parliament Bill, on Home Rule, and on Woman Suffrage, are those of a man prepared to go all lengths. The conservatism which once was his in English politics he now kecps for affairs abroad; where no man with knowledge and judgment can be anything but Con- 
servative. Yet even in Foreign Affairs Sir Edward became at one critical moment an extremist. It was he who announced to Europe when Austria annexed Bosnia and Herzegovina that annexation required the assent of the signatory Powers to the Treaty of Berlin, and that the act which Austria had done of her own motion could not be held valid till ratified by a Conference of these Powers. Alas! he had to look on while European Powers gave their separate assent, each for reasons sufficient to each, and till the assent of England no longer mattered. Count Aerenthal, and not Sir Edward Grey, was the victor in that encounter.

Sir Henry Lucy, with his usual felicity of characterization, once labelled Sir Edward "The Veiled Prophet of the Treasury Bench." It was a picturesque and accurate description if limited to the days before he made his Radical speeches. Now the veil has been torn off and the prophecies are like other prophecies: useful in debate because nobody can contradict them.

A Minister who has stood by the side of Mr. Lloyd George in the Albert Hall, and spoken as Sir Edward Grey spoke for the Woman's Revolution, has renounced once and for all his Conservatism of other days. He renounces, on that gravest of all issues, his allegiance to the Prime Minister. He ranges himself with the forces of disorder and destruction. $\mathrm{He}$ is the ally of a man who is for a new policy of Thorough : more menacing, as well-wishers of England think, than Strafford's; menacing not only to the liberties but to the existence of this ancient Commonwealth. Whatever exists, exists to be abolished, and anything is good enough to rebuild with, provided it has never been tried. The dragging of women into politics is a cause for which American precedents are invoked. 
Well, it is true enough that five or six American States have adopted Woman Suffrage; California the most recent of them. But they are all States on the Pacific coast or the Pacific slope; in all of which government, so far as the States themselves are concerned, is in an experimental and fluid state. They have embarked on other political adventures in the same spirit of easy confidence. So loose is the organic structure of those societies that one or another part of the fabric may be disturbed without much impairing the cohesive energy of the whole. It is idle to argue from communities still in the cradle to a country like England of which the institutions are the deliberate growth of centuries. But for an exposition of the fallacies underlying the citation of these American excursions into uncharted seas I need only refer to Mrs. Humphry Ward's impregnable letters to $T$ he $T$ imes.

It is pleasanter to pass from that and to come back to Anglo-American matters. In those, if no more in domestic matters, he is Conservative. His two Arbitration speeches and the settled purpose of which they were the expression, endear him to Americans. It may be true that Sir Edward chose that moment in which to make a party move. Mr. Asquith, who would otherwise have spoken in that debate instead of his Foreign Minister, was in Switzerland, by his daughter's bedside. A conflict was expected on the naval estimates, not only between the Government and the Opposition, but between the two wings of the Ministerial forces, of which one is known as the Little Navy wing. It was an awkward crisis. How is a Minister to face his enemies in front when half the army behind him is on the point of mutiny-has, in fact, already mutinied ?

With a fine gift of strategy Sir Edward turned the 


\section{10}

attention of the House and of the public away from the question of Dreadnoughts to Arbitration : Arbitration as a sudden, substantial, practical issue of international politics. Months had passed since the President had announced his desire for an agreement "with some great nation" for an Arbitral Court to adjudicate on every question which cannot be settled by negotiation, including even territory and national honour. It is not clear that England is prepared to entrust her territory and national honour to the Hague Tribunal or any other tribunal. It is quite clear that the United States will not submit the Monroe doctrine to arbitration. So perhaps we may consider that part of President Taft's proposal as not much more than a pious aspiration, or an "unwearied pursuit of unattainable perfection." Enough is left for the practical policy of Arbitration. Mr. Taft is no fanatic; no visionary; but a sober-minded magistrate who knows that States are governed in their relations with other States by a policy of enlightened self-interest; and cannot be governed otherwise. One of the interests of Great Britain and the United States is, to his mind, a good and clear understanding of what they have in common. His appeal was an overture of friendship. The Foreign Minister of England grasped that outstretched Presidential hand. Then Mr. Balfour grasped it. Then all England cried out to these two leaders, "Well done!" and then America said "Amen!" Sir Edward Grey, in the absence of the Prime Minister who might or might not have seized this occasion, had pledged Government and the governed alike to the President's policy.

Seldom has any Minister achieved so great a triumph by a single speech. But what I ask you to notice is 
that to no Minister would the confidence of the country have been given in whom the country had not confidence already. Here again it is character which counts. Here again it is the governing class which speaks through Sir Edward Grey. His pledge is personal as well as governmental. $\mathrm{He}$ and the President are of the same mould; two men who understand each other and come together on a great Anglo-American issue, perhaps the greatest of all, because they are built alike and because the soul of each is a soul of truth and honour. 


\section{CHAPTER $\mathrm{X}$}

VISCOUNT HALDANE, WAR MINISTER, METAPHYSICIAN, LAWYER, AND SOCIALISTIC RADICAL

"I WHO know Kant by heart."

It is Lord Haldane who is speaking, and the speech is a characteristic one, or characteristic of one side of him. Somebody had undertaken to expound to him the mysteries of German metaphysics, and this was his answer-the beginning of his answer, at the end of which the expounder departed unhappy. Whether he does in truth know the whole of the Critique of Pure Reason by heart or not, he has at any rate an acquaintance with German philosophy more full and minute and exact and comprehensive than most Englishmen. Whether it fits him or unfits him for his duties as War Minister may be a question. Of the fact there is no question. Not one of his colleagues is in this respect his rival. Not one of his opponents on the Front Bench has a similar turn of mind, except the author of the Defence of Pbilosopbic Doubt. But neither in Mr. Balfour's case nor in Lord Haldane's is it thought that the meditations of the closet add much to their efficiency as debaters or political leaders.

Indeed, a question might be asked more broadly still; the question whether on the whole and with all due recognition of Germany's position in the world of thought, it really is good for the English mind to be Germanized. If there be an authority entitled to respect in such matters it is Huxley's, whose range 
was far wider than that of the mere specialist. Huxley was asked whether Science did in fact owe as much to Germany as the Germans tell you. He answered : "In the accumulation of facts, yes. In the use made of them, no. They are at the head of the world in methods of investigation and in the completeness of it. But in those constructive processes on which everything most valuable in science depends, the French are their superiors and the English are their superiors. It is by these two peoples, the French and the English, that the fabric of science has been built up."

It is Schopenhauer and not Kant with whom Lord Haldane is most closely identified. He translated and published many years ago Schopenhauer's World as Wiil and Idea, a kind of Handbook to Schopenhauer. $\mathrm{He}$ made the great apostle of despair the delight of English maidens and young matrons. I have met many a one who talked Schopenhauer fluently, and sometimes one or more who had mastered him and knew what his system really meant and what his influence on life and thought had been. I once said so to Lord Haldane, who answered : "You have a wide acquaintance."

That is No. 1. The Lord Haldane whom the British public knows is better indicated by ancedote No. 2, as follows :

When the new Minister of War introduced in the House of Commons his Bill for the reorganization of the British army he made a speech five hours long; a specch crowded with facts, with figures, with complicated expositions of the new scheme as a whole and in detail; the whole consecutive and luminous. In answer to a question he said :

"Yes, I made it without a note. I had nothing in 
writing, not even a page of figures. But that is nothing. In the days when I was busy at the Bar I have sometimes gone into court not knowing which one of half a dozen causes would come on that day, but quite ready to go on with any one of them, and not a note in any one of the six."

They were causes of importance and difficulty, for his practice lay in the Court of Appeals, the Privy Council, and the House of Lords. The considered decisions of these courts are sometimes published in The Times, and fill six or eight columns, closely printed in small type. I imagine that not many barristers concerned in cases of that magnitude dealt with them in the same way. But Lord Haldane was one of the most distinguished and most successful among them all.

He entered the Campbell-Bannerman Cabinet an Ambassador from Lord Rosebery, as did Mr. Asquith himself and Sir Edward Grey. They remained as hostages. They are to-day neither Ambassadors nor hostages but component parts of the Radical force which is dominant alike in Cabinet and party. They took the stump for Mr. Lloyd George's Budget. They joined in the campaign against the House of Lords, the sole check in this country upon revolutionary legislation. They acquiesced in Mr. Asquith's surrender to Mr. Redmond and his declaration for Home Rule. I offer no criticism on any of these performances. I only chronicle them, and I only do that because they explain, and nothing else can explain, the change in Haldane's political position.

With his soft manner and smooth voice and philosophical turn of mind, he may not impress you as a man designed by Providence to destroy an army and then to create and govern another. But there have 
been such men before now, and it is not a matter on which a civilian's opinion is of prime importance. The soldiers say-or some of them say-he has handled the technical part of the business in a very competent way. Perhaps it is too soon to be quite sure. The German staff are reported to be pleased with his scheme, but their pleasure is an equivocal eulogy. The German Emperor invited him to be present at the great manœuvres of last autumn and paid the English War Minister compliments, the precise value of which seems, for the same reason, doubtful. We are assured that the Committee of Imperial Defence, with its world-wide authority, is satisfied that the Minister has done what is possible. But Lord Esher, himself a permanent member of the great Army Council, has lately said that, to put the Territorials into working order, sixty thousand recruits must come in yearly, and that no such number can be had.

There is, however, one English soldier, not a member of that committee, but excluded from it, whose opinion would probably go further with the English public than all others. I mean Lord Kitchener. But Lord Kitchener does not take the public into his confidence.

I met Lord Haldane at a party in London some two years ago. You do not expect much serious discussion in a throng of that kind, but he made a remark which led me to say I should like to ask him one question.

"What is it?"

"I should like to know how it is that an army is to be made better by abolishing some of the best battalions in it."

Just then a lady came toward us to whom he wished to speak, and my question was left unanswered. "We 
will discuss it some other time," said Lord Haldane. But that other time has not yet arrived. I asked the question because I had a friend or two in the battalions marked for destruction. The 3 rd Battalion of the Scots Guards was one. It was admittedly one of the finest in the service. A little later I dined at the mess of the officers on guard duty at St. James's Palace. It was a dinner of eight, including two civilians-the other a man well known about the Court and formerly private secretary to Lord Salisbury. From beginning to end not one of the officers said a word about their impending fate. Where else could this reserve have been kept? What made their silence the more remarkable was the fact that they all knew, though my civilian friend and I did not know, that the battalion had received orders to report at Buckingham Palace next morning, there to be mustered out by the late King. It was, in fact, mustered out on that Saturday morning. The late King undertook this duty as the highest compliment he could pay the battalion. When they surrendered their colours he received them, saying they should be safely kept till they could again be delivered into the care of a battalion which had carried them always with distinction. Every soldier was grateful to the King for those words. His praise was understood to mean that he hoped and expected the battalion would presently be called into being once more. Whether Lord Haldane was grateful I do not know. The criticism was obvious. The King was Commander-in-Chief of the army, and he clearly meant to signify his disapproval of the dissolution of the battalion.

In private life Lord Haldane used to be known not only for agreeable and brilliant qualities, but for an independence of opinion and life rare in this country. 
The opinion of the multitude was not his. Even in such matters as dress he showed himself careless of custom. Whether this mutinous spirit had anything to do with his project of army reconstruction must be left for others to say.

I thought Lord Haldane entitled to be called a Socialist Radical even before he declared for woman suffrage. If it were questioned before it cannot be questioned now. To this point has philosophy led Lord Haldane as it has led Mr. Balfour; or, if it has not led them, it has not hindered them. There is not in English history or in any other history any revolutionary movement so revolutionary as this. Lord Haldane, Mr. Balfour, Sir Edward Grey, and other men who on many great questions are moderate and sane, deal with this in a light-hearted way which it were no slander to call flippant. The foundations of society are to be broken up, experimentally. The balance of political power is to be transferred from one class to another. It has been done before where only classes were concerned; done with agony and the sweat of blood and political convulsions. Now, when it is made an issue between the sexes, and the family which is the unit of English life is to cease to exist, the matter is handled with levity. The Prime Minister believes and says it will be disastrous, but flings the reins on the neck of his Cabinet to drive where they will. Lord Haldane may consider no issue of practical politics comparable in importance to the subtleties of metaphysics. Perhaps none is, but if that be so surely the metaphysician might stick to his metaphysics, and leave revolutions to be made or prevented by those who think revolutions a serious business. It is not the first in which he has been engaged. The Constitution lies in ruins about him: he assenting to the 


\section{8 ANGLO-AMERICAN MEMORIES}

ruin and going himself to the House of Lords to make sure that the ruin should be complete, and the Parliament Bill, so called because it destroys the Parliament, be enacted into law. That also, we are to suppose, is a child of the philosophical detachment of mind which is able to regard merely mundane things as secondary, and only les choses de l'esprit as vital to national life. Smooth phrases and play of mind and skill in dialectic are not, however, the gifts by which great English Ministers have become great. 


\section{CHAPTER XI}

FOUR SPEAKERS OF THE HOUSE OF COMMONS

I

MR. HENRY BRAND, MR. ARTHUR PEEL, MR. GULLY

I HAVE known four Speakers, beginning with $\mathrm{Mr}$

Henry Brand, who held this great office from I 872 to 1884 , who was afterwards Sir Henry Brand, G.c.B., then Viscount Hampden. He belonged to a family of whom one was John Hampden; a name which, notwithstanding its connection with the Dacre peerage, I suppose even Mr. Lloyd George would recognize as illustrious. In the days when Mr. Brand was Speaker I used to go now and then to the House of Commons. The figure of this amiable gentleman was a prepossessing one. All Speakers, I may say, in their robes and wig and seated in the great chair, like a Chair of State, have an air of that dignity which is inseparable from this office.

Mr. Brand had it. He was not, I think, by nature, a man of high authority. The habit of command or of quick decision was not natural to him. Such as was his he won by practice. The office educated him into a competence for its duties. There was never any doubt that he knew the rules of the House and how and when to apply them. And finally there came a moment, a memorable moment about nine o'clock one February morning of $\mathrm{I} 880$, when he rose to the height 
of a great occasion and reasserted once for all not only his own authority as Speaker, but the prestige and power of the House over its own rebellious members.

The veiled form of rebellion then called Obstruction had been brought by the Irish Nationalists to a pitch of perfection never before known. The pioneer in this business of preventing business by an unscrupulous use of the rules framed in order to carry on business, was Mr. Biggar. The moral twist in Mr. Biggar's nature had its outward counterpart in a curious physical malformation and in a face which seemed intended as an example of Darwin's theory of the Origin of Species. He entered the House unknown but not unobserved. Mr. Disraeli observed him, put his glass into his eye, surveyed this new species for a moment and turned to a colleague by his side with the question :

"What is it ?"

Mr. Parnell was not above adopting Mr. Biggar's tactics. He was like Mr. John Russell Young when managing editor of $\mathcal{T}$ be Tribune. I asked Young one day where he got an idea he announced and desired me to carry out.

"It doesn't matter where I got it. I would take an idea from Benjamin if he had one."

Benjamin was the office boy. Mr. Parnell, with Mr. Biggar and other eminent Irish Nationalists and office boys to help him, deliberately set himself to paralyse the legislative efficiency of the House and to bring the House into contempt. It was a policy in which he gloried. A friend-if he had a friend-once asked :

"Mr. Parnell, how did you acquire your extraordinary knowledge of the rules of the House?" 
"By breaking them," answered the Irish leader.

He broke them all, one after the other, but his real strength lay not in breaking them, but in using them. On this occasion obstruction had gone on for three days. The Speaker intervened, the House sustained the Speaker, but the ingenuity and pertinacity of Mr. Parnell and his colleagues were, during thesc three days, more than a match for both Speaker and House. It was said afterward that Mr. Brand might have acted sooner than he did. Down to that time he had been thought rather easy-going. Probably he was no more easy-going than other Speakers whose lot had fallen on easier times. Nor does it matter. When he struck, he struck home. He rose in his chair on that February morning and announced to a hushed House that in his judgment the sense of the House was that the question be now put. And he put it.

I did not see this great act. I wish I had. But nine o'clock in the morning is not an hour when one is likely to find oneself inside the Palace of Westminster, nor was there any reason to suppose that anything was going to happen. I was told afterward that Mr. Brand had taken few members into his confidence. It was a secret too tremendous to be trusted to many, even of the party leaders; all of whom, the Irish excepted, were with him. He had, however, consulted with the chief officials of the House. Unlike most officials, they, or some of them, were capable of taking an unofficial view. The Irish, of course, denounced it as tyranny, a violation of their privileges, a coup d'état; and I know not what else. But the Speaker's view was a very simple one. He said later to his friends:

"It cannot be that the rules of the House were intended to make a small minority of the House rulers 
over the majority. The will of the majority is meant to prevail. That is the object of the rules. That was the evident sense and desire of the House as a whole. It only remained to find some means of giving effect both to the purpose and intent of the rules and to the evident resolve of the majority. Only the Speaker could do that. I thought I ought to take that responsibility and I took it; and there never was any question that I rightly interpreted and executed the will of the House. I wish no other defence than that."

But it has gone further than that. The power which the Speaker then usurped-if he usurped it-was soon after conferred upon him by the Standing Orders which govern the procedure of the House, and those orders are still in force.

To an American familiar with the practice of the House of Representatives in Washington all this may seem no great matter. But the Speaker of the House of Commons is never a "Czar," nor ever a "Joe" Cannon, nor ever in any sense a party man or the agent of a party's will. He does not appoint committees. There is no Committee on Rules, as in the House of Representatives, for the purpose of controlling legislation and of controlling it in the interest of a party. It would not have been possible for $\mathrm{Mr}$. Brand to bring obstruction to an end if he had had only one party behind him. It was only because he had the House behind him that he could do it. Moreover, he went beyond all precedents and traditions in order to do it; and in this country precedents and traditions have-they still have, but nobody knows for how long-the force of law, and sometimes more than the force of law.

Of the three other Speakers about whom I wish to 
say something I will take Mr. Arthur Peel, now Viscount Peel, first. He succeeded Sir Henry Brand, and there is a curious story about the way in which he came to succeed him. He was the son of the great Sir Robert Peel, the idol and ideal of Mr. Gladstone's political life. He had been twenty years in the House, yet had won no particular distinction in debate or otherwise. He seldom, if ever, spoke. But Mr. Gladstone-for the choice of a candidate for Speaker rests in the first instance with the Prime Minister of the day-said to his colleagues that he should like to make the proposal to Mr. Peel if only as a compliment to his father. He was told that Mr. Peel would not accept.

"Never mind. I wish he should have the chance to accept."

So the proposal was made and, to the surprise of Mr. Peel's friends, was accepted. The House is not obliged to choose the candidate presented to it by the Prime Minister, but Mr. Gladstone's authority was still very great in 1884 , and his nominee was elected unanimously. Mr. Peel had then to address the House. He spoke with an eloquence nobody expected ; with dignity, and in that House of Commons tone which is supposed to be attainable only by long practice. The House was delighted, and from the day he took the chair, in 1884 , down to 1895 , when he retired, he ruled wisely and well.

I often saw Mr. Peel. All Speakers, for the reason I gave above, are impressive. It is not too much to say of this one that his air was majestic. "Like a King upon his throne," I once heard an experienced observer say, but in truth the number of kings who upon good testimony are kingly in their demeanour is not unlimited, and the number to whom you would 
apply the word majestic is more limited still. The most striking scene I can remember was that in which a tumult arose in Committee : insults were flung across the floor of the House, the two sides roared at each other, blows were exchanged, the Chairman was powerless, and the Speaker was sent for. As he was seen emerging from the space behind the Chair the House grew still; the passions which had rent the air subsided; order reigned before a word had fallen from those grave lips. The mere presence of the Speaker sufficed. It was a triumph of personality far more than of official position.

A tall, erect, strong-featured and strong-natured man. The first Sir Robert Peel was a cotton spinner, from whom came the great fortune which the great Sir Robert used greatly, now, by descent to a last eldest son, pretty much squandered. The Speaker was the youngest son of the Prime Minister. The doctrine of heredity is no longer a favourite doctrine with the men who have possession of the platform. It seems useless, therefore, to ask whether the present Lord Peel owes any debt to either of his ancestors, or to which. He is quite capable of standing alone.

$\mathrm{He}$ is a great orator. It was not merely the one speech on his election to the Speakership which proved it. A frequent orator he is not, but whenever he has spoken it has been in the grand manner. He belongs to the school of which Mr. Gladstone was the most illustrious example; not the greatest school, but one of the greatest. When Mr. Disraeli described Mr. Gladstone as intoxicated with the exuberance of his own verbosity there was too much truth in that unfriendly sentence. But Lord Peel, who has the sonorous eloquence of $\mathrm{Mr}$. Gladstone, has never had the fluent facility of speech and the unrestrained 
copiousness of diction which so often brought that orator to disaster. If I were asked to choose among all the speeches I have heard one which had every great quality of oratory in the least compass, I should choose Lord Peel's speech at the dinner of farewell to M. Waddington, on his retirement from the French Embassy to London which he had long honourably filled. He said everything that needed to be said, said it with finish, with distinction, with rhetorical power, with a vibratory emotion which held a brilliant company breathless, and his speech was just six minutes long.

The present Speaker's predecessor was one of the politest of men, yet firm enough to rule the House. He was Mr. Gully, the third of the Speakers I am writing about; a barrister and Liberal politician; able in both capacities but not supremely able in either. It was a surprise to the House when Mr. Gladstone chose him as a candidate for the Speakership. The surprise was not quite the same as in $\mathrm{Mr}$. Peel's case; or not for the same reason. Perhaps the occult motives of Mr. Gladstone were never made public. Mr. Gladstone had many occult motives; many which he did not care to expose to the light of day. In this particular case they do not matter much. Mr. Gully's genial personality may have been one of them.

My acquaintance with him began at that highly miscellaneous Anglo-German watering-place, Homburg von der Höhe. It was a place where a man was more likely to be seen in his shirt sleeves-moral shirt sleeves-than anywhere else. Mr. Gully had few reserves. His appearance and manner were alike prepossessing. He had the diplomatic art of talking frecly and revealing nothing. He was popular and 


\section{I26 ANGLO-AMERICAN MEMORIES}

he had a popular wife. 'The Speaker's Chair he put far behind him ; there was no room for it in the little German town under the lee of Frankfort. The Prince of Wales-the late King-who liked him, had set everybody an example in such matters, and $\mathrm{Mr}$. Gully saw no reason why he should not follow it; nor was there one.

The circumstances in which he had come to the Speakership might tend to promote modesty. There had been a contest, which was unusual. Mr. Gully had been elected by a narrow majority-and a party majority at that; which was more unusual still. The Conservatives had publicly announced that if, after the election known to be imminent, they came back with a majority they would turn Mr. Gully out; or rather, since the Speaker's tenure of office expires with the Parliament in which he has been elected, they would not re-elect him. But he proved to be an efficient Speaker, with a wide knowledge of Parliamentary law and a mastery of the rules and traditions of the House of Commons; with quickness, which is indispensable, and tact, which is desirable, and force. When the dissolution came they nevertheless attacked him in his constituency and tried to defeat him and to prevent his re-election to the House, which would, of course, have prevented his re-election as Speaker. That effort failed, and when the Conservatives came back with a majority, their hostility to Mr. Gully died away, and Mr. Balfour, then as now leader of the Conservatives, proposed Mr. Gully as Speaker and the House elected him unanimously. He reigned ten years, I 895 to I905, and was a good officer, and left behind him a good name when, in 1905, he took a better and became Viscount Selby. The most inveterate republican may admit 
that it is better when he is told that Mr. Gully chose his wife's name as that by which he was to be ennobled. A rare, if not unique, instance.

\section{II}

MR. JAMES LOWTHER

Mr. Lowther, the present Speaker, in any account you may take of living celebrities stands very near the front. Not only because he is Speaker, but because he is $\mathrm{Mr}$. Lowther. To give him his full title, he is the Right Hon. James William Lowther, P.c. - magic initials which stand for Privy Councillorand Member of Parliament for the Penrith division of Cumberland since I886. A Conservative in his private capacity; of no politics whatever in his capacity of Speaker; no, nor was he in his capacity of Chairman of Committee of Ways and Means and Deputy Speaker; a post second in importance only to the Speakership itself. This he held from 1895 to 1905 , when he was chosen Speaker. He had, therefore, ten years' training in the business of presiding over the House of Commons. And it was because he came brilliantly well out of this long trial that he was made Speaker. Had he been a poor or even a moderately good Chairman of Ways and Means he would never have been put into this higher place.

You might, nevertheless, describe him as a country gentleman; born for sport and the care of an estate ; one of the "idle rich" whom Ministers of the Crown to-day denounce as so many cumberers of the ground; an "idle" man, in this case, with a habit of working ten, twelve, fourteen hours a day. Look at that well- 


\section{I28 ANGLO-AMERICAN MEMORIES}

set-up, athletic figure, with the head on it of a man of the world and a student; and the eyes of a man who can hold a gun straight; brown-haired, blue-eyed, brown-skinned and bearded; a man every inch of him.

Beyond doubt he comes easily within the range of Mr. Lloyd George's Limehouse invective. He does not work with his hands; he is not in receipt of an old age pension; he owns a property in Cumberland ; his associates are also of the idle rich. Worse than that, he is the eldest son of the Hon. William Lowther, who is uncle to the present Earl of Lonsdale, the actual head of the Lowther family; to whom the Speaker is first cousin. A family of many and far-reaching distinctions; none perhaps superior to that of the Speaker, since the Speaker is First Commoner of England, a title of true pride. Here also is heredity, in which Lord Rosebery, speaking lately at Manchester, declared himself a believer: "though I do not care about hereditary legislators"; meaning, no doubt, that he did not care about an hereditary legislature, having succeeded after many years in inducing the House of Lords to abolish, so far as a vote of that body could abolish, the hereditary principle as a principle of legislative right.

The Speaker's father was long a diplomatist, then an M.P.; then in 1892 retired to private life. $\mathrm{He}$ is at this momemt of writing eighty-nine years old; and still young. A mind of genuine force; convictions which he never tampered with; a firmness of nature as of a rock, and, over all, that saving grace of humour which stands between its happy possessor and tragic views of life. Now, as half a century ago, it lights up his face; his eyes glow with it, and the softening, cheering, inspiriting influence of it descends gently upon those about him, and the radiance of it 
fills the room. It is so with the son. Of all qualities it is the most human and the most rare.

No American visitor can have gone westward through Kensington without seeing Lowther Lodge; one of the few private residences in London which stands in its own and ample grounds; commonly called a Queen Anne house ; of red brick, with gables and steepled chimneys; a picturesque piece of architecture which would look at home in a country landscape, and in London seems a little exotic. A delightful house inside; full of treasures; renowned for its hospitality. Until lately there presided over both Lowther Lodge and Campsea Ash, the Lowthers' place in Suffolk, a mistress who had rare qualities of mind and character; a hostess of both tact and authority; an accomplished, original, most amiable and kindly woman, who is dead.

Of such descent and of such a parentage the Speaker of to-day comes rightfully by the gifts which have won him the respect, the liking, the affection of the House. He is unlike all past and probably unlike all future Speakers. In knowledge none ever excelled him; in his way of applying his knowledge to the matter in hand he is absolutely unique. When Gambetta was President of the French Chamber of Deputies you saw the use a man of genius could make of his genius in a place which did not seem to call for genius. I draw no comparison between Gambetta and Mr. Lowther, and I don't know that genius is the word which would be thought descriptive of Mr. Lowther. All I mean is that each of the two men brought to bear upon duties largely of a routine kind qualities far removed from the region of routine.

'That sense of humour which, as I said, Mr. Lowther possesses is perhaps of not less use to him as Speaker 


\section{I30 ANGLO-AMERICAN MEMORIES}

than those other traits which might seem more germane to the office. There are various ways of keeping 670 gentlemen-well, a majority are gentlemen-in order besides the strict enforcement of the Standing Orders. The power of taking detached views-a power inseparable from humour-is one. Mr. Lowther has not said a harsh thing since he has been Speaker, but he has made many an honourable member, including the Prime Minister and other Ministers, look a little foolish. He does it by setting the honourable member's conduct or statement in a new light. It is done in a sentence; in the fewest possible words; never arguing, never doubting ; inflexible but smiling ; and members have grown shy about calling down on themselves these flashing thunderbolts. The terse sentence with which he sends an offender back to his seat is like a sentence to the Clock Tower, except that the offender whom the Speaker has once dealt with seldom offends again. $\mathrm{He}$ is master of the unexpected; and the most convinced extremist or enthusiast, as well as the most accomplished cynic, suddenly becomes aware that there is another way of seeing things than his. His manner is parental but peremptory; and appeal from his decision there is none; or none at the moment, and therefore practically none at all.

But it is easier to form a notion of Mr. Lowther from a little acquaintance in private life than from the Speaker's Chair; easier to form and much more difficult to express. But I will venture to take an instance. I was visiting at Campsea Ash three years ago when Mr. Lowther came down, after a late adjournment of the House. There was a crisis. There have been many crises of late years, and I will not say which. The Speaker had had to interpose. The 
whole situation was delicate and difficult. At dinner, for which he arrived with the coffee, nothing was said. Later in the evening there was a reference to the incident of the day, and one of us asked how it had ended. That question was easily answered, and I think nobody would have put another. But having answered it, the Speaker went on. He gave us such an account of what had happened as nobody else could have given, because nobody else had seen it from the Chair. He did not hesitate to lay the blame where it belonged. He told us what his rulings had been, and why. He summed up the case as a judge on the bench might sum it up; a strong judge, strong enough to impose his view or his will on the jury while leaving them, to all appearance, free and independent. The Speaker has, I am always saying, as Speaker, no politics. In private and before his constituents of Cumberland Mr. Lowther is still a Conservative. I will not say whether he was Conservative or Liberal during this exposition; but he was, for the purposes of his statement, one or the other. He had formed a strong opinion and expressed it strongly. No bitterness, of course. Anything like bitterness or rancour is alien to his nature, as it is to the nature of most strong men. But when he had ended his account he had carried us all with him. We were like the jury who said it was no credit to a certain great barrister to win so many causes, because he was always on the right side.

During so much of the session as the weather permits Mrs. Lowther receives her friends on the Terrace of the Houses of Parliament and gives them tea. There is usually a large company of guests; women in the majority, not unnaturally. If the state of business in the House permits, the Speaker appears for half an 


\section{I32 ANGLO-AMERICAN MEMORIES}

hour or less. He is in full dress, minus wig and robes. With them he has laid aside his authority of manner. $\mathrm{He}$ is simple; most Englishmen are; and the simplicity is apt to increase as the rank or position increases. In the House he is vigilant, determined, unrelaxing; it does not answer to be otherwise. Here on the Terrace all that is gone. $\mathrm{He}$ is simply entertaining his wife's guests. If you care to see whether he succeeds in this praiseworthy effort you have only to look into the faces of the women to whom he is talking. Mrs. Lowther as hostess has the kindliness which underlies all social successes; the graciousness which a hostess of high place must have; the social knowledge and diplomacy incidental to, and also indispensable in, the discharge of her duties. Both have the art of putting people at their ease.

The state and splendour of the Speakership are kept up, no matter who is Speaker. The Speaker's house is part of the Houses of Parliament. You drive through Palace Yard and through an archway facing the entrance, and the Speaker's House is at the opposite end of the court. It was designed as a house of hospitality. When you have climbed the staircase to the first floor you may pass from room to room, each opening into the other and all looking upon the river, till you come to the great dining-room hung with official portraits, with seats for some sixty guests at table. Crowded as these rooms often are with much that is most brilliant in the social life of London, they are themselves brilliant. When the Speaker gives his Parliamentary dinners everybody comes in uniform or in court dress. At Mrs. Lowther's evening parties there is often the same blaze of colour, not always to the advantage of the more delicate 
beauty of the gowns worn by the women. The Speaker's salary is $\$, 5000$ a year, plus the house and large allowances for keeping it up. It is still the predominant opinion in England that the dignity of great offices of State should be adequately maintained.

And it is still the custom, the rule, even if a rule with exceptions, to appoint to these great offices men adequate to fill them. And when a great office like the Speakership is greatly held, as it is by Mr. Lowther, a new sense of its importance and its opportunities reinforces the old traditions. 


\section{CHAPTER XII}

THE FIFTH EARL SPENCER

FOR nearly five years Lord Spencer has been fighting a hopeless battle. Yesterday he died, and a great figure passes into history. I imagine there is no man who has known him who has not to-day a sense of personal loss. There can be no Englishman who does not feel that a great Englishman is gone. I must have written about him in times past, but I must write of him to-day out of many personal recollections of earlier days.

I speak of him as a great Englishman. Americans may think it a strong phrase, for, except during the three years of his second Irish Viceroyalty, his fame was not of a kind to fill the world. During that second Viceroyalty, moreover, American opinions must have been touched with some of the hatreds of the Irish Nationalists of those sombre days. He became Viceroy in 1882 , and on his entrance upon his great office, May 6, I882, Lord Frederick Cavendish and Mr. Burke were murdered in Phœnix Park, not far from the Viceregal Lodge and within view of its windows.

I have heard Lord Spencer tell the story. His entry into Dublin had passed off with no unhappy incident. $\mathrm{He}$ and his half-brother, Mr. Robert Spencer, since Viscount Althorp and now successor to the earldom, had ridden out from the Castle to the Lodge. From the windows or from the grounds, I forget which, they saw what they took to be a scuffle. Presently 
word was brought to the Viceroy that the Chief Secretary and the Permanent Under Secretary had been assassinated. They meant to kill Mr. Burke. They did not know who Lord Frederick Cavendish was, but since he tried to help Mr. Burke they killed him also.

It was an anxious moment, for it might well enough be that the murderers would aim higher still. Lord Spencer and Mr. Robert looked about them. There was not a soldier or policeman within call. There were no arms. Neither Lord Spencer nor his brother had so much as a revolver. Lord Spencer sat watching to see what might happen, and Mr. Robert explored the Lodge, presently returning with a steel poker from the library fireplace. There was nothing else. But the Lodge was not attacked. Brady and his fellowassassins were content with what they had done, and departed. It was rather late in the afternoon. The news soon reached the barracks in Dublin, and a force of cavalry was hurried off to the Lodge. But, for the moment, the thirst for blood had been slaked.

"Statesman and sportsman," says one English paper in its headlines, characteristically. In both capacities he had to hunt down the murderers. I am afraid there is no doubt that, though Mr. Parnell washed his hands of this stain, the Parnellites generally throughout Ireland were willing enough there should be a smear of blood on their flag. There had been many murders before; agrarian, political, and others. The adjective does not matter. They were murders. But the decd done in Phœnix Park had made it once more necessary to pass and enforce a Crimes Act. No less a man than Sir William Harcourt, then Home Secretary, introduced the Bill in the House of Commons. Mr. Parnell's abhorrence of the Phœnix Park 


\section{I36 ANGLO-AMERICAN MEMORIES}

murders, which hindered his policy, did not prevent him from opposing a Bill to prevent other murders; nor from withdrawing, with all his followers, as a protest against its passage. But passed it was on July I2, and Lord Spencer the next day proclaimed seventeen counties. Other murders followed-the Joyce family at Maamtrasna, husband, wife, son and daughter, all shot dead; Bourke and Wallace, shot dead in Galway; Blake, Lord Clanricarde's agent, and Kan, his steward, shot dead near Loughrea ; detectives in Dublin assaulted and Cox killed; Field, a juryman in the Joyce trial, stabbed. The intent to defeat the administration of justice was evident, and Lord Spencer put Dublin under martial law. Then Carey, who looked on while Brady and the other three hacked Lord Frederick Cavendish to pieces, turned Queen's evidence; Brady and Kelly and Coffey (who pleaded guilty) and Curley and Fagan were tried, convicted, and duly hanged. More than a year had passed since the murders. Six or seven months later Carey, the informer, was shot dead by O'Donnell on board the Melrose Castle in South African waters.

Such were some of the circumstances amid which Lord Spencer had to govern Ireland. But govern he did, firmly, wisely, effectively. He had Sir George Trevelyan as Chief Secretary, a very competent man, very devoted, but not, like Lord Spencer, of the governing type. Trevelyan was of the emotional type. Spencer's nerves were of steel. He used the powers which the Prevention of Crimes Act put in his hands with such effect that the number of of outrages was reduced by three-fourths. He was therefore reviled as no Viceroy had ever been reviled, nor has ever since been reviled, in Parliament and out. $\mathrm{He}$ took it all as part of the day's work. He never 
answered. He turned neither to the right nor to the left. He did what he thought his duty as well as he knew how to do it. Before or since Ireland has had no such Viceroy nor ever been more steadily ruled.

Let us take the testimony of Lord Morley, convinced Home Ruler and ex-Chief Secretary for Ireland, who is believed to have turned the mind of $\mathrm{Mr}$. Gladstone to Home Rule. Lord Morley says in his Life of Gladstone, Vol. III, p. 71 :-

"The new Viceroy attacked the formidable task before him with resolution, minute assiduity, and an inexhaustible store of that steady-eyed patience which is the sovereign requisite of any man who, whether with coercion or without, takes in hand the government of Ircland."

And there is just before this passage a picture of the condition of Ireland, "when the Invincibles still roved with knives about the streets of Dublin," with demoralization, moral cowardice, affecting even the courts in their duty, and " the very foundations of the social fabric rocking."

The worst and most desperate years in the modern history of Ireland. Not many men, perhaps, have lived for three years in hourly peril of assassination in a spirit as tranquil as Lord Spencer's. It never disturbed his work nor embittered his feeling toward the Irish. Of bitterness he was incapable; and of fear. Now that these dangers are past men may make light of them; especially those whose interest it is to relieve themselves of suspicion. But I will give you a single sentence of Lady Spencer, who remained by her husband's side and desired to share, and did share, the perils that environed him. Said Lady Spencer :

"I don't think I ever quite realized what the 
condition of things was till in driving out $I$ found that the aide-de-camp on the seat opposite me had his hand always on his revolver."

This, although there was always a mounted escort, beside police and detectives in front and in rear of the carriage. Such was the life they lived; such were the methods employed. The Irish, with their natural quick wit and gallantry, had named the Viceroy's wife Spencer's Faery Queen. But politics-it was always called politics-made no allowance for poetry.

All this did not prevent Lord Spencer from following Mr. Gladstone into the Home Rule camp in $\mathbf{I} 886$. It has been said that if Lord Spencer had held out Mr. Gladstone would have been forced to abandon or greatly modify his Home Rule Bill. However that may be, Lord Spencer's decision was a great surprise to the Unionists and a great blow, and they resented it with no common bitterness. They denounced him as a traitor. They resented it socially as well as politically. I met Lord Spencer one night at a house which, though of great importance and splendour, was a house where a year or two before he and Lady Spencer might or might not have been seen. A friend said to me :

"Do you see the Spencers?"

"Yes-why not?"

"You know as well as I do that it is the first time they have crossed this threshold."

"I know nothing of the kind, and if you ask Lord Spencer he will tell you you are wrong."

He did not ask, nor did I, but after a while I said to Lord Spencer :

"Well, it seems you do go out sometimes."

Half laughingly, but rather grimly, he answered :

"I go when I am asked." 
And after a pause :

"You know very well how angry the Unionists are; but would you suppose that we don't receive one invitation where we used to get twenty?"

"That's a rhetorical way of putting it."

"It is literally true."

I did not say so to Lord Spencer but I thought it almost as discreditable to the Unionists as I thought the Irish attacks on Lord Spencer discreditable to the Irish. I record one as I record the other, and in that spirit of impartiality at which I always aim, and to which I do not always attain. But this is a fine example.

Between a cancelled dinner-card and a shot from behind a hedge there is a certain difference; but there need not be much difference between the spirit which inspires the one and the other. If there were in all England two people who stood as near the summit of things as subjects can stand, they were Lord and Lady Spencer. Lady Spencer was a Seymour, greatgranddaughter to the seventh Marquess of Hertford. The first Earl Spencer was grandson to the third Earl of Sunderland, who married the daughter of the first Duke of Marlborough, and comes down through a line of ancestors distinguished in public and in private life. He was grandson to that Lord Althorp who, as Chancellor of the Exchequer, led the House of Commons 1830-4, and the two were singularly alike in those personal qualities which in this country confer upon the possessor of them an authority which mere talents never confer. The late Duke of Devonshire was another example, and perhaps the most illustrious of all. Side by side with him in point of character, absolute integrity, unselfish devotion to the State, and courage whether personal or 


\section{I4O ANGLO-AMERICAN MEMORIES}

political of the highest order, stands this fifth Earl Spencer. Yet this was the man whom other men, of position not less than his and of character heretofore spotless, set themselves to persecute.

I will take the late Duke of Westminster, the first Duke, as an illustration of the temper which at that time pervaded the Unionist ranks. $\mathrm{He}$ had been Marquis of Westminster till I 874, when Mr. Gladstone made him a Duke. He was a Liberal, a Gladstonian Liberal. In testimony of his respect and friendly admiration for his creator he commissioned Sir John Millais to paint Mr. Gladstone's portrait-the finest of the four which came from Millais's brush. In I 886 or I 887 the Duke caused it to be known that he no longer wished to keep the portrait, and he sold it, at a large profit, to Sir Charles Tennant, in whose house in Grosvenor Square it hung till Sir Charles died, and is now, I think, to be seen in Sir Edward Tennant's house in Queen Anne's Gate, with other canvases of distinction.

The Duke's next act produced an excitement even greater than the selling of Mr. Gladstone's picture. In I 887 he had asked Mr. and Mrs. Robert Spencer to dinner. Mr. Robert Spencer had lately married the Hon. Margaret Baring, second daughter to Lord and Lady Revelstoke. Then it came to the Duke's knowledge that Mr. Robert Spencer had been present at the dinner given by the Eighty Club to Mr. Parnell, and he withdrew his invitation. He was not deterred by the fact that the invitation to Mrs. Spencer had also to be withdrawn. In the vehemence of his hatred to Home Rulers, especially English Home Rulers, he was ready to inflict, and did inflict, this grave discourtesy upon a woman. There were other ways in which he could have avoided or evaded receiving 
Mr. and Mrs. Spencer, but he choose none of them. Even the Duke's friends, his political and personal friends, thought him wrong; and to explain his act he wrote a letter to Mr. Spencer, which convinced nobody of anything except that he had made one more mistake.

I do not think that Lord Spencer was insensible to these various evidences of hostility, but he showed neither concern nor resentment. He was too proud a man, and his pride was of a kind which made it impossible for him to enter upon any justification of himself. He needed none. But he would sometimes, when asked, let a sentence or two fall from his lips which might give you a hint, though they never seemed meant as explanations. Like so many others, he felt the magic power of Mr. Gladstone, and in answer to a remark about Mr. Gladstone's influence hé once said :

"If you have ever been alone in a room with $\mathrm{Mr}$. Gladstone for half an hour, you would not ask me why I followed him."

In point of fact, I had not asked.

\section{II}

Next to his Lord Lieutenancy of Ireland, Lord Spencer's services as First Lord of the Admiralty, from 1892 to I 895 , first under Mr. Gladstone and then under Lord Rosebery, were of the highest value to the country. He laid the foundation of the system under which the British Navy has attained its present power. $\mathrm{He}$ did it in spite of Mr. Gladstone, and in spite of Mr. Gladstone's ablest lieutenant, Sir William Harcourt. Mr. Gladstone, in truth, was not much 


\section{I42 ANGLO-AMERICAN MEMORIES}

better than a Little Englander. He was not willing, at any rate, to spend the money on naval defence which alone could ensure to England her control of the seas, and therefore her Imperial position. He allowed Sir William Harcourt, then Chancellor of the Exchequer, and in that capacity, like other Finance Ministers, parsimonious to the great spending departments, to assure the House in 1893 that the Sea Lords of the Admiralty were satisfied with things as they stood. Lord Spencer told Sir William Harcourt that unless that statement were corrected and adequate funds provided for the strengthening of the Navy he should resign. The Sea Lords reinforced that protest, and the Prime Minister and Chancellor of the Exchequer were confronted with the certainty that the Lords of the Admiralty, Civil and Naval, would resign in a body. They put country above party. Mr. Gladstone had to give way, and the Estimates of the following year were framed in accordance with the Admiralty programme. But it was one of the causes which led to Mr. Gladstone's resignation; none too soon.

I dwell no further on Lord Spencer's political career, except to say that he held many high offices; that his renown as a statesman grew steadily greater; that, though not an orator, he was one of the weightiest speakers in the House of Lords, and that, with the Sovereign and with the nation, he held a position of high confidence. Mr. Gladstone, had he been asked by the Queen to recommend a successor on his resignation in 1894, would have recommended Lord Spencer. But Lord Morley dryly remarks, "As it happened, his advice was not sought." The act of magnanimity, of patriotic forgetfulness of all differences between Lord Spencer and himself which Mr. Gladstone had in mind could not be performed. 
There came a note one day from Lord Spencer :

"If you will look in for lunch to-morrow there's something I should like to ask you about."

At that time Lord and Lady Spencer were living in Spencer House, St. James's Place. With the disadvantage of a confined entrance, and being, so far as approach to it and getting away from it are concerned, in a cul-de-sac, it is, nevertheless, one of the best houses in London. The west front looks out on Green Park and on Buckingham Palace in the near distance. Many of the rooms are fine, and there are fine pictures. The dining-room is on the first floor. Lunch over, we went to Lord Spencer's room. All the world knew that the great Althorp Library was to be sold. Few people, I think, knew that Lord Spencer had elected to sell it in order to reduce the rents on the Althorp property, and so relieve the farmers, hard hit by American competition and scarce able to make both ends meet, let alone the question of profit. Lord Dalhousie had done a similar thing on the Brechin and Panmure estates in Scotland, but such instances were rare and have not yet become frequent. Said Lord Spencer :

"I suppose you will be sorry to hear that the library is sold."

"But it was to be disposed of by auction."

"Yes; but I had an offer from a private buyer which I have accepted, and the books are now being packed for removal. You were so much interested in them that I thought you might like to know."

There was a moment's hesitation; then he went on :

"For the present I am not at liberty to tell you the name of the buyer nor the amount of the purchase money. But there's a matter on which I should like your opinion." 
Nor am I at liberty, nor shall I ever be, to repeat what Lord Spencer then told me about the circumstances of the sale. It became known presently that the buyer was Mrs. Rylands, of Manchester, on whom no blame of any kind rests, and the sum paid is believed to have been well over a quarter of a million sterling, and not far from a million and a half in dollars. Saying nothing about these matters, Lord Spencer briefly and very quietly stated the facts, and the reasons why he had not, in fact, received the whole of the purchase money, and asked me what I thought of the transaction as a whole.

"But you say the transaction is completed."

"Yes; it is."

"Then what is the use of asking me to advise you about it ? If you had applied to me earlier___"

"Ah, I supposed you would disapprove, and that is why I did not tell you at once. You probably think I had legal rights which I might have enforced."

"Yes."

"Well, I thought it all over and made up my mind I could not have a lawsuit about the library."

"Did you consult your solicitors?"

"No. I was afraid they would advise me to contest it, and you know one doesn't like to go to one's solicitors and then not act on their opinion. I have not told them, nor anybody but you. I thought I should like to see how you would take it."

Lord Spencer had a sense of humour which he was indulging at my expense. His eyes sparkled, as they often did; a gleam in them which could be only a gleam of humour. There was no use in remonstrating. The mischief was done. But I said what I thought, and my wrath seemed to amuse Lord Spencer still more. His conduct had been throughout that of a 
grand seigneur. He was that all his life through and in every circumstance of his life, but when it came to business matters and to dealing with large sums, it was to say the least, expensive. I said finally I could understand his wishing to avoid a controversy, but how could he submit to what he thought an unjust exaction?

" Don't you see, I had to choose? It had to be one or the other. I preferred to lose the money and endure the injustice."

Finally I said that while I would not pretend to give a legal opinion, I felt convinced an action could still be brought, on grounds I indicated, for the recovery of the money. But Lord Spencer shook his head.

"You are only proposing to me a lawsuit, and that I am no more willing to bring now than before."

We talked a little of other things, and before I said good-bye I asked what he meant to do about the empty bookcases at Althorp. An expression I can only call pathetic came into his face.

"I believe Lady Spencer is already buying more books. Will you help her?"

I did look over these new purchases from time to time. They served to fill vacant spaces but had noother interest.

Some time after that I heard of a sequel to the story. Also from Lord Spencer himself, and also after it was all over. The sum involved was very much less, but the impudence of the claim was even more flagrant, and this time I think Lord Spencer had been for a moment disposed to fight it. But he did not. It could not have been done without bringing up the whole matter, and bringing on the scandal he was resolved to prevent. Not once did he use a hard word about anybody concerned. It was not his way. He lived in the upper air. 


\section{I46 ANGLO-AMERICAN MEMORIES}

I had seen Lord Spencer in many circumstances; perhaps never before when the fine nature of the man shone out more clearly. He was describing what to most business men would have seemed a most unbusinesslike proceeding. He himself was quite aware that it would not stand the tests which men of the world commonly apply to such transactions. But he told his story with a simple dignity which was enchanting. He had no apology to offer. He said as Luther said, "I could not otherwise." Wise or foolish was not to him the point. He had to do it because he was Lord Spencer. On the strong, benignant face there was no expression of regret or consciousness of fault. There was no animosity against those who had wronged him. He was of those who thought it nobler to suffer an injury than to resent it. He made no professions, quoted no text, had no air of righteousness. He was a man of the world, and of the great world, who had chosen to do what the world, had it known, would have thought a foolish thing. He was content that it should be so.

I had seen the great library at Althorp more than once, intact. I am not going to describe it for there is no room and descriptions of it are not wanting. But $I$ saw it in such a way that I have always felt as if I knew the collection better than I did. The hours I spent there were hours of freedom. On the morning after I arrived at Althorp Lord Spencer said at breakfast :

"You shall have the keys and the place to yourself. But you will have to find what you want. I am sorry to say neither Lady Spencer nor I can be of any help. We know nothing about the treasures which have made the library famous."

The treasures were all in the one square corner 
room at the end of the south corridor. There were other books everywhere. All the passages and halls were lined with books, but they were for the most part books which no gentleman's library should be without. There are hundreds and thousands of such collections all over England, standard works, Parliamentary papers, histories, cyclopædias long since out of datemasses of volumes bought from a sense of duty and never looked into. Thousands of excellent books, none of distinction.

The books of distinction were in the square room. The Valdarfer Boccaccio was there, the buying of which at the Roxburghe sale, for a price then without precedent, Emerson himself has sung in prose. The Caxtons, the old Bibles, the Shakespeares, the rarities of many kinds which entitled the Lord Spencer of the time to think his the finest private library in the world, as it probably was, were all in this one room, in locked glass cases reaching to near the ceiling. In fine condition, as a rule, though the Boccaccio in its smart modern binding, with edges cut close, was a disappointment. It is so great a library that not even the greasy rhodomontade of Dibdin's sixvolume catalogue could degrade it. 'Toward lunchtime Lord and Lady Spencer came in, asked how I had been getting on, and looked at some of the books I had taken out and was going over. Lord Spencer took one into his hand, looked at it, opened it, shook his head, and laid it down almost sadly, saying:

"I care for the library because it was my ancestors' and is a part of Althorp, and a family possession. But I never could have learned to value books as books, even precious books like these."

There was a certain pathos in the words as there was in his manner. But he spoke the exact truth, 


\section{I48 ANGLO-AMERICAN MEMORIES}

because it was the truth, and he never in his life spoke anything else. In the afternoon we walked across the fields to Brington Church, the burialplace of Lawrence Washington and other Washingtons, whose inscriptions and arms are to be seen in the brasses and pavement stones of the little church.

"Your countrymen are always coming here," said Lord Spencer. "It is an American shrine."

I said: "Yes, if we have a saint in the American calendar, it is Washington." He considered a moment, and added :

"Well, after all, he was an Englishman."

I told him I had more than once heard Sir William Harcourt say that all the great Americans of that great period were English.

"True, but they were Englishmen who chose to be Americans."

An answer which would have pleased Harcourt and silenced him.

Long as Earl Spencer had been out of the public eye, the English evidently feel his loss, and feel that one of the truest Englishmen of his time and of all time is gone. The Irish themselves, the men, or some of them, who heaped hateful epithets upon him, and then, after he accepted Home Rule, heaped eulogies on him more hateful still, now pay him a homage which has nothing political in it. He passed outside of politics upon his wife's death. That was the end of everything for him. "I have lost allliterally all." The firmness of his character was shaken for the first time by that grief. With the strength of his character there was always sweetness, always beauty; always a noble conception of life, and he so lived his own life as to make his conception a noble reality. 


\section{CHAPTER XIII}

THE LATE VISCOUNT GOSCHEN-A VERY INDIVIDUAL ANGLO-GERMAN ENGLISHMAN

"A VIOLENT moderate man."

1 Such was the late Lord Goschen's description of himself. But he was not, in truth, violent, and not moderate. Otherwise the description is accurate.

Not violent, I should say, but contentious. Not moderate, but an opportunist, when he was not too stubborn. The epithets, one set or the other, have no particular value. A man is not to be summed up in an adjective; least of all a man whose life was public, who was everywhere to be met, who spoke in Parliament and talked without stint in private; who was long a Minister of the Crown, a man of business, of affairs, of very varied and substantial gifts. Character and achievement are what you judge by, in such a life as his. So judged, he stands rather high, if not quite so high as his invincible confidence in himself would put him.

To take the man of business first. I always thought his best eulogy came from the City. That is where the brains of finance are to be found. I have often asked, and I have always had the same answer. The great bankers and merchants of the City of London thought Mr. Goschen, as he then was, a first-rate Chancellor of the Exchequer, and did not think Mr. Gladstone first-rate. As for his conversion of Consols, reducing the rate of interest first to $2 \frac{3}{4}$ per cent 


\section{50 ANGLO-AMERICAN MEMORIES}

and then to $2 \frac{1}{2}$, the manner of the operation was reckoned masterly. Whether the result of it and the effect on public credit can be deemed favourable is another question. But it embedded his name in financial history, since reduced Consols have ever since been known as "Goschens." He went out of business rather early, his fortune seeming to him sufficient, and thenceforward devoted himself in one way or another to politics.

My acquaintance with Mr. Goschen stretched over a long period but was never in the least intimate. I used to meet him at dinners or at houses in the country. It happened sometimes after dinner, when the ladies had gone, that I found myself next Mr. Goschen, by no choice of his or mine. He was a man to be respected and was respected; and to be liked if you were built that way. But his idea of conversation was to plunge at once into argument. With me he often chose an American topic; thinking, apparently, that on American topics I needed enlightenment, as perhaps I did, and that it was his mission to enlighten me, which did not logically follow. Still, I thought it very good of him to try. His mental attitude was not unlike that of the late Empress Frederick, when, as I have elsewhere related, Her Royal Highness-then Crown Princesswas good enough to set forth at length her views on things American for my benefit and instruction.

None the less, there was a certain pleasure in listening to Mr. Goschen. He knew as much of America as most Englishmen of his time knew; perhaps more. But whether he knew much or little, listening to him was an exercise of the mind. He understood logic. Grant him his premise, and he led you step by step irresistibly to his conclusion. I used sometimes 
to wonder where he got his premises. The office he held brought him into no relation with the Government of the United States. In the English newspapers, at that time, the American news was meagre and trivial. No doubt Mr. Goschen's firm in the City had correspondents in New York, but information from that source would relate chiefly to the money market. Mr. Goschen, nevertheless, ranged over a wide American field. I must do him the justice to say that though he dogmatized he liked to be answered. He liked you, as the English generally do, to stand up to him, if only for the pleasure of bowling you over. Once I happened to say I agreed with him. Instantly he retorted :

"No, that is not what I want. Even if you agree with me you know the other side of the case, and that is what I wish to hear."

Again it might be that he wanted a statement of the other side in order to demolish it. No matter. His was the attitude of a man who desired to get at the truth, and, if he did not think the truth attainable otherwise, then controversially. His desire to get it somehow was laudable. It remained laudable even if by and by you came to see, or to believe, that he thought the true home of truth not at the bottom of a well but in his own head. A good many people think the same of their heads. Said Mr. Goschen once :

"Well, the truth must be somewhere, and truth is not a matter of opinion but of fact."

"Mr. Ruskin said the same thing of art," I answered, well knowing he did not regard Mr. Ruskin as an oracle, and eliciting the retort I hoped for :

"Why do you quote Ruskin to me and what has art to do with the question we are discussing ?" 


\section{I52 ANGLO-AMERICAN MEMORIES}

There you saw the man's habit of mind. He fastened upon his subject. Nothing could divert him from it. No illustration, no analogy, was to the point. He kept as rigidly to the proposition he had laid down as Euclid to his geometrical demonstrations. Early in life he-I mean Mr. Goschen, not Euclidwrote a book on The Theory of the Foreign Exchanges. Exchange, that is, in the financial sense of the word. I have never read it, and am quite sure I should not understand it if I did. But I have been told that from beginning to end it is a chain of inseparable links. He writes on this abstruse subject with mathematical precision. I should be very much surprised if he did not.

The one impossible subject was Free Trade and Protection. He had in the highest degree the intellectual arrogance of the confirmed Free Trader. He knew perfectly well that the whole world, England excepted, was Protectionist, yet he could not discuss it unless in a tone which implied contempt for the Protectionist. Yet he did his best to be polite, in the beginning.

"I suppose you, like all intelligent Americans, must deplore the Protectionist policy of your Government."

"No, I am a Protectionist, and if you make belief in Free Trade-your kind of Free Trade-a test of intelligence in the United States, there are not more than half a dozen intelligent Americans, and they are college professors."

$\mathrm{He}$ was a man to attract attention anywhere. Tall, strongly built, the shoulders powerful, a little rounded and with a just perceptible stoop, his head bent, as often happens to men who have a weight of brains to carry. The features were largely moulded, 
and he had such a look of the Jew in him that he thought it desirable to deny that he was of Jewish descent. Hebraic he was not, but Teutonic. His abrupt manner showed that. Plainly a personage; but more impressive than sympathetic. His shortsightedness took from his appearance and put him at a disadvantage. The steadfast gaze was lacking. He peered out upon the world. But he bore this misfortune, as he bore other things, with a philosophy which strove to master an impatient temper, and sometimes succeeded. In a country house known as South Hill Park, where I sometimes met him, was an oak staircase, the oak steps polished and uncarpeted; treacherous even to good eyes. Goschen clung to the hand-rail as we went down, and at the bottom said :

"Every time I descend these stairs safely it strengthens my firm belief in an overruling and beneficent Providence."

Not without reason was he grateful, but a spice of danger was welcome in a house of peaceful beauty, where attractions of many kinds abounded; Lord and Lady Haversham being two.

As a speaker Lord Goschen had two physical defects. He was extremely near-sighted and his voice was harsh. An orator-which he never was, though a good debater-needs to be able to watch the faces of those to whom he is talking. If he cannot do that, he cannot judge of the effect he is producing; the expression of the features being far more significant than applause or audible dissent. As he could not see these expressions, he could not vary his speech to suit the mood of his audience, as all great orators do, since oratory is an appeal, and by no means a spoken essay. His voice was so 


\section{I54 ANGLO-AMERICAN MEMORIES}

thin and raucous that you had to forget it in order to open your mind to what he was saying; nor was his bearing good, or his manner. He seemed never to care to persuade, but only to convince; which is fine from the moral point of view but ineffective on the platform or even in the House of Commons. In neither place do you get a fair hearing for your arguments unless you first win the sympathies of your hearers.

The same defects impaired the effect of his conversation, though perhaps in a less degree. As he talked, the eyes narrowed in the attempt to see clearly; the brows knitted; the features were distorted, and the voice was rasping. Charm of manner he had none, though I believe when you knew him well his character had the charm which springs from sincerity and from unusual mental powers; if indeed that be charm. All the same, you felt you were in the presence of a masterful personality with abilities equal to any post; with a record of great and various services equalled by few men of his time. He had been First Lord of the Admiralty as well as Chancellor of the Exchequer, and special Ambassador to Constantinople in a formidable crisis. He had declined the Speakership-where he would have been out of place-and the Viceroyalty of India. The flowing tide of Democracy was not strong enough to carry Goschen with it. He stood on the bank and watched the surging of the torrent seaward, bearing, as he thought, destruction with it. Because he adhered to the convictions which Mr. Gladstone had abandoned he was not asked to join Mr. Gladstone's Cabinet in I 880. All honour to him. Mr. Elliot, whose rather mechanical and almost impersonal Life of Goschen has lately appeared, quotes from a talk between 


\section{THE LATE VISCOUNT GOSCHEN 155}

Palmerston and Goschen a sentence of fire. Palmerston had told his young colleague he need not trouble his head at present about domestic reforms. The book was closed-for Palmerston.

"But you will soon have Gladstone and then you will see strange things."

He did see them. We all saw them, and it was Mr. Goschen's high task to lead the Liberal revolt against Mr. Gladstone's Home Rule policy of I 886 ; while Mr. Chamberlain was still weighing chances and considering compromises, and while Lord Hartington was making up his mind; always with him a slow process.

And when Mr. Goschen, because Lord Randolph Churchill forgot him, became Chancellor of the Exchequer in Lord Salisbury's Government, he had already founded the Unionist Party, and had become, as Mr. Garvin well describes him, " a sort of living link between the Conservatives and their new allies, and an inspiring agent in giving moral unity to the coalition." If Lord Randolph " forgot Goschen," it is certain that Mr. Gladstone never forgave Goschen; no, nor any of the other great, true Liberals who forsook their leader rather than forsake their principles. In the Grand Old Man-how that phrase, once in all mouths, has passed out of use!--was also a vindictive old man. You opposed him at your peril. But not for one moment did Goschen hesitate. If all else be forgotten, that act of wise courage will preserve his memory. 


\section{CHAPTER XIV}

MR. GOLDWIN SMITH, SCHOLAR, APOSTLE, HISTORIAN, WRITER OF ENGLISH

I his original form Mr. Goldwin Smith was a survival of the Renaissance. He was born out of due time. By nature he was a scholar, which is a contradiction in terms but true. He was in truth a scholar of many accomplishments-the Humanities, History, Political and Economical Science, and much else. You could imagine him living his life in an Oxford quadrangle, quite happy and quite useful in a way; in the way of the quadrangle. But there was another Goldwin Smith, a kind of apostle, with a message from on High to preach the Gospel. That is the Goldwin Smith the world knew for near sixty years.

Yet the Gospel he preached was his own, and not always the same. Moreover, from time to time the original Goldwin Smith reappeared, as it did at Cornell. That was after he had endured a period of disappointment.

But the impression he left after many years of acquaintance was the same. We met, not frequently, but always on exactly the same terms. He wrote to me, not frequently, yet in the course of years a large number of letters; all exactly alike. We were friends, but never said anything about it. His letters began, "My dear Smalley," and plunged at once into the discussion of the topic at that moment 
uppermost in his mind; or of the matter in which he thought I might, as a journalist, be useful to him or to his scheme. They ended not less abruptly. Within four pages he would have stated his case with the force and clearness he used in print; then without a word of transition, "Very truly yours, Goldwin Smith." At one time he wrote much about Canada and her relations to the United States, and the inevitability of her annexation by the United States, for commercial if not political reasons. $\mathrm{He}$ was surprised that $I$, as an American, did not share his views, but he never tired of stating and restating them, until finally he either abandoned them himself or became convinced that neither in Canada nor in the United States was there any important party of his mind.

I kept these letters, and if I could get leave from his executors would print them, or some of them. But I am under no temptation at present to do it without leave, for they are all locked up with a great many more not less valuable, in a safe deposit vault in New York. And I have not the courage to disturb them.

When we met, much the same thing happened as when we wrote. A word or two, perhaps, of greeting, and then to business. I used to think it a pity his interests were so many. As he could not deal with them all exhaustively he dealt with most of them fragmentarily. He became a journalist. He wrote no matter where, and on whatever subject had him at the time in its grip. The Bystander, which he founded and supported, never, I think, had a large circulation, nor ever much influence except of a secondary kind; often the most important of all. I mean that he reached the minds of other writers and editors, and of many who were neither but read 


\section{I58 ANGLO-AMERICAN MEMORIES}

this queer sheet in order to know what Goldwin Smith was thinking about. No medium of communication with the public was too insignificant. When he used it it ceased to be insignificant.

He did much for Oxford. He did much for Cornell. His multifarious activities were likely to be productive whether they seemed to be right or seemed to succeed or not. For his was a fertilizing mind, and stony indeed must be the ground where what he sowed would not take root. But if I am to single out one service he did I should take $\mathcal{T}$ be United States : An Outline of Political History, I492-I87I. He meant it chiefly for England. But it happens to be the best history of its kind there is, whether for Americans or English, and it was the first history in which the anti-English prejudice which disfigures most histories by American writers had been omitted. The good example has since been followed, but it was Goldwin Smith who set the example. It is, moreover, a masterpiece of narrative. The author was for so many years accused by Canadians of being too American that to Americans he cannot but be known as a friend. Yet let me quote a sentence from the Preface to this History :

"If it comes into the hands of an American, his liberality will make allowance for the position of an Englishman who regards the American Commonwealth as the great achievement of his race, and looks forward to the voluntary reunion of the American branches of the race within its pale, yet desires to do justice to the mother country, and to render to her the meed of gratitude which will always be her due."

That was dated in 1893 , five years before England's refusal to join the European coalition in favour of 
Spain and against the United States taught us that England was our friend.

One thing more. Goldwin Smith never lost his distinction as a writer because of his continuous immersions in journalism. $\mathrm{He}$ is a lesson to us all. The lesson is there but the learners are never too many. Perhaps the coldness of his temperament helped him. In none of his handwriting that ever I saw was there a trace of hurry or of impetuous feeling. The stream was full but did not overflow its banks. For his style I go further back than the Renaissance. He had something of the purity of the Greeks; the simplicity, the absence of emphasis, the total neglect of the superlative and the intensive adverb. I do not know whom of his contemporaries to put above him as a writer, nor whom to put beside him. In the measured and melodious flow of his prose, in its restrained force, in the beauty of its grave cadences, in its purely intellectual quality and, as a rule, in its distinction, he stands by himself. He could hit very hard, and often did, but there was something judicial in his anger ; it was not passion, but a process of the mind.

In his melancholy quarrel with Disraeli it was Goldwin Smith who began. His criticisms upon the great Tory were acrimonious because they took no account of circumstances nor of differing points of view. When Disraeli replied by calling his critic a parasite, the reply was neither apt nor damaging. But it angered Goldwin Smith, whose message from beyond the Atlantic about "the stingless insults of a coward" was no better than Disraeli's taunt. The Tory leader could strike blows that hurt when he cared to, but he often contented himself with an exprcssion of contempt, almost always a cheap 
retort because not often sincere and still less often energetic. That seems to have been all he meant to suggest when he remarked : "I am told I am pursued in the public press by an Oxford Professor named Smith."

If the Oxford Professor had political ambitions, as he had, a wrangle of this sort with Disraeli was not the way to promote them. But there were other reasons which stood in the way. Two things darkened his life and changed its course. The first was his failure to win the Oriel fellowship on which his heart was set, and the success of his rival Dean Burgon whom he called a buffoon, as perhaps he was. It may seem no great matter, especially as he did secure a University College fellowship, and as his Oxford career was starred with scholarships and prizes, and later he became Regius Professor of Modern History at Oxford. But he was profoundly chagrined and he did not conceal his chagrin. He carried it with him across the Atlantic; it was one of the causes which drove him into exile. The second of the two tragedies was the insanity of his father, a doctor in Reading, Berks; and the dread lest a similar fate might be his; happily a groundless dread. But it is easy to understand that a man pursued by such a phantom as that might shrink from the collisions of public life.

During visits to Canada I used to hear Goldwin Smith discussed in varying tones. The fact that he took Cornell on his way did not predispose the Canadians to like him. Were there not universities in Canada, and was not an Englishman's first duty to his own country and her outlying provinces? Then came his theory of Canadian absorption by the United States, which Canada hated, and from 
hating the theory to hating the author of it was no long step. By and by the theory was relinquished, and the theorist became popular on quite other grounds, and remained so. There grew up an affection toward him. His choice of Canada for his home lent distinction to the Dominion, and his life was filled with proofs of devotion to the land in which he had chosen to dwcll. But now, since his death, comes the gift of his fortune to Cornell, and this, naturally enough, is resented. Why should an Englishman endow an American college? But the Englishman had spent a great part of his life in trying to abolish some of the barriers between English and Americans, between what he always regarded as two halves of the one British race. He had other enthusiasms, some of which he kept in cold storage and took out as they were wanted. But they were enthusiasms still.

The Englishman to whom Goldwin Smith seems nearest akin, intellectually and personally, is Lord Morley. Yet instantly contrasts present themselves, and the contrasts seem sharper than the likenesses. Lord Morley long had in him, and still has, not less of the ascetic than Goldwin Smith, yet this did not prevent him from entering public life and making himself a great place there, which he still keeps. The asceticism was somehow consistent with a real sweetness of nature and a real sympathetic concern in the interests of others. He left journalism, as Lord Milner did, for politics, high politics, and for years he governed 290,000,000 of Oriental subjects of the Crown. He had laid aside so much of his early Radicalism as would have made his Secretaryship of India a disaster. He did not apply to the government of the great military dependency of India the principles of Mr. Keir Hardie or of our great 


\section{I62 ANGLO-AMERICAN MEMORIES}

Mr. Bryan, who based his eight columns of criticism upon English rule in India on the ignorant belief that India is a colony. Lord Morley, in short, is so constituted that he is capable of compromise, and has that practical side to his character which has made him a very able, very useful, very sensible Cabinet Minister. If I were to enter upon a parallel between him and Goldwin Smith I should have to leave out all that. The parallel between them lies in their intellectual qualities, their capacity for scholarship, their unswerving loyalty to ideals, and in each a touch of something like fanaticism; in Lord Morley his "sombre acquiescence" in the ferocities of the French Revolution, and in Goldwin Smith his long-cherished but academic faith in the readiness of the Canadians to cease to be Canadians. 


\section{CHAPTER XV}

PRINCE FRANCIS OF TECK

TO the late King he was always " My dear Frank." Frank."

To the German Emperor he was "My dear

To the present King and to the Queen, whose brother he was, he could hardly be anything else.

But to his friends and to many who were hardly more than acquaintances he was "Frank" and "My dear Frank." Which is equivalent to saying that he was a very popular man: as he was. He was not a Royalty, but he stood upon the steps of the Throne. It is a difficult position. His mother, the late Duchess of Teck, was one of the best-liked women in England; also in a difficult position. His father, the Duke of Teck, had a kindliness of manner, and therefore presumably of nature, not always, though often, found in Serenities.

The English people have had a long apprenticeship in such matters, but these German titles never come very trippingly off an English tongue; nor are the things they represent a natural outgrowth of English life. Inextricably interlaced as they are with what is purcly insular, they are accepted but they are not welcomed for their own sake. The welcome depends on the character of those to whom their German distinctions belong by birth. It adds to the perplexity of the average Englishman when he finds a Prince, who on one side of him is English, inferior 
in rank to a Duke. Prince Francis of Teck was a second son. His elder brother is Duke of Teck. There is a third son, Prince Alexander. Their mother was sister to the late Duke of Cambridge and cousin to the late King.

I must use the word popular, with reference to this family, over and over again. The Duchess of Teck had a popularity of a very remarkable kind. She laughed her way through life. It was perhaps for her the easiest way of getting on, for she was very stout and did not like walking. A genial, cheerful, sympathetic soul. Her daughter, the present Queen, was popular as a girl. When the late Prince Eddy, the late King's eldest son, asked her to be his wife and she consented, all England applauded. It was not a brilliant match. The Heir to the Throne of England might be expected to mate with the best Royalty there was on the Continent, but brilliancies of that kind are not what the English people care most for. They liked this girl. They liked her fresh face and pretty manner and her friendliness. At a garden party at Marlborough House she appeared on the terrace after the gardens were filled, and stood there a moment looking down on the scene. There was something like a murmur of admiration; the nearest permissible approach to applause in the circumstances. The Queen was present, sitting under a tree, and noticed it and her sad face brightened. Mr. Gladstone was there and took note of the incident for his own purposes: his face wearing the look of instantaneous concentration often seen in the House of Commons when debate took an unexpected and personal turn. When Prince Eddy died it was thought right that his younger brother, Prince George, should succeed him as suitor to Princess Mary of Teck as well as in his 
heirship to the Crown. And so it happened that the Princess, more often called Princess May, came to be Queen of England; and is loved as Queen by her people, who loved her as Princess May.

If I were writing of a death which had occurred a hundred or two hundred years ago, I might say:

A King and Queen stood by his bed; visited him during his last illness; were with him when he died, and mourn for him now that he is gone. They were the King and Queen of England.

To many a loyal subject that would be something more than a consolation in his last hours. To Prince Francis it could only have meant that the Queen was his sister. Family ties are strong in this Royal Family. It is one of the reasons of the hold they have upon the affections of the people of England.

There are critics who say that Prince Francis might have been saved. He would not have been ill had he not gone to Balmoral before he had really recovered from the operation on the throat of three weeks before. He was not well enough for the return journey, but it was a choice between that and staying on in a climate which, to him, had become deadly. Once here, and in a nursing home in Welbeck Street, pneumonia had mastered the patient. His was the kind of constitution, robust and of abounding vitality, in which that malady plays worst havoc.

Moreover, it begins to be said that in respect of certain maladies Continental methods of cure are more efficient than English. The late King's was a different and more difficult case, but there were plenty of doctors in Paris and Berlin who thought, and said, that he ought not to have been allowed to dic. I have heard here in London the same remark on Prince Francis of Teck. But that is a purcly 
Continental view. The Prince had the best treatment England could give him.

Prince Francis was a soldier and a good officer. He had served in India, in Egypt with Lord Kitchener, and in South Africa; ending as brevet-major in the Ist Dragoons with a D.S.O. and the Queen's Medal with three clasps. I was talking last night with an officer who had served in South Africa with even greater distinction than Prince Francis. $\mathrm{He}$ said :

"There was this about Francis Teck. He could get men to do things that other officers could not. He was careless about danger. He had a great power of work and an organizing ability, and looked after his men thoroughly. That is the kind of officer for whom men will do their best."

He looked it. He was a soldier all over; tallI should think six feet-well set up, powerfully built, with an air of command which in private he tried to suppress but could not quite. He was one of the bignosed men whom Carlyle respected; but the rest of the features were in proportion, and the impression of energy was not restricted to any one feature, but came from the whole presence of the man.

I met him oftenest at a certain club where many kinds of persons are to be met, most of whom have some title or other to distinction; not all, because every club has its mistakes. Wherever you met him he was the same. A great suavity of manner and a great energy of manner at the same time; perhaps an unusual combination. The more a man bored him the politer he would be. Into whatever occupied him for the moment he put his whole soul. He would not talk to you about it unless you were interested and asked; then he would pour out details. He had 
devoted himself to setting up an Automobile Club on a great scale, and now the club building lifts its fine façade in Pall Mall, a monument to the enthusiasm and administrative capacity of the Prince.

It is a monument also to something else. I once asked Prince Francis how he had managed to get his club built so quickly, so much more quickly than is usual with important structures in this country. He said :

"I hoped you would ask me that. It has been built in this short time because I sent to America for American foremen and put them in charge. The credit is due to them."

"Did they get on well with their English workmen and the English workmen with them ?"

"I have never heard a complaint from either. Moreover, the work has been done not only quickly but well and solidly; no building more so."

It covers nearly the whole of the site of the old War Office, and is, or soon will be, the last word, at any rate on this side of the Atlantic, in luxury and conveniences and variety in club life. Prince Francis himself was in one thing American; he had an open mind and did not reject a novelty because it was a novelty or had no precedent. What will happen to the club now that he is gone is a question. It has, I believe, five or six thousand members, and contains two hundred bedrooms, and almost everything you can think of except a race-track for motors.

He was chairman of the Middlesex Hospital; the same hospital to which Sir Henry Morris was Consulting Surgeon. Of his work as chairman I hear the account I should expect. He mastered the whole business of hospital government, gave time without stint to his duties and was a devoted, inde- 
fatigable, intelligent executive. It is the chronic condition of all London hospitals supported by voluntary contributions to be in debt. The Middlesex owed $f_{2}, 0000$ which it had no means of paying. Prince Francis set to work and in three months or so raised the whole amount; begged it from the public. Then, instead of resting on his laurels, which is not what laurels are meant for, he proposed to raise another larger sum to put this great hospital on a selfsupporting basis. And then death came.

Prince Francis had a generous side to his energies, even in little matters; he liked doing kindnesses for others. Little things or big, the spirit was the same. When Mr. Bourke Cockran was in London last year he brought his automobile with him. He was going to the Continent; and to take an automobile with you from England to the Continent involves some rather technical arrangements with the customs and other authorities. Neither Mr. Cockran nor his chauffeur knew exactly what to do. We went upstairs -this was at the Ritz Hotel-to call on an English lady, a brilliant being who lives in New York, and there we found Prince Francis. When he heard of the automobile difficulties, he said at once:

"Why, that's in my jurisdiction. That's what the Royal Automobile Club exists for. Give me the facts and I'll arrange it all for you."

Mr. Bourke Cockran was a stranger to him but that made no difference. Turning to his hostess, he asked if he might use her telephone, called up the secretary of the Automobile Club, told him what was wanted, asked him to see that the formalities were attended to, and ended with a characteristic sentence:

"Please understand, the details I have given you are all you need. Do not trouble Mr. Cockran, but 


\section{PRINCE FRANCIS OF TECK 169}

arrange so that when he arrives at Dieppe he shall find his motor waiting for him, ready to start for Paris, and his papers all in order. The chauffeur will have funds for all expenses. You quite understand? Thank you. Good-bye."

He dies at forty, but in his forty years he has lived the full measure of ordinary lives. He departs amid such expressions of grief and affection as attend a man to his grave, not because of his position or relations, but because he was a man. 


\section{CHAP'TER XVI}

LORD PAUNCEFOTE AS ANGLO-AMERICAN AMBASSADOR

\section{I}

I HOPE nobody will misapprehend the meaning of Anglo-American as applied to a man who was British Ambassador first, last, and all the time. No man ever stood more stoutly on all occasions for his country's interests and rights. But what I mean is that, in the long run, Lord Pauncefote's rectitude and sense of fairness, of justice, of friendship as the first policy of the two countries, inured to the benefit of both. In that sense he was Anglo-American. Of that his friends on both sides may be proud, and for that we Americans have every reason to be grateful to this Englishman.

Lord Pauncefote was a great Ambassador, and as such my memories of him are abundant. So are they of the man himself, and I hardly know which of the two ought to have precedence. But the truth is they cannot be separated, since he could not have accomplished what he did as Ambassador had he been any other than the Sir Julian Pauncefote who first came to Washington to represent his Sovereign and country as Minister Plenipotentiary. Moreover, at the end of his thirteen years' service it was hard to say whether England or the United States was most in his debt. 


\section{LORD PAUNCEFOTE}

That could be said of few diplomatists, and it is perhaps because he was not primarily a diplomatist that it can be said of him.

It sounds like irony to admit that when, in I889, Sir Julian Pauncefote was appointed to be Her Majesty's Minister in Washington the appointment was sharply criticized. But it was mainly because Sir Julian was not in the direct line of diplomatic promotion. His training and life work had been largely that of a lawyer and judge; then he had been brought into the Foreign Office which had not been treated until of late years as a stepping-stone to diplomatic preferment. The men who were pushed aside to make room for him not unnaturally complained. But of such complaints Lord Salisbury, then Prime Minister, took little heed. He was in search of a man who could do the work, at that time far more anxious and difficult than now, which he wanted done. Had there been such a man among the Ambassadors or Ministers then available, that man would probably have been sent; but there was no one. I do not think we have ever done full justice in America to Lord Salisbury in his relations with the United States. What he most cared for was to promote a good understanding between his country and ours. He thought Sir Julian the man best fitted for that task, and therefore made him Minister. Never was a happier choice; never one which more signally evinced Lord Salisbury's judgment of men.

On the morrow of this nomination Lord Rosebery said to me :

"Of course you know Pauncefote?"

"No; I have never met him."

"But you should know him; now that he is going to Washington you must know him. Come to lunch 


\section{I72 ANGLO-AMERICAN MEMORIES}

to-morrow and I will ask Pauncefote, and you two can have a talk."

That is one more of the many kindnesses I owe to Lord Rosebery. He, who had been Foreign Secretary, understood better than most men the value, or rather the necessity, of personal acquaintance with diplomatists to whom a journalist has to stand in some sort of relation.

"Besides, you will have to say something about Pauncefote in 'the States,' where I suppose he is little known, and it is desirable you should meet him for that purpose."

The morrow came and with it Sir Julian Pauncefote, at 38 Berkeley Square. He entered the receptionroom next to the lesser dining-room with an air I thought uncertain; perhaps only the air of deference which a new Minister Plenipotentiary might naturally assume to an ex-Foreign Secretary of renown. His manner had about it a certain formality also; it came near being stiff. He knew he was to meet a journalist, and I dare say that put him a little on his guard. To the official mind an unknown journalist is an object of suspicion. Besides, he was on trial; he was new to his new position, and previous experience gave him no great confidence.

All the same, he was impressive. His fine, powerful head rose well out of his broad shoulders, and the whole figure had power if not authority. He was already bald but that only served to show the full outline of a well-balanced head. It was plain to see that inside it was a brain which was used, and had all his life been used, in serious work. There was a slight stoop; the shoulders not quite square; as of one long accustomed to bending over a desk. The blue eyes had a student look in them; the mouth lacked 
decision. I thought him in that first moment less a man of the world than of books and courts. $\mathrm{He}$ looked at you, or down on you, as if from the bench where he had sat so long; and though a judge has in this country, if not always with us, the authority of a ruler in his own dominions, that authority does not reach beyond the four walls within which he is supreme.

You expect, first of all, from a diplomatist suavity, tenue, and a manner of conciliation. Sir Julian had none of all that. He was rigid, self-contained; courteous, certainly, and even cordial, yet with the remoteness of a man engaged at that moment rather upon the solving of a legal problem than upon adjusting a new social relation. The stamp of diplomacy most marked was his reserve, yet even that was not really the trait of a trained diplomatist. A trained diplomatist is reserved while appearing open; one who has the air of telling you everything and yet tells you nothing; who seems to go with you all the way, yet advances never an inch beyond the line he has drawn for himself. I take it few men have this finish of deportment save those who have spent their lives in acquiring it by the daily and yearly practice of those arts which are to be learned only in the actual exercise of diplomatic functions. A man exceptionally gifted may attain to that distinction without experience, but such men are rare, and Sir Julian certainly was not one of them.

Nor can the lack of early training, or of the qualities which sometimes are a gift of nature at birth, often be supplied later in life. What Sir Julian was, or what he seemed to me, on this first acquaintance, he remained to the end. He was never a diplomatist in the drawing-room. He never acquired the small 


\section{I74 ANGLO-AMERICAN MEMORIES}

graces and social dexterity of a man who begins as attaché and climbs through long years to the top of his profession.

But he became the greatest Ambassador England ever sent to the United States. He was so great that it matters little whether he grafted upon the parent stock of sterling character and qualities the flower and foliage-bearing scions that ornament the trunk in which flows the sap that vitalizes the tree. I will give you later one brilliant example of his unfitness to contend with colleagues who practised, upon him or against him, the artifices by which a diplomatic expert thinks it permissible to entrap an opponent.

So new was Sir Julian to his new post that during all this lunch he felt his way. Every sentence had the air of having been considered. Not one was allowed to pass his lips except as a second thought. Lord Rosebery noticed this and tried to give a freer course to the talk, but could not. I do not think I was the obstacle, for later, as we walked away together, Sir Julian poured out his soul. His delight in the life now opening before him flowed freely into words. His talk became spontaneous and his mood confiding. I was so much encouraged by this that presently I told him I thought it might be for the interest of his mission if, before he landed in New York, the Americans were allowed to learn more about him than they yet had. Without knowing it I had struck the right note. It was the interest of his mission and not his own which he cared for. He said :

"Yes, your people cannot know much about me; nor can even the President or your Secretary of State, with whom I am to do business. If you think an account of my official life would help, I will give you the material, to make such use of as you think best." 
I am quite certain no such idea as this had occurred to him before, and he certainly had no conception of what he might be called upon to face in the way of publicity on his arrival in America. I can imagine that journalism, as such, was not what most appealed to him. But he saw quickly that it might have uses, and was perhaps readier to avail himself of them than if he had served a long apprenticeship to diplomacy in European capitals. I warned him I should send an appreciation as well as the facts. In short, I think he saw that an introduction to the American people through The New York Tribune would be as likely as anything else to put him on good terms with them and with the official world in Washington. He gave me the material, I wrote the letter, and $\mathcal{T}$ be $\mathcal{T}$ ribune published it.

As I did not leave London till I895, I saw little of the new Minister before that date. But when I went to New York for $\mathcal{T}$ be $\mathcal{T}$ imes I saw much, in the way of duty and otherwise. He had then been six years Minister and, after I 893, Ambassador. Yet his natural simplicity and kindness of heart had survived this experience, and when he heard I was going to Washington on a visit he asked me to stay at the Embassy. I should have liked nothing better than to be his guest, but I thought it would not do ; either for him or for me. An Ambassador cannot afford to keep a tame correspondent nor can a correspondent afford to be tamed, or to be under any but inevitable obligations to anybody. The inevitable are more than enough. I explained to him that as his guest I should put myself under an obligation, and that as $\mathcal{T}$ he $\mathcal{T}$ imes representative I must be, first of all, independent.

"I may have to criticize you and I cannot do that from under your roof." 


\section{I76 ANGLO-AMERICAN MEMORIES}

He thought I was very stiff about it, but assented. There grew up between us, none the less, a friendship which lasted, unbroken and uncheckered, to the day of his death; and lasts still. During the Venezuela negotiations I came very near to offending himperhaps did offend him, since some of these negotiations were unofficial, and were transacted outside of the Embassy and, for a time, without the knowledge of the Ambassador. But his was too large a nature to quarrel or take umbrage on a point of etiquette. He never made any other than an indirect allusion to my relations with Mr. Olney, nor do I suppose that he ever knew the whole truth. There was no reason why he should, nor do I believe for a moment it would have troubled the friendship between us if he had. Whatever he knew, that friendship went on strengthening. I was indebted to it and to him in many ways. I cannot acknowledge that too freely. Then there came an hour when, thanks to his confidence and to my connection with $\mathcal{T}$ be $\mathcal{T}_{\text {imes, }} \mathrm{I}$ was able to repay my debt in part, and to do him a service. Debt and repayment are, at best, but conventional terms, and not quite apt. We were friends, that is enough; that covers the obligations on both sides, and I shall speak of them as acts of friendship; as acts arising partly from mutual regard, but, on Lord Pauncefote's side, first and always from public duty.

II

In these days when Arbitration, thanks to thePresident first and then to Sir Edward Grey and Mr. Balfour, is passing out of the hypothetical into the practical stage, it becomes us to keep in mind what we owe to those who led the way. The first treaty of general arbitration 
between England and the United States was the work of Lord Pauncefote and Mr. Olney. They had legal minds, learned and full, from which the spirit of contention was absent.

They worked together in harmony. No two men were more competent to frame such an agreement. If it was not an agreement for unlimited arbitration, it went as far as the public opinion of that day would follow; and further. No treaty can be made to-day without reference to this. It was built on recognized principles of international jurisprudence : a science which both Lord Pauncefote and Mr. Olney had mastered; at different dates. The Senate wrecked it -a body of legislators ever more jealous of its usurped prerogative than careful of those international interests with which America is more than ever bound up. But the names of these two men are to be honoured and their services gratefully recognized whenever the word Arbitration is pronounced.

From the final blow struck by the Senate, a blow below the belt, Lord Pauncefote never recovered. It shattered his most cherished ideals. It shortened his life. But the treacherous hostility of the Senate cannot blunt the memory of the two nations of whom he was the benefactor. It remains to us to hope that the Scnate of to-day may be inspired by better purposes and abandon once and for all its rôle of obstruction and destruction and earn a better name than that of the graveyard of treaties. The sins of the past cannot be forgotten. Rightly remembered and aptly recalled, they may become the stepping-stones to good deeds in the future. But the pressure of an overwhelming, an overmastering, public opinion is still needed. Senators have defied it in the past. They cannot withstand it for cver. Defiance is no mark of 
statesmanship. The Senate is an entrenched camp, but the people of the United States are an irresistible army.

Lord Pauncefote, I must add, was to a certain extent personally unpopular with Senators. Often as he had been urged to make himself persona grata to those mighty men, often as he had been assured that it was even a diplomatic necessity, he would do nothing to win favour with a body to whom he stood, as he thought, in no diplomatic relation. He governed his conduct to Senators, as he governed his conduct to all men, by rules of uniform courtesy and good will. Tribute or homage he would pay neither to them nor to others. He was the representative of his Sovereign, and sovereigns do not crook the bended knee to those about them. Senators thought his simplicity and friendly independence a rebuke to their pretensions, and resented it. I do not say that such motives influenced Senatorial votes on great questions of public policy. But they created an atmosphere in that august chamber the breathing of which did not make for the easy ratification of treaties which bore Lord Pauncefote's signature.

This first treaty of arbitration is Lord Pauncefote's legacy to us. We owe it to his memory and to Mr. Olney, happily still living, to enforce their earlier counsels of perfection; to accept their work as an inspiration. For without the efforts of these men we should not be where we are to-day. They still speak to us by the mouths of the President and of his English colleagues in their great mission of peace and in their efforts for the peaceful settlement of disputes between the two great nations they represent.

The Arbitration treaty was a crisis in Lord Pauncefote's life as Ambassador. The second crisis was of a 
very different order, provoked by his rivals, of whom three were conspicuous agents in its first stage. They fashioned the material. They sent it to their governments, and one at least of those governments stored it away for future use; a deposit of dynamite. And at the moment when it was thought most likely to destroy Lord Pauncefote's influence and to make trouble between England and the United States, a great Potentate touched it off ; an Emperor-journalist, with a journalist's love of the sensational; the Hearst of Berlin.

For to disturb the friendship between Great Britain and the United States was then, and has since been, and still is, one cardinal point of the Kaiser's policy. His Imperial Majesty may suppose that his successive and continuing attempts to this end are not understood in America. But they are understood. Ask any American naval officer against whom or what America is building battleships, and listen to his answer. If you asked Mr. Roosevelt his answer might be, for reasons of State, less categorical yet still illuminating.

The story I shall tell is not new, for it goes back in its beginning to 1898 , and in its climax to 1902 , yet the facts are not, I imagine, fresh in the public memory, nor so well known in England and America as abroad, and I retell it briefly.

It is no secret that when we went to war with Spain in 1898 the sympathies of Continental Europe were on the side of Spain and not of the United States. It is no secret that some of the skilled diplomatists who represented those powers in Washington conceived a scheme whereby effect might be given to those sympathies. The leading mind among them-whether the leading spirit I cannot say, though I am inclined to think not-was the French Ambassador, M. Jules 
Cambon, brother to M. Paul Cambon, French Ambassador to Great Britain then and now. Among them, at any rate, they agreed that each should send to his own Government a proposal for a remonstrance to be addressed by all their Governments to the United States against the war. They were five in all. The five met by themselves and agreed to ask the British Ambassador to join them; and not only to join them but to draft the dispatch he and the five were to send to their Governments separately.

It was a very subtle piece of diplomacy. They did not disclose to Lord Pauncefote their real object. They knew him as a lover of peace and they thought it possible to induce him, as a lover of peace, to make an appeal to the American Government in the name of peace. This appeal they meant to turn to their own ends. They well knew that Lord Pauncefote would wittingly be party to no plot hostile to us. But they thought he could be used without his knowledge.

Had Lord Pauncefote been one of the diplomatic brotherhood, trained all his life in the arts of Continental diplomacy, no such scheme would have been hatched, still less proposed to him. But he was a man who used, as Burke used, " no arts but manly arts"; nor was it in his nature to suspect others of conduct less loyal than his own. Assuming that his colleagues came to him in good faith, in good faith he drafted the dispatch they sought from him. It was upon their initiative and request that he put upon paper his thoughts on the situation and his suggestions for a friendly proposal to the United States in the interests both of the United States and of peace. There was not a word at which an American could take offence. But this did not suit the purpose of the Five who 
on that eventful morning walked across Connecticut Avenue in a body from the Austrian to the British embassy. When Lord Pauncefote had read his paper a silence fell upon the company. Then one after another criticized and proposed alterations. Finally, M. Cambon offered to take it and redraft it in accordance with the general opinion of the Five. He did take it; left the library where they were assembled, went into the chancery of the embassy, was gone half an hour, and returned with the new draft which he read aloud. He had done his work with consummate craft; a craft equal in its way to Bismarck's with the Ems dispatch. With the exception of a single phrase, the paper was still, so far as words went, void of offence to the general mind. But to the diplomatic mind the new draft now read not as an appeal but a remonstrance, and a remonstrance such as no government addresses to another unless prepared to follow it up in one way or another. But the object of it was cunningly concealed in plausible phrases, and the transformation, unhappily, was not at once evident to Lord Pauncefote, and the offensive phrase passed equally unperceived.

There was a further discussion; the sitting lasted long; some verbal amendments were made, of no significance, and in the end the British Ambassador accepted and signed and sent to the Foreign Office in London, as his own, M. Cambon's dispatch. But the Foreign Office, with Lord Sanderson then its permanent head and always with a staff of men versed in the rules of diplomacy, said latet anguis in berba, and coldly made answer that Her Majesty's Government did not think it desirable to forward the dispatch to the American Government. And there, for the time, the matter dropped. 'The conspiracy had failed. 


\section{82 ANGLO-AMERICAN MEMORIES}

Four years later Washington was startled by a Press dispatch from Berlin, obviously official or semi-official, accusing Lord Pauncefote of having initiated and sought to carry through a measure of European intervention unfriendly to the United States and in aid of Spain. This charge, we were told, rested upon the contemporary dispatches of the German Ambassador, Baron Holleben, who had made a full statement of the facts to his Government. But the German Emperor, out of his infinite kindness and good will to America, had himself intervened to frustrate that wicked British plot. He had expressed upon the margin of the proposed remonstrance his Imperial disapproval and his Imperial command that no such remonstrance should be sent. The dullest could not but infer that Germany and not England was the true friend of the United States.

Why Germany had waited four years to declare its friendship, and why the declaration was made at a critical moment in the relations of the three Powers, the Emperor omitted to explain. But a high personage in Washington said :

"I do not believe the Imperial ink on the margin of Holleben's four-year-old dispatch was dry when the press telegram was sent from Berlin."

\section{III}

This blast from the Imperial trumpet at Berlin rang through the land. It was a declaration of the utmost gravity, and had to be met at once if the mischief it meant were to be prevented. I went to Lord Pauncefote early that morning and found him in no little anxiety. He said at once : 
"I know why you have come but I can tell you nothing."

I asked Lord Pauncefote to consider the nature of the accusation against him; the source of it; the world-wide publicity given to it; and the effect of it, both here and at home, on his position as Ambassador.

"Yes, I have thought of all that, but it is not consistent with my position as Ambassador to be drawn into a personal controversy. I shall make no reply. Better that I should suffer than that the interests of my Government and the friendship of the two countries should suffer."

Then I saw what I ought to have understood at first, that Lord Pauncefote not only put aside his own welfare and reputation, but that his refusal to explain sprang from his belief that any explanation, since it must be controversial, would be to the detriment of the great public interests he had at heart. You could read it in his face; care-laden, anxious, distressed. He looked older than yesterday; bent, half-broken. The shot fired from Berlin had reached him; he was a stricken man. In his thought for his country he was doing injustice to himself. I saw it was useless to talk to him of the wrong and outrage he was asked to endure. There was but one appeal to make, and I made it :

"Lord Pauncefote, I will do as you are doing. I will leave you and your character and honour-for both are assailed-out of the question. What I ask you is from regard to your Government, which is assailed through you, and from regard to the two peoples whom you have done so much to bring together, to let the truth be known."

He thought, and presently said :

"No, I do not see it as you do, and I can say nothing 


\section{84 ANGLO-AMERICAN MEMORIES}

to you as Times correspondent. But you are my friend and I will tell you the facts in confidence."

So he began the story given in my last chapter, of which I knew already the substance. But as he went on I saw that if all this was in confidence I could no longer use as they ought to be used the facts I had learned at the time from other sources, and I interrupted his narrative :

"Lord Pauncefote, this is far too serious to be handled as a private matter between you and me. I can listen to no more in confidence. Either our talk must end here or you must leave it to my discretion to deal with the whole as I think right."

Again he hesitated and I rose to go, but finally he said :

"Well, you may be a better judge than I of the public interests at stake. If you will consider those alone you may publish so much as you judge needful."

Then he went over the whole business. What I have said was based partly on Lord Pauncefote's statement, partly on other testimony. What I am concerned to make clear now is the absolute loyalty and disinterestedness of the Ambassador at whom these calumnies had been flung. When he had finished I asked a few questions, which he answered. Then I said :

"It is quite understood I am to use all this as I think proper. I only wish to say that I hope it may be possible to state all the essential facts in $\mathcal{T}$ be $\mathcal{T}$ imes without explaining that any of them came from you."

On that we parted and I went to the President. His first words were the same as Lord Pauncefote's :

"I know why you have come."

But he went on in a very different tone:

"I can answer your question before it is asked. 
Not only do I not believe this Berlin story, but I know it is false. I know Lord Pauncefote to be incapable of an act unfriendly to this country. Since he has been Ambassador he has striven with all his heart to promote good will between England and us. If he had said and done what Holleben accuses him of, it would have been disloyal to himself and treacherous to us. $\mathrm{He}$ is incapable of that. He is incapable of anything but true and honourable conduct."

"May I say in $T$ be Times that you said that ?"

The President's answer was characteristic.

"You may say that I said it, but not to you."

I obeyed at the time. But Mr. Roosevelt is no longer President and I am no longer Times correspondent; it is a case of cessante ratione, cessat lex. We shall never again stand to each other in the relation in which we then stood. The reason for his caution was evident. As it no longer exists, I hope he will hold me absolved from a promise which I kept as he meant it to be kept; while there was any necessity for keeping it. The jealousies of those days are, I trust, extinct.

I cabled the full story to $T$ he $\mathcal{T}_{\text {imes }}$ in which it appeared next morning. It was a statement which, on the face of it, was based upon knowledge and upon producible evidence. That, and its appearance in The Times, killed the Berlin fiction dead. There was a sort of half-apologetic telegram from Berlin on the day following, but that particular attempt to make a scapegoat of Lord Pauncefote and to embroil England and the United States was abandoned. I think I never did a more useful piece of work. The Emperor showed his chagrin by recalling his own Ambassador. Holleben deserved what he got, but he was not the one most to blame. 


\section{I86 ANGLO-AMERICAN MEMORIES}

During the few months of life which remained to him, Lord Pauncefote was failing fast but did his work as before. The attachment to him in Washington was such as no other Ambassador had ever called forth. For years the British Embassy had never been spoken of as the British Embassy. It was always "The Embassy." Holleben was furious at the distinction, and perhaps other Ambassadors, the Russian most of all, were vexed. But Washington cared naught for their anger, and when Count Cassini, having been recalled from Washington and sent to Madrid, thought fit to say he had been "promoted " to Madrid, Washington was only amused. The supremacy of "The Embassy" as a diplomatic and social centre remained untouched. Lord Pauncefote was the doyen of the diplomatic corps; thanks partly to the pains taken by Lord Rosebery, Foreign Minister at the time, that his credentials as Ambassador should reach him before any of his colleagues could present theirs. He was the first Ambassador who ever had audience of a President of the United States. It was well that this primacy should have been his; and well that the position had Lord Pauncefote to maintain it. The social atmosphere of the Embassy was always delightful; a condition due not to the Ambassador only, whose wife and family had a charm and popularity of their own. There has not been since, and it is not likely there will ever be, another Lord Pauncefote. It is still less likely that another Ambassador will have the opportunity of equalling his services to both nations, since all the great controversies then open are now closed. And Arbitration lights up the horizon.

The honours paid him on his death were without example. The President, who calls on nobody, flung etiquette to the winds and called in person on Lady 
Pauncefote to offer his condolences and his tribute to the dead. The President personally gave orders that the flags on every public building in Washington should be half-masted. He personally ordered the State funeral, an act which impressed England and all Europe beyond all others, except perhaps when, a little later, an American battleship, again by the President's orders, bore the body of this British Ambassador home to Great Britain. The President, again in disregard of a hitherto unbroken rule of etiquette, was himself present at the funeral service in St. John's Church. The orders to his Secretary of War for the parade of fifteen hundred American troops in honour of this British subject were the President's orders. The fifteen hundred lined Connecticut avenue from the Embassy to the Church.

All Washington was in mourning: in mourning for a great Ambassador and for a friend. The streets were thronged; the people in black. If he had been an American no deeper reverence could have been paid him, nor would the grief have been more genuine. 'The solemn service in the church ended, as if for a soldier, with bugle notes; "taps"; the camp summons to sleep; now to a lasting sleep. When the coffin was borne out, the President, his ministers and other great officers of state, judges, generals, admirals, and the foremost citizens of the capital, waited with heads uncovered. The troops stood to arms, then swung into column and moved on as the Ambassador's escort on his journey. And so, to martial music and the tread of armed men, the homage of War to Peace, this great messenger and instrument of peace departed from among us. 


\section{CHAPTER XVII}

THE PRESENT AMERICAN AMBASSADOR, MR. WHITELAW REID

R. WHITELAW REID has now been seven
years American Ambassador in London; a tenure long enough to create a pleasing impression of solidity in our diplomatic service. The impression, unhappily, is an illusion. Mr. Reid's length of service is due, not to any rule or custom of the State Department in Washington, but to personal qualities and special circumstances and previous cxperience. $\mathrm{He}$ had been a successful Minister to France from 1889 to 1892. Before that he had twice declined the mission to Germany. He was Special Ambassador at the second Jubilee of Queen Victoria in 1897, and again at the Coronation of King Edward in 1902. He had been the leading member of the Peace Commission of 1898 at Paris which framed the Treaty of Peace with Spain and, under his inspiration, induced President McKinley to agree to the acquisition of the Philippines. When he came to London as Ambassador of the United States, Mr. Roosevelt was President, and it was Mr. Roosevelt's habit to speak, as a Sovereign might speak, of " my" Ambassadors. But when Mr. Roosevelt ceased to be President in 1909, Mr. Reid remained Ambassador under President Taft and Ambassador he still is in IgI2, not of Mr. Roosevelt or Mr. Taft, but of the United States of America. 
As the United States Government have not yet thought it worth while to provide their Ambassadors with Embassies, Mr. Reid took Dorchester House, and there he and Mrs. Reid have ever since lived and entertained with a splendour for which there is no precedent. I refer to it for the sake of pointing out one result of Jeffersonian simplicity and economy in the pay of great public servants. The result of this penurious policy, long out of date, is that only rich men can afford to accept the higher diplomatic posts, and to maintain them as in Europe they ought to be maintained. Nor is the present Ambassador the only proof. His two immediate predecessors, Mr. Choate and Mr. Hay, serve also as illustrations. In all three cases the Embassy has been supported with dignity by private fortunes.

Mr. Reid's history before he came to London had as many sides to it as that of most successful Americans; perhaps more. Born in Xenia, a little town of the State of Ohio, seventy-four years ago, he graduated at the Miami University in 1856 , and straightway began active life as a journalist; plunging almost at once into politics as a legislator. Then came the Civil War and brilliant service as war correspondent and as aide-de-camp to General Thomas and General Rosecrans; then journalism in Washington, followed by a costly experiment as cotton-planter in Louisiana. But the decisive step of his life was taken in 1868 when Mr. Horace Greeley, then the greatest editorial force in the United States, asked him to enter the New York Tribune office. He became managing editor in 1869 , editor and chief propietor from 1872 to 1905 . It was a crisis in the history of that paper, and a crisis which might have proved fatal but for the business gifts and courage of Mr. Reid, who reorganized the 


\section{I90 ANGLO-AMERICAN MEMORIES}

concern and brought it prosperity by salutary methods which shareholders in want of dividends during these lean years thought drastic, as they were. He had a resourceful mind which shrank from no experiment. The Tribune building was the first of the structures which took a leap skyward : parent of the hundreds of "sky-scrapers" now to be seen in New York. He was the first to put to a practical and lucrative use the linotype and other machines for cheapening and expediting printing. He rearranged the editorial scheme of the Tribune, and it was in his reign that the great successes in 1870 and $187 \mathbf{I}$, during the FrancoGerman war, were achieved.

One other crisis in Mr. Reid's life, a crisis fruitful of good fortune, was his marriage in I88I to Elizabeth, only daughter of the late Mr. D. O. Mills, known to all Americans as a man who had won a great name and amassed great riches by wise and gentle means. The paths strewn with ruined rivals were never his. This auspicious union proved, among other things, that even marriage with a sound financial basis on both sides may be made in Heaven. London knows Mrs. Reid as a hostess with a rare gift of organizing the social successes which are almost a condition of an all-embracing diplomacy. Her friends know her as a woman with gifts still more rare; with endowments of patient sagacity and of skill in the conduct of life; with an influence the more potent because never ostentatious; with an organizing power of which her hospitalities and her far-reaching charities are alike examples; with a trained judgment in great affairs; with the final charm of simplicity and generous devotion to others.

In the midst of all his activities in journalism and politics, Mr. Reid wrote books and delivered addresses 
and, first as member of the Board of Regents of New York State, then as Vice-Chancellor, and finally as Chancellor, became an authority in Education. Diplomatic offers and honours followed : his place in public life broadened, and in 1892 he was the Republican candidate for Vice-President of the United States, marching to defeat in company with President Harrison. I omit details which would find place in a biography. My concern here is to mention only such matters as influenced not only a career but an individuality; things that went to the forming of the character which has impressed itself on the attention of the English. But, as perhaps the best illustration of all, I must find room for the story of his Philippine experiences.

The true story, or the whole story, of the acquisition of the Philippines was not told at the time. Whether it has bcen published since, I cannot say. What I knew in 1898 of the inner facts I knew in confidence and could not then relate, but there is now no reason why the essential part of the narrative should not be given : even though another leaf of the laurel which crowned Mr. McKinley's brow has to be plucked away. He was then President, and as the Philippines became American while he was President the annexation will always, I suppose, be reckoned his work. In fact, he never made up his mind about it. His mind was made up for him and the Peace Commissioners to whom he was supposed to give instructions ended by sending instructions to him. Not, of course, in the form of instructions. In form they were advising opinions, but they were put in such a way that the President had no choice but to accept them and act on them. If the attitude seems a strange one for the President of the United 
States, it is no stranger than his attitude throughout the Spanish troubles. In that war, or in the causes that brought on the war, his was never the initiative. After hostilities had ceased he still left to others the initiative of peace and the terms on which peace was to be made.

It was, of course, the President who appointed the Peace Commissioners, five in number. They were Judge Day of Ohio, then Secretary of State, Chairman; Senator Frye of Maine, Senator Davis of Minnesota, Senator Gray of Delaware, and Mr. Reid. There was both in the Commission and in the country a party for and a party against the taking of the islands. Mr. Reid's views were known to the President. He had published an article in the Century magazine of New York. The Commissioners held their first meeting in Washington, in the Cabinet room of the White House, ostensibly to receive their instructions from the President who was at the meeting. But in fact the President was not then (nor ever) ready to give his instructions. He desired to hear the opinions of his Commissioners and, having heard them and finding them divided, dispatched the Commission to Paris, without instructions.

Upon their arrival in Paris they were still divided. Judge Day, a man of singularly cautious temperament, wanted neither the Philippines as a whole nor any part of them, except possibly a coaling station and even as to that he was in doubt. Senator Gray was still more strongly opposed to the policy of annexation. Senator Davis, who had in him something of the knight-errant and therefore a touch of chivalry which might be called quixotic, declared himself in favour of retaining the northern part of the Archipelago, but was prepared, in his chivalrous way, to make a present 
of Mindanao and the whole southern part to Holland. As I understood, it was to be a gift, not a sale, and Holland was not to be asked to "pay anything" or to give anything in exchange. But if that could not be managed he was willing to make a bargain with some other European Power, receiving in return territory likely to be of more use to us. Senator Frye was, at first, inclined to agree with Senator Davis. Maine being one of the six New England States, and throughout New England opposition to annexation in any form having begun and seeming likely to grow, Senator Frye was for the moment, like a good politician, disposed to listen to the voice of the people who were his people.

Mr. Reid, who spoke last, had no doubts. He was for annexation pure and simple; for annexing the whole of the Philippines and not part. He took the view which I think an English diplomatist accustomed, as we were not, to dealing with problems of this kind would have taken. He held that the United States, having broken the Power which ruled the Philippines, had come under an obligation to take over the duties and responsibilities of that Power in these islands. We could not honourably, he thought, renounce these obligations, nor could we hand them over to another Power.

A strong man who knows his own mind is apt to be master of other men's minds, and so it happened in this case. Mr. Reid's was the only clear policy announced, except the policy of doing nothing and leaving the Philippines to become the prey of the Power that most wanted them; presumably Japan. The Spaniards, meantime, had shown their hands; reports of the negotiations had been sent to the President, and at last he called for detailed statements by in- 
dividual members of the Commission. Senator Day and Senator Gray read written declarations in favour of surrender. Mr. Reid read his, in favour of keeping the islands. A discussion followed, at the end of which Senator Davis and Senator Frye suggested to Mr. Reid that his statement might, without altering any essential doctrine, be put in such shape that they could sign it. This was done. Signed by Davis, Frye, and Reid, in the order named, it went to the President, in company with the opposing opinions of Day and Gray. Mr. McKinley's was a mind open to impressions, prone to accept the views of a majority, and grateful to those who would relieve him from the irksome duty of coming to a decision of his own. He acceptedMr. Reid's policy; and so Mr. Reid's conception of public duty, which had gone to the President as an expression of opinion by the majority of the Commissioners, returned to them in the form of instructions by the President, and the Philippines were annexed. The agreement to pay Spain $\$ 20,000,000(£ 4,000,000)$ as compensation for public works and property on the islands was in the nature of a solatium, and in no sense was it purchase money. The islands were ours, had we so chosen, without payment of a dollar.

I am writing of a man who for a quarter of a century was my chief; the editor of a newspaper which I served abroad. We were friends before that, and since, and I have had every means of knowing what he was like. I look back over that long period with a vivid sense of what I owe to Mr. Reid. Subject, of course, to his authority, I was given a free hand in European affairs. He took large and generous views both in the editorship and management of $\mathcal{T}$ be $\mathcal{T}_{\text {ribune }}$ and in his relations with his staff. I will restate what I said in the first series of these Memories of the way 
in which he handled one matter, which seems to have been misunderstood.

Like most American journals $\mathcal{T}_{\text {be }} \mathcal{T}_{\text {ribune was in }}$ favour of Mr. Gladstone's first scheme of Home Rule for Ireland in I886. I was not, and I was allowed day by day and week by week, by cable and by post, to say what I thought on that subject. I doubt whether at that time in any other important journal in the United States the case against Home Rule and the Home Rulers was freely and fully stated. It was a subject which then interested Americans profoundly. There, as here in England, the Irish Nationalists were masters of the art of adroit misrepresentation. The majority of the American Press and people were misled. They were asked to believe, and did believe, that the Home Rule which Ireland demanded would, if granted, have left her in a relation to the Government of Great Britain analogous to the relation between the States of the American Union and the Union itself. There was, of course, never a moment, and is not now, when the Irish Nationalists would have accepted that, but they induced the American people to believe they would have accepted it ; and the delusion captivated American sympathies.

On that and on the general issue I was allowed to present the views of the English who did not wish to see the United Kingdom broken in pieces; all the time in opposition to the editorial view of the paper in which my letters and dispatches appeared. The Tribune was criticized for allowing it, and I was criticized for presuming to have an opinion other than the gencral Amcrican opinion on that issue. I do not know that $\mathcal{T}$ be $\mathcal{T}$ ribune or I was ever a penny the worse for these attacks. But to Mr. Reid is due an acknowledgment of the wise liberality he showed; perhaps 


\section{I96 ANGLO-AMERICAN MEMORIES}

the wiser and certainly the more liberal because of his sensitiveness to criticism which he could well afford to neglect. Mr. Gladstone was aware of the facts. He knew that only by $\mathcal{T}$ be $\mathcal{T}$ ribune was the American support of his policy imperilled or diminished. It mattered little who held the pen. What mattered was the publicity in $T$ be $T$ ribune, but I was never forgiven by Mr. Gladstone for my share in the work. Against Mr. Reid he seemed to bear no grudge. They met on friendly terms. Mr. Gladstone was not likely to know much about the division of responsibilities in journalism. Whether he did or not he made no secret of his liking for Mr. Reid, in whom he thought he recognized a type of American not familiar to him; yet essentially American in character and in the wide range of his capacities and career.

I need not attempt a summary of Mr. Reid's work as Ambassador in England. It ranges from the Newfoundland Fisheries, finally referred to the Hague on his proposal, to opium conferences, Chinese proposals of many sorts, the Liberian loan, the Central American troubles, South American troubles, and many others which might seem to have no direct relation to this Embassy but are habitually referred to it, as the centre of American diplomatic activities abroad. But Mr. Reid's one great service beyond all others, and more important than all others, has been his steadfast and heartfelt advocacy of Anglo-American friendship as a policy alike beneficial and indispensable to both Powers. That point needs no arguing. It has become an axiom of diplomacy, and the work is carried on with equal zeal in London and in Washington. Mr. Reid has broadened the old diplomatic methods. $\mathrm{He}$ is Ambassador to the British people as well as to the British Government, and to the British people has addressed 
himself on topics likely to appeal to them and to elucidate American interests. He has spoken all over the kingdom to sympathetic audiences, on the great men of both countries; on Burke, on Lincoln, on America herself; and last of all, at the yearly reopening of the Philosophical Institute in Edinburgh, where he set forth with a wealth of new detail the indebtedness of America to Scotland and Scotsmen.

For this kind of work his lifelong love of books and of letters had trained him. Books he has always loved. When Minister to France he collected French books which, with still more ample stores of English and American, may be seen in the fine libraries at his New York house in Madison Avenue and his country house in Westchester. At Dorchester House and at Wrest Park he is still surrounded by books. With them he has made friends as with the people among whom he lives. Ambassadors come and go, but London and that larger London which is England will long remember the long intimacy which has grown up between Mr. and Mrs. Reid and the kin among whom they have lived.

One compliment, a diplomatic but involuntary compliment, he pays, Scot though he be by descent, to the country of his diplomatic adoption. He resembles nothing so much as a portrait of himself by Van Dyck, and nowhere is the likeness so striking as in Dorchester House, where other Van Dycks look down from the walls on their American cousin. 


\section{CHAPTER XVIII}

TWO METHODS OF DIPLOMACY, AMERICAN AND EUROPEAN *

I'T seems to be believed in America that our diplo1 matic service in Europe has been, on the whole, adequate and even distinguished. I do not think that is quite so. We judge by exceptions. We do not take account of the whole matter. We say, quite naturally: "We have had very able ministers; the business of the country, when it became critical, has been well done; the men we have sent to do it have been the intellectual equals of those whom they have had to encounter, and the records of the State Department in Washington are records of victories achieved or of honourable and useful compromises."

Even were that so generally, as it is undoubtedly so in part, it would not prove the case of those who argue that our haphazard methods have brought as good results as might have been obtained by a system and a service, neither of which have we ever had. For what we have to consider is, at least in part, the general impression produced on Europe by our Ministers and our diplomatic procedure. That is what a country is judged by in the long run, and not by the brilliant exceptions.

If we compare ourselves with any European country we may see, if we choose to see, what these old countries gain by their old methods. Suppose we take * Not published in The Tribune. 
England; not perhaps the instance which proves most, but the most familiar. She has, in the first place, a Foreign Office completely equipped; a permanent official at the head of its permanent staff; never appointed nor ever removed for reasons of party. It is a branch of the Civil Service. She has, in the second place, another body of Civil Servants who are Ambassadors, Ministers Plenipotentiary, Ministers Resident, Councillors, Secretaries, and Attachés. She pays her Ambassadors, in round numbers, from $£ 6000$ to $f_{1} \mathrm{i} 0,000$ a year, and provides each of them with a palace in which to live and do the business he is sent to do. She neither appoints nor dismisses them for political reasons. They enter the service as boys by a competitive examination. They rise, to some extent, by seniority, but for the highest posts seniority is tempered by selection.

If, as has sometimes happened, especially of late years, other men are needed than those available within the strict line of diplomatic promotion, they are taken from the outside, but have been, all save one, men of diplomatic training and experience. Lord Pauncefote went from the Foreign Office itself, of which he was Permanent Under-Secretary, to Washington. Although in the Foreign Office, and because he was in the Foreign Office, he was not in the line of promotion for abroad. Sir Michael Herbert, already Minister Resident at Paris, was made Ambassador to Washington over the heads of many seniors. Both rendered inestimable services to both countrics. Lord Dufferin, at Paris; Sir Henry Drummond Wolff, at Madrid ; Lord Curric, at Rome; Sir Charles Hardinge, at St. Petersburg; and Sir Francis Bertie, the present Ambassador in Paris, are all illustrations, and for the most part very brilliant illustrations, of this 
freedom of choice. The present British Ambassador in Washington is another illustration; which may also be considered brilliant from a business point of view. The Foreign Minister, who makes these outside experiments, is accustomed to choose as Ambassador one who is both a diplomatist and a man of the world. It is unusual to choose one who is neither.

My point is, however, that this system, which in theory is rigid, is in practice flexible, and accommodates itself to the necessities of cases as they arise. This elasticity in no respect impairs the advantages arising from a settled order. The advantages of permanence and of continuity remain, because permanence and continuity are the rule, and outside appointments are the exception, and have never been the rewards of party service, save in this latest instance in Washington.

Whereas with us, permanence and continuity, if they can be said ever to have existed, are the exception. Till quite recently they did not exist at all. The rule was instability, and I am afraid instability is still the rule. A recent case will show how lightly we handle such matters and, incidentally, to what financial straits our diplomacy is reduced. Mr. John Ridgely Carter, long known as Secretary of Embassy in London, was "promoted" to be Minister to Roumania. He was then offered, as a further promotion, the Argentine Mission, which he declined on the ground that he could not afford to accept it. The salary of the American Minister to the Argentine is $\$ 12,000$, or $\$ 2400$ a year; and the rent of a suitable Legation in Buenos Aires is $\$ 15,000$ or $£ 3000$ a year. The State Department is now able to supplement diplomatic salaries from a contingent fund, but the sum allotted in this case was far from sufficient, and so Mr. Carter's services are lost to the Government. He deserved a 
better appointment and a better fate, but Mr. Knox, who rules over the American Foreign Office, treated Mr. Carter's refusal as a resignation. Mr. Knox is a very able lawyer whose knowledge of diplomacy is a recent acquisition. He has shown in this and other matters a rigidity of mind which in the conduct of international affairs does not make for efficiency. It is a subject on which one is tempted to be indiscreet, but I pass on. In the London Embassy, at any rate, Mr. Knox has shown a sense of the fitness of things which may go far to excuse mistakes elsewhere. Indeed it would not be easy for a Secretary of State, unfamiliar though he may be with European usages, to undervalue Mr. Reid's services.

The first American Secretary of State to perceive the inestimable value of continuous service was $\mathrm{Mr}$. Hay. He had lived much abroad; privately and officially. He knew Europe well. He knew that England and France and Germany profited by their ordered and continuing diplomacy. He knew the prestige of their Foreign Offices; organized solely in order to conduct Foreign Affairs on business principles. He knew what weight of authority attached to the great embassies because, without exception, British and French and German Ambassadors represented not this or that party at home but the State. He would admit, as we all do, that individual American Ambassadors have put behind them party predilections, and that their voice has been the voice of America. But how was the foreigner to know that, when he well knew that they were appointed first of all as Republicans or Democrats and not as Americans? No British Ambassador was ever regarded as Conservative or Liberal. Probably he had no politics. Certainly as Ambassador he had no politics. He was 


\section{2 \\ ANGLO-AMERICAN MEMORIES}

an Englishman, first, last, and all the time. Let us reflect for one moment on what that means.

Mr. Hay had seen this system at work all over Europe. He had studied it in its relation to different Powers. When President McKinley made him Secretary of State he set himself to imitate it. If the word imitate excites a prejudice, I will phrase it differently. He set himself to appropriate, so far as he could, what there was best in it, and to adapt it to American uses. He promoted Mr. Lloyd Griscom to be Minister, and from Minister to Persia and Japan he became Ambassador to Rome, with the best results. Mr. Root, I must say in passing, took up Mr. Hay's idea and acted upon it with, in most cases, sagacity and discrimination. I think it a misfortune for the public service that $\mathrm{Mr}$. Griscom should have ceased to be Ambassador at Rome, though whether he resigned for private reasons or in obedience to custom I know not. It is a misfortune, although he had a competent successor. Mr. Meyer was sent from Rome after five years' service to St. Petersburg, where he remained two years ; in each capital a capable representative. Mr. McCormick was an instance of the blending of the two rules, the rule of service and the rule of politics. He was Minister to Austria-Hungary; Ambassador to Russia ; finally Ambassador to France. It looks on the face of it like a beautiful example of the new rule of promotion for good service. But Mr. McCormick's original nomination and his successive transfers were due to political influence of a kind that was thought irresistible. The result was not such as to justify the experiment.

The best instance of all is Mr. Hay's promotion of Mr. Henry White, after twelve years' distinguished service as Secretary in Vienna and in London, to be 
Ambassador in Rome, and from Rome to the Embassy in Paris upon the unregretted retirement of Mr. McCormick. In all these places Mr. White has been a diplomatist of marked ability. At times-as at Algeciras, where he found the formula which kept that troublesome Conference together and brought about agreement-he has shown himself equal to great emergencies. London, Rome, Paris, all agree in their high estimate of his capacity. Upon the expiration of Mr. Roosevelt's Presidency, the one diplomatic request he made of his successor was for the retention of Mr. White as Ambassador in Paris. Mr. Taft, for reasons which I do not understand and therefore do not criticize, disregarded Mr. Roosevelt's recommendation, and accepted the resignation which Mr. White, like every other American Ambassador, had offered as matter of form and in obedience to custom. Mr. White had made for himself not only a position in Paris but a European reputation. No reason was given for his removal. It passed as a Presidential caprice. To say that it was regretted is to say nothing. The official and social worlds of Paris were astounded. The American Embassy had been, while Mr. and Mrs. White were Ambassador and Ambassadress, a social head-quarters not for Americans only but for what there was best in French life. At the French Foreign Office Mr. White was regarded as, in every best sense, a representative of his country whose interests he knew how to defend, while never forgetting the ménagements which diplomacy expects of every diplomatist in high place. Experience, personal fitness, popularity -all these counted for nothing and Mr. White was dismissed. He has since been sent on an important special mission to South Amcrica. Such a mission, for which the President rightly thought Mr. White the 


\section{ANGLO-AMERICAN MEMORIES}

right man, requires far more tact and more diplomatic capacity than the Embassy to France. With France our relations are those of easy friendship, of which any disturbance is likely to be limited and momentary. With the South American States we are in relations which are always delicate and sometimes dangerous. Upon the kind of protectorate exercised by the United States in virtue of the Monroe doctrine, such Powers as the Argentine, Brazil, and Chili look with a vigilant scrutiny that may readily harden into suspicion. Their susceptibilities have to be considered. They need a gentle hand and sympathetic treatment throughout. If Mr. White were equal, as he certainly was, to a mission so difficult as this, what reason could there have been for removing him from the Embassy at Paris, where diplomacy goes sur des roulettes? I do not know that any answer has been given to this question. It need not be pressed, for the sending of Mr. White to South America is a confession that his recall from France was a mistake.

I should offer no criticism on President Taft or on Mr. Knox, except this : that they imperfectly comprehend the situation abroad with which they are called upon to deal. I will put it in this way. No political or party advantage at home could counterbalance the loss and injury abroad if Mr. Hay's and Mr. Root's rule and practice are to be disregarded, and the diplomatic nominations to be flung to the wolves again. The wolves are the politicians. Mr. Taft is skilled in politics, as we all know, but he is also President of the United States, as we all know, and his first obligations as President, and last, are to the United States and not to the Republican party. With a State Department still so imperfectly equipped as ours, lacking money, men, organization, and much else, the 
obligation to keep good men in their places abroad is the more imperative. The question for him and for Mr. Knox is whether they will carry on the good work begun by Mr. Hay, to whom President McKinley gave a free hand, or whether they will break in upon it and impair the diplomatic prestige Hay had begun to establish.

Lord Rosebery, in that speech to the Imperial Press Conference-which has gone echoing round the world to re-echoing applause, as perhaps no other speech in our time has gone-put the case for stability and permanence with his wonted felicity and force. He proposed, not quite seriously nor altogether in jest, a new use for "surplus" battleships. He would have Parliament vote supplies for two years " and then pack itself in three or four of these obsolete warships and go for a trip in order to find out something about the empire." He continued :

"You might object at once, in limine, to my scheme and say, 'How would the country be governed while all the Ministers were absent ?'

"I reply with confidence that it would be governed much as it is now, by the permanent heads of the departments, and I am sure that some of us would feel even greater confidence in the welfare of the country if it were under that permanent and wellordered control."

That, of course, includes the Foreign Office, and the Foreign Office includes diplomacy, and it cannot be too often repeated that continuity of foreign policy is one main secret of strength; and continuity in the diplomatic service one chief cause of efficiency. Lord Rosebery has been Foreign Minister, a great Foreign Minister, and knows as much about it as anybody. This is his testimony; the testimony of an cxpert. If 
you proposed to any European Power to adopt our happy-go-lucky practice you would be laughed at. In all of them the diplomatic service is, first of all, a service, to which men give their lives. We have no service. It is in all European countries a first line of defence. Before you can begin a war you have got to get past the diplomatists. They are entrenched in traditions, in fixed principles of international conduct, in fixed methods of giving effect to their principles. They have an understanding among themselves. They speak a language of their own. No matter whether it be English or German or French-it is usually French-they use words in an acquired, technical, diplomatic sense, perfectly familiar to them, unfamiliar to others. They have learned by long experience how to make use of social forces. They have studied not only national characteristics but personal characteristics. There are, in the German and other foreign offices, the dossiers of every Minister and Ambassador in all Europe. They have a code of morals all their own.

How is all this to be mastered by the able amateur whom we send abroad, once in four years, to measure himself with the professionals of every other Power? If he has a natural aptitude for such studies he will see the complexity of the problem, and he will set himself to solve it. With his American quickness and flexibility of mind he will, at the end of two or three or four years, have learned a good part of his new trade. Then he will be recalled and a new man be sent to go through a similar apprenticeship; and he also, about the time he has become fit for his work, will give way to another raw hand.

We have often been well served abroad; sometimes brilliantly well. In such cases the merit is never that 


\section{TWO METHODS OF DIPLOMACY 207}

of the system but of the individual. There is no system. If there be, it is the system of Monte Carlo. We gamble with the international fortunes of the Republic. We sometimes win, but the fact that a coup comes off now and then does not prove trente et quarante to be a wise policy for the conduct of great affairs. 


\section{CHAPTER XIX}

THE AMERICAN SPEAKER, MR. THOMAS B. REED

I MENTIONED Gambetta, but it would be pos1 sible to find a much closer analogue to Mr. Lowther in an American whose fame once covered a continent, and perhaps still does; I mean Mr. Reed, the " Tom " Reed of Washington and Maine politics. Mr. Reed, it is true, was far more tyrannical than it is possible for the Speaker of the Housc of Commons to be. You must make allowance for circumstances and for the radical differences in the nature of the two offices which bear the same name. Mr. Reed had a sense of humour, as Mr. Lowther has, and the American sometimes allowed his sense of humour to run away with him, which the Englishman never does. It never would have occurred to this or any other English Speaker to set up a mastery over legislation, or even over the business of the House, such as Mr. Reed established and his successor has perpetuated and even strengthened.

I once asked Mr. Hitt, the accomplished chairman of the House Committee on Foreign Affairs, how he managed to get his bills through the House. This was at the time when Mr. Reed had consolidated his great power as Speaker and had the House thoroughly in hand. Mr. Reed and Mr. Hitt were great friends, and I imagined this might make things easier for a chairman in Mr. Hitt's position. Whether it did or not you may judge from his answer : 
"Of course it requires a little diplomacy. So congested is the business of the House that to reach a bill in its numerical order on the calendar would take about fourteen years. But I will tell you what I do. I wait till some afternoon toward the close of business, shortly before six o'clock when few members are present, and I look about the House to see if any member is there who is likely to oppose the particular bill I think it important to pass. It is my business to know my opponents. If I see no one I rise and move that this bill be made a special order for a specified day some six weeks hence. If there is no objection, the Speaker declares the motion carried. Probably nobody present has any idea what the bill is. The effect of such a motion is that my bill on the appointed day has precedence and may be brought up whenever I think best. Again I consider the state of the House. It would be too much to expect the bill to pass unopposed in all cases, but at least it has a fair chance and a majority of our friends are pretty certain to be there, and so the bill goes through. The Speaker has such a control over business that a party measure, or a measure of which he and the leading members of the party approve, is fairly safe. I need not tell you that foreign affairs are not those in which the greater number of Representatives are the most interested."

I used to think Mr. Reed's physical bulk gave him, in a measure, or helped to give him, his mastery over the House. He was nearly as big as the President of to-day. When he rose he seemed to fill the desk and almost the hall itself. He towered above the three hundred and more Representatives; dominated the whole body; sometimes domineered over it. Who could dispute with such a mountain of humanity as that? From the slow movement of the huge body 
and the slowness of his speech the unwary were apt to think the mind also was slow. But he was one of those rather unusual men who speak slowly and think quickly; as his assailants from the floor soon found. Like Hamlet, he would speak daggers but use none. But his enemies went down before him.

A fault in most presiding officers in the legislatures, state or national, in America is the excessive use of the gavel. Mr. Reed had it, but in less degree. It is a vice which has grown. The last time I was in the House of Representatives Mr. Speaker Cannon pounded away as if he were breaking stones on the road. The din was incessant and quite useless. Members did not stop for the pounding. They stopped when they had made as much trouble as they thought sufficient for the purpose, or when they were tired. It is a turbulent body, no doubt. You see the Speaker erect and half a dozen or a dozen men on their feet at the same time. In the House of Commons when the Speaker rises every one else keeps his seat and is glued to it till the Speaker resumes his chair. His rising is a signal which no man disobeys. There are scenes of tumult, no doubt, at times, and the House becomes volcanic, but I am speaking of disorder as a habit. It is a habit in Washington, in the Senate as well as in the House, and it is not a habit at Westminster.

One often hears it said that the Senate is the most dignified legislative body in the world. I will not go to the other extreme and say it is one of the least, but it is certain that the European observer is not impressed by its deportment. There also, as in the House, may be seen half a dozen members all up together, competing for the attention of the President, and continuing to compete after he has made 
his choice. The noisy summonses to the pages and the racing of the pages to answer them add nothing to dignity. I suppose the President of the Senate, when he is Vice-President of the United States and therefore not a member of the Senate, has less authority than has an elected Speaker of the House, or an elected President of the Senate. But neither did Mr. Reed, the greatest of Speakers, enforce any system of unvarying good behaviour upon his unruly subjects. He did not set a very high value upon tenue, in or out of the House. You would see him, after the House had adjourned, rolling comfortably up Pennsylvania Avenue in a suit of clothes meant for country wear and a bowler hat. Mr. Hitt would be with him, arrayed in the same sort of costume. Mr. Hitt was of slight build. There is a well-known caricature in the Vanity Fair series of old days, with the late Mr. Corney Grain, a rotund giant of a man, smiling down on Mr. George Grossmith, who was anything but a giant. The contrast in this case was much the same.

Mr. Reed had perhaps the finest mind among politicians, or, if you like, statesmen, of his own day. If I wanted an original view I used to go to Mr. Reed for it, and got it, and sometimes even got leave to use it. When you went to him you found him in a dingy little room in the Shoreham, which he nearly filled. The space that was left was devoted to a writing desk, two chairs, and a tumbled mass of House bills and other official papers, apparently all in confusion. It was not a cell to which the Speaker should ever have been condemned. Everybody knew that Mr. Reed had no fortune and that as Speaker he was stingily paid, as all great officers of State are in America from the President down. I don't put it as a personal question, nor is the chicf fault of such a system the 
vexation to which it subjects distinguished servants of the State. It is the dignity of the State itself which is in question. It is the State which suffers when they suffer. They are representative, and the State, out of its $\$ 600,000,000$ of yearly revenue, could perhaps afford to pay them well enough to maintain in the eyes of the world the dignity of one of the greatest Powers in the world. But it does not.

I do not know that Mr. Reed cared. He was not the sort of man to whom money comes first. Disappointed ambition, a just ambition which it was the interest of the country to gratify, was the real burden on his life at the end. I suppose he could have had the Presidency if he would have made certain concessions. But he would make none which he deemed dishonourable, or inconsistent with principles which all men knew he held.

But I was saying that he had original views, and not views only, but conceptions of public life. He was the first man whom I ever heard point out the decay of Irish influence in America. It must have been about midway in the 9o's that he announced this discovery. He said :

"The Irish in the United States are on longer a political force. Time has been, as you well know, when the effort to secure the Irish vote was one of the chief anxieties of politicians on both sides. This anxiety showed itself in Congress, in the Press, in State Legislatures, in political contests all over the country. That day is past. You must have noticed the change in the Press. The Press is free again, and we here in Washington are free, and Americans and not Irish now govern this country. There are exceptions, but they are few. I do not think there are half a dozen districts throughout the land where the Irish 
vote now turns the scale, or where the bosses arrange their campaign with a view to capturing it."

I asked why there had been such a change. $\mathrm{He}$ answered :

"I cannot tell you why; or if I could it would be a long and complex statement. What is vital to us is not the reason but the fact, and you may take the fact from me.

"Yes, and if you like to tell your friends in England, do so. It may help to improve the relations between England and us, and it is for the interest of both countries that they should be improved; and they will be improved at no distant date."

It is not my business to offer any opinion on this declaration. But the fact that it was made, and made at least fifteen years ago, has a great significance. Since I 898, when England put her veto on the proposed European coalition in favour of Spain-a proof of good will which convinced the American people that England was their friend and not their enemy, as they had so long been taught to believe-it may seem less remarkable than it did at the time it was uttered. But as an illustration of Mr. Reed's political genius it is all the more remarkable because it was made so early. I do not know that he had many English sympathics. When he came to England, shortly before his death, he had planned to spend two months here. But he went home long before that short period had expired. He had come too late. He could not all at once open his mind to new interests or new impressions.

I end with an anecdote, of which the scene was Ellerslic, Governor Morton's delightful place on the Hudson, where you may form some notion of what an English park is like without crossing the Atlantic. 


\section{I4 ANGLO-AMERICAN MEMORIES}

Mr. Reed and Mr. Choate were two of the guests. We were in the thick of our troubles in the Philippines. Mr. Reed, as everybody knew, had opposed the acquisition of the islands. One night after dinner, the whole house party present, he and Mr. Choate debated the matter at length and with great freedom. Mr. Choate gave us in his forcible and forensic way-and no man could state a case better-the reasons for keeping the Philippines and reducing the "rebellious" Filipinos to order. We all listened. Nobody interrupted the flow of Mr. Choate's argument. Mr. Reed did not interrupt. At the end Mr. Choate, urging that surrender was impossible, asked triumphantly:

"What do you suppose the Filipinos would do if we withdrew the American troops?"

"Well," drawled Mr. Reed, "I don't suppose they would pursue us further than San Francisco."

And that discussion came to an end. 


\section{CHAPTER XX}

MR. JUNIUS S. MORGAN

I ONG before I knew Mr. Pierpont Morgan I knew his father, Mr. J. S. Morgan, a name then and now held in respect and admiration in the City of London-that is, in the English world of finance-as I hope and suppose it still is in New York. I remember him for many kindnesses, and many pleasant associations, and still more for a force and dignity of character rare at all times. He was a successful man in the City before he became a power there. The date of his becoming a power was I87I. Gambetta was at the head of the Government of National Defence at Bordeaux, and sorely in want of money. M. Laurier was his Minister of Finance and undertook to negotiate a loan for $f_{1} 10,000,000$. London would not look at it. One great house after another declined to find the money. It was not so much a question of price as of security. The English bankers and financiers had no confidence in the stability of this Government. They had not forgotten that Thiers had called Gambetta a fou furieux. They thought the future of France lay in the hands of Germany, and that Germany would restore the Emperor to his overturned throne; that the provisional Government at Bordeaux would be swept out of existence, and that with it would go all its works, financial and other. One and all they refused to put the Laurier loan on the market.

At this juncture Mr. J. S. Morgan, not at that time one of the great houses of finance, came for- 


\section{I6 ANGLO-AMERICAN MEMORIES}

ward and offered to take the whole loan. His offer was accepted. To the surprise of the Rothschilds, the Hambros, and the rest, Mr. Morgan's operation proved a success. The loan was floated. The public bought. The price went up. Mr. Morgan made a great deal of money and a reputation not to be measured in money. He stepped at one stride into the front rank.

All this I heard at the time or not long after from various good sources. But nobody seemed to know why he had done it, or whether it was anything but a gamble followed by good luck. One day I asked Mr. Morgan :

"Why did you take the Laurier loan ?"

He thought a moment before answering, then said : "Oh, there's no secret about it, nor was it altogether luck, as I believe some of my City friends thought. When it first occurred to me that something might be done, I looked up the financial history of France. I found that since 1789 there had been a dozen separate governments-Monarchy, First Republic, Directory, Consulate, Empire, the Bourbons again, then the Orleanists, then the Second Republic, followed by the Second (or third) Empire, and so on. Between these successive governments there were enmities of many kinds; dynastic, personal, political. Each successor, with one exception, hated its predecessor. It was one long civil war.

"But I found this also. Not one of these governments had ever repudiated or questioned the validity of any financial obligation contracted by any other. The continuing financial solidarity of France was unbroken. It was plainly a policy rooted in the minds of the people and of the governing forces of France. I saw no reason why it should be broken in this case 
more than in any other; less, perhaps, than in many others since this money was wanted for the defence of the country. That was good enough for me. There was no gamble. I thought it a safe operation as it turned out. That is the whole story."

Of course, Mr. Morgan knew it had been a great coup; knew what an authority it had given him in the City, and there was a fire in his eye as he spoke which showed he was not insensible to the triumph he had won. Why should he be? It was considered, and has ever since been considered, an event in the history of English finance. Now and then I have asked one of the big men in the City:

"Why did none of you except Morgan think of it ?"

Generally there was no answer except a regret, or a shrug of the shoulders, but one of them said :

"Because Morgan was a better man than any of us."

And to the day of his death he held the position he had won.

Where is the American who does not read such a narrative as that with pride? We have had many men who have done us honour abroad; none that I know of who did more for himself and his country than Mr. J. S. Morgan. He made a great fortune. He left a great name. The two do not always go together.

There are private memories which I cherish; and perhaps one or two which I need not keep to myself. Dover House at Roehampton, now Mr. Pierpont Morgan's, was not an important country place, but a suburban villa standing in pleasant grounds which in America, where land is scarce, would be thought spacious. But in this narrow island in the narrow seas nothing is thought spacious till you begin to reckon by thousands of acres. However, you don't expect thousands of acres in the near suburbs of 
London, and Dover House has as many as you need care for and be happy. Mr. Morgan's tastes were, in a sense, simple. He cared nothing for display. Beautiful things he loved, and Dover House was full of them. $\mathrm{He}$ had what he wanted. The atmosphere of the place was that of a home. There were gardens, and when you walked in them with Mr. Morgan at the right season he would take you to the strawberry beds and without fear of his gardener turn you loose in them, saying :

"If you can find finer strawberries anywhere perhaps you will tell me where they are."

They were magnificent. Then to the stables; not large, but whatever there was in them that stood on four legs showed the lover of horses and his knowledge of horses. "There's blood for you," was his only comment as he caressed the shoulders of his favourite bay. Then a pair of carriage horses, blacks :

"They will take me from the door of Dover House to the door of Prince's Gate in twenty-five minutes; and do, every morning."

The distance is seven miles, and the standard of trotting speed is very different in this country from the American standard. There were no motors, and men were still of Dr. Johnson's opinion that life had few better pleasures to offer than being whirled along in a post-chaise or a phaeton.

Inside the house there were pictures and tapestries and other works of art, but not too many. In a frame hanging on the wall in the drawing-room was a piece of Spanish embroidery, lustrous with old gold, I think of the sixteenth century, from some monastery, or more probably church, of Castile, a thing very lovely in itself which had a fascination for its owner. If you noticed, you would see his eyes turn often to 
this and to one or another picture. To him they were all friends. Dover House was not a museum, as Prince's Gate was then beginning to be and has long since become. Its treasures were not there for show, but because they were treasures and because Mr. Morgan, as I was saying, loved beautiful things.

Perhaps he was himself the most beautiful thing in Dover House. The grave, strong beauty of his head was remarkable, with the great sweep of the lines about the temples; the lined forehead, broad and high; the eyes full of light ; the face ending in an immovable jaw, all will ; the mouth none the less kindly and the lips smiling. When he gave you his hand you knew whether he thought you a friend or not. Distinction in every line and movement; a man used to giving orders and having them obeyed; taking decisions quickly and taking the right ones. He had fought the long fight and won it ; with a life behind him of accomplished purpose and unbending integrity.

I dined there often, sometimes alone, sometimes with company. Mr. Morgan was one of those hosts who knew how to take care of his guests without seeming to. He carried his simplicity of demeanour into every part of life. There was no effort, but things went on as he meant them to. As a rule, he talked of anything but business; topics never failed him, nor considered views. Once or twice I have seen him angry, and he showed his anger by a sudden restraint of speech and of manner. He had it in him to be, like the husband of Elizabeth in her German Garden, a Man of Wrath, but it was not allowed to appear in these circumstances. He liked to find out what his guests cared for and liked to surprise them, or perhaps to see whether they were capable of surprises. I said something one day at dinner about the champagne. 
"You think it good?"

"It's a wonderful wine."

" Do you know what it is ?"

"No."

"Perrier Jouet of 1865 ; and very nearly the last of it. I am no longer allowed to drink it, but there will be a bottle for you whenever you come."

Then he said he had once asked one of the great champagne merchants at Reims what he thought the best champagne ever known in the market: "Next after your own, of course." The great man answered :

"'There's no question of mine or of any other. We all agree that the finest wine ever produced in Champagne was the Perrier Jouet of 1865 . The best of the 74's don't touch it."

'To me, as to everybody, in great matters and in less, Mr. Morgan was as good as his word. The bottle of Perrier Jouet was always there. He himself drank only a tisane. If there were other guests it was the same. The butler used always to say to me as he filled my glass : "It is the wine Mr. Morgan ordered for you, sir."

The accident which caused his death as he was driving on the Riviera may be set down to whatever authority is responsible for the road-building in that part of the world. The causeway ended in a gutter on either side, cut sharply away from the road, not deep, but more than enough to upset a carriage. Mr. Morgan stood up in his victoria, the horses swerved, the wheels went over the edge, he was thrown out, and that was the end. He was, I think, seventy-three or seventy-four, but the fate which robbed him of the years rightfully remaining to him was none the less cruel; to him and to his friends. 


\section{CHAPTER XXI}

MR. PIERPONT MORGAN

I BEGIN with a financial anecdote, the date of which is long before I knew Mr. Pierpont Morgan. Like some others to follow, the origin of it is London; the City of London, where Mr. Morgan has been in times past regarded with more awe than affection. The Orientals, says Macaulay, or some of them, pay their sincerest homage to the deities whom they most dread; indeed, they are chosen as deities only in order to be propitiated. And perhaps in this case, though the East is East and the West is West, the East is West also. In any case, this is, I believe, the first transaction which brought Mr. Pierpont Morgan into notice in the City as, in one sense, a rival to his father, in whose lifetime the transaction was carricd out.

One of the foremost houses in London, or in Europe, had been applied to by the United States Government to arrange for the payment of a large amount of outstanding Five-Forties. The amount was $\$ 40,000,000$. The proposal was made in the spring, and our Government desired the operation to be completed and the whole sum remitted to the Treasury at a fixed date in the autumn; I suppose on the expiration of the first term of years when the Government had a right to redeem the bonds. I know the name of the London firm, but it is not necessary to mention it. The head of the firm at 


\section{2 \\ ANGLO-AMERICAN MEMORIES}

that time-he died long since-was a man of great capacity and authority, with an unrivalled knowledge of finance and an unrivalled experience in great financial enterprises. Naturally he was also a man of conservative temperament. He thought $\$ 40,000,000$ a very large sum of money to find all at once, and to find, or have ready, six months hence, when no one could foresee what might be the condition of the money market. If conditions were favourable, there would be a large profit on the transaction, but the profit might be turned into a loss should the Bank rate go up beyond a certain point. There were many other things to be taken into account and other people to be consulted. All this required time. Finally the firm proposed to our Government to take $\$ 20,000,000$, with the option of taking the other $\$ 20,000,000$ at a specified date.

The morning after this proposition had been sent, the firm received a dispatch from New York saying that Mr. Pierpont Morgan had offered to take the whole $\$ 40,000,000$ on the terms originally submitted to the London firm, and that the Government had accepted his offer.

It was a surprise, and something more than a surprise. Mr. Morgan was then a young man, a member of the firm of Dabney, Morgan \& Co.; almost unknown in London. There was no suggestion-there could be none-that either he or the Government had acted in bad faith or in disregard of any obligation to London. It was simply a case where American energy and courage, personified for the moment in Mr. Pierpont Morgan, had anticipated the slower movement of the English house. But it was resented; I should think bitterly resented at first, and even when reflection had shown that neither 
Mr. Morgan nor the Government could be blamed, some of the bitterness remained. A firm like this, with its great position and cautious methods, perhaps thought itself entitled to notice before a negotiation of that magnitude was broken off. At any rate, it had slipped away from them, and $\mathrm{Mr}$. Pierpont Morgan suddenly appeared on the Western horizon as a figure henceforth to be reckoned with. It cannot have been very long after his father, Mr. Junius S. Morgan, had electrified London by his boldness and success in the Laurier loan, as I explained the other day. In this American matter the father had, as I understand, no share. But there were now two Morgans instead of one, with only the Atlantic between them, and what is the Atlantic?

Years after, when Mr. Morgan began to launch one scheme after another on the London market, some of which failed, he was aware, I imagine, at times, of an opposition which neither the merits of his schemes nor the circumstance of the market explained fully. They would tell you in the City that American methods of finance were not altogether liked in London, that Mr. Morgan's methods were not liked, that the commissions paid tended to demoralize the market, and that it was as well Mr. Morgan should let the fact that London was not New York sink into his mind. Now and then somebody would add :

"There are perhaps powerful interests that intervene which are hostile to Mr. Morgan."

In short, it was said that the firm from whom Mr. Morgan had taken away the $\$ 40,000,000$ contract with the American Government had not forgotten it, and that they were not unwilling to put a spoke in his wheel, once in a while, as a reminder. But I have the best authority for saying this is not so. The fact 


\section{4 ANGLO-AMERICAN MEMORIES}

that it was believed in the City to be so shows, perhaps, or did show, a certain drift of opinion which ran counter to Mr. Morgan's wishes. The names of some of the companies or other enterprises which Mr. Morgan undertook to float and did not succeed in floating, or succeeded only in floating at the expense of those to whom shares were allotted, are as well known in New York as here.

Since I have begun with finance, about which I know nothing except what I am told, I will go on. One or two incidents made a deep impression on my innocent mind when $I$ heard them, and on other minds less innocent than mine. One relates to that period of distress in America when we were said to have been within twenty-four hours of paying our debts in silver ; in other words, of bankruptcy. Mr. Grover Cleveland was then President, whom one of his friends and advisers-not Mr. Morgan-once described to me as ignorant of finance and all fiscal matters, saying:

"All he ever knew I taught him, and to teach him was impossible. He would absorb the facts of a particular financial trouble and understand, or at least adopt, the remedies I suggested; and so he would pull through. But the next time a difficulty occurred he was just as helpless as before, and everything had to be gone over with him again. He could not grasp a principle. To the day of his death he understood neither money nor business."

In the crisis I refer to I believe a loan was wanted and gold was wanted; a loan, if I recollect rightly, of $\$ 200,000,000$; and $\$ 40,000,000$ of gold within a short period. Mr. Morgan was summoned to Washington, as so often happened. A conference took place between Mr. Cleveland, with some of his official advisers to help, and Mr. Morgan. Mr. Cleveland said : 
"Mr. Morgan, you all seem scared in New York and think we are in great difficulties here about money, but I don't see that things are so bad as all that. The Secretary tells me we have $\$ 7,000,000$ in the Treasury this morning."

Mr. Morgan answered :

"Yes, Mr. President, that is true, but I have in my pocket a draft on the Treasury for $\$ 12,000,000$, and $\$ 7,000,000$ won't pay it."

This concrete illustration presented things in a new light to Mr. Cleveland, and he gave his assent to the arrangements his official advisers were urging on him; which Mr. Morgan was then to carry out. The $\$ 40,000,000$ in gold was found within the agreed time and paid into the Treasury, and we did not go on a silver basis nor into bankruptcy. But when it became known in New York that Mr. Morgan had pledged himself to find these forty millions in gold, the great bankers, I am told, shook their heads and said it could not be done.

"Where is Morgan to get his $\$ 40,000,000$ in gold? It is not to be had in America, and if he brings it from abroad it will send exchange to a point which will cause disaster."

And yet it was found, and exchange hardly moved. I asked some of these great financial authorities how Mr. Morgan managed it. They all said much the same thing.

"You must ask Morgan. We do not know."

Perhaps the highest tribute that could be paid him, for it was equivalent to saying: " $\mathrm{Hc}$ is in a class by himself." In the end, from a banker of renown, I got a better answer :

"I do not know what Morgan did in this case, but I know Morgan, and I think it probable he had long 


\section{ANGLO-AMERICAN MEMORIES}

foreseen this demand for gold, and that when he was asked to supply the $\$ 40,000,000$ he had already accumulated the greater part of it, or arranged for its transfer as wanted from I know not what vaults."

The English thought that. One of them said a similar thing during the crisis of 1907 :

"Nobody looks so far ahead as Morgan. We are told here that for many months before the crash came he had been selling securities. When it came his bank balances made him master of the situation. We have had serious moments here in London, of which the Baring trouble was the most dangerous, but in that and other cases we have acted together. But we have never known anything like that day in New York, when money was 100 per cent and not to be had at that, when Morgan flung on the floor of the Stock Exchange $\$ 25,000,000$ at 10 per cent, and the danger was over."

He continued :

"What I say of Morgan is that he has shown himself again and again a man who can take command of a situation, and the greater the peril the more absolute is his control."

There floated over to London at a later date a different sort of story. It was, I think, during the last of the crises, when Mr. Morgan summoned the leading bank presidents and other magnates in finance and laid a plan before them, to which they all assented. But one considerable personage had stayed away from this meeting. When it was over Mr. Morgan sent for him, and he came. Said Mr. Morgan :

"Mr. X., you know what we have agreed on. You alone stand out. I think it important, in the interest of your bank and of all the banks, that you should come in."

"No," said Mr. X., "I shall not come in." 
"Then I give you fair notice that if you do not I will break you and your bank together."

And he came in.

Of course I do not know whether these things, or any of them, happened in this way. I give you the versions current in London and believed in London. They help explain how it is that Mr. Morgan's prestige has grown in England to its present height ; not among men of finance only but with the general public. Such mistakes as he has made do not seem to have much diminished it. Napoleon, to whom he and all other masterful men are likened, lost many a battle and finally his throne. Mr. Morgan, too, has lost battles but his fame and authority here in England, where he lost them, were never so great as now.

\section{II}

An English banker said to me :

"Morgan's brain must be built on a plan different from other men's. When a proposal involving a great sum of money and complicated transactions is submitted to us we take time to consider it. We lay the facts and figures before our accountants and experts, who go through the whole and make a report to us. Upon that we come to a decision. But Morgan decides instantly."

Then he gave this illustration.

"He was asked to take charge of a financial operation requiring the transfer of a great property in a foreign country, with drafts in the first instance on New York and then from New York to London; all this at a time when exchange was unsettled and the markets of the world were extremely sensitive. $\mathrm{He}$ 


\section{ANGLO-AMERICAN MEMORIES}

had to calculate commissions and stamps on the transfer and a twofold rate of exchange, and then make up his mind what the price of money was likely to be on the completion of the undertaking. He looked at the papers, computed prices, exchange, middle profits, Government dues, in his head there and then, forecast the state of the market at a date some weeks ahead, and within ten minutes had accepted the proposal. Is it wonderful that he gets business away from us in London, going as slowly as we do?"

I knew of a matter in New York; I believe in connection with enormous traction interests at a time when they were most confused. There, it is true, one of his partners had been at work on the proposal for some time, gone into the details and prepared a statement. This partner asked his overlord one afternoon at the close of business whether he would go into it next morning, adding: "It will take some hours." Said Mr. Morgan :

"No, I go to Washington to-night. Get into my carriage and we will talk it over as I drive home."

Before they had reached Madison Avenue Mr. Morgan had mastered the questions on which his firm had spent weeks, and had given his answer which was an acceptance.

They say he is hard, exacting, and expects from those about him results not excuses. Very likely. A lady who was his wife's guest in Madison Avenue said to him :

"Mr. Morgan, you are kind and charming to us here in the house, but I am told you are not always like that in your office and they are all afraid of you." He flushed, began an answer, cut it short, and finally said :

"I am afraid you are right." 
But now let us see what there is under this adamantine surface.

There came to him one morning during a financial crisis a merchant whom he did not know, or just knew, who said :

"Mr. Morgan, I have no claim on you, but I shall be thankful if you will look at this statement of my affairs. My business is a good one, I am solvent, but the banks, as you know, have shut down on their customers, and if I cannot have half a million by tomorrow morning I must go under. I have come to ask you for the half-million."

We can all imagine what Mr. Morgan's first impulse must have been. But he looked at the man's face, looked at his paper, only a half-sheet, checked himself, and said :

"Come to-morrow morning and you shall have your answer."

When the man arrived next morning Mr. Morgan without a word of greeting touched a bell, and to the clerk who came in said :

"Make out a cheque for half a million dollars to the order of Mr. Z."

And as Mr. Z. began to thank him, Mr. Morgan with a smile held up his hand:

"No, it is a busy day. 'There's no time for that. Good morning."

From what I have said before it may be guessed that Mr. Morgan's knowledge not only of business in its broadest aspects, but in all its particulars, is extraordinary. I had heard business men describe it as extraordinary, and one day I said to him :

"Mr. Morgan, they tell me you know every detail of banking, and can do anybody's work in your office better than the man whose speciality it is." 


\section{ANGLO-AMERICAN MEMORIES}

"Oh, I don't know about better, but what I do know is that I can sit down at any clerk's desk, take up his work where he left it and go on with it."

Presently he added :

"I don't like being at any man's mercy."

I remembered what I had heard the managing partner of a firm of smart tailors in London say :

"I sat four years crosslegged on a board sewing coats and trousers. That is why I am now managing partner. If I did not know how every stitch ought to be put in I could not check the men's work. They are all afraid of me because I know, and they know I know."

Perhaps I may as well explain that I am not writing as I do about Mr. Morgan because we are friends. I have known him a good many years, but I cannot claim more than an acquaintance with him; I hope a friendly acquaintance, but one which leaves me quite free to say what I think ought to be said.

And one thing I wish to say is that Mr. Morgan has done more than any other American in any such position as his to relieve us from the reproach of caring for money and business and for nothing else. It is not merely that his fame as a collector is equal to his fame as a financier. It is that he is known to collect not from ostentation but from real love of art and of books and of his other treasures. And, of course, an intelligent love. He is not the man to deal much in what he does not understand. Expert advice is at his call and, like most private buyers, he must sometimes depend on it, but of pictures and books and the like he has a genuine knowledge and judgment of his own.

Only the other day I heard an interesting opinion on Mr. Morgan's collection, and on Mr. Morgan, from 
an expert. The expert in this case was no dealer but himself a collector, known to every dealer as the best judge of values among private buyers with a perhaps unequalled knowledge of pictures, old silver, and many other works of art ; an authority at Christie's, and in Bond Street, or other streets where the feet of the unwary tread sometimes rashly. He said :

"It is astonishing with what judgment Mr. Morgan buys. His various collections are collections of masterpieces."

I have heard it called in question but any such doubts rest on separate instances and where is the collector who is not sometimes deceived ? The British Museum itself was deceived about the collection of Tanagra figurines, long supposed to be the finest in Europe, and then one morning swept into the cellars, where they now repose, by the stern verdict of a French critic. I have heard of Mr. Morgan buying for 20,000 francs at Aix-les-Bains a collection of " old" ivories for which the dealer first asked 60,000. For the moment it scems not to have occurred to him that the difference between the asking price and the price taken was too great, had they been in fact old. No man's business acumen is always alert. All over Europe the dealers are lying in wait for Mr. Morgan, and well he knows it ; and well he knows the truth of Talleyrand's saying-it is quoted in Sainte-Beuve's monograph on him-that everybody's wit is more than a match for anybody's; sometimes.

Mr. Morgan knew the late Baron Alphonse de Rothschild and must, I suppose, have seen that great collector's marvellous collection in the Rue St. Florentin in Paris. His was long the first name in Europe in finance, and one of the first as a connoisseur. But listen to a little story long told with relish in art circles 


\section{ANGLO-AMERICAN MEMORIES}

all over Europe. The Baron was looking at an objet d'art in a certain shop in Vienna which the dealer pressed him to buy. Finally the Baron said:

"No. I have no doubt you think it all right but I am not quite sure, and you know I never admit into my collection a piece about the authenticity of which there is any doubt."

Upon which the dealer lost his temper :

"Monsieur le Baron, I know the contrary. I know of five pieces in your galleries which are not old nor genuine, but modern copies. I know it because I sold them to you."

Nothing so tragic as that ever befell Mr. Morgan, yet there comes now and then into the face of a famous dealer an expression from which you infer he might have an anecdote to relate if he would. If a man tells you he has never had a fall in the hunting field, you conclude he has never ridden hard to hounds. And a man who has bought immense quantities of art works in many kinds is fortunate if he is misled only now and then.

To this, as to most other rules, Mr. Morgan comes as near being an exception as any man well could. He has flair and he has luck. If you do not believe in luck I will tell you another story.

In the double house at Prince's Gate in London reposed for a long time an imperfect garniture de cheminée in Sèvres of the best period. The complete set was of five pieces and Mr. Morgan had only four. He had ransacked Europe. Every dealer in Sèvres knew of it and was on the look out, but Mr. Morgan had relinquished all hope of finding the fifth. One evening just before dinner the bell rang and the servant brought up a message that a man at the door with a parcel wished to see Mr. Morgan. 
"Send him away," was the answer. But as the door was closing Mr. Morgan, from pure caprice or impulse as he described it but really from an inspiration, called the servant back and told him to bring up the parcel. There at last was the missing fifth piece of the garniture de cheminée. "Now bring the man up." He came.
"You wish to sell this?"
"Yes."
"How much?"

The man named the price. "I was not sure," said Mr. Morgan, "I had so much money in the house, but the sum was got together and paid and a receipt taken." Then he asked :

"Had you any particular reason for bringing this to me?"

"No, sir, except that I had heard of you as a buyer of good things and this is very fine Sèvres."

"Yes, I am aware of that. Good evening."

If that was not luck, what was it ? But " luck comes to him who with foresight, with patient courage, awaits his opportunity." However that may be, Mr. Morgan, who has had his fair share of what the gods have to bestow, sets much store by his completed set of Sèvres. He has, as every man who buys much comes sooner or later to have, the love of the chase. In a buyer devoid of a love for art this passion degenerates into an appetite for mere acquisition. Not so with him. No doubt he likes, in the phrase of an earlier buyer, "getting it away from the other fellow," but his real delight is not so much in acquisition as in possession and enjoyment. And except for the public service these rival accumulators do by rescuing good things from destruction, it is this, and this only, which makes their ambitions respectable. 


\section{ANGLO-AMERICAN MEMORIES}

\section{III}

There is, however, one other motive which makes collecting respectable, and that is the willingness to share with the public. Mr. Morgan is a conspicuous instance of that but other instances are innumerable, in England most of all. The Englishman who has a fine place or a fine gallery throws it open to the public, as a rule, once or twice a week, and the public tramps through and gets as much good from it as it knows how. He does that, and from time to time strips his walls to lend to the yearly Winter Exhibition at the Royal Academy, which the late Lord Leighton originated. But I can think of no other than Mr. Morgan whose generosities of this kind benefit two hemispheres. South Kensington in London and the Metropolitan Museum in New York are his debtors in like degree. His gifts are many and his loans are almost gifts.

There were discontented critics who used to complain that Mr. Morgan left so many of his art possessions in England. A late Secretary of the Treasury, Mr. Shaw, was one of them. He said :

"Morgan, why don't you bring your pictures and miniatures and the rest to America, where the American people can have a look at them ?"

"I can't afford to."

"Well, I knew you were a poor man but I didn't know you were so poor as all that."

"Mr. Shaw, how much do you suppose your duties on my collection would amount to if they passed through the New York Custom House ?"

"I don't know-perhaps $\$ 200,000$ or $\$ 300,000 . "$ "At least $\$ 6,000,000 ! "$

So the Secretary of the Treasury dropped that 
subject. How much the recent alteration in the tariff on antiques might diminish these official extortions I do not know, but the reduction must be large. It is a moment which tempts one to say something about the effect of the present New York Collector's administration on European opinion, but I pass on. Nor do I see why Mr. Morgan may not be allowed to have art treasures about him in his London home as well as in New York, unless it should occur to Mr. Loeb to exact a fine on the pictures their possessor does not import.

They say Mr. Morgan has put up the price of pictures in Europe. They said the same thing of the Rothschilds when Lord Rothschild and Baron Ferdinand went into the market for Gainsboroughs and Sir Joshuas. Quite truly. Mr. Alfred Rothschild has done much the same thing for Paters and Lancrets, as Sir Richard Wallace did before him for Greuzes and Fragonards and many other masters. Tring Park and Waddesdon and Halton, and the prices at Christie's compared with the prices thirty years ago, are the best evidences of these competing influences. Mr. Morgan has done his share. He has been, perhaps, the boldest and most persistent of them all. A Paris dealer, if he is in the mood, will tell you that no very long time ago he parted with three pictures to Mr. Morgan at Mr. Morgan's own price. There had been negotiations. Then, one pleasant morning, the American walked into the Frenchman's shop.

"I will take those three pictures. I will not buy any one of them separately. I will pay you $\$ 1,000,000$ for the three, and they are to be packed and sent to London at once. Good morning."

The story, I dare say, like other stories, gains something in the telling since it is the dealer who tells it. He hesitated, he says. He had not sold the pictures. 


\section{ANGLO-AMERICAN MEMORIES}

Mr. Morgan had bought them. The dealer had neither accepted nor refused. No payment had been made. But in the course of the next few days the pictures were delivered at Prince's Gate.

Mr. Morgan is not the type of collector who collects slowly and singly and tastes as he goes along. Not like Sauvageot, who on a Civil Service salary of $\$ 600$ a year left when he died works of art valued at $\$ 600,000$, now in the Louvre, to which he bequeathed them at half price. Nor, on the other hand, like Chauchard, who seems to have made his picture buying a means of advertising his shop. Mr. Morgan has his own ideas and methods. He is Morgan and nobody else. His range is perhaps wider than anybody's else. In pictures and many other art-works the late Sir Richard Wallace may have rivalled him. Hertford House to-day contains, I suppose, the most miscellaneous private collection in Europe; everything first rate in its kind, even including armour. But of Mr. Morgan this may be said. He has :

One of the finest private collections of pictures in the world, and beyond question finer than any other American owner's.

The finest collection of miniatures.

The finest collection of glass.

The finest collection of such porcelain as he cares for.

The finest collection of modern authors' manuscripts.

And the finest private library in the world, of which the manuscripts are part.

If there was an exception to this last statement it was the late Duc d'Aumale's library, in the Domaine of Chantilly. But that is no longer private for it is now dedicated to public uses. In his lifetime the Duke would show it to anybody who seemed interested 
in rare and beautiful books. But he had his own way of showing it. He stood by you. The books were in glass cases, locked. If you asked to see a particular book he unlocked the case, took down the book, opened and turned it over for you to see ; or showed you the binding and discoursed on that. Into your hands the book never passed. Mr. Morgan has no Domaine of Chantilly, nor has America anything like it, but he has built next to his Madison Avenue house a white marble gem of a library which of itself ought to have been included in the list above of the finest things possessed by the private collector. The late Mr. Miller McKim was the architect of it, whom I will venture to call the first architect of his time in America ; one of the first and most accomplished anywhere. He put his best talent and his art genius at Mr. Morgan's service.

It was said of Richard Heber that he did not buy books; he bought libraries. It is not the best way, but it may sometimes be the only way for a man whose life is crowded with multifarious interests. Certainly Mr. Morgan made no mistake when he bought the Gosford library. Of this he had an illustrated catalogue made, privately printed, in large quarto, 192 pages, bound in levant morocco, gros grain, by the "Club Bindery"; curiously lettered on the back, "J. P. Morgan Library. J. Toovey Collection"; in separate panels; and at the bottom, "New York, I90." I ought not to criticize, for my copy of this beautiful volume is a gift from Mr. Morgan. Nor is there much to criticize. The title runs thus: "Catalogue of a Collection of Books formed by James Toovey, principally from the Library of the Earl of Gosford. The property of J. Pierpont Morgan, New York, I90I." Which is not quite correct. The truth 


\section{ANGLO-AMERICAN MEMORIES}

is that the late Mr. James 'Toovey, a Piccadilly bookseller of none too savoury renown, bought the Gosford Library en bloc. This is sufficiently stated in the Preface. He added other books and the whole was sold to Mr. Morgan by the son of Mr. Toovey; I imagine, with the condition that the bookseller's name should be given.

The Aldines are "alphabetized" by themselves, and most of the Aldine rarities are there; the rare first Aldine Horace, 1501, the much rarer first Virgil, I 5 OI, perhaps rarest of all Aldines in fine condition; the first Homer, 1504, and many more; for the most part fine copies though some are in modern bindings. They fill 67 pages; the remaining 125 are devoted to books in general literature. The descriptions are concise, not always so full as one would like but done with a precision rare if not unique in English book catalogues on a French model. The coloured illustrations of bindings, I take it, are also French, probably by Danel of Lille. I know of no English artist who can reproduce as Danel does the tones and the very texture and surface of old morocco and old gilding. As a whole, this catalogue is so excellent that the production of it may be ranked among Mr. Morgan's many contributions to the art-education of his countrymen.

Here again it is true that Mr. Morgan follows the golden rule of buying what he likes and understands. Listen to him as he talks and you will be in no doubt. If he thinks you care for such things he will begin on manuscripts or books or pictures in those hours when a man unburdens his soul; hours of leisure which most business men consecrate to business and he does not. I have heard him, and know. If you have a subject of your own you will very likely find it is his 


\section{MR. PIERPONT MORGAN}

subject also, and he is ready to meet you. But the hour or two after dinner offers a choice of opportunities. If his hostess prefers bridge he will play bridge; well, but not too well. Except Mr. W. K. Vanderbilt, I can think of no great bridge player who is great in other matters also. They say Mr. Morgan does not like losing. Who does? In the game of life it is his habit to win. True, one ornament of the English peerage might be named who inherited a few years ago a considerable fortune, of which the first half is already gone, at baccarat, trente-et-quarante, and in other not less easy ways. But when he has had a bad night he says, "Yes, but I have had a good gamble," and goes to bed content.

When I think a little about Mr. Morgan I remember what the late Mr. W. H. Vanderbilt said to Mr. Mills. Mr. Vanderbilt had recently made some twenty odd millions in a single " deal " in Wall Street ; probably risking his whole fortune to do it. Mr. Mills said :

"You seem to like making money, Mr. Vanderbilt."

The railway king of that day reflected and answered :

"No, I don't know that I do, particularly."

The next time they met Mr. Vanderbilt remarked :

"I have been turning over what you said, Mr. Mills, and I don't even now think I care much about money, but I admit I like to see a good balance-sheet at the end of the year."

I do not ask whether Mr. Morgan does, for, if I understand him at all, what he cares for is power. He is by nature a king of men, and the authority of a king, or in these days of an Emperor with a moustache, is what he likes to possess and use.

He and the Emperor with the moustache have met. It would be interesting to know what each thought of 


\section{ANGLO-AMERICAN MEMORIES}

the other, but one of the two is a man who keeps his private thoughts to himself and the other's views are not for publication. They say the German Emperor knows a man when he sees him. Mr. Morgan has an imperial authority of his own, an ascendancy neither of divine right nor by any process of election. All the same, he reigns and rules. President Roosevelt, in the plenitude of his autocratic power, measured himself against the Wall Street financier and it was not the President who had the best of that encounter. Mr. Morgan's services to his country have not been primarily political, though he has been known to take a hand in that game when not occupied with things more important. But the services have none the less been services; frequent, far-reaching, beneficent. His is the kind of patriotism which dispenses with publicity. He does not seem to believe in that government by newspapers on which Jefferson set so high a value; though he is said to consider a newspaper a useful instrument of finance. Alone, or almost alone, among men foremost in public life he refuses to be "interviewed." The reporters never cease to pursue him and their reward is the pleasure of pursuit. Never a word falls from his lips. If he wishes to influence the market he has other means. To public opinion he makes no appeal, or none by the usual methods. It is not necessary to ask whether any force in the world's finance has been equal to his. It is sufficient to say that in no man's hands has rested the control of such vast money resources; the absolute control and freedom to use so many hundreds of millions. That position he created. His power is personal. It was not inherited. It cannot be bequeathed. It must die with him but the memory of it will never die. 


\section{CHAPTER XXII}

\section{MR. ANDREW CARNEGIE}

I

MR. CARNEGIE AND HIS DEAL WITH MR. PIERPONT MORGAN

A NOTE arrived early one morning which ran thus:

"If you will come to lunch at I.30 to-day I shall have something to tell you which I think you may like to hear.-A. C."

I went and found Mr. Carnegie alone. He was living at the time in, I think, West $55^{\text {th }}$ Street. I say I think bccause I never felt it possible to be sure of an address in New York without referring to one of those extremely expensive directories or registers for which the New York public joyfully pays fantastic prices. A London Court Guide or Royal Blue Book costs five shillings, the equivalent of \$1.25. The corresponding Social Register in New York, containing much less matter, is published at $\$ 5$. Perhaps because the apparently simple but really complicated system of street numbering makes it an article of necessity. Mr. Halstead used to say :

"I never know your address. Sometimes I can remember the number of your street, and sometimes the number of your house, but I can never remember the two together at the same time."

When Mr. Carnegie's note came I was living in rooms at the Renaissance, an apartment house which 
was, I believe, at the corner of Fifth Avenue and West 43rd Street; unless it was East 43 rd Street; or perhaps East or West 45th Street. But at the time I knew, and nearly always remembered where I lived, and I knew where Mr. Carnegie lived because I had been there pretty often, and his address was on the top of his notepaper.

All this may seem in the nature of a stage aside, but is really very pertinent to my story, since my story deals with figures, and since Mr. Carnegie had not then built himself that great barracks of a house between 9oth and 9ist Streets, in Fifth Avenue, or between 9ist and 92nd, or some other streets out of the arithmetic. He and lunch were waiting when I came in, and he began at once; like the man of business he is and always has been :

"I have sold the Homestead Works and all my steel interests to Pierpont Morgan."

There had been rumours for some days of an impending "deal," but the surprise was none the less complete. Mr. Carnegie, always mindful of effects and impressions, regarded with evident pleasure the look of a mazement there must have been on my face. Amazement because Mr. Carnegie and Pittsburg and the steel industry had always seemed to us all identical, or indissolubly bound up each with the other. And here was Mr. Pierpont Morgan coming in like a divorce court judge to put asunder those whom circumstances and long years had joined together.

Mr. Carnegie went on with his story as we lunched. At that time it was all new, of course. So much of it has since become known that I need not go very far into those figures which, as I said before, I find, so perplexing. I will sum it all up in one of those tremendous sentences which, though they stupefy the 
ordinary mind, are so much mother's milk to a man like Carnegie, accustomed to think in millions. He said : "I suppose you would like to know the price. I have sold at a price which secures to me a yearly income, from this source alone, of $\{3,250,000 . "$

The world spun round as he named the sum. It is always spinning round, but it spun a little faster than usual for a minute or two. Mr. Carnegie, you will observe, thinks not only in millions but in sterling. To that extent he has remained a British subject. In dollars the figure of his yearly income works out, roundly, at $\$ 16,250,000$. Needless to say that there has been in all the history of the world no other such fortune purely industrial.

I asked whether the transaction was complete.

"Practically, yes. But no papers have passed. It takes time to prepare papers. But Mr. Morgan and I talked the thing over yesterday and came to terms."

'Then, still with an eye to stage management, $\mathrm{Mr}$. Carnegic paused; then added:

"There is nothing in writing. Everything between us has been by word of mouth."

"But you must have put a few figures on paper, if nothing else."

"No, not one. If either of us should die to-night the deal would be off."

Happily, neither of them did die that night. The agreement was put in legal shape. The papers of the Steel Corporation were also put in legal shape by Mr. Victor Morawetz and Mr. Lynde Stetson. It took them just eleven days to do it. Unless one of the two should object, I will go so far as to say that I was told afterward, on authority it would not be easy to dispute, that their fee for these eleven days' work was $\$ 500,000$. I dare say that seems moderate in $\mathrm{Ncw}$ 


\section{ANGLO-AMERICAN MEMORIES}

York, where legal services are paid at a rate, and in a manner, unknown in London. But when I have told the story in London it has not always been believed.

Even when I explain that Mr. Morawetz and Mr. Stetson are at the summit of their profession the Londoner is still incredulous. Then I am driven to explain further that one reason for the great sums paid to these gentlemen and to Mr. Olney and to Mr. Root and others of that rank-there are not many-is that the deeds they draw are in fact insurance policies; that the great corporations are willing to pay great prices because it is understood that the instruments thus framed are to go through the fire of litigation and come out unscathed. To a still sceptical Englishman I have sometimes quoted the saying of a great financier in New York, whose name you will search these pages for in vain :

"When we put a new enterprise on the market the difficulty is not in finding the capital but in keeping inside the law."

A memorable declaration even when you put wholly aside, as of course we all do, all the sinister meanings to which the words lend themselves.

It was, I understood, Mr. Morgan who had proposed to buy, and not Mr. Carnegie who had proposed to sell. It may not much matter. Their minds met with the ease natural to men to whom great affairs and quick decisions and all-embracing views of complicated questions are of daily occurrence. Whenever anything has to be said of Mr. Morgan, whom I put among the really great men $I$ have known, this transaction must ever be reckoned high up among those on which his immense fame is built. 'There have been, I suppose, moments in the history of the United States Steel Corporation when the outside world-or shall I say 
Wall Street ?-considered that Mr. Carnegie had the best of this deal. Fleeting moments which now belong to history and connect themselves with many outside circumstances.

There was, at any rate, as I talked with Mr. Carnegie, no sign of exultation in the sense of having got the better of Mr. Morgan. These two great powers had met and made a treaty, a treaty which involved neither surrender nor discredit. There are such treaties. Franklin, prone to epigrams and proud of his diplomacy, said in his letter to Josiah Quincy, "There never was a good war or a bad peace." But that is a professional opinion; the sort of thing that $\mathrm{Mr}$. Bright also used to say; not an historical statement but a pious aspiration. Mr. Bright was less sweeping than Franklin. He said to me :

"There has been no just war since William III, except your war for the Union, and that was forced on you."

In Franklin's mind lurked the thought that peace and not war was the work and the object of diplomacy. But it is by no means always so.

Mr. Carnegie continued :

"I take bonds in payment; 5 per cent bonds secured upon the entire property of all the seven corporations [afterward eight] which merge in the Stecl Corporation. I think I know pretty well what they are all worth, and if there's a better security anywhere than my mortgage will be I don't know where."

It may be noted that one of the parties to this great bargain was a man of Wall Street. Mr. Carnegie, of course, is not, and he is sometimes quoted as not liking Wall Street or its methods. I have heard him say:

"Bring me your money and I will give you 5 per cent for it. Don't speculate. I have never bought a 


\section{ANGLO-AMERICAN MEMORIES}

share or stock for the rise nor sold for the fall. It is an agreement with my partners that no one of them shall speculate."

So it is evident he is not a prepossessed witness in favour of any of the Wall Street group. But when I said to him, "You trust Morgan's word," he answered :

"Yes, but Morgan is Morgan."

And perhaps even Mr. Roosevelt, who admits, or did admit, that there are good trusts as well as bad trusts, would admit, or would once have admitted, that there are men in Wall Street to whom honour and good faith and business probity mean what they mean to men elsewhere.

It was evident that much of what Mr. Carnegie said to me was intended to be cabled to $\mathcal{T}$ be $\mathcal{T}$ imes, and that some of it was not meant to be was equally evident. When I said so to him he answered in almost the very words Prince Bismarck had used in similar circumstances :

"It is for you to distinguish."

But as this was a matter of business and figures, I said to Mr. Carnegie I would send him a copy of my dispatch to look at before it went. I sent it at four o'clock by messenger, asking him to let me have it before six, the hour at which, as a rule, long dispatches to London had to be filed, six in New York being eleven at night in London. It came back at 4.30 , with an inscription at the bottom :

"O. K.-A. C."

Which I thought so interesting that I kept the original and handed a copy to the cable messenger. And I imagine there has seldom been a business dispatch which has so stirred the business world of London as this account of the great treaty between $\mathrm{Mr}$. Morgan and Mr. Carnegie. 


\section{II}

MR. CARNEGIE AS CAPTAIN OF INDUSTRY, AS APOSTLE OF PEACE, AND OTHERWISE

Deep down in the hearts of most men lurk superstitions about their fellow-men whose good fortune, or what seems to them such, is above the average. The belief in wizardry of one kind or another has never died out. With respect to Mr. Carnegie it took a form which perhaps did not wholly displease him, since it tended to establish a belief in his omniscience. It was said of him, for example, that he knew all about metallurgy, chemistry, mechanics, and other sciences and processes which had to do with the making of steel. I asked him, at a favourable moment, whether this was true or how far true. He answered:

"It is not true at all. I know nothing about any of these matters. That is, I have no exact knowledge on which I should build an opinion or judgment of my own and act on it. The secret of my method and my success is simple. I organize my business into departments. I put the best man I can find at the head of each department, hold him responsible, and judge him by results. And I think the results prove that I have been a pretty good judge of men."

I once put a similar question to Mr. Picrpont Morgan but that will be found in its place elsewhere. Mr. Carnegie's system was a good system so long as he was at the head of it. He had a directing mind and a deciding power, both in a supreme degree ; qualitics for want of which many a business goes to pieces. What happened when he left the steel 


\section{ANGLO-AMERICAN MEMORIES}

business to take care of itself may be seen from the account I am going to quote; an account, it should be understood, which relates to the early days of the Steel Corporation. Mr. Carnegie had asked me to go with him as his guest to a St. Andrew's dinner in New York, over which he was to preside. $\mathrm{He}$ there introduced me to one of those heads of departments above mentioned; an appointee of his own. I have forgotten both the name of this gentleman and the name of his department, and the story is better without either. He talked to me for a long time about the Homestead Works, and how and why the business had prospered. His story bore out what Mr. Carnegie had said, and strengthened it. As you listened to him you could not doubt that Mr. Carnegie was the soul and source of its prosperity. Finally I asked him how things were going under the new Corporation. He gave me an answer which I thought striking :

"They are not going quite so well, and I will tell you why. The business formerly had one head, one executive authority. Now it has several. In the old days a message would come from Mr. Carnegie that he wanted to see me, or perhaps I had a scheme in my head which I wanted to submit to him. I will give you as an illustration a department with which I had nothing to do.

"I had become convinced that we wanted, let us say, a new wharf and warehouses at the port. When I went to Mr. Carnegie I went with a complete statement of reasons; with plans and estimates also complete. I stated my case and laid the papers before him. He was a good listener, but asked questions at the critical points and the answers had to be ready. When I had finished he said: 'Leave the papers 
and come to-morrow morning at ten o'clock.' At ten o'clock next morning he said yes or no. If yes, he expected the work to be begun at once. I was in charge, and there would be no occasion to trouble Mr. Carnegie again until I was in a position to ask him to inspect the completed wharf and warehouses.

"Whereas now, I must lay my proposal, as a proposal, before the manager, who in turn lays it before the local board of directors, who in their turn lay it before the general board at New York, who consider it at their next meeting, whenever that may be. All this may take three or four weeks or more, the necessity all the while urgent in the face of competition and the time lost much diminishing the competitive value of the improvement. But this is the routine through which every important proposal has now to pass. There is not a man of us who would not like to have Mr. Carnegie back again."

Whether this narrative may help explain why Steel common at a certain moment stood at eight, I cannot say, nor whether a return to Mr. Carnegie's methods had anything to do with its rise later, or the immense prosperity to which the new concern presently attained. The story interested me, and is told to you as a tribute to Mr. Carnegie.

It is, I suppose, since Mr. Carnegie retired from the steel-making business that the world has heard most of the stecl-maker. His libraries, his later gifts of great sums of money to other objects, his apostleships, his dual existence in Scotland and in the United States, and, last of all, his ten millions to promote, or for aught I know to establish, the peace of the world-all these are so many jets of limelight turned one after the other on a figure in the centre of the stage. I shall have nothing to say about any of them 


\section{ANGLO-AMERICAN MEMORIES}

except where I happen to have known something not of common knowledge. I did at one time mean to write an article on $\mathrm{Mr}$. Carnegie in one of the English reviews, and asked him for material. $\mathrm{He}$ kindly sent me a large parcel of books and I know not what else. But on considering the matter I gave up this plan and left the parcel of books unopened. It remains unopened. I found that my article would be too critical, or more critical than I wanted or meant it to be. I admire Mr. Carnegie's capacity for enthusiasm, but his enthusiasms are not mine. There are few great public questions on which I have been able to agree with him, nor can I see any clear sign that the English public or the American public agrees with him or is disposed to accept his leadership.

It was a long time before Mr. Carnegie was taken seriously in England as a teacher. I am not sure that that time has yet arrived. Even the splendid list of ambassadors and other public officers whom he has secured as trustees for his Peace Fund does not convince Englishmen that his is anything more than a counsel of perfection; a pious opinion. The English have made their way in the world and built the British Empire by hard fighting. When Mr. Carnegie tells them that war is barbaric they ask: "Was Wellington a barbarian? Was Nelson? Was Clive? Is Kitchener?" They will do what they can to keep the peace in the future, but they do not care to renounce their heroes nor their history. They approve of arbitration in some things, but there are certain questions they will never, no matter what treaties they sign, submit to arbitration, and if challenged on vital matters they will neither submit them to arbitration nor will they surrender, but will fight; and fight as hard as ever they did, and as well. 
Mr. Carnegie cannot change human nature, nor turn a warlike race into litigants at The Hague.

Mr. Gladstone, a great name often in Mr. Carnegie's mouth, was supposed to wish for peace, and no doubt did. But there were other things he wished for more. His notion of peace was to be ready for war. Why did he ask the House of Commons to vote six millions sterling in 1870 when Belgium was thought to be menaced? Why did he ask for $f_{1} \mathrm{r}, 000,000$ at the time of the Penjdeh quarrel with Russia, and tell the House " the book is not yet closed"? And what did he mean to do with the money which the House voted unanimously?

Lord Morley has always been a great authority with Mr. Carnegie. He said :

"Don't make any mistake. Mr. Gladstone is anything but a peace-at-any-price Minister. $\mathrm{He}$ will fight as readily as Palmerston or Pitt, though perhaps for different objects; and once in for a war, he would fight to the end."

And I should say of Lord Morley himself what he said of Gladstone. That same Penjdeh incident proved it. True, it was arranged and there was no war, though for some weeks the two great empires stood on the brink of war. But when the Emperor of Russia gave a jewelled sword to General Komaroff, who had been the chief agent in that perfidious aggression, Mr. Morley was asked how he liked it, and answered:

"Like it ? I should like to cram lis jewelled sword down his Russian throat."

Strong language? It is. But the language actually used was stronger still. And I never liked Morley better nor respected him more than when he used it. It would not prevent him from being one of 


\section{ANGLO-AMERICAN MEMORIES}

Mr. Carnegie's Peace 'Trustees, but it would prevent him from tying his hands by any pledge meant to restrict his right of appealing in all circumstances to the ultima ratio of war. Make it as infrequent as possible but you can never make it impossible; that, I think, would be Lord Morley's answer to his Scotch-American friend.

I have long known Lord Morley and Mr. Carnegie as friends; a friendship, like so many others, cemented by unlikenesses; the friendship of a man of business for a scholar; of a man of impulses for a patient thinker bent on going to the bottom of things; of a strongly self-confident man for a man alike of singular modesty and invincible convictions. Lord Morley's influence over Mr. Carnegie is, as it was over Mr. Gladstone, intellectual. Mr. Gladstone recognized a kindred spirit. He could appreciate as few could the extraordinary range and precision of Morley's knowledge and the use he made of his mind. Mr. Carnegie's recognition of these qualities was less complete than Mr. Gladstone's, and I rather imagine he supposed Lord Morley his pupil in politics; which was not quite so. I remember an instance. There was a crisis in Westminster as to which $\mathrm{Mr}$. Carnegie held strong views; as he did on most subjects whether he had found time to think them completely out or not. Morley was in Russia. Mr. Carnegie telegraphed him very urgently.

"But," said Mr. Carnegie, in a tone of surprised dismay, "I cannot make Morley understand how important it is he should return at once and take his proper part in this contest. Still less can I understand his reluctance to accept my view."

A little anecdote which gives you a glimpse, not complete but clear of both men. 
It was Mr. Carnegie's desire that Mr. Morley, some years ago, should come to America and explain to the American people what they ought to think about "Progress" and other related topics. He asked Morley to come as his guest, and Morley, though certainly taking a less didactic view of his mission, accepted Mr. Carnegie's invitation and came. There was a celebration at the opening, I think, of the Institute at Pittsburg, and before a Pittsburg audience Mr. Morley delivered his address. It was a piece of high thinking. The people of Pittsburg, having resolved to take serious views of life-of intellectual and art life as well as of industry and business-welcomed Mr. Morley, of whom some had heard before and all now heard from Mr. Carnegic whose dictatorship in the Iron City was irresistible. They duly applauded the orator, and it was plain that the dictator had chosen his man wisely.

But Mr. Carnegic wished it to be understood that Mr. Morley came to America not only as orator on Progress but as an Ambassador in Literature; a part for which no other living Englishman was so fit. He arranged therefore that distinguished and some undistinguished Americans should meet him elsewhere than on the platform. About one of these receptions I will venture to say a word.

\section{III}

MR. CARNEGIE AND LORD MORLEY-THE LATE KING AT SKIBO-A PITTSBURG STORY

The dinner, or this particular dinner, which $\mathrm{Mr}$. Carnegie gave Mr. Morley was like no other dinner 


\section{ANGLO-AMERICAN MEMORIES}

ever given by anybody to anybody. Not large enough to be called public, but yet not private. It was given in Mr. Carnegie's house in Fifth Avenue, and we sat down twenty-two persons. I think what our host intended was that English and American literatures should meet and exchange greetings. There were, however, on the American side men eminent in other things than literature; such as Arms, Law, and Journalism. Mr. Carnegie, unhappily, was ill upstairs and could not appear. With one of those graceful intuitions which make women what they are in society, Mrs. Carnegie took her husband's place. There was no other lady. Dinner over, she rose, bade us goodbye, and appointed Mr. Gilder to preside.

In front of each guest lay an engraved extract from some book or other writing of Mr. Morley; each quotation different, but each with an engraved request that the guest would take the passage before him as the text of his speech. Mr. Gilder and Mr. Morley alone were free to talk on what they liked. Mr. Gilder presented - as if he were Mr. Charles FrohmanMr. Morley in a few words chosen with the scholastic care characteristic of Mr. Gilder. Then Mr. Morley, not wholly free from embarrassment, spoke rather briefly but, as ever, weightily and, as ever, expressing the thought which was his own in that language of literature from which neither politics nor society ever wholly withdraws him.

I know not how to go on. I will do nothing beyond chronicling the fact that of the twenty-two men present seventeen spoke. But for once the exuberance of American after-dinner oratory was kept in check. There were men present of a distinction such that in ordinary circumstances they would have thought themselves entitled to not less than half an hour apiece. 
With a tact for which no praise could be too high, they contented themselves with a modest five or ten minutes. As I listened I remember hoping that each speaker felt, as each listener felt, how much each little discourse gained by condensation. Probably they did, since the characters of speaker and listener were continually interchangeable. Every now and again I looked at Mr. Morley. He had no notion what he was to expect, and as presently it dawned upon him that Mr. Carnegie had required a speech from almost every one of his guests there came over Mr. Morley's benignant face an expression of pleased bewilderment which had about it something of religious beauty. The Christian virtues, for that night at any rate, were his.

It was a scene which could have occurred nowhere but in America and perhaps nowhere in America except under Mr. Carnegie's roof. I have never told the story in England. I was sure no Englishman would believe me. I don't know whether Mr. Morley ever told it. His rigorous accuracy of mind might convince, yet an Englishman's power of belief in novelties is never very great, and the notion of seventeen speeches at a semi-private dinner would have seemed to him all but incredible. Yet had this same sceptical Englishman been there he would have spent an evening of fresh impressions and agreeable social relations such as might have induced him to reconsider his fixed conceptions of hospitality.

Mr. Morley was delighted with the views of American life which Mr. Carnegie presented to him. He had, however, a wish to see something of that social fabric which exists for its own sake, and a friend who knew of this wish arranged a luncheon for him at Sherry's, which included two of the women whom everybody would recognize, by their names and other- 
wise, as leaders in New York society. There were two others of the same class and two men like unto them. Mr. Morley sat between the two ladies first mentioned whom he met, as he did the others, for the first time, and his pleasure was plain to see. As we walked away together after luncheon, he said:

"Pray have you many women in New York of the force and beauty of Mrs. X ? And I might ask the same question about any of the others."

If Mr. Carnegie will forgive one intrusion into more or less private life, perhaps he will forgive another. He must know how keen American curiosity about Skibo is and that, often as it has been gratified, it is still keen. I am not going to describe the castle which I have seen only once. All I can offer you is an impression. Mr. Winston Churchill and I were staying at Dunrobin, fourteen miles away, and telephoned one morning to ask if we might come to luncheon. We motored over, partly in the belief that we should find Mr. Morley at Skibo; but he had gone. We found instead a group of guests, all unknown to us, and ail with unusual gifts of silence.

Skibo was once old and I believe Mr. Carnegic would have liked to keep it old; but his architect warned him there was no compromise between leaving it a ruin and rebuilding from the foundations. $\mathrm{He}$ chose the latter, and the result is that Skibo is probably the newest old castle in the world. Mr. Carnegie is modern and his castle is modern. It is an expression of Mr. Carnegie. He is a man who knows what he likes and generally gets it. He likes comfort, his own sort of comfort; why should he not have it? What feudal chieftain or what ancient Laird of Skibo would have thought of building a swimming-bath ninety feet long? But Mr. Carnegic, to whom everything feudal 
is alien, thought of it, and built it, and there it is today. And many other things are there to-day, just as free as the bath is from the feudal stamp. The modern upholsterer has replaced the Highland robber.

The library interested me most. There are some five-and-twenty thousand volumes all chosen by the late Lord Acton, and what could be more stimulating than to look over the collection of books which Lord Acton had thought suitable as a library for $\mathrm{Mr}$. Carnegie? You saw the meeting of two minds, each highly remarkable and as unlike as it was possible for two minds to be. Lord Acton was once asked how much he read daily, on an average, and his answer was :

"One big octavo volume a day, most likely in German, beside odds and ends."

Mr. Carnegie, as we all know, has read much and written much, excellently well, but until quite recently the world knew him, since his retirement from business, as a creator of libraries, or at least of library buildings. I asked him that morning how many he had given away during that month which was nearing its end. He rang for his secretary who said: "I will get the list, sir," which presently he laid before us. There were twenty-seven.

There are, of course, men, both scholars and men of the world, who doubt whether Mr. Carnegie has made the best use of his money in scattering library buildings about, which can serve only local uses. Even if you put the fiction question aside, is it worth while to form collections of books in separate towns which can never have any real importance as libraries? Is anything gained by multiplying copies of Hume and Gibbon and Macaulay and other classics which no gentleman's library should be without? Mr. Carnegic, 


\section{ANGLO-AMERICAN MEMORIES}

I know, was urged to make a different use of his money :

"We have in America no Bodleian Library, no British Museum. We have no library to which a specializing student can go with the certainty of finding the books he needs to carry on his studies to the end. If you would found such a library at Yale or Harvard or Columbia, or take the New York Public Library, or the Congressional Library at Washington, and complete them, or one of them, you would serve American scholarship as it can be served in no other way."

But Mr. Carnegie is a Democrat, and applies the principles and dogmas of his political faith to his schemes for the improvement of mankind, and he went his own way as I suppose he always will. And yet it is not too late to try the other way. There is a sense in which the greatest happiness of the greatest number is the happiness of number one. In other words, raise the standard at the top and you lift a whole people with it. But Mr. Carnegie has a faith not only in Democracy but in himself ; which accounts for many of his splendid successes, and perhaps now and then for a failure.

It was in this Acton-Carnegie library that Mr. Carnegie had lately received King Edward, who had been staying at Dunrobin and had motored over for luncheon. It was here that Mr. Carnegie welcomed the King by reciting to him the poem which $\mathrm{Mr}$. Joaquin Miller had composed on the occasion of Mr. Carnegie's birthday. I was shown the poem, emblazoned in colours on stamped cardboard. All about the country-side the story of this poem had been told, or several stories had been told. The King, it was said, did not like Mr. Joaquin Miller's effusion. In 
truth, these verses of the Poet of the Sierras were not conceived in a courtierlike spirit. They began with invocations to the German Emperor, to President Roosevelt, to the King, "Hail fat Edward "_-" That's you, sir," said Mr. Carnegie to the King-and then swept aside all these great personages with Mr. Joaquin Miller's personal assurance that he had rather shake Mr. Carnegie's strong hand than all the others; as if they were all outstretched to him, which they do not appear to have been.

It is true the late King was fat, which did not prevent him from carrying himself with a distinction that proved how little mere physique has to do with dignity and personal charm. His mother had proved it before him. But it is not the custom to dwell on these matters with royalty. There is a story of a man in a shooting party who said to the King as he missed two or three pheasants flying high over his head: "Sir, you are too fat to shoot rocketers." But he was never again asked to shoot with the King; nor perhaps would Mr. Joaquin Miller have been.

I heard both at Skibo and at Dunrobin that Mr. Carnegie was a good landlord and good neighbour. The Duke of Sutherland is reported to have said of him: "Yes, indeed, Carnegie has been a good neighbour to me. He bought a good deal of my land which I wanted to sell and paid me a good price, and I never heard that any of the tenants were the worse for the change. They and all the people about are, indeed, better off than if the land had remained mine, for Carnegie has spent more money on the property than I could, and spent it wisely and kindly."

As the Duke owns something like a million and a half acres, his testimony is to the point ; the more so as he is himself a good and liberal landlord. 


\section{ANGLO-AMERICAN MEMORIES}

In what used to be Mr. Carnegie's proper environment, Pittsburg, I heard a similar account of his relations to those about him and under him. His men knew him as a just master; generous withal, and abounding in human sympathies. If their faith was ever shaken for a moment, it may have been at the time of the great Homestead strike for which a firm hand was needed and found, but not Mr. Carnegie's. $\mathrm{He}$ was away in Scotland. When he returned, order had been restored. He is reported to have said to some of the men :

"Boys, I am sorry all this has happened. Perhaps if I had been here it might not have happened. But I could not go back on my partners, could I ?"

True or not, it is illustrative. With all his masterfulness he knew when to concede, and perhaps when to be in Scotland, and I suppose he never went back on anybody. 


\section{CHAPTER XXIII}

MR. WILLIAM WALDORF ASTOR AND HIS EXPERIENCES IN ENGLAND

IF I say anything about Mr. William Waldorf Astor I shall encounter in the United States, I suppose, a strong prejudice due to his having become a naturalized British subject. But I must risk that. The American point of view is apt to be American. That, however, is not the only point of view. There are others, whether we choose to admit it or not. When a German or Scandinavian casts off his German or Scandinavian nationality and becomes a naturalized American citizen, we welcome him. We do not feel bound to take note of German or Scandinavian protests against his abandonment of his native land. In the case of Germany there are such protests, and very strong protests. For a long time Germany refused to recognize the right of expatriation, and if a naturalized German returned to Germany she compelled him to undergo military conscription as if still a German. Once a German always a German was her motto. It required a treaty, negotiated by the historian Bancroft, then our Minister at Berlin, to relieve him from that obligation. That was the German point of view, and I think we may admit that the German sentiment of nationality and love for the Fatherland is not less strong than the American. 
But since we nevertheless incorporate some millions of Germans, against the general wish of the German people, into our American Republic, need we be so angry with a single American who elects to become an Englishman? We may regret it. We need not revile him.

Why Mr. Astor made this choice is not generally known. Most New Yorkers are aware that his position at home, for reasons I need not go into, was made difficult for him, by no fault of his. At any rate, he resolved to come over here and live. As his children grew up they presented a problem. Were they to be British or American? They were to live in England. If he became a British subject before they were of age, they would be British also. Mr. Astor was quite aware of the criticism which would be made and of the obloquy that would follow upon his decision. But he preferred to take that upon himself rather than let it fall upon his children; and that is why he determined to be naturalized while they were still minors. $\mathrm{He}$ may have been right or wrong but the motive of parental piety to his children is one that we can all respect.

So far as I know, Mr. Astor has made no explanation and has made no answer of any kind to the invective of his American assailants. He is a man with a great firmness of character; a great courage; a great power of enduring in silence what he believes to be unjust censure. If I were to consult him, I imagine he would give no sanction to the statement I am making. But I know the facts from various sources and I use them on my own responsibility. A man's friends may sometimes say for him what he would not say for himself. And if I thought it might a little appease American wrath, I would add that 
MR. WILLIAM WALDORF ASTOR 263

Mr. Astor, even as a British subject, has done much to make the American name respected here. Briton though he be in law, everybody thinks of him as an American, and recognizes as primarily and essentially American those qualities which give him a place apart in this English life. As I knew him in New York, and have known him all through his English experiences, I offer my testimony for what it is worth.

Mrs. Astor was living when her husband chose London as a residence. No one who knew Mrs. Astor could imagine that social ambitions influenced her. It would not be a reproach if they had. Social ambitions are respectable in themselves and many American women have shown us to what brilliant uses they may be turned abroad, and what an impress they leave on English society. Mrs. Astor took the place to which her beauty, her name, her wealth, entitled her, but she took it very quietly and almost indifferently. While they were both in deep mourning for the loss of her father and his, Mr. Astor became the tenant of Lansdowne House; one of the few houses in London standing in its own grounds, and a palace rather than a house. I asked Mrs. Astor why she cared to live in a mansion meant for splendid hospitalities which, in the circumstances, were impossible to them. She answercd :

"Oh, we had looked at many houses, and Lansdowne House is the only one which gave us the two things we most wanted; perfect cleanliness and good nurseries."

There spoke a true simplicity of nature. Later they entertained, but never put the full resources of the place to the test. They went about, of course, among some of the best people, who admired this 


\section{ANGLO-AMERICAN MEMORIES}

American lady's simplicity of nature as they did her beauty. There was a dinner one night at Spencer House, where Mrs. Astor sat on Lord Spencer's left at the end of a table which stretched from end to end of that noble dining-room, with its noble pictures. She was herself the loveliest picture there, and this well-bred company gazed and gazed till even Mrs. Astor became aware of the homage offered her.

Mr. Astor is a man who has ways of his own. He orders his life in accordance with his own notions of what his life ought to be. His tastes are positive tastes and he gratifies them. He built himself a Tudor mansion on the Victoria Embankment not far west of Blackfriars Bridge. This he called at first the "John Jacob Astor Estate Offices," which has now been simplified into "Astor Estate." As a place of business and of American business there's nothing like it cither in New York or London or anywhere clse. It stands back from the roadway and from the river, looking perhaps with its mullioned windows and stained glass and its pointed architecture as much like an art gallery as anything. The office proper is on the right as you enter on the ground floor, and there this vast business of real estate is transacted in an atmosphere of such quiet and seclusion as exists nowhere in New York. The complete records of both the New York and London properties are there, New York sending transcripts week by week. Mr. Astor's sanctum is on the floor above, a great hall, of which the ceiling is the roof; the structural beams and rafters all visible; family portraits on the walls, gilt busts on pedestals, and what we call "Colonial" furniture all about; which I suppose no truly patriotic American 
MR. WILLIAM WALDORF ASTOR 265 will admit to be, as it is, furniture of George III's time. A spacious, well-proportioned baronial hall, with only Mr. Astor's desk to suggest that it is the head-quarters of one of the greatest estates in the world. There is a library of rarities; a bedroom with a François Premier bed in it much too large for the room, in which Mr. Astor sleeps when in London, with his feet in the fireplace; and much else. $\mathrm{He}$ built it to please himself and it is one of the sights of this ancient London; not, I think, often shown nor perhaps well known to the tourists. In Carlton House Terrace, which is supposed to be his private address, Mr. Astor never sleeps. The vast house serves for a certain number, not many, dinners in each season, followed by concerts of which Paderewski is one attraction and Jeannic Granier another, and a long roll of famous names.

When Mr. Astor bought Cliveden from the late Duke of Westminster there was a dispute, of which I suppose some echo found its way across the Atlantic. The Duke, having sold the place with its contents, claimed one item of the contents as still his own, the visitors' book. If he had asked for it he would have had it, but when he made a claim as of right, $\mathrm{Mr}$. Astor stood on his own rights and the two quarrelled, about almost nothing. The Duke of Westminster was a very powerful personage and his friends took his part; and Society, ever respectful to Dukes, was a good deal on his side. The Duke saw fit to make Mrs. Astor a party to the dispute, and wrote her a letter which might better have been left unwritten, and was left unanswered. After keeping the book long enough to assert his right, Mr. Astor sent it to the Duke. Yet the quarrel became a feud and lasted till the Dukc's death. 
The Duke claimed other things more important than his visitors' book. He excepted from the contents which were to pass with the house "a few prints." He interpreted this exception as including prints and pictures to the value of rather more than $£_{10} \mathbf{0}, 00$, as inventoried by his own agent; and these he removed. Mr. Astor could have detained them but he let them go without a word.

Cliveden as the Duke sold it was a beautiful thing; Barry's façade looking down on the gentle Thames from its lofty terrace, amid woods and over fields of a soft multi-coloured greenness only to be seen in perfection in England. Its new owner made it one of the most beautiful possessions anywhere in England or in the world, of its kind. An Englishman of the olden time, or of the modern time with the old traditions still strong in him, might not find it to his taste. It has, or had, not more than three hundred acres of land about it, and any more land that might be bought would be divided from it by high roads. Dropmore, hard by, is much more the English idea of a country place, with its George III house in the midst of three thousand acres of lovely park.

Mr. Astor presently felt this land hunger strongly and sought to enlarge his boundaries, regardless of the high road. I believe he did acquire a certain number of acres but the possessions he coveted were not for sale, even at prices much beyond their market value. One of his neighbours declined a cheque for half a million for but a fraction of the beautiful woods he owned, and still owns. There are men to whom money is not everything, nor even the first thing. In these days of Death Duties and Supertax and Lloyd George Budgets there are landowners 
MR. WILLIAM WALDORF ASTOR 267

who find themselves obliged to sell; and of the next generation there will be many more. But they sell under compulsion. Great estates and old families are to be broken up. It is Mr. Lloyd George's avowed object. The American who cares to see England as it has been for centuries, in all its charm, must not wait too long.

Possibly even Mr. Astor may not now regret that his attempts to make Cliveden a landed property failed. Land is becoming in England the most expensive of all luxuries, and Mr. Astor is, by descent and education, a man of business first of all, and a man of business does not like paying more than a thing is worth. Nor does a man of business, or any man, like being despoiled of his property, whether by the State or by unlegalized brigandage. Nor is the doctrine of ransom, originally Mr. Chamberlain's doctrine, yet accepted by the classes who have to pay it. But those classes are a minority, and the rights of the minority in England are at the mercy of the new majority.

\section{II}

So Mr. Astor, unable to broaden the acreage of Cliveden, applied himself to the beautifying of the house and of such land as there was. I can imagine he found some pleasure in improving upon what the Dukes of Westminster and of Sutherland had left behind them. Their decoration of the interior was an example of the early Victorian manner; commonplace, inartistic, Philistine. He swept all that away except one little room, which he left with its trellis-work and tawdry garlanded cornices 
by way of contrast to the new; perhaps not without a little mischievous pleasure in perpetuating these ducal trivialities.

The great hall and the oaken staircase are now fine specimens of modern work. The library is in some strange wood from the antipodes, the name of which I could never remember. The drawingroom is brilliant Louis XIV; the dining-room an interior from a French château, with at one time a café-chantant ceiling, painted with daring. The bedrooms are models of luxurious comfort. In the hall hang Romneys and Sir Joshuas and other masters; a gallery of art splendours. This is no place for details but not the most careless glance can omit the marble balustrade now edging the terrace, as if with lace; an exquisite piece from the Villa Borghese, the export of which from Italy was strictly forbidden. Mr. Waldo Story has established a group of white marble ladies in charge of the great fountain past which you drive to the entrance, and has adorned the landing and the path to it with fantasies in coloured marble designs, inspired from the Borghese original. A miniature Italian garden and a miniature chapel in gold and mosaic and marble nestle beneath the cliff.

The late Duke of Westminster, whose name has to recur now and then, had a liking for Queen Anne architecture of which his London Mayfair property is the extreme expression. He took it with him to Cliveden. On either side of the approach to Barry's Italian front were two Italian pavilions of grey stone, reaching out with long arms or galleries from the main building toward the fountain. The Duke tore down one of them and built in place of it a red brick parody of a Queen Anne Lodge. Vandalism or a 
MR. WILLIAM WALDORF ASTOR 269 passion for grotesque, architectural ineptitude could not go much further than that. Mr. Astor in his turn tore down the Duke's work and replaced it by a copy of Barry's original. Scarce anything he did could have given him more pleasure than that; or more pleasure to the beholder.

Arriving one Saturday at Cliveden for the weekend, I found the one vacant panel in the hall had been enriched by a Romney, one of that painter's most delicate creations. I was indiscreet enough to ask Mr. Astor of whom he bought it; indiscreet because, in these days of legislative financial embarrassments among the English families possessing such treasures, pictures are sometimes sold on condition that the name of the former owner is not to be revealed. Not, however, in this case. Mr. Astor had bought it of a dealer, whom he named but I do not; a sinister notoricty now attaching to the name.

"It is the first picture I ever bought of him and it will be the last."

"You don't doubt it's a Romney ?"

"Oh no, the picture is all right; it is the price which was all wrong."

That, too, was characteristic of Mr. Astor. $\mathrm{He}$ did not mind paying a good price if he thought he had been fairly dealt with; if not, he closed that book.

Having done all he carcd to with Cliveden, he gave it to his son Waldorf on his marriage with Mrs. Shaw; and there these young people have lived and entertained ever since, the shining centre of a shining circle of brilliant friends. Young Mr. Waldorf arranges his life on independent lines; racing in moderation, and having now found a seat in Parlia- 


\section{ANGLO-AMERICAN MEMORIES}

ment as Unionist Member for Plymouth. He made a speech last session on National Insurance which won him compliments from so great an authority as Mr. Winston Churchill, and has a political career before him should he care to follow it.

Before parting with Cliveden Mr. Astor bought Hever Castle, in the county of Kent, some thirty miles from London. A moated castle, its oldest walls of the thirteenth century, the main fabric Tudor, but with drawbridge, portcullis, and battlements complete. Of no great size, and since $\mathrm{Mr}$. Astor wished to entertain week-end parties the question arose, How to do it ? He had an inspiration of genius. He perceived that to attempt to enlarge the castle would be fatal. He therefore built outside of it a Tudor village, connecting with the castle by a covered bridge and each cottage connecting with the other. Inside, you pass from castle to cottages unaware that they are not all part of the same fabric and beneath the same roof. Thus he houses some five-and-twenty guests. His own rooms are in the castle. Splendours everywhere; galleries filled with objets d'art, Venetian, Florentine, and others ; pictures, furniture, treasures of many lands, all contriving to seem at home in this old English abode and in the home of Anne Boleyn. It is her name and names associated with hers that give an historical interest to this venerable pile, which has been restored to something like what it was when that fascinating minx dwelt in it.

Outside, Mr. Astor has built-a word to which Mr. Gladstone objected when I applied it to the Panama Canal-two broad lakes and an Italian pergola, very spacious and imposing. There's an Italian garden, of course; without an Italian garden 
MR. WILLIAM WALDORF ASTOR 27I

and without an atmosphere of Italy about him he could not live. Italy is in his blood, and when he goes to his delicious villa in Sorrento I don't doubt he is more at home than in his Tudor castle, except that he cannot gather about him so many friends. Last summer at Hever he was ill with gout, a painful attack, but when I asked him why he did not abandon these cold clay lands and stone walls and seek the sunshine of Sorrento, he answered :

"But how can I give up these parties of pleasant friends?"

There again spoke the Astor his friends know, if the world does not.

But on Hever, as well as on Cliveden, his hand has rested and his mind has spent its activities till not much more remains to be done. For five years he kept eight hundred men steadily at work on the place, Italy all the time paying him its forbidden tribute till you think there is no room inside for another cup of crystal or another gem of whatever sort. What will he do with it all ?

"Well, I dare say I shall give it to John some day, and then find myself another toy."

Something he must have on which to pour out his quenchless energies; the management of his Astor properties on two sides of the Atlantic leaving him leisure that has to be filled somehow. He fills it in part with literature, using his pen with the vigour he devotes to business. Now and then he buys a newspaper or magazine. The Pall Mall Gazette and The Pall Mall Magazine are his. Quite recently he has done a high public service; buying $T_{b e} \mathrm{Ob}$ server, the foremost of Sunday papers in London, in order to keep Mr. Garvin its editor. Mr. Garvin is the foremost of the younger English editing 


\section{ANGLO-AMERICAN MEMORIES}

journalists, a man of such independence and conviction that he can surrender his convictions to no proprietor, though ready to surrender his editorship. In the crisis which besets this country he has led the thought and put nerve into the purpose of the Conservative chiefs. But there came a moment when the owner of $T$ be Observer and the editor of it differed, and it was supposed Mr. Garvin must go. I could conceive no greater calamity to journalism or to the Conservative cause. Then it was that Mr. Astor bought the paper, asking Mr. Garvin to remain and to conduct it as his conscience ordained.

Since then the Pall Mall Gazette also has passed under Mr. Garvin's control. The great evening journal which Mr. Frederick Greenwood created has known many vicissitudes. It was a power under Mr. Greenwood, and again under Mr. John Morley, and again, of a very different sort, under Mr. Stead, whose caprices of mind and purpose, always vigorous and not always wise, led this journal along strange paths to strange ends. It has had other editors, no one of them, capable as they were, seeming to find a permanent foothold. But Mr. Astor saw that there was room for, and need of, a Conservative evening paper conducted on lines different from those of any existing journal, and he offered the Pall Mall to Mr. Garvin.

It is no light matter to edit a daily and weekly at the same time. But Mr. Garvin's power of work has no known limits, and he shouldered the double burden with a just confidence in himself. That he would be content to edit the Pall Mall in any spirit of routine or to imitate any of his predecessors, nobody supposed. Overnight the process of transformation began. To remodel any newspaper completely is 
a serious task, to be accomplished step by step. In the practical business of journalism Mr. Garvin shows the same qualities which have made him the great editor he is. He well knows that to preach the gospel you must have a pulpit to preach from, a platform from which you can reach the multitude. So he has set himself to make the Pall Mall a newspaper in the right sense of the word, as well as a journal of ideas and convictions. In the leader columns the revolution was instantaneous. Mr. Garvin's unsigned articles are signed in every line. He has in him that kind of intellectual energy which is neither rhetorical nor forensic but the outcome of fervent belief, religious in its intensity, kept in order by knowledge, with a scientific basis for his apostolic mission. 'The opportunity of saying at once what ought to be said instead of waiting a week is now his. He is eager to say it and the public is eager to hear ; none more so than journalists themselves, whether with him or against him. To both he is an inspiriting influence.

About Mr. Astor's conservatism there is no doubt, and his American countrymen owe him a debt for that; since, on the matters now at issue, the conservatism of England and the conservatism of the United States are twins. His principles and his interests may coincide; each a greater force for the help of the other. When Mr. Lloyd George's first Budget spread alarm among men who had something to lose, Mr. Astor acted in his usual decisive way. We were discussing at Hever the exit of capital from England to safer homes. Stories were current of fleeting millions. I asked Mr. Astor whether he thought them true.

"I know of one that is true. Within the last three 
months I have remitted to New York a million and a half sterling $(\$ 7,500,000)$, which but for $\mathrm{Mr}$. Lloyd George's Budget I should have invested here." "May I say so?"

"Repeat it to whom you will. I care not who knows it."

So there is a tribute from this expatriated American to the financial security of the country that once was his.

The truth is, Mr. Astor has remained, spite of his British naturalization, an American. Nobody could take him for anything else: in appearance, in manner, in speech. He has the American abruptness, quickness, decision. He has been in close contact with three civilizations, American, English, and Italian, but it is the American which has left its stamp on him; an ineffaceable hallmark. He is an American host, with that liking for precision and straight lines which is certainly not English. In earlier days the English thought him rather a martinet who arranged the days a little strictly. If that was ever so, it has long since worn off. They imagined a story that when a Royal Princess was staying with him at Cliveden who was unpunctual at dinner, he went in to dinner without her; no doubt the invention of some guest who was not royal and was late. In truth, there was no house in the kingdom where you disposed of your time more freely than at Cliveden. A choice was offered you but you chose for yourself, or did nothing if you preferred that. It is the same at Hever Castle. I have sometimes spent a Sunday alone with Mr. Astor at Cliveden. There is no better way of judging, and he is then at his best. His talk ranges wide. He touches life at many points, and neither the eye 
MR. WILLIAM WALDORF ASTOR 275 nor the hand, neither the judgment nor the intuition, is at fault.

His eldest son married an American, his daughter an Englishman. The scales were held even. The son was brought up as all Astors since the first have been brought up; to take life seriously. He was educated to the business of managing a vast estate. Again the American tradition, the Astor tradition, cherished and practised here in England exactly as in New York. He could not cast it off if he would, and most certainly he would not.

You may call mine an estimate of friendship if you like but, friendly or not, it is true as far as it goes. I have written of the man as I know him. He lives in England, but New York in its new development, in the movements of population, in the values and prospects of real estate, is as familiar to him as if New York were still his home. And his services to his native land are perhaps as great as if his nationality and citizenship were still American. 


\section{CHAPTER XXIV}

JAMES M'NEILL WHISTLER-ANECDOTES, ESTIMATES, FRIENDSHIPS

IONG since a literature has grown up about Whistler and there may seem no particular reason for adding to it. A legend also has grown up, as about all unusual men. But by dint of omitting all the well-known stories concerning him it may still be possible to say something. I knew him for many years, in many places, in many ways. We were friends till the inevitable end came. I have letters of his, mostly brief, always pungent, sometimes epistolary masterpieces, and his books which he gave me; books like none others.

I have a pencil drawing, also a gift: one of the most beautiful he ever did; a figure of a woman, nearly nude, wholly nude, indeed, but for a perfectly transparent veil of gauze; a cloud rather than a veil, through which the delicate, full contours of this modern goddess are visible, their values enhanced by the mere suggestion of mystery thrown about them. It is nothing to say that this is a poetic treatment of purely physical facts. They are not purely physical. The little drawing is a poem of exquisite loveliness. The figure is at full length, about eight inches high, the left arm outstretched; the fingers holding the drapery through which the outlines shape themselves; the right arm a little away from the body; the body poised on the right foot, solidly planted 
on the ground, if there be any ground; the left just ready to take flight. The whole aerial, unsubstantial ; the fabric of a dream, yet drawn with a precision and firmness as if for all eternity. And since, for all its purity of treatment, there is a hint of fleshly beauty and of temptation, it was probably drawn especially for what is left of this life before eternity begins. Signed twice over with the butterfly, and signed in every line and touch of the master. Even the frame is Whistler's; its expanse of white mount and narrow edging of white wood and black lines one more proof of his theory that the frame is part of the picture.

I knew Whistler long before his fame began, and long after. He was always the same Whistler. Of his own value and of his own work he never had any doubt. Popularity was never with him a measure of merit. Perhaps he never was so sure of himself as when he was in a minority of one. When he brought that unlucky action against Ruskin, ending in a verdict of a farthing damages, he was never for a moment disconcerted. I was in court with him, and when I held out my hand to him in sympathy with his defeat he grasped it warmly and cried out :

"I was sure you would see what a great triumph it is."

What could you say to that? I always thought his case badly handled. His lcading counsel, Mr. Serjeant Parry, was an able advocate in a commonplace cause but quite incapable of putting Whistler's view to the jury, which was quite incapable of scizing it if it had been put. The great painter had been grossly libelled by the great critic, yet the action ought never to have been brought. The machinery of British justice is ill adapted for judgments upon art. Ruskin was the spoiled child of critics: wilful, perverse, whimsi- 
cal, and dangerous because he was both brilliant and sincere. A great authority with the public, then and now; but ask the artists what they thought of him. One of the best of them, whom I think I had rather not name, said of him : "He is never right." Another applied to Ruskin what Thiers said of the Third Napoleon : "Une grande incapacité méconnue." But he was a rhetorician who captivated the public. What more could you ask?

It was at Whistler's house in Tite Street, Chelsea, that I first saw the woman whose beauty was, I suppose, more famous than any other of her time. I had gone there to breakfast; a twelve o'clock breakfast such as Whistler liked giving in those days, with such American delicacies as corn bread and buckwheat cakes to astonish the dull palates of his British guests. When the door into the parlour opened, this lady was sitting on a low chair in the corner by the fire, and the light of the fire shone on her face. A vision never to be forgotten; the colouring brilliant and at the same time delicate; the attitude all grace. There was a harmony and a contrast all in one; the harmony such as Whistler loved; the contrast such as it pleased her Maker to arrange, between softness and strength; the lines of the woman's full body flowing gently into each other, but the whole impression one of vital force. There was no one else in the room. As her renown, presently to be world-wide, had just dawned in London, I knew who it must be. We began to talk. When Whistler a moment later came in, he said: "Of course you and Mrs. Langtry know each other." That was all the introduction we ever had.

I supposed Whistler was going to do her portrait, but I cannot remember what it was like. 'The one which London admired next May in the Royal 
Academy came from a heavier brush than his and was signed Millais. But Mrs. Langtry was the despair of all the portrait painters. Other beautiful women have been, and still are. Whistler himself was of an uncompromising nature in the presence of beauty. The story of Lady Eden's portrait needs no retelling. The portrait of Miss Connie Gilchrist was not to the taste of that young lady's many admirers. It hung in the studio that morning. Whistler was not a man who asked for an opinion on his work or expected you to give it unasked, as many artists do. If they do not, for what was the institution of Show Sunday invented? But Mrs. Langtry, who even in those early days passed Acts of Parliament for her private use, took command of the situation :

"Oh, Mr. Whistler, what a lovely portrait! I have seen Connie Gilchrist only once but I'm sure it is hers. Nobody but you could have done it so beautifully."

As guests we could have no other opinion. As critics we might think it a flimsy piece of work, as Whistler in his heart probably did. But before this he had said :

"A work of art is complete when it expresses the idea in the mind of the artist."

He varied the formula but he held to his opinion and painted on it, though not always. Miss Connie Gilchrist with all her celebrity never, I think, forced her way into the never crowded ranks of the professional beauties, of whom Mrs. Langtry was the acknowledged queen. She passed early in life from the stage of the Gaiety Theatre to the ranks of the aristocracy, becoming Countess of Orkney in 1892. She is still living. What has happened to her portrait I know not. On the stage she had, before all things, 
la beauté $d u$ diable - that is, the beauty of youthhaving begun her career or become known to the public and to the gilded youth who then thronged that theatre, at fourteen.

I stayed on after the company had drifted away, and Whistler began at once with his explosive questions :

"Of course you knew Mrs. Langtry?"

"I had never seen her."

"Then you had never seen the loveliest thing that ever was. Don't tell me you don't think her perfect. It doesn't matter what you think. She is perfect. Her beauty is simply exquisite. But her manner is more exquisite still. She is kindness itself."

I was in no mood to dispute any of these propositions, though when I saw more of Mrs. Langtry later Whistler's account of her did not seem to me quite complete. But with or without Mrs. Langtry, Whistler's breakfasts were like none other ever given. You could not have a Whistler breakfast without Whistler. Certainly his conception of the duties of host was not a conventional conception. In social life, as in art, conventions were to him so many objects of contempt. He, too, like Mrs. Langtry, passed private Acts of Parliament for his private use. He was hospitable, kindly, but despotic. The Acts of Parliament were for our use, too; we were to obey them. None of us minded, only it was sometimes difficult to know when they were passed, and what they were, and when they were repealed, and when a new Act came into force. Whistler, from the head of his table, or at any other table, it mattered not which, laid down the law. His strident voice dominated all others.

In that he was like Hayward or Browning, both of whom, when they chose to assert themselves, could 
overpower the whole company. But both Hayward and Browning were men of the world and of society. Whistler was neither. He went much into the world and often into society. But he went where he liked; never for any lesser reason. The circle in which he moved was of his own creation. Hayward was selfmade but for forty years a great social force in the best London. He would raise his voice if he had a story to tell for which he wanted a gallery. Browning was content with those nearest him till he had a proposition in metaphysics or a theory of music to announce, and when that moment came it was useless to compete with him; nor did many men try; or not twice.

But Whistler's flashes and impulses of inspiration were continuous. The subject did not matter. It might be a dish which he had just been into the kitchen to superintend. It might be an outrageous lampoon on some one of those Enemies the making of whom he held to be a "Gentle Art"; an art embalmed in the title of his book. It might be a sentence of homage to Mrs. Langtry. In any of these cases or a hundred others he disdained privacy. He desired to give the world of his best, and desired that the world to be benefited should be as large as possible. He poured out the riches of his mind. Never, I should think, was there a man whose confidence in himself was so complete and so completely justified. He was a match for anybody. His power of retort was tremendous and multitudinous. For this man he had a rapicr thrust and for the next a bludgeon, and he would use one with just the same sense of artistic delight as the other. I am not sure that he ever met his match.

People used to pit Mr. Oscar Wilde against him, but Mr. Oscar Wilde went down before him as often as 
he tried to stand up to the master. Men whose wits were far inferior to Whistler's would bowl Wilde over with ease. Mr. Bernal Osborne did ; nay, for a long time Mr. Bernal Osborne made Wilde his butt, and Wilde had no defence. He had no courage. Bernal Osborne had no very wonderful intellectual equipment, though he was for a long time a distinguished figure in London society, both before and after his accomplished daughter married the late Duke of St. Albans. But Osborne had a dauntless soul. He did not care whom he attacked; nor was he an easy man to arouse, still less to put down. I cannot recollect that I ever saw him in collision with Whistler, but I have no doubt what the result would have been, for I have seen Whistler in many a duel with many a man of whom Osborne was not the equal, and I never knew Whistler to leave the field defeated. That is true of him in all the circumstances, and they are many, in which I have met him.

It has been said of Whistler, truly enough, that he was proud of the white plume in his black hair. But with his pride went, naturally, a certain sensitiveness. He wanted his little tuft of white treated with respect; as a flag. It was sacred; as the white flag was to the Comte de Chambord. Most people respected Whistler's wish, if not all. I went one day to a lunch given by a lady whom her friends set up as a rival to Mrs. Langtry. It was a large party. When the ladies went upstairs most of the men were bidden by their hostess to follow as soon as the first cigarette had been smoked. Whistler was not told; on the contrary, a man was asked to hold him in talk for ten minutes. Once in the drawing-room, the hostess produced a number of white feathers, one of which she fastened into each man's hair, in front, where Whistler 


\section{JAMES M'NEILL WHISTLER}

wore his. Then she marshalled her men in line, facing the door, and sent word to Whistler in the diningroom that he was staying a long time and she would like him to come up. He obeyed and when he opened the door of the drawing-room found himself confronted with a line of black-haired men, each decorated with a white plume in imitation of his own. His face turned red and then pale. He walked slowly past the line to the end where stood his hostess enjoying what she thought an innocent plaisanterie. But Whistler's expression had in it much more of tragedy than of comedy. "Ah, yes," he said, "very pretty, very pretty indeed. To not one of you will I ever speak again." With that he turned his back on his hostess and her guests, and marched out of the room, and downstairs, and out of the house. Yet his anger did not last.

This was the lady whom I once beheld conversing long in a drawing-room with Mr. Bernal Osborne. When they parted I said to him :

"You seem to admire Mrs. X."

"Yes, I do, and I should admire her still more if while she is talking to me she would not make eyes at the footman over my shoulder."

I repeated this to Whistler who replied instantly:

"Yes, very good, very good. But it was I who said it."

He made an extraordinary use of his imagination. It affected all his relations in life. It affected his views of art, quite naturally, but also his views of property in art, or in his own art. He held, in at least one case, that a picture he had painted and sold and been paid for was still his picture to do as he liked with. He said :

"How can an artist divest himself of his property 


\section{ANGLO-AMERICAN MEMORIES}

in his own offspring; a work into which he has put all his genius, all his art, all his personality; himself, in fact?"

And upon that he acted. I never doubted he was sincere. He could look at such a question from his own point of view and from no other. Whistler, like another eminent American, might well have said :

"The essence of any struggle for healthy liberty has always been and must always be to take from some one man or class of men the right to enjoy power, or wealth, or position, or immunity, which has not been earned by service to his or their fellows."

Sir William Eden, in Whistler's view, had not " earned" the picture of Lady Eden merely by paying for it. The right of property was inherent in the creator of the picture. But both these doctrines, which are complementary, are a little subversive of those on which society is founded.

Not less characteristic of Whistler is another incident which befell in my hearing at dinner. He told us the story after the ladies had left the table.

"I did not like to tell it while those lovely creatures were here for it is not to be repeated just yet, and though they are lovely, or perhaps because they are lovely, they will gossip."

He then explained that he had long wished to paint the portrait of Mr. Disraeli. After trying in vain to get an introduction he had obtained a letter from a great friend of the Prime Minister and gone down to Hughenden with it :

"It was not the season when the primroses were coming out, which Dizzy said he had never been able to see because politics kept him at that time in London. His saying that was one of the reasons which made me want to paint him. I was told that after 
luncheon would be a good time to catch him walking in the park. I had no great faith in my letter; at any rate, I was resolved to meet him face to face, and I found a back gate into the grounds near the house; slipped in and waited."

He went on to tell us at greater length than I can quote how at last the great man appeared, and how when Whistler approached him, letter in hand, he said:

"No, I want no letter, You are Whistler and I am glad to see you. I suppose you wish to paint my portrait."

There was a conversation which lasted many minutes, and ended by Disraeli assuring Whistler he could give him sittings but could not then fix the dates. They parted on the friendliest terms.

We all listened with delight. The artist was vivid, dramatic, picturesque, and gave us there and then a portrait of Disraeli and of his manner of speech and gesture that was lifelike. His narrative lasted altogether some twenty minutes and ended with a fresh caution to all of us to keep his secret, which we all promised.

It was a romance from beginning to end. Nobody had given him a letter to Disraeli. He had never met Disraeli. He had never been to Hughenden. 'There was no question of a portrait. Some time after, I asked him whether the sittings had begun. $\mathrm{He}$ laughed delightedly :

"Why, you don't mean to say you believed that story? But, of course, I saw you did at the time. It was just an experiment, my dear fellow. I thought I should like to see whether I could take you all in. I wonder whether I shouldn't do well to write a novel."

"Religion," said Daniel Webster, "has nothing to do with politics. There it makes men mad." 
And morals have nothing to do with art, and art was the only thing with which Whistler cared to have anything to do; and he had a set of art-morals as inflexible as those of the great men of the Renaissance who painted portraits of their mistresses and called them Madonnas. He chose to amuse himself at our expense. I wish I could be amused again in the same way. But there was only one Whistler and there will never be another. He was absolutely the same man in adversity, of which he had bitter experiences, and in prosperity, which came to him late and perhaps never with full hands. Never was he more imperious than when the world looked coldly on him; never more triumphant than in defeat and neglect. If people tell you that he was capricious, overbearing, self-centred, vain, you need not pay too much attention. Constancy and courage were the foundation of his character.

He came sometimes to a certain London club which was, and is, a rendezvous for men who bring to it exceptional gifts and who can talk. If it were permissible to mention names many of them would be recognized in America as readily as here. But, on the whole, Whistler had not his equal in this brilliant group. No other mind was so supple as his; none other had quite the same gift of spontaneity; none moved so quickly; none had so singular an originality. A retort came from him like a flash of lighting; often a growl of thunder following. He liked applause and got it in large measure. If it was denied him he was content with his own approval.

Whistler's quarrel with the Royal Academy was only one more illustration of the unfitness of that astonishing body to be the guardian of British art and artists. The only thing it guarded effectually was 
Philistinism in art; a duty in which it had the help of other institutions less well known but powerful in their way. It was not the Academy which made known Whistler's genius to the British public, nor any of the other art societies flourishing then and still in this British capital. But there came a time when his fame could hardly much longer be disputed. The Portrait of his mother hung in the Luxembourg, and the Paris Salon had done him the justice which Burlington House denied. Whistler had long since left London for Paris. The incident I am going to retell was described in a letter to $\mathcal{T}$ be $\mathcal{T}$ imes shortly after Whistler's death, and I then named the Royal Academy as the body which had sent the invitation. But the Secretary of the Royal Academy explained that there was no record of any such invitation, and he was quite certain none such had been sent. I must therefore presume that it came from some other English society, and I must regret having wrongly attributed it to the Royal Academy, and regret still more that the Royal Academy is not entitled to the credit.

I got a letter from him dated Brussels, which was a cry of victory. "Read the enclosed," he said. "At last they have owned up. They acknowledge they were wrong, they confess their sins, they appeal for help." The enclosure was a letter from the Secretary of one of these art-societies, with a circular announcing an exhibition of pictures, and to this, in handsome terms, they asked Whistler to contribute.

"You won't suppose for a moment," exclaimed Whistler, "that I shall send them anything of mine. Read my letter to them."

I read it with dismay. It was in his most belligerent vein; a letter of flouts and jecrs; reviling them for their old injustice, and taunting them with their 
present futile effort to put themselves right. I thought it unhappy and ill-judged. I wrote Whistler begging him not to send it. They had offered him honourable amends for the past. To reject it with insult would only be to put himself instead of them in the wrong. His answer came by telegraph.

"So sorry you too have gone over to the enemy."

From that day to the day of his death I never again met Whistler nor heard from him. The book was closed. It was impossible to reproach him; impossible to forget him or his friendship; you could only regret. You accepted him joyfully as he was or not at all; with all his caprices; with a certain feminine irresponsibility, or perhaps instability, of nature from which he was never free. And if once you had an affection for him the affection remained, as the admiration of the world for the great artist remains and will ever remain. 


\section{CHAPTER XXV}

\section{SIR WILLIAM SCHWENCK GILBERT}

THE man who has amused them is the man 1 to whom people are grateful, and the papers overflow with eulogies on Sir W. S. Gilbert. The cable says the American papers do likewise. Not only eulogies but anecdotes abound. It is as if every story, every repartee, every pun or quip of his had been stored up as it appeared, and now they fill columns. It may not be possible to quote one saying of his which has not been quoted during these last few days, and especially the day after his death, which only proves that the obituary pigeonhole had long since been well stuffed. I will try to repeat nothing that has been in print.

Not much remains for me, therefore, except to give you a personal impression and perhaps one or two personal incidents which have escaped the general chronicler because they were personal to Gilbert and to me. I do not mean to imply that between us there was anything like a personal intimacy. There never was. Twice, at least, we stood upon the verge of a personal quarrel, the last time only a few weeks ago. My acquaintance with him was a social or club acquaintance. The truth is, he had a warlike nature. His panegyrists lay stress on the kindliness of his satire in his plays and operas. That is true enough, and it is true also that he was full of kindliness in his relations with his own world. 
But it is true also that he had an arbitrary temper. He liked to domineer. He liked his own way better than yours or mine. And I should think he got it as often as most men. Ask the members of the theatre companies whom he stage-managed. He was a tyrant at rehearsals, and I will only add that it would be better for the English stage if more English authors had a knowledge and authority equal to his.

When I said he was warlike I might have said military. He looked a cavalry colonel. He was tall, square-shouldered, well-set-up, with a square forehead, a piercing eye, sometimes with an angry light in it; a red-bronze face, a well-trimmed moustache, grey in later years, and an air of command. Indeed, he had meant to be a soldier, a gunner, as they say here, meaning an artillery officer, but the examination was put off till he was over age and he had to content himself with militia service and the rank of captain in the Royal Aberdeenshire Highlanders, retiring after fifteen years' service as brevet-major.

But he never really retired. He only transferred to civil life his habit of giving orders; not on the stage only. When he had made a fortune, a large one, and become a country gentleman and taken his seat on the Board of Middlesex Magistrates, he issued orders to his brother Justices of the Peace with a severe politeness which disguised the form but left the substance. He was proud, rightly enough, of the position he had won and of his influence on the bench. I should despair of explaining to American readers the position and greatness of the English Justice of the Peace, known to the discontented and unsuccessful aspirants to that place as "The Great Unpaid "; a phrase which might come from Dickens, and perhaps did, but I do not know Dickens. Nothing 
could be more characteristic than the remark of Mr. Carlyon, chairman of the Wealdstone Petty Sessions. He thought Gilbert so eminent a colleague that he proposed a resolution of sympathy with his widow, although Sir William had never been chairman, and it had never been the custom to give official expression to their official sorrow for a magistrate who had not held that exalted rank. Justices of the Peace are appointed justices by no less a personage than the Lord High Chancellor, whom the Radicals have lately attacked in Parliament because he would not recognize party services as a title to these judicial places.

Gilbert liked to refer to his magistracy and to describe cases with which he had dealt. He desired us all to appreciate his position and authority. A friend who enlivens his life by "pulling the leg" of friends who will let him has been known to condole solemnly with Gilbert on his magisterial inferiority and his inability to make his wishes supreme on the bench.

"I am sure, Sir William, the interests of justice would be much better served if your colleagues did not overrule you so often."

The taunt stung, and the great humorist of the stage had not humour enough to cover his own case, but resented the suggestion and insisted that his judicial opinions were respected and followed. Said the leg-puller :

"Once in each three months I can get this same rise out of Gilbert. No man is so easy to draw."

On all subjects Gilbert took himself seriously. It was only his friends and the public who were proper subjects of jest. His knowledge of the stage was so vast and his success as a dramatist so immense that he could understand no trifling with this subject or with himself as dramatic author. Whether he 


\section{ANGLO-AMERICAN MEMORIES}

ever understood how much of his success was due to his association with Sir Arthur Sullivan and $\mathrm{Mr}$. D'Oyly Carte may be doubted. He valued himself at least as much on the dramatic work which was exclusively his own as on the "books" which Sullivan put to music and D'Oyly Carte financed. The public did not always agree with him, nor the critics, but he never yielded to the public or the critics. Criticism he resented. I once heard an eminent dramatist, happily still living, remark that the critics know nothing of the stage-" absolutely nothing." I suspect Gilbert thought so; with reference to plays of his which they disapproved.

It seemed that he sought for a personal motive in any criticism that was not to his mind. Seemed ? Nay, he did. There came a letter from him some two months ago saying that my attack on him in the volume of Anglo-American Memories he had been reading could have been inspired only by personal animosity, and he wished to know at what I had taken offence. I could only answer that there was not, so far as I knew, an allusion to him of any kind in the book. He retorted that I had spoken of the jingle about "Howells and James young men," of which I said the music-hall was the proper home. "You must know," continued Gilbert, "that the verse is from my opera Patience, and the reference to the music-hall is insulting." I was obliged, though at the risk of giving further offence, to explain that I did not know it, and that nothing could be further from my mind than to affront a writer for whom I had always felt and expressed a true admiration. This he accepted, though not without a suggestion that I ought to have known the line was his. So finally we shook hands again and the sky cleared, 
and I am glad now to remember that it did. Not once could it have occurred to him that while he was complaining of my music-hall remark a one-act piece of his was at that moment being played at the Coliseum in London, the music-hall for which it was written.

Once before he had been angry because I quoted in The Tribune an epigram of his upon New York. He had just returned from America and his gibe at Manhattan, bitter but quite just at that time, was flung broadcast about London. I heard it, as others heard it, not from him, yet he thought the repetition of it in print a violation of confidence and resented it, and it was long before his wrath was appeased. He had, in truth, a feminine element in him, and the only point of view he could take was the personal view. But he is gone and I will not again print what he then said. If I write with some freedom about him it is because I think that not otherwise can any right impression of him be given, and because I think he must on the whole gain by a free account of his character and his way of life.

His convictions of stage discipline, and even the maxims of war on which some of them seemed to be founded, were applied with equal rigour to the training of actresses in whom he perceived the sceds of art. One of them was Miss Lily Hanbury, who had natural gifts which in Gilbert's hands bccame artificial. The other was no less a person than Miss Julia Neilson. At the house of a friend in South Kensington, Mr. Heseltine, a lover of all art, with many beautiful possessions, I met now and then both Miss Julia Neilson and Gilbert, and from both Miss Neilson and Miss Hanbury I heard interesting accounts of the tuition he bestowed on each. He was not content 


\section{ANGLO-AMERICAN MEMORIES}

to rely on nature or on natural aptitudes. He had Procrustean rules of stage training to which all natural gifts must be made to bend. So many steps to a particular spot; such a gesture to express such an emotion; the arms to be moved in accord with a settled theory of plastic effect; the tones of the voice to be such as the master thought most likely to come over the footlights; and so on.

If in Miss Julia Neilson's mature methods there be a suspicion of anything rigid or arbitrary, it may be traced to these iron-bound laws laid down for and enforced upon her by Gilbert in the days of her girlhood. She was then, I think, not more than eighteen; with an original beauty of which the copy may now be seen in her daughter, Miss Neilson-Terry, the newest and perhaps strongest of debutantes, playing Viola in Twelfth Night at seventeen with a brilliant self-possession and ease of movement in her boy costume. In her case there is no Gilbert to control her individual impulses, and it is interesting to see how the daughter wanders at will in the Duke's Illyrian palace, or as Rosalind in the Forest of Arden. An unconquered freedom hers, if ever there were one. In his dealing with the formed artists to whom he entrusted his stage characters Gilbert was not less absolute. For the first night or the three-hundredth night his will was law, and there were penalties for a departure from it if ever any actor or actress proved hardy enough to vary by a hair's-breadth the instructions he imposed.

Certainly Gilbert's influence on the stage was, in respect of morals, altogether good. He himself said he had never cared to transgress the unwritten law of English life which would keep the theatres open to the English girl; as the French theatres 
are not to the French girl. He added that he had never found the limitations a restriction upon his dramatic work or aims. But he went beyond that. A story will show you how far.

There was during the period of his best operas an English singer who both as singer and actress was at least the equal of the best who won fame at the Savoy. Musical critics thought her voice and training both of a high order. I asked Gilbert why she had never sung for him. He answered :

"Because my companies consist of ladies and gentlemen. The singer you name was for a short time with us during rehearsals, but she was impossible."

And he explained why she was impossible. The anecdote is not suitable for print but to Gilbert's mind it was conclusive. He drew a broad line between the Savoy operas and musical comedy or what was in those days known as burlesque. He would tolerate no licence on or off the stage. He was a more implacable censor than the Lord Chamberlain; and over the Lord Chamberlain or his reader, Mr. Redford, he had this advantage: that whereas Mr. Redford knew only what was in the manuscript submitted to him, Gilbert was his own producer of plays and no look or gesture or innuendo escaped him. While he lived and while his operas at the Savoy held the town, and while his plays were an attraction to a more select public, his influence was a very potent one. There was a period of a quarter of a century during which it was vital, and was always a purifying influence, and always tended to bring literature and dramatic art into closer relations. That is not all but with that we may well be content, as with his seventy-three years of completed achievement and with his death in a generous effort to save a younger life. 


\section{CHAPTER XXVI}

MLLE. AIMÉE DESCLÉE-HER ART-HER LET'TERS-HER LIFE

R EADING lately proofs of some of these Memories Desclée. Of her I undertook to say something. It was a promise of which I needed no reminding, for if there is anything of which I have a vivid memory it is of her and her acting. In America she was unknown. She never crossed the Atlantic. In London she was not unknown, for she played here during one season at the Princess's Theatre, but she is forgotten. Often as we moralize on the oblivion which is the early fate of almost all great actors, this is the most melancholy of all. For Desclée was the greatest of emotional actresses, and nothing is so transitory as an emotion except the expression of it on the stage. M. Alexandre Dumas, fils, with whom as an author her fame as an actress is for ever bound up, says of Desclée without any qualification that in her art she was the first. He adds:

"It was for us to write Le Misantbrope; she would have been Célimène. It was for us to write Romeo; she would have been Juliet. We have done only what we could; she has done more than she ought, and thus it is that she killed herself."

I saw Aimée Desclée often in Paris at the Gymnase, and often in London at the Princess's. In neither city was she one of that glittering company of artists 
whose celebrity lay outside of her art. I do not mean that she led a life of order; she did not; but that the splendour of a lawless existence had no attraction for her. The truth about the matter is to be found in that astonishing book, Lettres de Aimée Desclée à Fanfan, published in Paris in 1895 ; a human document if ever there were one. But it is one which ought never to have seen the light of day. The editor of it is M. Paul Duplan, a name of no great authority in literature. But the true author of it was M. Alexandre Dumas the younger. He inspired it, and for it he must be held responsible. He wanted at all costs a record of the career, of the genius, of the brilliant personality which he had enlisted in the service of his drama; of the actress for whom he wrote three of his best plays, and to whom he had been indebted for an interpretation of a kind which no other actress could have given him. He might well have written her life or paid an adequate tribute to the actress. He preferred instead to publish, or to sanction the publishing, it is the same thing, of her letters to her lover. That the public might be sure to remember the actress and the plays she had acted, he flung them the woman.

It is not known who Fanfan was. He has earned a sort of anonymous immortality and the name which Desclée gave him will be remembered by her letters. All that can be said about him is that he was an officer of the French army.

But to M. Paul Duplan Fanfan was known. They were kinsmen and friends. He too died young. His portrait is by the side of Desclée's in M. Duplan's study.

"There he is, as I knew him, with his happy, grave, good look; in uniform, his chest starred with 
decorations. A tall young fellow, carrying jauntily, intelligently, a fine soldier's name; well taught, a man of letters, with a marked elegance of manner, an expressive face, a soldier's face, made more soldierly by a long moustache which his mistress, the gamine or mome as he calls her, used to love to lift, 'to see what there was underneath, and to find what she was looking for, white teeth and kisses." ",

And that seems to be all we are likely to know of Fanfan, save what Desclée herself tells us in her letters. While the soul of the woman who loved him was stripped naked, his identity was carefully concealed. I would print his name if I knew it, but I do not. I have often asked. Nobody seemed to know, unusual as it is in Paris for secrets of that kind to remain secrets. It is fair to say that the French standard of honour is on this one point less rigid or less universal than in England or in America. A French lover kisses and tells; though Fanfan perhaps did not. The certainty or the possibility that he will tell ought to put virtue, and also vice, on its guard. It is not quite clear that it does. A French writer like Dumas, of the first order as a writer of plays, betrays the confidence a woman gives him when she trusts him with letters, her own and another's.

The public which thinks itself the gainer by this looseness of honour may be disposed to condone the offence. M. de Guibert must have been a consenting party to the printing of the letters of Mlle. de Lespinasse, incomparable letters as they are, yet, like those of Desclée, letters all passion. But since the letters of Mlle. de Lespinasse were written a century and a half ago and the letters of Desclée only yesterday, the offence in this last case seems less 
pardonable. It is not certain how far M. de Guibert was really in love with Mlle. de Lespinasse, or whether he returned her passion. The inference you draw from Desclée's letters is that Fanfan really did care for her, though for no very long time, and of the nature of the relations between them there is no doubt.

A worse thing has to be said of Dumas. He publishes letters from which you cannot but suppose, nor doubt you are meant to suppose, that at one time Desclée was in love with him. Her love for him he first rejects, then proclaims. $\mathrm{He}$ is not a man of too many scruples. We are allowed to understand that many other actresses have flung themselves at his head, vainly. With his abstention, morals have nothing to do. But he assures us that, as between author and actress, he considers such relations inconvenient and compromising; a business mistake, in fact. His relations with other women he blazoned abroad. Not a few of his scenes of love in his plays are understood to be autobiographical; especially if with women of fashion and title. One such woman asked him :

"Mais où donc avez-vous étudié toutes ces femmeslà ? Chez elles?"

"Non, madame, chez moi."

Against which may be set the pathetic saying of Desclée, from out her life of hardship and poverty and truth to art:

"Mon amour n'a jamais été un amour vénal; et la preuve, c'est mon cinquième étage et mon piano de location."

Hers had indeed been a life of struggle. Twice she had appealed to Paris, and twice in vain. Paris was at that time busy in burning incense before 
Mlle. Rose Chéri. If the public had eyes for any other they looked to the Théâtre Français, where Madeleine Brohan was still in the full bloom of her talent; where Croizette had established the position which Sarah Bernhardt was just challenging; where there was a whole group of artists we shall never see again. It was after these two failures that Dumas one night found Desclée acting in Brussels, and went round to her box to tell her that gifts like hers could bring her the fame that was her due in Paris only.

"No," said Desclée, "I have shaken the dust of Paris off my feet. I will never go back."

Dumas pleaded with her, promised to use his influence with Montigny at the Gymnase, promised her a play, promised her success. She hesitated long, finally yielded, went back to Paris, and again failed. It was not till she created Meilhac's Froufrou that she finally conquered the stubborn public of the City of Light.

In truth, Desclée had much against her in that long battle, and her best self was probably never revealed till success came. She needed the inspiration which only victory can give. I never saw her till after the contest was over between them. She was, at first sight, disappointing. There stepped out from the wings a plain little woman, none too well dressed, without much symmetry of figure or grace of movement. If you looked for beauty you hardly found it except in the beauty of brown eyes and a broad, low, Greek forehead. What you saw was almost insignificant, but what you felt you had never felt before, unless perchance you had seen Rachel. Different as the two were, they had this in common, the power of taking possession of an audience without a word spoken. Nobody has yet found the word 


\section{MLLE. AIMÉE DESCLÉE}

or phrase which really describes or defines this power. You may say it is magnetic, or sympathetic, or hypnotic, but that does not carry us far. What Rachel did, what Desclée did, and what no other actress I have seen could do, was to create a communion of souls between herself and the men and women who were before her. Desclée's was a soul of fire. By some process she herself could not make clear, the fire passed from hers to yours.

In such a part as the Princesse Georges the first words of the piece are electric, but before they were uttered the spark had found its way from her to you. The entrée en scène is, as Dumas wrote it, masterly, abrupt, rapid, empoignant, but as Desclée acted it the lightning is playing about the house while the first sentence remains unspoken.

Severine has been rendered by many an actress since, including Sarah Bernhardt herself. But when you had seen Desclée in it the piece became another piece with anybody else. In technique, in range, in much else, Sarah was superior to Desclée. But in temperament Desclée stood alone. She had passion and the power of expressing passion in a supreme degree. It was not men only who felt it. I once sat next a lady who saw Desclée as the Princesse Georges for the first time. This lady had, in fact, never seen her in anything. As the curtain went down on the first act she said :

"I have never had an experience like this. When you told me what I was to expect I thought you must be in love with Desclée. But what you told me was nothing to what I feel."

Then a pause; then :

"Whether you are in love with Desclée or not, I am. No man ever loved like that. No passion I 
have known or felt in any man or in myself is like Desclée's."

It was not, therefore, sexual, or not mainly so. It was a passion of the soul; not intellectual first of all, nor was the rendering of it an effort with which the mind had anything to do ; nor did it depend on technique, or even on art. It was felt. It was passion and nothing else. The impression left on you was not that Desclée was trying to open her soul to you, but that she was trying to hide it ; trying to suppress and moderate all this tumult of feeling. She never overstepped the line. There was no extravagance of gesture nor distortion of the face. This was simply a woman in whom passion blazed and burned; who was in agony; who could not control it; who would not have told you of it if she could have helped it. And all the time there were unplumbed depths of emotion of which you were allowed to know nothing.

Yet with all this, Desclée was too great an artist to be this and nothing more. In Froufrou and in the Princesse Georges and in the Visite de Noces she touched every note. While she played Froufrou she was Froufrou, "that pretty little Parisian soul, born in laughter and vanishing in tears." Everybody knows the scene between the two sisters at the end of the third act. I have seen it played by Desclée and by Sarah Bernhardt. It is one of those whirlwind scenes in which Sarah is supposed to be at her best, and perhaps is. She knew she had memories of Desclée to contend against, and played it accordingly. But Desclée had played it with a concentrated rage of jealous intensity to which no rival ever attained.

Still more marked was the difference between them in the first scene of the fourth act, after Froufrou has fled with her lover to Venice. They are break- 
fasting together in the hotel restaurant, and the lover is called away, as they both know, by a message from the husband; for the comedy has become a tragedy and nears its end. Sarah does not seem to mind very much. She looks about her as if bored by her solitude, and her first remark is uttered carelessly in a tone of intellectual detachment as if it concerned some one else. Hers is, in fact, an intellectual appreciation and nothing else. There is no appeal to sentiment, no sign of deep feeling. She is cool, speculative, almost indifferent. But Desclée sat there alone, in torment, her head resting on her hand, dejection in every line of her figure, and a world of pathos in her eyes. The words of which Sarah made so light came from Desclée's lips one by one like so many sobs:

"Une heure de colc̀re et voilà où j'en suis."

The smooth tones - passion-laden, vibrating, poignant, remorseful, as if only then had the folly of her flight and the wreck of her life become visible to her-stirred a passion of pity, as they were meant to, in all hearts. For Desclée was an actress who could act only what she felt at the moment. To have felt it once and to repeat the outward signs of it ever after was not to her a possible method of producing an effect.

In one of the notes-they are really essays and generally very personal-which Dumas appended to many of his plays in the Edition des Comédiens, he tells, or partly tells, a rehearsal story which illumines both him and Desclée. 'The rchearsal was of Une $V$ isite de Noces, which Dumas had written for her. It was characteristic of him that he expected an actress to rehearse her part with the same complete surrender of herself as if before an audience. $\mathrm{He}$ 


\section{ANGLO-AMERICAN MEMORIES}

was not content with what he himself calls Desclée's marvellous intuition and her profound knowledge of her art. He must have for the service of his play not only the comédienne but the woman; and into every critical moment of her acting the woman must put her soul. With the selfish coolness in which Dumas had no superior, he remarks that he knew very well what it cost her; not only a great expenditure of her forces mais un ébranlement pbysiologique. But there was a moment when he wanted, and would have, a certain cry which meant to her complete exhaustion for the moment. She shrank from it. "You shall have it when I act ; don't ask for it now." He insisted, and finally wrung it from her, and with the last ounce of strength she had left she said to him :

"Tenez, le voilà votre cri, et vous savez bien que cela me déchire les entrailles!"

Dumas softens the sentence a little but this is the authentic text. He admits that she added: "You will kill me," and that he replied:

"What does that matter if the play succeeds?"

But though these inexorable demands may have hurried on her death, I don't suppose Dumas was primarily responsible for the catastrophe. Nor is he, I will admit, without some sort of pretext for publishing the letters. He tells us that two or three days before her death Desclée sent him back all his letters to her, and also the letters by her written to "l'inconnu de Naples," saying :

"Take this correspondence which was restored to me when I asked for it. If I do not die you will return it to me; if I die, read it and do with it what you think it right to do."

None the less is the step a long one between Desclée's 


\section{MLLE. AIMÉE DESCLÉE}

trustful appeal to Dumas, and the use he makes of the discretion left to him. He may well enough have said that the letters were too precious to be burnt. You will search far before you find anything like them. Desclée had the gift of expression by words as well as by acting. If she had not much literature she had that kind of genius to which literature is only the handmaid. She never seems to seek for a phrase, but the phrase comes. She is bent on nothing but the revelation to her lover of her feelings, her thoughts, herself. She writes with absolute freedom, both to Fanfan and to Dumas. She writes, at times, on subjects not usually discussed even between lovers. But with her freedom goes a delicacy of nature which would serve as a veil for the coarseness, if coarseness there were. This delicacy she never loses, even amid excesses which are deplorable; the overflow, as she calls it, of her primitive nature. At times, her art seems to her a mere hypocrisy; un métier de saltimbanque.

"With a conviction which is artificial, declaiming certain things of which you believe not a wordlying, in a word; deceiving the eyes and ears of a more or less considerable quantity of people in order to amuse them for a few hours."

That is what she says of acting, in her desperate mood. The letter is to Dumas, and Dumas publishes many letters from her to him dealing more or less with questions of art, yet in which the artist too often leaves the stage and the woman appears. The great dramatist, for great he is, printed in one form or another many letters which a right feeling would have wholly suppressed; and they appear in many editions. I do not know that we need think the worse of Desclée; it is Dumas whose name is blackened by these treacherics. 
M. Paul Duplan's volume, Lettres de Aimée Desclée a Fanfan, appeared in 1895 . But Desclée died in I873, and was already half-forgotten. The book had no success. It never so much as went to a second edition. During these fifteen last years I have sent many copies of it at intervals to many friends, all of the first edition, and it is still in print. All I can say is that the impression made by her letters is very much the impression made by her acting. In her own life, as in the women she impersonated on the stage, she suffered much, loved much, sinned much. Her own confessions are the evidence against her, but when you have read them all and mourned over them, she remains a woman whose real nature was true.

And true is the word I have heard Mme. Sarah Bernhardt use to describe Desclée's acting, and in Sarah's mouth perhaps no other word means so much, or conveys a eulogy so high. If you have everything else in acting, or in any art, and though you speak with the tongues of men and of angels and have not truth, you are become as sounding brass or a tinkling cymbal. Whereas, if you have truth in the true sense, it seems to matter little what else you have, or have not.

When Mlle. Aimée Desclée returned from Brussels to Paris, or rather when she appeared in Froufrou, she was twenty-nine years of age. She died at thirtythree of a cruel malady which made her last few months one long agony. Into these four years, from I 869 to 1873 , she crowded the triumphs of a lifetime. To win them she wore herself out, and she won them almost against her own wish. Her longing was for repose, a convent, or no matter what. Yet into the mimic life of the stage she put her whole soul; 
her strength, her passion, her life. I use these words often but there are no others. She knew well it was a slow suicide. In the midst of her dazzling success as the Princesse Georges her prayer for a retreat and rest is heard again :

"But, mon Dieu, why am I not happy or even content? Shall I never be that? I make no complaint. How many women in my place would thank Heaven! The house full, each night flowers and triumphs enough to satiate tous les minotaures des théatres. Yet for all that I care nothing. It all comes to this, that I shall end beneath a nun's cap. I don't wish to kill myself but I would gladly die. At the convent I shall live in an ecstasy. I shall adore my Christ, and $\mathrm{He}$ perhaps will give me back what I give to Him. There only shall I at last be content with my lot; that perhaps is my true vocation. Still, I struggle on. Nobody cares that I should stay where I am. My disappearance will at least make a few people, a few women, happy. A place vacant. Whose turn is it ?"

That is the voice of a woman who had all Paris at her feet, the greatest dramatist of his time to write plays for her, the most critical public in the world crowning her with laurels; her fame world-wide. Whatever she might say at times, she loved her art. But the disease which was to kill her had already laid hands upon her; and in the bitterness of her reproaches you hear the cry of unendurable pain. From that time on her life was a martyrdom and death came as a deliverance. 


\title{
CHAP'TER XXVII
}

\section{SIR HENRY IRVING}

\author{
I \\ THE SOCIAL SIDE-CRITICISM AND FINANCE
}

I SAW much of Irving, first and last, and in many ways. He was to be met at many houses and his social gifts were remarkable. He had in private the fascination he had on the stage. His manner had a charm alike for men and women; and many women were devoted to him. The word which best describes his manner is not kindly or even attaching, the word Matthew Arnold and Froude loved to use, but affectionate. And his manner was affectionate because his nature was affectionate. He made of his hospitality something between a passion and a fine art. Who has not heard of the suppers at the Beefsteak Rooms in the Lyceum; which are not to be confounded with the Beefsteak Club, a wholly different matter. On Sundays the suppers became dinners. I have many memories of both. They were often what is called brilliant, and men and women of great position were there. But whoever was there it was Irving who was the central figure. In a patrician company the host was the most patrician of all. In all companies he had distinction, and as a host he had most distinction of all.

If you went to his rooms in Grafton Street it was the same. He met you with a welcome which was both friendly and beautiful. If he dined with you 
your dinner was sure to go off well. He interpreted his obligations as a guest largely, and felt it his duty to regard the dullest woman as delightful. If he was bored nobody ever found it out. If you knew his ways, or his wishes, you were always prepared to spend the greater part of the night with him, or that he should spend it with you. He would always offer to take leave when others went but what he really liked was to stay on, with one or two others, till three or four in the morning or later. Then he talked with an openness and a magic of speech that were all his own. $\mathrm{He}$ had a gift of epigram. Sentences came carelessly from his lips, in polished phrasing, quite perfect in form and, when need was, penetrating and sometimes deadly. But he was as a rule amiable, charitable to all, indifferent to enmities. He liked to talk of his art. If you asked him he would talk of himself and of his past; that long period of failure and privation which tempered the steel there was in him.

The supper which Irving gave to celebrate the hundredth night of $\mathcal{T}$ be Merchant of Venice was perhaps the most memorable of all. It was a great and distinguished company which assembled on the stage of the Lyceum. Lord Houghton was to make, in the name of the guests. and of the public, the speech of congratulation to Irving on his Shylock, which by common consent ranked among his best creations, and on the run of the beautifully staged piece. Lord Houghton at that time was still an important figure in the world of London, spite of his occasional eccentricities and uncertainties and spite of the general decay of his poetic reputation. He was, at any rate, a man of letters and he had a conspicuous place in society. He still gave breakfasts and perhaps was seen to more advantage at those early hours than later in 
the day. The Stanley incident, which had points of likeness to the one I am going to relate, had not then occurred. The outburst in the presence of the Prince of Wales had not occurred. He seemed a very suitable person to accomplish handsomely if not brilliantly the duty assigned to him at this supper.

But when Lord Houghton rose to make his speech, the unexpected happened. Instead of the eulogy for which we all looked there came a bitter criticism, and something more than criticism. The speech was a lampoon. He ridiculed Irving and his Shylock. He ridiculed the production of the play. Irving's conception of Shylock, his acting, his stage management, all came in for a share of Lord Houghton's invective. He was a guest and he disparaged his host. He was the mouthpiece of this company of Irving's friends and admirers, and he spoke as an enemy to whom Irving's genius was hateful. He came to bless and he remained to curse.

Now Irving, of course, had prepared a fitting reply to the speech of compliment he supposed Lord Houghton would make. He had to suppress the whole of it and reply to a harangue of a wholly different kind. Irving was known as a good speaker but those who disliked him used to say he could only deliver discourses written out beforehand and memorized. His friends knew better, but nobody had seen him put to such a test as this and curiosity was keen when he rose. But you had only to look at him to see that he was master of the situation. He was smiling. His manner was the perfection of courtesy. His tones were smooth. I will quote, of course from memory, a sentence or two :

"I cannot thank you enough, Lord Houghton, for the speech you have delivered. I am grateful to you for coming here to testify by your presence, if not by 
your words, to your appreciation of the effort $I$ and my associates have made to do what justice we can to $T$ be Merchant of Venice. I am grateful to you for the advice you have given me about the acting of Shylock. I should have been more grateful still had you given it earlier, so that I might have profited by it, so that my audiences might have profited by it, so that Shylock might have been presented to the public not according to my unaided conception of the part, but with the help of your views of his true nature and your ripe experience of the stage to eke out my imperfect knowledge. If you would have come to the rehearsals, think what we should have learned! Nay, dare I suggest that your appearance on the stage would have supplied for this theatre a sensation it never had before?"

By this time we were all cheering, sentence by sentence. Irving went on to ask Lord Houghton for specific instructions. Would he prefer that Irving should come on with three hats? Would it be right he should carry a bag of ducats? Ought the ducats to be heard jingling, "to help the hurt that honour feels?" Did he think it would improve matters if he exchanged parts with Portia? And so on, all with a light touch, all in the spirit of banter, all goodhumoured, but altogether a stinging rebuke to Lord Houghton. The supper resolved itself into two parties. One consisted of Lord Houghton. The other included Irving and every one else present. Lord Houghton moved restlessly in his chair. He was red with anger, but he had met his master and knew it and sat silent. There are few moments in Irving's career which his friends recall with greater delight; few in which the fine qualities of the man showed themselves with more decision. 


\section{ANGLO-AMERICAN MEMORIES}

To the question of criticism and its effect upon the actor there is, of course, a financial side when the actor is the owner or lessee of his theatre. Criticism may or may not be felt in his dressing-room but it is sure to be felt in the box-office. A theatre is a commercial enterprise. If it is to live it must pay and in order to pay the actors and actresses, or some of them, must attract the public. Depreciate the actor and you reduce the receipts, and if you reduce them below the living wage you close the theatre and send the performers out into an unappreciative, or too appreciative world. All this is obvious, yet it has to be restated as often as you estimate the influence of criticism on the actor.

In Irving's case many other things than criticism conspired to bring about failure at the end ; for failure it was. The management of the Lyceum was lavish. It was so lavish that purely fanciful stories of the sums invested in the production of particular plays were current. They ran as high as $£_{2} 5,000$. Irvingsaid to me :

"You have seen that $T$ be Merchant of Venice cost me $f 20,000$ ?"

"Yes; that is what some of the papers say."

"Well, I will not tell you what The Merchant of $V$ enice cost for I do not yet know. These gentlemen of your profession know a good deal more than I do. But I will tell you that the highest sum the production of any play has ever cost me is less than $\oint_{0} 7000$. If I had spent what the papers say, I should have been in the Bankruptcy Court long before this."

The expense was, in any case, far too great; and it was supplemented by other expenses arising not out of business necessities, real or supposed, but out of Irving's uncalculating kindness of nature. He had a 
pension list quite as much out of proportion to the deserts of his pensioners as that of the United States is to the services actually rendered in war by many of its countless beneficiaries. No man ever found more difficulty in saying no to a suitor. As manager of the Lyceum Theatre he had to dismiss many an actor and actress whom he found unsuited to the work he wanted done. Other managers do the same thing constantly. They must do it. But when it was discovered that Irving had given some of these ladies and gentlemen a continuing allowance, other ladies and gentlemen applied for allowances. So quick and wide were his sympathies that he presently found himself paying salaries, or half salaries, to a great number of persons from whom he got nothing in return. That was not business. It meant bankruptcy.

When I last saw him in New York, as he was sailing for England, he told me he had had a wonderful season. He had been in what he still called "The States" from autumn to spring, playing throughout to good business. He said :

"America is the place to make money; first, last, and all the time. Yours is a generous public; generous in applause, generous in support. I am taking $£ 30,000$ home with me."

What became of it, and why at the end was he forced by need of money to go on acting when he ought to have rested ? That, and that only, caused his death.

During this last hour in New York he looked tired but in great spirits. There was always in his face something of the ascetic; of the great ccclesiastic. It was stamped with lines of thought and of other hard work. He had always worked. If his had been a life of splendour, that was because it had also been 


\section{I 4 ANGLO-AMERICAN MEMORIES}

a life of toil. He and Sarah Bernhardt were alike in that and in their genius for splendid squandering. He did the work of three men; of the actor, of the producer, and of the manager. He shouldered responsibilities lightly, but never shirked them. His face was the record of a great career and the outward expression of a great soul.

II

THE ARTIST, THE MAN, AND SOME OF THE PARTS BOTH PLAYED

Whoever knew Irving at all well must be in some doubt whether his memories of Irving the artist or of Irving the man have left the deeper impression. In truth they are inextricably intertwined. You cannot separate them, nor could his audiences in the theatre, and it is this intimate union between the qualities of the actor and his personal qualities which accounts for no small part of Irving's immense and permanent fame. When you try to distinguish between the two you find yourself sometimes on one side of the border line and sometimes on the other; and you do not always know when you have crossed it. And perhaps it does not much matter. In what I have to say of Irving I shall let the impressions take care of themselves. There was a real Irving who was just as real when he was playing a part as when you met him in private life.

All this was evident in his acting of such a part as Mephistopheles in Faust. There are in the impersonation of every great rôle certain moments, seldom very many, which reveal to you as by flashes of lightning 
the genius of the actor, or his want of it, or his fitness or unfitness for that particular part. Such a moment, one of his happiest, was that when Irving, all in the conventional red and red cock's feather of the conventional Mephistopheles, floated-there is no other word for it-down the stage to the footlights and breathed out into space in hardly more than a whisper, but a whisper audible in the remotest spot of the great auditorium, the one sentence :

"I am a spirit."

And he was a spirit. You felt it. He belonged not to this world but to another world. He was almost a disembodied spirit. His possession of a body was accidental. The essential thing was the spirit. $\mathrm{He}$ was of all time, past and future; immemorial, immortal, eternal. Whether a spirit of evil or a spirit of good mattered not. He was a spirit. That was what he meant us to understand. That is what we did understand. The laws of nature and of evidence were for the time being suspended. You took his word for it. If he had not said so we should still have said to ourselves, " $\mathrm{He}$ is a spirit." It was a spiritual presence, a dweller of another world, a being of a nature not human but divine, a divinity of the nether world; a spirit of light though the light shone from below.

Is anything but genius, and a very high order of genius, capable of producing such an effect as that ? The two Irvings met in Mephistopheles. If either of the two had been absent it would not have been Mephistopheles, or not this Mephistopheles. The slightness of his physique added to the effect. You were not disturbed by anything corporeal or gross. There was just body enough to hold the spirit; no more. And there were the eyes, luminous, haunting, 


\section{ANGLO-AMERICAN MEMORIES}

melancholy, with the far-away look in them which befitted one who had just traversed infinite space to reach the earth. It was a vision. It is five-and-twenty years or more since I beheld it, and the like of it I have never seen since, and shall never see.

Yet have I seen other actors masquerading as Mephistopheles, and one quite recently, an actor of renown, of wide popularity. The contrast to Irving is physical as well as spiritual, for it is a stout Mephistopheles which he presents to the public. He takes, and expects us to accept, a humorous view of Goethe's creation, since he has nothing to do with any other world than this, nor with this except on the stage. Goethe's Mephistopheles has a psychological significance ; or even, if you like, psychical. So had Irving's. But this latest fiend of the twentieth century is of the earth earthy. Irving regarded his victims with a smile of polished ferocity that filled you with terror. This more recent Mephistopheles leered at them and at you. He played it, in a word, as he would play the lead in a modern farce, with great abilities, greatly misused. Nothing could be more remote from Faust, in which even the scenes with Martha are pure comedy; as other scenes are pure tragedy. Irving, though the version in which he acted was but a pale reflex of the original, had found and kept the true note. He was not a man to miss the distinction characteristic of the real play. His Mephistopheles was a great gentleman, and if Mephistopheles be not a great gentleman he is not the Mephistopheles of Goethe.

In much of the drama and dramatic criticism of the day it is easy to see that the magic of Irving's influence survives. It survives, I think, because of his constant appeal to the imagination, and because of the want of any such appeal on the stage as it is. When Sir 
Herbert Tree produces Henry the Eighth and announces himself as Cardinal Wolsey, he has to confront the spectre of Irving's Cardinal. It was the same when Faust was given; the Mephistopheles of Irving haunted the stage of His Majesty's Theatre, the expression of his face more sardonic than ever.

Irving's Wolsey bore no likeness in face to Henry's great Minister, but in soul and spirit was the real thing. As you looked upon the actor you saw a great ecclesiastic. He had the finesse which is the stamp set by the Roman Catholic Church, then and now, upon all its chief dignitaries. You saw him as he moved about the stage, subtle, evasive, implacable, unscrupulous; Rome in him and about him; the Seven Hills visible and minatory. He was an ascetic. There seems to be a form of power over the minds of men not to be had otherwise than by the practice of privations. That also Irving had. It was not an effect of makc-up, but of nature. He was the Cassius of the Lyceum, lean and hungry.

There was in Irving a resemblance to Cardinal Manning-you cannot say in the flesh, for Manning had none-but in skin and bone, and, at moments, in the cruelty of his look. He was a Torquemada in all but the power to translate his cruelty into the concrete form of the rack and the stake. I disliked Manning so much that I shrink from my own comparison and from a confusion of memory in any particular between Manning, whose nature was selfish, and Irving, whose nature was generous. But the likeness was there. Irving would not have resented it. His business was to produce upon the stage the illusion of actual life, and he would have held it a compliment to be told that as Cardinal Wolsey he reminded you of a living Cardinal, whether Manning or another. What 


\section{I 8 ANGLO-AMERICAN MEMORIES}

he aimed at was verisimilitude. He must have met Manning, and while he did not consciously imitate him-in no case did he ever do that, or ever reproduce upon the stage the lineaments or bearing or dress of real life-he may well enough have been aware how Cardinal Manning looked, and the impression of that austere presence may have remained with him. Something may have passed from the soul of the one to the soul of the other, for Manning, with all his faults and some of them unforgivable, was a figure in this great Protestant community; not less so because he was a relentless servant of Rome. His biographer Purcell has laid him bare.

Irving played three great prelates; Richelieu in Bulwer Lytton's play of that name; Wolsey in Henry the Eighth; and Becket in Tennyson's metrical experiment in play writing. No one of these three impersonations was like either of the other two. $\mathrm{He}$ had studied each of the three independently. However, it is only Wolsey who concerns us to-day, and he concerns us because never before has there been such an opportunity to measure Irving's greatness as by a visit to-day to His Majesty's Theatre. Sir Herbert Tree may rightly enough claim to be judged on his own merits and not by comparison with the first of English actors since Garrick ; and, for aught we know, Garrick's equal. In what Mr. Roosevelt, steeped in literary calm, would call strenuousness, Irving was Garrick's superior, since Garrick acted, from year's end to year's end, less than twice a week and Irving six or seven times. Irving must therefore have had a much larger reserve of power, and used it much more freely than Garrick.

But I am not judging Sir Herbert Tree. That is no part of my duty. I use him, in no unkindly spirit, 
to bring out Irving's resplendent merits. For once, instead of the limelight of which he is so fond, Sir Herbert must be content to be a background. I am sure he will not object. He will rejoice to offer a sacrifice on this altar. He owes much to Irving. What living actor is there who does not? Moreover, it is quite possible to praise Sir Herbert's Wolsey. It has been praised, though with some reserve, by the public press. It has been acclaimed in the theatre. Tried by the box-office test, it is a highly successful performance. The play as produced by Sir Herbert is a pageant. Scenery and costumes are splendid. He is a manager of great energies and great capacities, and an accomplished actor of many parts who tries to look at his part, whatever it may be, with the eyes of the audience. He sits in front and brings his mind's eye to bear on his own conception and performance of Wolscy. He gives his audience little or no credit for subtlety of perception. He assumes that what they want is the obvious, the common, the everyday view. An imaginative treatment is to them, and therefore to him, superfluous.

Far otherwise was Irving's way. He did-and in this Sir Herbert Tree follows and imitates himeverything to attract an audience by splendour of mounting and dressing and by the strength of his cast. There he stopped. When he came to consider the part he was going to act, he retired into his closet and took counsel with his own soul. Into that retreat were admitted no delegates of the outside world. He forgot the existence of the box-office. He remembered only his art and himself. All his art and all his wonderful personality he put at the service of the character he was about to impersonate. New part or old, it mattered not. He composed it for himself as if it had 


\section{0}

never been played before. He knew all the traditions and of them all was independent. They were his servants; not he theirs. He took what he wanted; the rest were the property of the next comer. $\mathrm{He}$ thought out all his problems and all the difficulties of his part in his own way and to his own end. He read everything and knew what to remember and what to forget. There was no detail which escaped him, and none which embarrassed him. By reading and deeply reflecting upon the man he was to depict, his mind became saturated with this new conception. Upon it, and upon each new one in succession, he lavished, I repeat, all his gifts, all his technique, all his overmastering individuality; and of them all he made an imaginative use. His Richelieu was one thing, his Becket another, and his Wolsey a third.

His Wolsey was one of those pictures, like Millais's portrait of Cardinal Newman, which never fade from the mind. Irving had, in a measure, the benignity of Newman, in whose face benignity contended with strength. But since benignity was only an occasional and perhaps hypocritical trait in Wolsey, Irving never allowed it to be paramount. It was transitory, yet while it lasted you thought it there for ever. His face was wasted by fasting; the scourge had been laid on his shoulders; the daily torture of the hair shirt was his. In this leanness of visage lay one of Irving's resemblances to Cardinal Manning; the skin clung to the bones. But if Irving had studied Manning he made no mistake; he was under no delusion. He did not impute to Wolsey the cunning of his successor; he was clad in the lion's skin, not the fox's. The Wolsey who came down to the Lyceum footlights was he who wrote "Ego et rex meus." Punch, in describing the inventory of Sir Herbert's stage properties, men- 
tions a portrait of Tree as Wolsey, on the frame of which the last three words of the sentence have been rubbed out.

Among all the visions of all the Irvings which live in one's memory this of Wolsey is among the most vivid. He had taken the trouble to send to Rome to get the exact shade of rose-scarlet of which the silk robe of a cardinal ought to be made. I believe Sir Herbert had done the same, but he had not taken the precaution to fit it with that expression of disdainful power which Irving's face bore. The great actor of the Lyceum seemed never to care, though of course he did care, whether you applauded him or not. He wanted you to see and understand what was in his mind, what kind of character he was seeking to present to you, and to believe that while Irving was on the stage this character, Wolsey or another, was what you saw and heard. No meaner triumph than this contented him. He sometimes failed, but it was so high an ambition that when he succeeded the failures were as if they had never been. And he succeeded in Wolsey.

I have seen Irving when he had to face a hostile verdict from his own first-night public; for practically the house was on a first night his own ; with Mr. Bram Stoker as the amiable but inexorable guardian of the gateway to this theatrical paradise, since paradise it was on these occasions. Stokcr had become a kind of second self to Irving, thinking his thoughts, knowing what he wanted done, and carrying out his wishes with equal energy and intelligence. If even among this chosen company of the faithful there was discontent, and dissenting cries mingled with the cheers, Irving met them with an air of ingenuous, incredulous surprise, as if they could not mean it. He was wounded in the house 


\section{2 \\ ANGLO-AMERICAN MEMORIES}

of his friends. He did not resent it. He seemed to be sorry, not for himself but for an audience which could misunderstand so sadly. Altogether, the grand manner; neither defiant nor deprecatory but impartial, as if not he but a third person were concerned and they who disapproved were simply mistaken. I used to think these scenes among the finest in which Irving ever appeared. After a time he stilled the expressions of dissent; they died away as if in truth the authors of them had become aware they were wrong, which perhaps they did feel, and as if Irving were after all right; which sometimes he was not.

But the grand manner has departed with him; there was no one to take the torch from his dying hand. When you come to a question of personal deportment it is a delicate business and I name no names. I only ask, who among the best and most successful of the actors now to be seen in London holds his head high when he takes his call? The actor-managers are on their own ground. The theatre is theirs. They could close it to-morrow and turn their audiences into the street if they liked. Yet there are among them those who face a cheering or a howling house with the air of a tradesman in dread of offending his customers.

But Irving? Irving, without the least touch of arrogance, looked about him as a King upon his subjects. The natural majesty of the man was better seen in these crises than at any other time. He was perfectly self-possessed, perfectly fearless; while inside of him burnt a contemptuous anger he was far too much the aristocrat to show. The public liked him the better for it. He said to me once:

"I have had to make a study of audiences. I have studied actors also in their relation to audiences, and I feel sure that, whether as actor or manager, he who 
defers too much to the public loses his hold on the public. Those people in front, even if they have paid for their places, expect the actor to know his business better than they do; and even if he is wrong they like him to hold to his own view. So with the manager. They are not such fools as to think they know better than he how to stage a play. You must stand up to them. A bad first night may cost me thousands of pounds but the greater the funk I'm in the less I show it."

There is the real Irving. It was a three o'clock in the morning speech ; cool, quiet, collected, convinced, and entirely sincere. The virile note you heard from him in private gocs far to explain him on the stage. It is a commonplace to say that Irving owed much of his fame as an actor to his personality. I have said it myself. But even a commonplace may be true, and may be a compliment, as this is, for you can hardly praise an actor better than by saying that an actor's success in depicting other men is due to his own manliness.

He lives, and will ever live, in the memories of men and women and in tradition; not in books. There have bcen books about Irving which are thought to be disappointing. I am not expressing my own opinion for I have read none of them. When I have known a man, I like to keep my own impressions of him. To read a book about him, except for the facts and for the times in which he lived, is to displace or disturb one's own impressions and to accept other impressions instead. 'The picture becomes a blur. One's own memory may not be accurate, and is pretty certain not to be complete, but it is one's own.

Though he had an immense acquaintance and a vast number of admircrs Irving had not very many intimate 
friends, and there were sides of his life which, I imagine, he did not reveal even to them. In private as in public he played a part; many parts. I suppose I knew him as well as most men knew him but I was not an intimate friend. The most I could say is that there were moments of intimacy, and a long, friendly acquaintance, perhaps a friendship. I hope so.

The relation between an actor and a journalist can never be entirely unembarrassed. The journalist must speak his mind, and the actor is apt to think that criticism ought to take the form of eulogy. It cannot always, nor ought personal regard for the actor to affect the critic's judgment though perhaps it sometimes does. Whether it does or not, a great artist expects and likes recognition and he is sensitive because he is an artist. Irving could afford, if anybody could, to face the truth. He had a great public behind him. But he had men about him who sought to persuade him to resent freedom of speech. I don't think they succeeded, or ever succeeded permanently.

We all agree now that his acting was unequal; that in some things he was great; in others less great; and in some of the most famous parts he attempted, such as Macbeth, he was deplorable. The most heroic, the most masculine, the most tragic parts seemed to be beyond him. He was an ideal Iago but Othello was a sealed book to him. He could not render the majesty, the nobility, the childlike simplicity of the Moor. And Lear was beyond him; is perhaps beyond anybody.

So far as I am concerned the production of Macbeth was the critical moment in our relations, if there were ever a critical moment. I saw it on the first night, as I saw many other first nights at the Lyceum, and I cabled to $\mathcal{T}$ be $\mathcal{T}$ ribune a column of comments on the 


\section{SIR HENRY IRVING}

performance. They were not very favourable. They were not meant to please Irving, nor yet to displease him. The dispatch was a record of first-night impressions and opinions. Probably they were too blunt. The English sometimes suggest that we Americans have a habit of speaking our minds too freely; in print and otherwise. What they soften here, we say outright.

But in Sir Thomas Fuller's recent Life of Cecil Rbodes, an illuminating and most human book, he tells this story. There was an English journalist, now dead, Edmund Garrett, who was editing at Cape Town a journal called, I think, The Cape Times. He was a friend of Cecil Rhodes. Lunching one day at Rhodes's place, Groote Schur, Garrett found his host angry at an article of the day before which ran counter to his views and perhaps attacked him. Rhodes told him such an article ought never to have been published. Said Garrett :

"Mr. Rhodes, it is a good thing for you that your paper should be edited by a man who doesn't care a damn whether he pleases you or displeases you."

There was a silence. Then Rhodes answercd slowly:

"It may be you are right and I am sorry to have questioned it. I have never tried to control your policy but I think you might at least have taken the trouble to find out the facts."

I am quoting from memory but the illustration is too apt to omit. Apt because here was one English journalist, and a distinguished one, who was as downright as any American could be, and another Englishman, the greatest of his time, to whom the soft answer which turneth away wrath seemed all sufficient.

Whatever the brutality of my criticism on Irving's 


\section{ANGLO-AMERICAN MEMORIES}

Macbeth may have been, it put no real strain, or no lasting strain, on our relations. He himself preferred his Macbeth to all his other creations, or rather to any one of them. If the public did not, he rested content, I hope, with his own approval.

The range of his powers as a tragedian was not very wide. He was a comedian of the first order. The scenes with Rosencrantz and Guildenstern in Hamlet were proof enough of that. In character parts like Louis XI he was supreme. And we shall see what Mme. Sarah Bernhardt thought of him in such a play as The Bells. Take him for all in all, he was so great that nice criticism seems ineffectual. $\mathrm{He}$ is a haunting figure. He had possession of the stage and of the imaginations of men and women during a quarter of a century. He can no more be displaced than Garrick can be displaced. And even Garrick could not play everything, and in his best parts he was unequal. 


\section{CHAPTER XXVIII}

MME. SARAH BERNHARDT AND SIR HENRY IRVING -AN EVENING A'T THE LYCEUM

I GIVE Mme. Sarah Bernhardt her full name, but 1 there is no reason why I should except out of respect to the liking of New York for needless exactitudes. The full name of the greatest of all tragedians was Elizabeth Rachel Félix, but who ever spoke of her otherwise than as Rachel? In the same way, Paris always calls its present stage divinity Sarah. In early days I asked her whether she liked it and she said: "Yes, of course. C'est un hommage." The French Press used it; so I think we may, if New York does not object. I have heard it used in private as well as in public, and by men who were on no particular terms of intimacy with her.

The French season in London was over and Sarah, who was staying on for a little, asked me to take her to see Irving in The Bells. Sarah understood, at that time, little or no English and I foresaw that I should have to interpret as the play went on. But I wrote to Irving that Sarah wanted to see him. He of course was delighted and sent us his best box next to the stage. Sarah for once was punctual and we were in our places before the curtain went up.

Sarah knew very well that $T$ he Bells was founded on Le Juif Polonais of Erckmann-Chatrian. 'The story 
was familiar to her and she knew what to expect. But she had never seen Irving and of him she had no idea what to expect. When he entered she applauded, but that she always did. She had, more than any other actress I have ever known, the sense of comradeship. She was bon public. She knew what applause was worth to the actor or actress; that it is to them the breath of life. She has often told me that the want of it is, even to her, embarrassing and even distressing. A cold house is an impossible house and acting becomes impossible.

"They say I sometimes walk through my part. Perhaps I do, but if I do it is always the audience which begins the walk. The audience and the actor are two parts of the same whole, and neither can get on without the other. They say I have moods. I don't deny it, but I am never careless to a house which is friendly to me."

From the moment of Irving's entrance upon the stage she sat absorbed. Understand his language she could not but she studied the man, watched every movement, every expression, every gesture. Now Irving was before all things a personality. You might like his acting of a particular part or you might not, but you felt yourself in the presence of a man. It was a commanding and a sympathetic presence at the same time. I doubt whether Sarah had ever heard this said of him. She knew only his general reputation, and he was then at the height of his fame. But the attention she paid to him was quite different from that she gave to an actor as an actor. I sat looking, not at Irving but at her, and it was plain that his magnetism had made itself felt from the beginning. For what else passed upon the stage she had at first no cyes. There was Irving and there was nobody 
else. Presently, without turning from the stage, she said to me :

"Mais il m'énerve ; dans le bon sens, bien entendu."

No literal translation would convey to an English reader what she meant. The word hypnotize is too strong, but it may serve. Sarah was not in a trance for she was in her most critical and perceptive mood. The best proof of it was not merely what she said. I soon found that I was seldom wanted to translate. Knowing the plot and the general course of the play, she was in no difficulty as to what was going on or about the stage business. But from Irving's expression and gestures she inferred what he was saying; what he must be saying. This was to me a new kind of thought reading and it appeared to be, unlike thought reading in general, unerring. I had seen Irving often as Mathias. I had never seen him play the part with the same precision, the same abundance and accuracy of detail, the same illuminating touches both in the great scenes and in the ordinary progress of the play, or the same inspiration. He was playing to Sarah. She was the inspiration. He knew that she knew no English, and in order that she might appreciate the whole he was playing it in pantomime. He seemed to have forgotten all about his voice, and his voice, left to itself, grew stronger and clearer and more melodious. Sarah said:

"Why do they find fault with his voice? The tones are pure and full, the sentences flow smoothly, his elocution is rhythmical and distinct."

She began after a time, in the commercial phrase, to take stock, not of the man only but of the actor:

"But he is a great actor. He does things, some things, which no French actor can do. He makes no mistakes. He never misses a point. He does what 
he likes with his audience; yes, with you and me as well as the rest. Don't tell me you don't think him great."

I did not tell her that, for I did think him a great actor; in the right parts, and Mathias was one of them. The Bells, of course, is a play to which you must give yourself up. You do not surrender your critical faculty but you must accept the atmosphere; and live and move and have your being in that atmosphere till the curtain goes down. I thought of what Sarah had said about Coquelin; an actor, but not an artist. But she thought Irving an artist also. He had the art temperament.

Nor was she disconcerted by such things as the throwing open of the door of the great stove, and the firelight flaming out blood red on Irving's face.

"C'est un gros effet, mais c'est un effet."

In other words a legitimate effect, an appeal to the less delicate intuitions of the audience; to the men and women who required at every moment and by all just means that the identity of the murderer should be brought home to them.

Mr. Henry James said of Irving in The Bells, "You would know him for a murderer a mile off." The inevitable exaggeration of the epigram is there; and the grain of truth also. Mr. James said it rather too contemptuously. It was a reproach. Mr. James has a great knowledge of the theatre and is a critic of renown. But he did not in this instance distinguish between his own perceptions and those of the audience in general. He did not himself require to have it brought to his attention that Mathias was a murderer. He forgot that the average playgoer might wish to be reminded of it. And Irving, like that great comedian at the Bar the late Lord Russell, had two sides to 
his face. He wore a mask to the personages in the play, and on the uncovered half of that speaking countenance he allowed the spectators to see the ravages of remorse and the stamp of guilt which betrayed his guilt to them, but to them only. Having Mr. James's remark in mind I asked Sarah if she thought he made his crime too evident. She answered:

"Certainly not. He is a murderer and these suggestions of guilt are so many psychological truths. No criminal ever hides his crime completely; least of all on the stage. And you must never perplex your audience. Especially an English audience. If you can imagine yourself on the stage your suspicion will not be excited."

So I think we may set Sarah's testimony against Mr. Henry James's and rest in the comfortable belief that Irving knew his business. His method in this matter was indeed part of his stage management. He did not restrict stage management to mechanical or artificial arrangements. His ideal, in respect of elocution and of the tuition of individual actors and actresses, came far nearer to the French ideal than that of other English managers. Sarah thought him far and away the best she had ever seen.

"Not at the Français itself have I ever seen anything so good. The way in which he uses the lights is his own. No stage in France is lighted as this is. None has the same scheme of illumination or uses it in the same way. The groupings are just as good, and all the stage business shows a master hand."

She asked if I knew whether Irving himself looked after this all. I said yes. It's not only a master hand but a master mind; and it is Irving's. He has, of course, able lieutenants but the conception is his and at rehearsal no detail escapes him. 


\section{ANGLO-AMERICAN MEMORIES}

"I was sure of it," said Sarah, and added:

"It's not merely that the details are so well considered but there's a general effect which I can only call imaginative. Whoever staged this play had in his mind from the beginning a complete conception of the whole, as a whole. He saw it all. He understood the relation of each part to the whole. What you do not see is almost as remarkable as what you do see. He has known what to leave out. I am certain he has suppressed much, and either deleted or modified points which were good in themselves but not good for the general impression of the piece. He is an artist who understands that nothing is good unless in the right place. Stage management in his hands is an intellectual triumph. He has not his equal among us."

Yet I had often heard Sarah describe and extol the sternness of the discipline on the stage of the Français. There the régisseur is master. He is more than master. He is a despot.

"He has made me recite a single line fifty times till I delivered it to please him; me, Sarah!"

But in the rehearsal of a new piece the author steps in. He is then the despot, and from his decree there is no appeal.

When $T$ be Bells came to an end Sarah turned to me with a long sigh:

"I feel as if I had been acting myself. I have never spent such an evening."

But the end of the evening was not yet.

\section{II}

\section{A LYCEUM SUPPER- " LA TOSCA" IN PARIS}

No, it was not the end of the evening. I had seen The Bells and Irving anew, through Mme. Sarah 
Bernhardt's eyes; understanding the play and the actor more completely than ever before, by help of her intelligence. When she chose, that great actress could be a great critic; appreciative, sympathetic, kindly; but always loyal to her art. What she had said of Irving, she thought. She may have said less than she thought but never more. She had seen in him those qualities which had created for him a place by himself; and put him in a class by himself. Sometimes denied to him by English critics, this most subtle of French critics had recognized them.

Criticism in France, whether dramatic or other, is a more exact science than criticism in England. When it is dramatic, its relation to the stage is far more intimate than here, where the critic has but seldom the training or equipment which only a knowledge of the stage, and of acting as seen on and from the stage, can give. Sarah, of course, had this last in a supreme degree. She was quite free, moreover, from jealousy. Some of the French actors who came here were not. Coquelin was not; though in his case there was a feeling which predominated over jealousy. He held his own art to be so immeasurably superior to all others that he did less than justice to others. But, as we have already seen, Sarah thought Coquelin an actor but not an artist. Ever since this night I have found Sarah's eulogies upon Irving the best answer to Irving's detractors. If the detractors were not convinced they were silenced.

Irving had asked us to come to supper after the play, in the Becfsteak Rooms in the Lyceum Theatre. With a merciful kindness and tact for which we were both grateful, he had asked nobody else. The Becfsteak suppers were often delightful but, as Sarah 


\section{ANGLO-AMERICAN MEMORIES}

and Irving had never met, this was to each of them a chance of knowing the other too valuable to be thrown away. A free talk between two people who had no language in common was difficult enough at best. Irving had no French and Sarah had no English, so that in a company there could have been no meeting of minds. By themselves, with an interpreter, it might be managed.

They met on even terms. Irving had when he chose the grand manner and so had Sarah, and both were on their best behaviour. Irving received his guest with distinction, and Sarah greeted her host with just that touch of ceremony which is expected on the stage; to be dropped instantly for a cordial acceptance of his welcome. She thanked him for the box he had sent her and burst at once, like the true Frenchwoman she was, into a shower of compliments on his Mathias.

Said Irving in his polished way:

"They are compliments which I cannot deserve, but I like to have them and I acknowledge them as compliments."

But Sarah broke in:

"No, not compliments; not as between artists. I offer you none. I owe to you the truth. You can afford to hear it, as I could."

Her compliments, or whatever they were, had to be translated sentence by sentence into English, so that the full effect of the explosion was missed, but it was none the less overwhelming. The colour rose in Irving's pale cheeks, and spread, and the eyes grew luminous and deep. He was not sure what impression he might have made on a French mind. He coveted Sarah's praise and he had it in full measure. He asked me afterward whether she had said to me 
in the box as much as she had said to him and when I told him "More," he was content.

When we sat down to supper the talk turned upon things dramatic. To that they kept, and they discoursed through nearly four hours. They discussed technicalities, and technicalities of the stage are not always easy to translate from French into English or vice versa. The drama has a vocabulary of its own. But if I did not know both French and English for a particular term I could generally paraphrase, and so the extraordinary conversation flowed on. If it was difficult it was illuminating. Here were the two consummate artists of the French and English theatre; the greatest French actress, the greatest English actor; and each of them with a more complete knowledge of all matters pertaining to the theatre than anybody save the other. As I listened I felt how little experience had taught me and into what new realms of knowledge I was being shown the way. I had never learnt so much as I learnt in those hours.

Nor was it only the things of the stage. I had known both Irving and Sarah long and well. But here was a new Irving and a new Sarah. They revealed themselves to each other, and incidentally to me. For the first time I felt as if I were seeing the theatre and some of its mysteries from the inside. I saw, at any rate, what it meant to those who were of the mystery themselves. The talk was simple, true, direct. They put off all artifice, pretence, disguise and the masks they wear to the public. The two artists opened their souls to each other, and in their frankness, in their half-unconscious disclosures of their real natures and their real thoughts, they were more admirable than ever. The intuitions of art stood to them in the place of that community of speech 


\section{ANGLO-AMERICAN MEMORIES}

which was denied them. They had more than their art in common. They were sympathetic to each other. They made friends.

I will go so far as to say that here, and in the most unlikely way, was a beginning of that better understanding between England and France which was in later days, and under an august inspiration, to take the place of old enmities. In London and in New York that may seem an exaggeration. It would not seem so in Paris where the theatre has a direct and continuing influence upon life and upon opinion. Nor need it seem so even in London; or not always. You would not think so if you had seen Sarah holding a court in her art gallery in Piccadilly to which came men and women of great distinction in great numbers. Last of all Mr. Gladstone came also, whom Sarah received d'égal à égal, as Victor Hugo said he received the Emperor of Brazil. The company fell away, leaving as for royalties an open space about the two, and they conversed apart for some minutes. Perhaps that also was another beginning of the later entente. Or you might date it, if you liked, from Mr. Gladstone's appearance at the theatre when Sarah was playing Pbédre; the old man in a stage box, leaning forward; a book of the play before him; his hand to his ear; his blazing eyes fixed mostly on the tragédienne, for he needed the book only on account of his deafness; and, when it was over, going behind the scenes to offer his homage to the artist.

But I like to think of Sarah and Irving as having planted the first seed. It was not known. The newspapers published no account. If Paul planted there was then no Apollos to water. But it came up as a flower if not as a tree; it had fragrance if not strength; and it had beauty. 
One hears of girls who wish to go on the stage because they think it an easy life. They might take a lesson, or several lessons, out of Sarah's life; a life of great successes won by tremendous efforts. The public thinks her a genius, and these girls think that because of her genius she may dispense with study and the drudgery of the profession. Sarah herself never thought that. I will offer these ambitious young ladies one example of her method.

When La Tosca was produced in Paris at the Porte St. Martin I saw it the first night. During the second entr'acte I went to Sarah's dressing-room to pay the compliment one is expected to pay in Paris if one knows the actress. She was playing, we all thought, her best. The success was brilliant, the applause unstinted. Needless to say that no French author, and certainly not Sardou, would allow his piece to be produced until he was satisfied with the rehearsals. Still less, perhaps, would any actress of Sarah's position come before the footlights until her own conception and composition of a new part were to her mind, and until the ensemble was complete. In Paris these things are taken for granted. The French critic is inexorable; the French audience not less so, and a play not perfectly rehearsed would get scant mercy from either critic or audience.

The next morning I left for Italy, was gone six weeks, and on returning to Paris went again to see La Tosca, and again between the acts went round to see Sarah. I said:

"You are in great form to-night. It is much better than it was on the first night."

There came into the face, and especially into the eyes, of the actress one of those challenging looks one saw there when she was in a warlike mood. The 


\section{ANGLO-AMERICAN MEMORIES}

blue of the eyes, sometimes soft, hardened into the famous bleu d'acier, with points of flashing light as hard as the steel-blue itself. I saw the storm rising but I had no idea why. She stood silent for a second or two as if to allow her mood to be seen; then in her most metallic tone :

"Ah, you think I play my part better than when you first saw it?"

"You certainly do."

"And you think it is because I am in good form to-night?"

"Well, you certainly are in good form."

"Merci, mon ami. But you are right about one thing. It is better than it was the first night, and I will tell you why it is better. It is because I have worked on it six hours a day for six weeks. That is why."

My mistake had been in suggesting that the improvement was because of her being in good form that particular evening. She wanted credit for her six weeks' hard labour. She was then at the summit of her fame. She had done her best with her part for the first night. She had satisfied her public, and the Press, and Sardou. But because she had not satisfied herself, the artist that was in her, she toiled on. And that is the history of Sarah Bernhardt's art life. 


\title{
CHAPTER XXIX
}

\author{
MR. THEODORE ROOSEVELT *
}

AS POLICEMAN AND AS GOVERNOR OF NEW YORK STATE CONG before Mr. Roosevelt became famous I knew him; and during the height of his fame; and now that it seems, for the moment, a little obscured I think I may set down a few impressions. We were told here that, since the unhappy results of his attempt in the autumn of rgro to resume control of the Republican Party, he had been laid gently on the shelf, and that the American people were willing he should rest for a time from his arduous labours in their behalf, But the English who have seen something of Mr. Roosevelt seem to doubt whether he will ever be content with a shelf as an arena for his quenchless energies, or ever consider himself in need of a rest. Said Carlyle of Bismarck, in $\mathrm{I} 866$, after he had brought Austria to her knees:

" $\mathrm{He}$ is the only man who has been appointed by God Almighty his Vicegerent here on this earth, and knows that he has been appointed."

I am very far from meaning to suggest that any parallel can be drawn between the creator of the German Empire and Mr. Roosevelt. It is however possible that the ex-President, while he was President or even before and since, conceived that his mission,

* The first four of these Roosevelt papers were written in August, I9I I; the last two in November and later. 
or commission, was apostolic. Even in England he thought it his duty to preach the gospel to the heathen. He would not have been rude enough to describe his admiring hosts as heathen, and he did not. But it was felt that, to Mr. Roosevelt's mind, the heathen were, and always are, those who did not agree with him, or did not act as he would have them. But I must leave England till its turn comes.

My experiences of Mr. Roosevelt relate largely to his official life; necessarily, since till he ceased to be President he had been almost continuously in public life for near thirty years. But they will be personal reminiscences and impressions; not historical. As I was abroad during his legislative and Civil Service career, I begin with I $895-7$ : the years during which he was President of the New York City Police Board. He said to me one cvening:

"Come to the Police Head-quarters to-morrow morning at eleven. We are going to hold one of our weekly courts, and you might like to see how the police Commissioners administer justice on their own men."

It was interesting enough ; perhaps chiefly interesting to a lawyer from the disregard of legal methods and of the ordinary rules of evidence. Mr. Roosevelt had his own rules for getting at the truth, but the truth and only the truth was what he wanted to get at; and perhaps generally did. His intuitions were almost feminine; his fairness was conspicuous; and mercy went with justice; a much-needed handmaid. When we left the court-room for luncheon, on foot and at race-track speed, I asked Mr. Roosevelt whether he found police work interesting.

"Interesting? I've never had such fun in my life."

"Fun." That struck a keynote. Much later, and in very grave circumstances, Mr. Roosevelt 
showed himself capable of taking humorous views of affairs, and of extracting fun from them. Whether his fellow Commissioners got as much fun as he did out of it may be doubtful. He treated them with civility, with consideration, but the opinion he respected was his own.

New York had experience of this respect for his own opinion in very serious matters; some of them serious enough to interest Europe, and to fill much space in The Times. In the midst of one such crisis I went to Oyster Bay for the week-end. Sagamore Hill was not then so large a house as it is now, nor had Oyster Bay become a world-famous name. One important English journal believed it to be in Florida. The charm of it, apart from pleasant scenery, was its simplicity; an American, or what Jefferson would have called Republican, simplicity. Mrs. Roosevelt ruled over it with a gentleness, a composure, which more or less disguised the firmness beneath. I heard it said long afterward that hers was the influence which weighed most with her husband; at critical moments and in the ordinary course of life. I can well believe it. Later, and in far other circumstances, the atmosphere of Oyster Bay was to be breathed in the White House.

I should say, though probably I ought not, that throughout his public life and in all his intercourse with all sorts and conditions of men, it was Mr. Roosevelt's aim to convince them that his and their views of social life were on a level. The fact remained that he was born and bred what is called a gentleman. I do not mean to suggest that he sought to disguise it. What he sought, or what he suggested, consciously or unconsciously, was the essential oneness of all honest and honourable men, to whatever station in life they 
had been called. Neither riches nor social rank counted. What counted was the manliness of the man. Given that, he could accept-I had almost written tolerate-much. At Oyster Bay he had something to accept. For one reason or another uncongenial personalities were to be met there, and therefore it was that I then had the chance of observing the large Democracy in his character and nature. $\mathrm{He}$ cared little or nothing for mere observances from those who were in a different class. But let a man in his own class forget himself and he was quickly reminded of his lapse. Not long after he had been chosen Governor such a man, a friend, hailed him in a New York club: "How are you, Teddy!" There came a look into Mr. Roosevelt's eyes which induced his friend to add: "I beg your pardon; I mean Governor." Whereas from the multitude he seemed to regard "Teddy" as a term of affection, or perhaps of respect.

At Oyster Bay he came into the room where I was looking over a completed cable dispatch to $\mathcal{T}$ be $\mathcal{T}$ imes. It related to a subject we had been discussing, and I saw what I thought an inquiring look in his eyes, and answered, "Yes, it does." As the look of inquiry persisted, I said:

"It's rather against rules but there's really no reason why you shouldn't read it if you care to."

And he did; handing it back with the remark:

"But your point of view is very American."

"Why else do you suppose The Times chose an American as its American representative? It's the American point of view they want. No other could be of so much use to them."

Which I thought obvious, but it seemed slightly to surprise Mr. Roosevelt at that time. 
His belief in himself and in his own opinion was presently to become so familiar to the American people that it is needless to dwell on it. But his friends first knew how complete it was when he threw up his Assistant Secretaryship of the Navy to enlist his regiment of Rough Riders and take them to Cuba for what we called the Spanish War. All his friends advised him against it and told him he was sacrificing his future; the prophetic vision not being theirs. $\mathrm{He}$ answered:

"If I believed it would end my career I should none the less go. I have urged on this war. If I should stay in Washington while it is fought I should be disgraced; I should be ridiculous."

And thus it was that he came to be the historian of those military excursions in $\mathrm{Cuba}$, and to give Mr. Dooley the opportunity of writing his masterpiece on Teddy Alone in Cuba; with a lunch at the White House as his reward. For "Teddy's" temper was proof against the Irishman's " fun."

However, in those days the American people took serious views of the Spanish War and have had occasion to take serious views since; and of $\mathrm{Mr}$. Roosevelt as Governor of New York and President; a child of the War. Some time after he had been installed as Governor I spent two or three days with him at Albany in that "Executive Mansion" which the State provides as a residence for its Chief Magistrate. Mrs. Roosevelt was away and my hostess was a young lady whose name has since floated round the world; then a girl of fifteen, with a brilliant manner and a friendly conception of her duty to her father's guests which captivated them all. Even in her early girlhood Miss Alice Roosevelt was very competent, thoughtful, picturesque, with an inexhaustible stock of pleasant 


\section{ANGLO-AMERICAN MEMORIES}

surprises. Said Governor Roosevelt next morning at breakfast :

"I want you to come to the State House and spend the day with me in the Executive Chamber. You shall see everything and hear everything. I want you to know how the State of New York is governed."

We walked over. Republican simplicity and a certain carelessness of tenue was still the note, as at Oyster Bay. The Governor kept no state and took little thought of appearances. For his progress through the streets of his capital he wore a lounge suit and a soft, black, shapeless, slouch hat; but he walked as if his time belonged to the State and every minute had a value. From ten o'clock till six in the afternoon people flowed into and out of the Executive Chamber. Politicians, many of them, to whom politics were the most important business of State, but many who had real business to transact. The Governor sat at his desk; his visitors sat or stood as the case might be. Some were dismissed with a few decisive words; the Governor judged from an opening sentence or two how much time need be spared to each. They came from all over the State, on every sort of errand. There were State officials, municipal also, though I cannot recollect that Tammany had a representative that day; and private citizens not less important, some of them, than the holders of State office. The Corporations were there; especially railway corporations; a College President; and the Speaker of the Assembly. The procession that moved through the Chamber was a microcosm of the State. When secretaries came in with papers to sign I was asked to look at some of them. When a Senator approached the Governor, to him I was expected to listen as to lesser men; to his surprise and perhaps displeasure. At five 
o'clock arrived the reporters, to whom the Governor gave audience in mass. He and they were evidently on good terms. I had never seen the interview transacted in that way and when I remarked on it he said :

"But don't you see what a convenience it is? I am left in peace all day, and they all know that at five o'clock they will all hear all the news there is, and to no paper is any preference shown."

Excellent, no doubt, from the Governor's point of view, but it reduced journalism to a kind of trades union level with its "one man as good as another" maxim; equalizing chances but neutralizing the advantages to which superior energy and capacity were entitled.

An interesting day all through and I learned my lesson, though not perhaps just the lesson I was meant to learn. As we walked away from the State House the Governor asked me whether I now understood better than in the morning how the State of New York was governed.

"Yes, I think I do."

"Well, what do you say ?"

"All I can say is that the State seems to be governed by the will of Theodore Roosevelt."

An answer which he did not appear to expect, but it was inevitable. In view of all that has since happened it has become a commonplace.

There was a dinner in the evening with a company of guests various enough to show, as perhaps it was meant to show, how little politics were allowed to affect social relations. There were men of all parties and of no parties. Tammany was there in the person of an eminent East Side district captain. The Court of Appeals was represented by one of its best judges. 


\section{ANGLO-AMERICAN MEMORIES}

There were law-makers and law-breakers; and the judiciary to hold the balance even between the two. The Governor had laid aside his robes of State, if he ever had any, and was no longer Governor but Theodore Roosevelt; genial, cordial, making no distinction of persons; his guests all on an equality so long as they were his guests. Yet the note of authority was never long absent; it was only softened because we were guests and he was host.

\section{II}

AS PRESIDENT OF THE UNITED STATES

The two or three days I spent with Governor Roosevelt at Albany left me with the impression that his masterful good intentions would lead him far. We all now know that they did, though whether we have even yet measured the whole distance may be a question. For the considered judgment of the community embodied in statutes he seemed to have less respect than for his own individual opinion. He had, I thought, less reverence for law than most Americans have; or once had. Those who have studied his seven years' Presidency will judge whether the impression derived from his Governorship was right or wrong.

It was my business during five of those years to follow him step by step and to compose a daily history of his administration for $\mathcal{T}$ be $T$ imes. I saw him often. Sometimes he sent for me. Sometimes I asked for an audience. He talked, as a rule, freely; not always for publication. He meant to hold the balance even as between all journalists and all the papers they represented. I rather imagine that if ever by inadvertence 
he did not, he was sharply reminded of it. If -it can only have been seldom- T he Times published a piece of news exclusively, he or Mr. Loeb, his secretary, would be asked why favour should be shown to an English paper, or to me. I do not think it ever was shown intentionally. The President knew, of course, that any such news would be re-cabled to America and he had no wish to rouse needless jealousies. Whatever kindly feeling he might have for me his instinctive preference would be for an American rather than for an English journal.

His Americanism was a prevailing, continuous, overmastering passion. He was American all the time; and perhaps quand même. Whether England then came next, longo intervallo, after America, I should doubt. During the Boer War his sympathies appeared to be with the Boers. Dutch blood flowed in his veins, not a drop of English, as he himself often said. He took pains to be civil, and something more than civil, to the Irish enemies of England. There came a change, but he does not seem to have been one of those Americans who in I 898 were convinced by England's resistance to European intervention in behalf of Spain that England was really our friend and not the enemy held up to execration in America's schoolbooks and in Senator Lodge's biographies. Possibly it was not till Mr. Hay's farseeing diplomacy brought the United States into the circle of world-powers that President Roosevelt perceived clearly why co-operation between England and the United States was for the interest of both; and for ours not less than hers.?

Next after Mr. Hay, it was perhaps Lord Pauncefote whose influence on the President led him gently to an attitude of benevolence toward the Mother Country. He accepted Lord Pauncefote as a type. 


\section{ANGLO-AMERICAN MEMORIES}

The British Ambassador had a directness of method and a transparent honest sincerity in all his dealings which profoundly impressed the President. He knew that when Lord Pauncefote said a thing it was so, and that in all Anglo-American issues the Ambassador's voice was the voice of England. Therefore it was that the German cabal in 1902 against Lord Pauncefote left the President cold; or, rather, to speak more truly, impelled him to reject the Berlin story and to make it the occasion for a noble tribute to Lord Pauncefote and a complete public recognition of his friendship for America. He expressed it to me. It was not asked for, and it was almost the only occasion on which the President allowed himself to be quoted at first hand. "You may say I said it, but not that I said it to you."

With all due reserve in great matters and with strict precaution President Roosevelt, like Governor Roosevelt before him, was ever ready to take the Press into his confidence when he could. The Press owed him much, and he owed much to the Press. He made use of the Press; a most skilful and legitimate use; and not of the Press only. He said to me once:

"You think I am impulsive and perhaps I am. But I will tell you one thing. Never yet have I entered upon any great policy till I was satisfied I had behind me a great body of public opinion."

Some of this evidence of public opinion he must have derived from the Press, and from representatives of the Press. He could, and did, put questions as well as answer them. He held that a journalist who knew his business must know what was thought and said in his own constituency. From some other and not less useful sources of information he deliberately cut himself off. He set the business world against him ; and 
the big men of finance in New York and elsewhere had no reason for giving him help or expert counsel except where some great public interest was concerned. In the year of the crisis and shortly before the climax of it, I was for six weeks in and about New York. I met a great many people, some of them among the most important in the world of finance and business. Neither from any one of them nor from any other human being did I at that time hear one good word said for the President. He had alienated the business world. He was hated. They thought him a menace to peace and prosperity. Yet somehow or other the President knew what was going on in those upper regions. I should think no President was ever better served; and surely no President was ever more adroit in tapping the sources of opinion. He had his own standard of values. At one critical moment he said :

"I have means of knowing that the thirteen Bishops of the Methodist Episcopal Church are with me. That being so, I don't care who is against me."

He liked to declare himself in that large way, but of course he did care very much who was against him. What he meant was that the thirteen Bishops were representative; that they did not divorce religion from politics; that their authority over their millions of co-rcligionists was great, and that they spoke for these millions as well as for themselves.

That sense of "fun" which came out in the Police Commissioner was not always repressed in the President. As I sat with him in his private room we saw through the open door into the Cabinet chamber two men enter.

"Do you know these men?"

"No."

"They are men in whom America is just now much 


\section{0

interested; Reynolds and his colleague whom I sent to Chicago to inquire into the stockyards and slaughterhouses. Part of their report, enough for my purpose, has been sent to Congress and no doubt you have read it. The rest is too awful to publish. You would like to see it, wouldn't you ?"

"Yes."

"You never will."

Often enough the surprise in which he delighted came in a different way. During a crisis which affected England as well as the United States he sent for me and began :

"I am going to talk to you in confidence; not a word for print. I think it desirable you should know privately what the view of the Government is and what, in certain contingencies, I intend to do."

His statement lasted for twenty minutes. He talked with that lucidity and force which came to him when he dealt with great affairs. Now and then I asked a question which he answered without reserve. When he had finished I said :

"I, of course, understand that what you have told me is not to be repeated. But may I say that from a talk I have had with a high official authority I draw such and such conclusions?"

The lips parted over the white teeth, the eyes gleamed behind the glasses, and the President answered:

"That is why I sent for you."

I was to take the responsibility and not he. It was my business to take it, and I did. If my conclusions had been challenged I had all the evidence to support them and could have used none of it. But that is one of the risks which a journalist has to accept. In fact, there was no challenge from any quarter worth noticing, and $T$ be $T$ imes dispatch 
had, I think, the effect the President meant it to have.

One other detached and I hope illustrative anecdote.

When I came back from Ottawa with Sir Wilfrid Laurier's authority to repeat to Mr. Hay and the President what he had said to me about Alaska, I brought with me a long memorandum which both the Secretary of State and the President read. It contained the substance of several conversations and a statement of what I believed Sir Wilfrid ready to do. I have always thought that if the President had then had a free hand, he would have been disposed to avail himself of this knowledge of what was in Sir Wilfrid's mind, as a basis for negotiations. But there stood the Senate, in its most implacable mood, and neither Mr. Hay nor the President thought the moment propitious for approaching that august body with any fresh proposals. I was given to understand that, much as the Canadian Prime Minister's desire to close the controversy was appreciated, no step could then be taken. During a long audience I pressed it as much as I thought permissible, and finally said to the President I was still unwilling to take No for an answer. I felt that he was as unwilling to give it as I was to take it. He answered:

"Well, you are coming here this evening and I will consider the whole question meantime. Stay on after the others are gone and we will have a final talk."

Mrs. Roosevelt had a reception after the dinner and it was past midnight before her guests departed. Then Mr. Roosevelt and I tramped up and down the long passage between the East Room and the Conservatory till half-past one. At the end the President said :

"I am very sorry but it must be No." 
“Then I can only say good night. I oughtn't to have kept you so late."

"Late? You think I am going to bed ? I have a hundred and sixty pension bills to read before I turn in."

"Why not veto them all unread ?"

" 'That's easy for you to say but did you ever hear of the Grand Army of the Republic ?"

Upon which we parted. Politics had to come in. They often had. They were never very far from the President's mind. An old and loyal friend of his said to me :

"No man's sense of public duty is higher than the President's but he is the 'slickest' politician of them all. He can give points to Platt or anybody else. And yet he somehow manages to put duty first and politics afterward."

An appreciation which I hope Mr. Roosevelt will himself appreciate.

\section{III}

\section{AS PRESIDENT IN RELATION TO FOREIGN AFFAIRS}

The confidence, the deserved confidence, President Roosevelt had in Mr. Hay led him to give his Secretary of State a free hand in most matters which the Department of State had to deal with. He knew well enough that Mr. Hay had relinquished the Embassy in London and become Foreign Minister against his own wish upon the summons of President McKinley. He knew that Mr. Hay would have preferred, for personal reasons, to leave the Department upon the death of Mr. McKinley. He knew that in this matter, as in others, a sense of public duty prevailed with Mr. 
Hay; and a man with an overruling sense of public duty was the kind of public servant Mr. Roosevelt was always looking for. He knew also that Mr. Hay's experience as Ambassador abroad and as Assistant Secretary of State at home had given him the training and experience which neither natural abilities nor missions from on high could replace. In this case, therefore, the President acted, so far as it was in him to act, on the maxim to choose the best man, hold him responsible, and judge him by results. As the results were, among others, to give the United States a place in world politics and an opportunity of exercising the kind of missionary influence dear to the President, he may be supposed to have been content, and more than content, with these results.

When, therefore, the President and the Secretary were agreed on a point of foreign affairs vital to the national welfare and to peace, as in the Alaska Boundary and Sir Wilfrid Laurier's proposal, there was in the minds of most men a presumption that they were right. But not in the minds of the Senate. I do not wish to go over again a matter on which I have written much. In what I said of Sir Wilfrid Laurier in these Memories I told as much of the story as I well could. I refer to it once more only to add that after the midnight talk with the President, briefly referred to in a previous letter, I came away convinced that President Roosevelt saw eye to eye with Mr. Hay and both with Sir Wilfrid Laurier. The Senate, and the Senate only, then stood in the way of a favourable settlement of that menacing question. It is well to keep that in mind. For once more to-day the Senate, and the Senate only, ${ }^{*}$ stands in the way of those arbitration treaties with England and France which President Taft

$$
\begin{aligned}
& \text { * But now, March, 19r2, reinforced by Mr. Roosevelt. } \\
& \text { z A }
\end{aligned}
$$




\section{ANGLO-AMERICAN MEMORIES}

framed and signed. Nothing, not even Mr. Hay's diplomacy, ever did so much to give the United States a foremost place in the world's diplomacy. No President ever originated a scheme of peace so farreaching and beneficent. If it be too far-reaching, time and experience will set that right. But to peace and to American leadership in a great world-policy the Senate prefers its own usurped privilege, its own jealousy of constitutional executive authority, and the present animosity of some of its members to one of the greatest of Presidents.

I do not know whether Mr. Roosevelt has thought of writing a history of his own administration, or of those policies and acts which made it memorable. If I were a publisher I would never leave him alone till he had promised to do it ; not in detail but broadly, and therefore briefly. It would be interesting to see if he could be brief, and whether, if he were, his written style might not gain in clarity and balance. It would be still more interesting if he should condense into a chapter his relations with the Senate and his judgment on that policy of obstruction and treatywrecking which has filled the American mind with distrust of its patriotism.

It was understood at the time that one reason for the appointment of Sir Michael Herbert as British Ambassador in succession to Lord Pauncefote was the relation of friendship existing between Sir Michael and the President. That is but one example of the weight which the personal wishes of a President may have abroad as well as at home. I don't enlarge on it, for I hope to write more fully at another time concerning Sir Michael and his services to both countries as Ambassador. It is true that a European Government always considers whether a candidate for a high 
diplomatic post is likely to be agreeable to the Government to which he is sent. But it is also true that the question seldom turns on the other question of personal intimacy between the Head of a Government and the proposed Ambassador or Minister. Mr. Roosevelt's personality had won him a kind of prestige abroad which made the intimation of his liking for a particular man a powerful factor in his appointment. I doubt whether any similar case can be cited from the past. But I am quite sure that were any of the great Embassies now to fall vacant President Taft would be informally consulted about filling it, for President Taft has succeeded to that European heritage of fame and confidence which President Roosevelt was at one time supposed to have carried into retirement with him.

There was, I suppose, no European ruler with whom President Roosevelt stood on terms of such close intimacy as with the German Emperor. Down to the time of Mr. Roosevelt's progress through Europe and visit to Potsdam, the two had never met. But events had brought them together. They corresponded by cable and by letter. They exchanged gifts. The German Emperor seems to have misunderstood the President on more points than one. It was partly because of the supposed German sympathies or prepossessions of Mr. Roosevelt that Prince Henry of Prussia was sent to the United States on that mission of which the political purpose was at first denied and then admitted. When Prince Henry went to Washington Mr. Roosevelt reccived him cordially. They spent much time together; dined, walked, and rode together. The papers were full of it. I imagine the Prince thought he made a certain degrce of progress with his mission; which was nothing less than to 


\section{ANGLO-AMERICAN MEMORIES}

drive a wedge between England and the United States to the profit of Germany. I was in Washington not long after and said to the President in answer to a question :

"Mr. President, it seemed that all through your reception of Prince Henry you meant to emphasize the personal side of your relations; as if there had been no political or diplomatic side at all."

"Ah, you noticed that, did you ?"

He said neither yes nor no but I hope I may add that the expression of his face seemed full of meaning. It was an expression of assent. He meant, indeed, that his personal attitude to the Prince should be seen of all men. He knew very well what was in the mind of the German Emperor. Later the President was asked :

"If there arose between Germany and the United States a controversy, how much would the mission of Prince Henry affect the policy of your Government touching that controversy ?"

"By not so much as the weight of my little finger," answered the President.

The phrase " my Government "was almost as often in his mouth as the phrase "my policy." So it became a custom for others to say to him, "your Government."

When Baron von Holleben, the German Ambassador at Washington, went home on leave of absence he brought back with him an account of the audience granted him by the Emperor, saying in substance :

"His Imperial Majesty asked me many questions about the President, which I answered as freely as I thought consistent with the respect due both to the Emperor and the President. I had always considered 
they had much in common, personally and as rulers. Of course, I could not say that to the Emperor but I answered his questions in such a way that presently he exclaimed :

" "Why, Mr. Roosevelt must in some respects be very much like me." "

The German Ambassador gave his account of this incident to the President, and the President in turn repeated it to various persons. All their narratives agreed in substance, so the Holleben story may be accepted as true. He was not the man to have invented it; nor had he in any high degree the gift of imagination; nor would he risk incurring his master's wrath by an inaccurate version of a story sure to find its way back to Berlin and to Potsdam. Mr. Roosevelt's admiration for the Kaiser was such that he cannot have taken his friend's comparison amiss.

There were, however, critics who held and expressed a different view. 'To establish a likeness of character between the Kaiser and the President was, if you listened to them, to establish a likeness of conduct. It helped to explain to their minds Mr. Roosevelt's preference for arbitrary methods. The Kaiser, as we all know, is the ruling force in Germany, and still more is he, as King, the ruling force in Prussia. Neither the Reichstag nor the Landtag is a good example of what we understand and intend by representative government. The efficient principle, alike in the Empire and in the Kingdom, is not Parliamentary but Kingly. And there were at that time many men in both Senate and House of Representatives who thought they discovered in Mr. Roosevelt a disposition to put his own convictions of right above the considered convictions of the American people expressed in statutory law. Mr. Roosevelt, according to a cable 


\section{8}

dispatch from Washington to the London papers, said to the investigating committee which, during the summer of I9I I, inquired into his action in promoting or permitting in 1908 the sale of the Tennessee Coal and Iron Company :

"What I did was absolutely wise and absolutely right."

His critics seem to think he violated, or to say the least disregarded and enabled others to disregard, the law. I have heard that opinion expressed in England where the phrase " dispensing power" has a sinister historical significance. And I have heard Newman quoted as saying, before he went to Rome :

"The Pope's claim to infallibility implies an additional claim. He must not only be infallible but infallibly certain he is infallible."

That Pope and Kaiser and President were all acting from high motives and from a profound belief that they were doing good in the world is in each case equally evident.

Holding the views he did, it is no matter for wonder that the President should sometimes pay scant attention to etiquette in his dealings with the Ambassadors in Washington. One of them said :

"Your President thinks nothing of sending for us at any hour of the day or night. It is not usual that the personal representative of a Sovereign should be 'sent for,' but we waive that and go. Once at the White House he says to us whatever comes into his head. We are lectured, chided for our own faults or those of our Governments, told to behave better in future, and so dismissed. We do not take offence. We recognize the good intentions of the President. We know that he cannot always control his impulses or confine his apostolic mission to purely domestic affairs. 
But we do not think it is a good way of doing business nor one that tends to smooth away diplomatic differences."

But that was not the limit of the President's diplomatic activities. It was no secret in Washington that the recall of Sir Mortimer Durand, British Ambassador from 1903 to 1906 , was due, directly or indirectly, to the President's dislike of him and to his expressed opinion that Sir Mortimer "was not a man with whom you could do business." There were other complaints which need not be dwelt on. Yet Sir Mortimer had had a distinguished career in India where he had been Foreign Secretary for ten years; had been Minister to Persia for six years and Ambassador to Spain for three years. When his proposed appointment to Washington had been made known, it was welcomed by the President. He was a very loyal, able, honourable man. It may be true that his abilities were not of the kind best suited to Washington; always a difficult post. It is certainly true that the Ambassador and the President were not sympathetic to each other. Again I am sure the President thought himself "absolutely wise and absolutely right," and had reason for thinking that Anglo-American interests and a general good understanding between England and the United States would thrive better with another tenant for the Embassy in Connecticut Avenue. If a fine career had to be ruined for reasons of State, or from a strain of impatience in the President, it does not follow that any censure need be pronounced on Sir Mortimer Durand. 


\section{IV}

HIS INTERVENTION BETWEEN RUSSIA AND JAPAN

Much has been said about President Roosevelt's intervention in the Russo-Japanese War and his success in securing an agreement between Russia and Japan at Portsmouth. For his untiring efforts and complete devotion to the cause of peace no praise could be too high; nor for his ingenuity and energy in bringing the two Powers together in Conference. Whether a Treaty of Peace might not have been made elsewhere and on the same or similar terms, without his intervention, is perhaps an unprofitable subject of speculation. I was in Washington when he entered upon his campaign of persuasion. The President's first notion was to receive the Plenipotentiaries of the two Powers in Washington and let them negotiate there. When it was suggested to him that Washington in August could hardly be depended on for the degree of coolness desirable in a difficult discussion, he seemed surprised and said :

"So far as I am concerned, I don't care whether I have to do my work on the Congo or at the North Pole."

He did, however, admit that others might be less careless about climate than he was, and that the humidity and heat together might make Washington an unsuitable place of meeting. Why Portsmouth was chosen I never knew. It had a variable climate and was often very hot and better suited for the mosquitoes, which held a conference of their own in great numbers, than for diplomatists. It was uncomfortable in many ways and the distance from 


\section{MR. THEODORE ROOSEVELT 36I}

the hall where the Japanese and Russians met to the hotel made the difficult work of the journalists more difficult still. Few places combined so many disadvantages. Of the one hundred and twenty journalists who were there for the Conference, many were foreigners; Russian, Japanese, English, French, German, and so on. I am not sure whether the President, who remained, not in Washington but at Oyster Bay, ought to be reckoned a journalist or not. He certainly supplies the Press of the world with a great deal of copy.

Having been ordered from England, whither I had gone for a holiday, to Portsmouth, I crossed the Atlantic with an English colleague on a North German Lloyd ship, on which Count Witte, the head of the Russian Embassy, was a passenger. Then and at Portsmouth and on the return voyage I saw much of Count Witte, and shall have something to say of him presently. My colleague was Sir Donald Mackenzie Wallace, formerly Foreign Editor of $\mathcal{T}$ be $\mathcal{T}$ ines. I wrote from New York to the President, asking leave to bring Sir Donald to see him, and the President named a day. The President's Secretary, Mr. Loeb, who has since been Collector of the Port of New York with a flaming sword in his hand, telegraphed us to come by a morning train to Oyster Bay and present ourselves at 3.30 p.m. at Sagamore Hill. As this involved a long wait in the village I asked whether we might not be received at four o'clock, for which there was a convenient train. But Mr. Loeb was inflexible, and even when I suggested to him that an Englishman of some distinction might not like to be kept waiting for hours in a little Long Island town, sent a "No" more peremptory than before. Even as Secretary he had his flaming sword ready for all comers. 
I knew that Count Witte was to lunch with the President that day, and that his audience was likely to last till later than half-past three. Mr. Loeb knew it too. The President, I assume, knew nothing of his Secretary's arbitrary ways. We had, at any rate, to choose between doing as we were told by Mr. Loeb and giving up the visit; and though Wallace and I both thought we were being rather rudely treated, we went. After some hours in the village we drove to Sagamore Hill, arrived at 3.30 , waited till 4.30 , saw Count Witte depart, and were admitted. Wallace, long a courtier and regarding the customs of royalty as holding good with the President, had insisted we should go in frock-coats and tall hats, and we did, much to the entertainment of the village. Count Witte was content with the travelling suit he had worn on the steamship and a battered shapeless straw hat. Autre pays, autres mours.

Since my former visit to Oyster Bay the house had been enlarged, and the President now occupied as his reception-room a large library-parlour on the ground floor. He talked to us rather freely about the Conference but said little that can be quoted even now. To Sir Donald he was cordial enough to make it plain he knew nothing about Mr. Loeb's discourtesies, and the Englishman brought away an agreeable impression of the President. To us, as to others, he said that when Japan and Russia had agreed to meet at Porstmouth he considered his work done. He had no intention of taking part in the proceedings- " no more to do with them than you have, nor so much." $\mathrm{He}$ hoped for the best but was not over-confident.

"I have brought them to a cool spring. It remains to be seen whether they will drink of it or not."

We all know that he changed his mind later and 
that his intervention at Portsmouth, at Tokio, and at St. Petersburg was frequent, energetic, and in a sense successful. As I am not writing a history of the Conference I confine myself here to the President's share in the Portsmouth proceedings. Preserving an appearance of impartiality and being, so far as the machinery of the Conference was concerned, really impartial in the beginning, he found himself, as he thought, compelled by circumstances unforeseen and undesired to take a hand in the game. He was, as both Japanese and Russians knew, Japanese in his sympathies. When Count Komura, the chief of the Japanese Plenipotentiaries, laid upon the table his demand upon Russia for a war indemnity of $\$ 600,000,000$, the President thought it ought to be paid. For the sake of clearness I omit all reference to other demands. It was upon this that the success or failure of the Conference depended.

When Russia refused to pay this enormous sum the President at first took the refusal as a piece of diplomacy. He thought Russia was holding out for better terms. He little guessed that Russia's answer to Japan's demand had been settled before Count Witte left St. Petersburg. He did not know-how could he? -that Count Witte had accepted his appointment as Plenipotentiary only on the condition that in no circumstances should he be required to assent to an indemnity. He thought it possible to bring pressure on Count Witte and his colleagues. He believed Japan would persist, as he thought she had a right to persist, in the exaction of these $\$ 600,000,000$, and that if they were not paid the Conference would break up and the war be renewed.

Hence his memorable attempt to induce the Emperor of Russia to give way. In his zeal the Presi- 


\section{ANGLO-AMERICAN MEMORIES}

dent had long since forgotten that he was not going to try to make the two Powers drink of the cool spring near which he had brought them. He kept the wires between Oyster Bay and Portsmouth hot, and presently the cable to St. Petersburg was heated seven times hotter. He instructed " his" Ambassador, Mr. Meyer, to ask an audience of the Emperor and to urge upon him that he should surrender to this Japanese demand. Mr. Meyer was to lay before the Emperor the reasons of the President for his yielding. The Emperor received the President's Ambassador, listened to him, and finally told him that a formal answer would be sent him by the Foreign Office. It came as a document of five hundred words to go by cable, and cabled it was to Oyster Bay. The five hundred words could all be condensed into a monosyllable: "No."

The President, naturally, was dissatisfied. $\mathrm{He}$ directed his Ambassador to see the Emperor again and renew his appeal. Mr. Meyer did as he was told and again the answer, much briefer than at first, was a refusal. The President-it is all but incredible yet true-sent Mr. Meyer a third time to the Emperor, and a third time the refusal was given; this third time with a peremptory brevity which even the President understood to be final. When Count Witte described to me what had taken place, he added:

"I do not think His Imperial Majesty, my Master, is in the habit of being asked three times whether he means what he says."

By this time the President was alarmed, and with good reason. A great change had occurred. When the two Embassies arrived in the United States, public opinion, beyond all doubt, was on the side of Japan. Before a fortnight had passed it veered about and became largely Russian. I will explain why later. 
Now it is only necessary to say that Count Witte had shown himself open-minded to the Press and had stated to the American journalists day by day the Russian case with consummate skill. The Japanese held aloof. Count Komura saw no journalist. Baron Takahira, having been Minister at Washington and better understanding American ways, was nevertheless forced to be silent. So with the Russian arguments and facts daily spread before them and nothing or almost nothing from Japan, the American people were naturally and inevitably influenced by what they read; and began to believe that the Russians must be in the right.

Now no man ever read more quickly and surely the minds of the American people than did $\mathrm{Mr}$. Roosevelt. He saw what was happening. He became anxious about his Conference; for his Conference it was. And when once he became convinced that Russia would never pay the $\$ 600,000,000$ he executed a complete volte-face and told the astonished Japanese whose demand he had vigorously supported that the demand must be withdrawn. He cabled Tokio as he had cabled St. Petersburg, only in an opposite sense. $\mathrm{He}$ warned Tokio and the Japanese Plenipotentiaries alike that they had alienated in a great measure the goodwill of the American nation, and that the only way to recover it was to renounce their claim for an indemnity. He told them of his own knowledge that whether they renounced it or not they never could get the money, for Russia never would pay it. And he prevailed. The Japanese withdrew their demand, peace was made, the President's Conference, which more than once had been on the point of breaking up, came to an agrecment, and the world breathed freely again. 


\section{ANGLO-AMERICAN MEMORIES}

With what feelings towards Mr. Roosevelt the Japanese departed from Portsmouth I dare not conjecture. He had forced them to act wisely, and they probably knew that their decision was wise if only because it was inevitable. But no man likes to be forced to be wise. The Japanese, if the truth may be told, had arrived at Portsmouth in an arrogant mood. They left it in a chastened mood. Victors in a great war, they had not been victors in the Conference. They had been outgeneralled by Count Witte. They had been forced to abandon their claim for a war indemnity; money which they had regarded as already in their pockets. Their prestige had suffered a cruel blow. Their popularity in America was grievously impaired. For all this they held the President responsible. For some part of it he undoubtedly was responsible. We remain on good terms with Japan ; for reasons of self-interest on both sides. But if you ask American travellers whether Americans are popular in Tokio and throughout Japan, you may be told that the Japanese are anything but grateful for the part we played at Portsmouth, and that they are not likely soon to forget what share President Roosevelt had in their humiliation.

\section{V}

HIS INTERVENTION BETWEEN ENGLAND AND EGYPT

As Mr. Roosevelt seems still * inclined to emerge at intervals from his well-earned retirement, it may not be too late to say yet another word about this eminent ex-President. From no account of him ought the impression he made on European opinion, and especially

* November, I91 I. 
on English opinion, to be omitted. Many narratives went by cable. I shall try to confine myself to memories not likely to have reached America in that way.

I will come at once to the critical moment when Mr. Roosevelt thought it his duty to admonish the English Government and people concerning their duty to Egypt, and to England in Egypt. He had been in Egypt, on his return from his adventures as naturalist to the Smithsonian Institution, long enough to form a just conception of the position of the English and of the changes, in administrative efficiency if not in policy, which had taken place since Lord Cromer had retired and Sir Eldon Gorst had been in nominal command. I say nominal because it seems clear that the relaxation of English authority under Sir Eldon Gorst was the direct result of instructions from the home Government; a Government saturated with Radical notions of the Rights of Man, notions to be put in force regardless of race, regardless of political conditions, regardless of expediency, regardless of Imperial interests and necessities. Mr. Roosevelt himself holds, or has held, views of human brotherhood not less visionary than those for some time past prevailing at Westminster. But he did, at any rate, consider that the business of a Government was to govern, and no President ever acted on that belief with more energy than President Roosevelt did. And he saw clearly that in Egypt the Government was ceasing to govern, and that Radical theories were endangering the supremacy and the beneficent influence of England in Egypt. Seeing this, and having formed a strong opinion about it, he could not, I suppose, help expressing it; and he did express it at the Guildhall in a way which astonished Englishmen. He said to them, almost in so many words : 
"You must either govern Egypt or get out."

He was at that moment the guest of England or, if not strictly of England, of the City of London where he was speaking. No doubt he knew there is such a thing as a social code which forbids a guest to undertake to regulate the affairs of his host's household. But what are social codes to a missionary spirit? What obligations of courtesy are binding on the vicegerent of the Almighty ?. Even an Old Testament or a New Testament evangelist would disregard them, much more an American ex-President with a message from on high. It was not with him a matter of choice. He had to speak, and speak he did.

In a way it was a useful deliverance. It woke up England, always disposed to be sluggish in far-off Imperial affairs till a cannon-shot breaks her slumbers. It found an echo in that great body of convinced but for the most part silent Imperialists to whom the Empire is a living thing. It startled and even impressed the Radicals themselves who could hardly understand how an American Republican should be preaching an Imperial gospel. The English Press reflected these impressions and through the English Press they found their way, no doubt, into the American Press. And there were, I have heard, multitudes of Americans who felt a patriotic pleasure in this spectacle of a distinguished American hitting out straight from the shoulder at his English friends.

Not for worlds would I say a word to disturb this patriotic ecstasy. But there is, in fact, a very considerable difference between the methods of the English Press and the American Press in dealing with a matter so complicated as this. We should have said pretty nearly what we thought. If an Englishman had stood up at a Chamber of Commerce dinner in 
New York and told us we were letting things go to the devil in the Philippines-at a time when they were going to the devil-we should have resented it, Mr. Roosevelt first of all, and told him it was no business of his, and that an exhortation by an Englishman to Americans about American affairs, and a criticism on our conduct of them, was an impertinence; as it would have been.

Not so the English papers. They dealt gently with Mr. Roosevelt. Those who agreed with him about Egypt said they agreed, and some of them said it was well they should be reminded of their duty; though they did not say by a foreigner. They even took a humorous view of this incident. They thought it natural enough that Mr. Roosevelt's apostolic fervour should blind him to considerations of time and place; though they delicately hinted that it might be possible to be apostolic and polite at the same time.

Far otherwise was the tone in private life. If in print the English put decorum first, in private they speak out. They, in fact, said in private very much what we should have said in print. The men who agreed with Mr. Roosevelt about Egypt said the hardest things of him. I used to hear their most explosive criticisms for the most part at secondhand; since even in their wrath they were mindful of the civilities they thought Mr. Roosevelt had violated, and would not condemn him to an American. But American or not, you could not live here without becoming aware of the state of feeling. To Mr. Roosevelt himself they made, I think, only smooth speeches. Not in the presence of any American would they talk about "Yankee impudence." But among themselves they appear to have used even stronger phrases. 
A public luncheon or dinner, moreover, is neutral ground unless avowedly political. In the presence of Ministers or of Ministers' friends, no Englishman would have attacked Ministers or their policy. I know the ice is getting thin, but I will venture to say that such an attack as Mr. Littleton made on the President and his trust policy at a dinner where the President was the guest of honour would have been impossible in England. It would have been thought unmannerly, inconsistent with that political and social decency expected of public men. Mr. Roosevelt's offence was not of the same kind or degree, but it was nevertheless according to English ideas an offence. And, in the long run, it injured the cause he meant to support. The injury was not, we may hope, permanent. Ministers have done what they could to remedy their tolerance of the Nationalist movement in Egypt. They have put Lord Kitchener in charge; and Lord Kitchener's name alone was sufficient to restore order.

Apart from this Egyptian business, Mr. Roosevelt left none but pleasant memories behind him. He came among the English with a renown greater than that of any American they had seen, General Grant excepted. He left them with his renown undiminished. They recognized his great qualities. They saw in him a man; and that is what they like best. His frankness appealed to them. If it amused them to find him so very glad to meet so many total strangers, that did him no harm. They thought him sincere, though exuberant; with an essential sincerity of character. Possibly they knew he has not a drop of English blood in his veins and is rather fond of saying so, but they none the less recognized in him a kinship of soul and of character. He was a force, and to them a sympa- 
thetic force. They like a man who has done things; who has played a great part greatly. They knew he had been a strong President, and sometimes arbitrary, and liked him none the worse for that. With this nation of sportsmen his exploits in Africa had set the seal to his fame. They expressed it in their moderate colloquial English way :

"There can't be much the matter with a man who goes for big game."

They thought it graceful and fitting that he should have wished to be Special Ambassador at the funeral of King Edward; a King whose greatness looms larger year by year. His appearance at that ceremony was not what it might have been. He was one of three in a royal closed carriage. A European newspaper told us that he himself did not like it, saying :

"I put myself in the hands of the authorities and was ready to do what they liked, but I did not expect to ride with a Dago and a Chinkie."

I quote it only to remark that, widely circulated as the speech was, it cannot have been uttered by Mr. Roosevelt. His companions were the French Minister of Foreign Affairs and the Persian Minister. The English would have liked to see the ex-President by himself on horseback, perhaps in the uniform of a Rough Rider; not in a tall hat and evening clothes. But that mattered little. What mattered was his presence and all that it signified. The presence of his daughter, Mrs. Longworth, added to the content of the English who had admired and liked the Alice Roosevelt of earlier days, and paid homage to her beauty and her delightful originalities, and to all the attractions they loved the better because they were American and not English.

Of Mr. Roosevelt's political misadventures since his 
return, I don't think the English knew much until he suddenly appeared as an opponent of the President's Arbitration Treaties. There his attitude perplexes them. The fact of his opposition is better known than the grounds of it. The cable does not much concern itself with reasons. It gives results. But embittered phrases come to us from beneath the Atlantic. The Arbitration Treaties and the support of them are, says Mr. Roosevelt, a "hypocritical move against the interests of peace and against the honour and interests of the United States and civilization." In his magazine and in his letter to the Peace Dinner Committee, the words hypocrisy and hypocritical are used more than once. To whom do they apply? President Taft appears to be accused of hypocrisy because he did not submit to arbitration the issue between Russia and the United States touching the Treaty of 1832 , which he gave notice he would abrogate. President Taft replied civilly and conclusively that there could be no question of arbitration. He terminates the Treaty not because it has been violated but because it is obsolete. Under the Treaty when negotiated, the American theory and the Russian theory of expatriation were the same. They are no longer the same and therefore a new Treaty must be made. I should never apply to Mr. Roosevelt the language he uses to President 'Taft, whom he must in his sober moments know to be incapable of hypocrisy. Mr. Roosevelt is as sincere as he is intemperate. Let us admit, and regret, that he honestly believes it impossible to differ from him honestly.

The Arbitration Treaties are popular in England, and with all classes of English. Not an influential voice has been raised against them. They are believed to be popular in America, the Senate, of course, 
excepted; it being well understood that to that august but difficult body all treaties, as treaties, are objects of suspicion and hatred. The English do not understand party divisions or personal animosities in American politics. They cannot be expected to. I sometimes wonder whether we understand them ourselves. And so they ask in a dazed way why $\mathrm{Mr}$. Roosevelt should be so often in antagonism to the President whom he chose, so far as he could choose, to be his successor; who was the heir to his policy or policies; and who has carried steadily on, though by less violent methods, the work which Mr. Roosevelt began. To-day Europe regards Mr. Taft as a sagacious and great Chief Magistrate of the great American Republic. The censoriousness of $\mathcal{T}$ be Outlook has not diminished Mr. Taft's fame abroad. Has it at home? I impute no ill motive to his critic, nor does anybody here think Mr. Roosevelt moved by jealous envy of his successor. The only serious comment I have heard is that an energetic Executive is not necessarily an effective critic of policies or purposes in which he no longer has an active share.

\section{VI}

PERSONAL INCIDENTS-POLITICAL NIHILISMS

Mr. Roosevelt's English sympathies, of which our Irish friends and enemies sometimes complain, are I think of comparatively recent growth. His attitude during the Boer War was, to say the least, critical. His reception of Irish emissarics during his Presidency lacked no element of cordiality to the Irish, and sometimes provoked comment in England, where however incidents of that kind have been too frequent to cause 


\section{4 \\ ANGLO-AMERICAN MEMORIES}

surprise. The Englishman who is aware of them mutters something about the Irish vote in America, and turns a blind eye to the cable dispatches which record these singular manifestations of friendship to a friendly Government.

Nothing, indeed, is more characteristic of the Englishman than his indifference to proceedings of the kind Mr. Roosevelt and other Presidents before him have thought consistent with international comity. He knows little about them and cares less. A question may be asked in Parliament or in private. Somebody asked one the other day about Mr. Champ Clark and his schoolboy talk of annexing Canada. The new Under-Secretary for Foreign Affairs, Mr. Acland, answered with polite contempt that he did not suppose Mr. Champ Clark was to be taken seriously. Nor does it appear that his buffooneries disturb the good feeling happily existing in both countries. The cable, I suppose, must report them and the papers must print them, but not a ripple is left on the surface.

The Senate of the United States once refused to adopt a resolution expressing the regret of the American people at the death of Mr. John Bright, the best and most powerful friend the American people had in England in the days when they had few. Years afterward, upon some reference to it, Mr. Bright's son told me he had never heard of it and asked if it was true. Of President Roosevelt's coquetries with Mr. O'Connor and other Nationalist agents not much more notice was taken. One Englishman, a man as likely as anybody to be sensitive in such a matter, said :

"Well, O'Connor is an amusing devil and I suppose he amused Mr. Roosevelt."

The Boer sympathies of Mr. Roosevelt were de- 
veloped before he became President, and probably were never declared in such a way as to attract attention in England. For that was a subject on which even an Englishman had susceptibilities. Mr. Roosevelt's Dutch blood did not run in his veins for nothing. $\mathrm{He}$ probably thought of the Boers as Mr. Gladstone thought of the Confederates, "a people rightly struggling to be free" and to keep other people in slavery, since in the annals of slavery there is nothing more horrible than the cruelties of the Boers to the African natives. But, to quote Mr. Disraeli once more, a great deal has happened since then, and I pass from the subject. Nor do I mean to question the sincerity of Mr. Roosevelt's conversion. He has since proved his goodwill to England on some memorable occasions. Even his outburst in the Guildhall about Egypt was, in his own view, an expression of friendship.

The English, in any case, if they knew of Mr. Roosevelt's Boer partialities, bore no malice. When the exPresident started after big game in a part of Africa under English jurisdiction, the Governor of the province not only gave him all facilities, but a territory to himself ; from which, so long as Mr. Roosevelt was pursuing his game and his natural history researches, all other sportsmen were excluded; a stretch of the Governor's authority, perhaps, though sanctioned at home, but excellent evidence of good nature. This again contributed to swell his renown as a mighty hunter and to augment the cordiality of his reception in London. I believe Mr. Roosevelt thought London more friendly than all other European capitals; and it was from London that he carried with him, it may be, the extreme conception of his own power which led him to undertake that disastrous political campaign at home two months later. 
He was just as human after he became President as before; and just as much Roosevelt. His liking for "fun" was not less evident in the White House than in the Police Head-quarters in New York or the Executive Mansion at Albany. At one moment the ringing laugh of boyhood; at the next, all seriousness and firm purpose. It was just after one of these explosions of irrepressible good humour that I took up a new pattern of policeman's club lying on his desk, a thing of solid india-rubber or gutta-percha, and asked him whether he was going to adopt it for the police force. Instantly his face grew grave.

"No; it is too lethal."

I told him I had seen men drop dead from a blow with the clubs then in use. He said:

"No doubt; but the fewer the better."

Yet he would not shrink from strong measures. At the time of the great Pennsylvania strikes a notion spread among the trade unionists that the President was on their side and would not interfere to keep order, no matter to what violence they resorted. I said so to him. The lines of the jaw tightened, and he answered:

"If they think I am going to tolerate mob law they will find out their mistake five minutes after they have begun."

There spoke the President we admired and trusted. Whatever else he might be, he was the inflexible guardian of public order. The Washington negroes, or some of them, a turbulent crew, misunderstood him in much the same way and thought him their champion for all purposes. A black burglar seized by the police as he was entering a house, shook his huge fist in their faces, saying: "That man up thar will look after me." "Up thar" was the White House. But he went comfortably to prison all the same. 
The history of Mr. Roosevelt's relations with the Senate would make a chapter, or a volume, invaluable for public use and for a just appreciation of that remarkable body and its oligarchical tendencies. While Vice-President and presiding officer of the Senate, he had seen this assembly of patriots at close quarters. Even then they showed a curious dislike or distrust of him, and thought it desirable to read him a lesson. As Vice-President he was an outsider, and the Senate prefers one of its own members to guide, or not to guide, its deliberations, when it gets a chance to choose. When Mr. Roosevelt arrived, new to these duties and with all sorts of laurels, municipal, military, and executive, the Senate, or some of the Senators, benevolently undertook to begin his education over again. The rules of this body are at best elastic, but certain rules and customs and traditions are rigid enough, and some of these the inexperienced young man who had been in Cuba "all alone," and had governed the seven millions of people who compose the State of New York, disregarded. He had a notion, not shared by the Senate, that rules were meant to facilitate business, and used them to that end. I don't say that a trap was laid for him but, however it happened, he found himself at odds with some of the Senate leaders, his rulings questioned, and precedents quoted against him. He gave way, but it may well enough be that, though the King forgot, or said he forgot, the grievances of the Dauphin, the President remembered the affront put on him as Vice-President.

I had sat one day for half an hour with the President in the Cabinet chamber, where at that time he gave audience or, if you like better, received visitors who had appointments. When I rose to go he said with a whimsical look in his cyes: 
"Do you know you have been keeping Senators waiting all this time, and they don't like waiting ?" And when I suggested that it was in his power, but not in mine, to make these great men dance attendance outside, he said:

"It is good for them. I am President, after all. But don't go. Sit on that sofa in the corner and hear what they have to say. It may amuse you."

"But it may not amuse them."

"Never you mind. When I think you ought to go I will tell you."

I did as I was bidden. The faces of the Senators who one after another came in were studies in surprise and some stronger feelings. The President received them as usual and as if nobody else was there, and talked, though they did not, with freedom. When they hesitated he said, "Oh, go on," and to the end enjoyed the "fun." Some of the Senators I knew and they me, but that did not seem to relieve the situation. There were others beside Senators, among them district political managers-bosses, in short-with candidates to urge for offices. The President listened to them, but when they had stated their case it presently appeared that he knew as much as they did about their districts and candidates and local affairs. He may have been coached beforehand, but there seemed no detail of local politics or men unknown to him. I thought of Gambetta, with a secret service spreading all over France. It was said of the great Frenchman that one reason of his supremacy was his mastery of affairs and his all-embracing knowledge. It might be said of Mr. Roosevelt.

Twice I saw the President in less august company. His barber came in and shaved him while he talked without ceasing. "It's the only time I can get," 
remarked Mr. Roosevelt. "I hope you don't mind." I did not mind. It was one trait the more.

Twice in his Police and Vice-Presidential days I met him in odd ways. Once was at the Oriental Hotel where Mr. Platt, then in the height of his power or not far from it, was staying. "I think we might call on Mr. Platt," said Mr. Roosevelt, and we did. We spent an hour with him, and this time he carried discretion so far as to leave politics wholly aside. During most of the visit he discoursed to Mr. Platt and me on early Macedonian history, with elucidations of the policy and doctrines of Antigonus, Antipater, and I know not who else. Mr. Platt's face meanwhile was a mask. Much later we both dined with Senator Depew in Washington, who had as guest Mr. Frederic Harrison from London whose knowledge of ancient history was certainly much greater than Mr. Platt's. To Mr. Harrison also Mr. Roosevelt enlarged after dinner on this same topic of Macedonia. He might have been a college professor expounding history to his pupils. Mr. Harrison, who has always thought himself better fitted to teach than to learn, listened with politeness, not without surprise, and abstained from all comment on the lecturer's views. He recovered himself later in England, upon the appearance of a friendly review of Mr. Roosevelt's Cromwell by Lord Morley; asking Morley, "How could you praise such a book as that?" But I imagine most of us would sooner accept Morley's opinion than Harrison's.

It may not be an auspicious moment to revive the memory of the President's hospitality to Mr. Booker Washington, nor do I know whether the true story of that incident has been told. Nothing could be simpler. The President had seen Mr. Booker Washington in 
the morning, and they had discussed together $\mathrm{Mr}$. Washington's plans for the education and other improvement of the negro. They could not finish, and in order to go on with the talk the President said to Mr. Booker Washington: "Come back to dinner and we can take the matter up again." Said the President:

"I asked him just as I asked Mr. Powderly the other day in the same circumstances; in both cases with no other thought than to dispatch as quickly as possible the business we had in hand."

Whoever knows Mr. Roosevelt will see at once how natural, and of course true, is this explanation. It was thus and not otherwise that the invitation was given. Nobody was more astonished than the President that an incident so trivial in itself, or which he thought trivial, should have roused the whole South to fury, and have led the ex-Confederates or their children to believe that he meant to establish a social equality between white and black; which surely never entered his mind.

I have referred before to the meeting of the President and of Mr. Oliver Borthwick, the young Englishman whose achievements and charm of character delighted everybody and delighted Mr. Roosevelt. When I told him how much the President had relished his talk at lunch, Borthwick said:

"That's awfully good of him, but you know it was he who did the talking."

Similar stories are known of Mr. Gladstone and Sir Arthur Godley, and of Mr. Gladstone and Lord Edmund Fitzmaurice when he had been appointed Commissioner to the Balkans. Fitzmaurice told me of his own experience, so that two of the three anecdotes are certainly true. Why should they not be ? 
Nobody ever wished to interrupt either Mr. Gladstone or Mr. Roosevelt.

Yet to interrupt Mr. Roosevelt might have been, at certain moments, to do him a service. One such moment was during his speech at Osawatomie when he denounced the Supreme Court of the United States because some of its decisions were not in accord with the trend of modern opinion; in other words, with Mr. Roosevelt's opinions. Still more grotesque was his conception of that great tribunal when he declared that in its decisions in the Standard Oil and Tobacco Trust cases it had "legislated." Had that been true it would have discredited the Court, but Mr. Roosevelt said the Court was right to legislate. He went further still. He proclaimed it the duty of the Supreme Court to legislate whenever Congress should omit to pass such laws as ought to be passed in the interests of the Republic. If Congress did not do what Mr. Roosevelt thought it ought to do, then the Supreme Court must usurp the legislative authority of Congress. There is no other remedy, said Mr. Roosevelt in his impetuous way; forgetting two things. Forgetting, first, that it is not for any one American, however eminent, to determine what the public good imperatively demands, but for the whole American people. Forgetting, secondly, that the people has the remedy in its own hands, and the power to elect another Congress to do what this Congress neglects. Forgetting also that the Constitution divides the powers of the Government into legislative, executive, and judicial, and that for any branch to assume the functions of any other is an act of usurpation.

Still more recently he has been urging that there should be some sort of appeal from the Supreme Court to the people. Certain decisions of the Court are to 


\section{ANGLO-AMERICAN MEMORIES}

be subject, apparently, to a referendum. The judicial powers which the Constitution has placed in the hands of the Court are to be, in the last resort, annulled by popular vote. The Oklahoma doctrine of "recall"the power of removing unpopular judges by a plebiscite-is to be applied, not to the judges but to their considered and final judgments. Jefferson in his wildest exaltation of Democracy never touched the confines of a madness like this.

For many years Mr. Roosevelt has been undermining the reverence of the American people for law and for the Constitution which is our fundamental law. He would substitute-he has at times substituted -for law his own convictions; forgetting again the memorable declaration that a Constitution was framed " to the end that this may be a government of laws and not of men." If respect for the Constitution goes, and for the Supreme Court as the authorized interpreter of the Constitution and of the laws, everything goes. The foundations of the American Republic will have disappeared.

Mr. Roosevelt to-day is one of the forces that make for their destruction, and the doctrines he preaches are the doctrines of Anarchy. 


\section{CHAPTER XXX}

COUNT WITTE AND IVHAT HE DID AT PORTSMOU'TH

\section{I}

SINCE 1905 Count Witte has withdrawn from public life and his name is not often mentioned. But forgotten he can never be, nor can history ever be silent concerning the man who won a diplomatic victory for his country at Portsmouth after her defeat on the battlefields of Asia. Count Witte was the real hero of the Portsmouth Conference. By his adroitness the Conference was kept alive when but for him it must have collapsed. By his courage, his unbending resolve, his masterly and masterful diplomacy, was the triumph for Russia achieved. He has had none too much recognition; reason enough why he should have a little more and why some part of the truth hitherto withheld should now be stated.

When I left London, reluctantly enough, for Portsmouth, I took passage on the Kaiser Wilhelm der Grosse because Count Witte was known to be going by that ship. We sailed from Southampton Wednesday noon, expecting to pick up the Russian at Cherbourg by six o'clock that evening. But there was delay and the ship anchored at the Needles. Nobody would tell us why, though finally an officer assured us we should start at three o'clock next morning. Upon this I assumed that there was an accident to the machinery and that it would take all these hours to 


\section{ANGLO-AMERICAN MEMORIES}

make repairs. Not on any other theory could the fixing of a precise hour for restarting be explained. At seven o'clock we dined. The North German, by which I mean especially Prussian, cuisine is the most highly coloured in Europe, and whether you dine at a big hotel in Berlin or on a North German Lloyd ship the prismatic hues of the dishes are much the same. The food is various, abundant, and well suited, I doubt not, to the German taste.

After dinner I went on deck, to find the ship still anchored at the Needles and a brilliant starlit evening. Presently I met a high officer of the ship and asked him how the machinery repairs were getting on. With a surprised air he answered :

"The machinery is all right."

"Then what are we waiting for?"

"We can't move till the fog lifts."

I looked at him and then at the sea and sky. Above and below it was clear as daylight for as many miles as the eye could reach. But my friend said:

"Oh, it's the fog in the Channel that keeps us."

And as I suppose I still looked puzzled, he added:

"Don't you know that the Channel is the great highway of the world's trade from East to West and from West to East, and that to cross the line of this traffic, as we must, from North to South is a dangerous business ?"

What a remark to make to a passenger! But again he said:

"If you will come to my cabin I will show you a thick pile of telegrams all reporting dense fog all over the Channel."

I had it on my lips to say that I thought a British captain would at least have gone on till he found the fog. But I did not; nor did I look at the fog tele- 
grams, but thanked him and said good night and sat down in my deck chair to meditate on the different methods of seamanship prevailing in German and British ships. It was long past midnight when I turned in; the big ship still anchored and myriads of stars still mirrored in the smooth waters about us. What time we finally got away I never knew, but the ship was under full steam at breakfast, and we reached Cherbourg, a six hours' passage, between two and three o'clock that Thursday afternoon; some twenty-seven hours out from Southampton. A tender met us in the harbour with the passengers who had left Paris Wednesday morning expecting to embark that same afternoon. The hotels of Cherbourg could put up but a fraction of the whole number. The rest had spent the night in the railway station or in the streets, and looked it. Some of them complained bitterly that they had not been warned of the delay before leaving Paris. But the French railway authorities look with no loving eye on German ships, and, though I believe they have now come to some sort of terms, the stories of inconvenience and even hardships were for years many.

Count Witte, like his fellow-passengers on the tender, looked the worse for wear. He was easily distinguishable by his great height and Slav face. His wife was with him but here they parted and he came on board the Kaiser by himself, the people on the tender and the ship saluting him. The Captain and other officers were at the gangway to receive him, and I imagine they told him they had been delayed by fog. When he asked me about it some days later I did not then like to repeat the conversation as above given and I said that, so far as I could make out, the German word for fog and starlight was the same. He himself spoke German indifferently well, but I think

$2 \mathrm{C}$ 
he did not take my suggestion too literally. A Russian of the Witte pattern is a quick-witted person.

Sir Donald Wallace, my colleague on $\mathcal{T}$ be $\mathcal{T}_{\text {imes, }}$ had met Count Witte in Russia and proposed to introduce me. But whereas Wallace's sympathies were known to be Russian, mine, if I had any, and I think I then had, were Japanese, and this I knew Count Witte had been told. I preferred, therefore, to wait for a signal, and for two days or perhaps three the ceremony was postponed. On the third morning Wallace said he had arranged it, and I was taken up to Count Witte and "presented." $\mathrm{He}$ was sitting far back in his chair, out of which he slowly uncoiled his long body, climbed to his feet and, with some perceptible hesitation, held out his hand. His eyes looked distrustfully, almost fiercely, into mine. The penetrating glance was one you would not forget when once you had endured it. The whole force of the man was concentrated in his eyes and in the great arched forehead above them. The other features were irregular, the nose " aquiline with the curve reversed"; the mouth loose-lipped. Huge as his body was, it gave you no great impression of power. The frame was nowhere closely knit; the long arms seemed double-jointed, and he carried himself carelessly, whether standing or walking.

I was to see Count Witte almost daily for the next six weeks, but the first impression held good all through. You could not mistake him for anything but an extraordinary being. He was born at Tiflis but describes himself as, on his father's side, a descendant of Dutch emigrants to Russia. No doubt but, as usual, it is to the mother we must look for a male child's essential characteristics, and his mother was not Dutch, but of the Caucasus. He had an almost childlike openness of 
manner and behind it an impenetrable reserve. You never were sure that you had got inside his mind. He had the true Oriental subtlety. Tartar or Slav or whatever else, all Russians have this Oriental stamp upon them; this aloofness from the Western world. I knew Count Witte's history, knew him as a man of the people who had grown from nothing, highly educated but as a boy a railway servant like Carnegie; and in him a giant business capacity, also like Carnegie. $\mathrm{He}$ rose high in railway management, then passed into the Government service, came to be Railway Director in the Ministry of Finance, then Minister and remained Minister for ten years. During that time he restored the railway and other finances of Russia, put finance on a gold coinage basis, created a State monopoly in, I think, spirits and tobacco, at any rate in something; restored her credit and reorganized the service. A great piece of work by a great Minister, and all in ten years.

Everybody on the ship of course knew Count Witte by sight, and I suppose a few persons knew that I was The Times representative and had a curiosity to see the meeting between the two. A little group collected. Said Count Witte:

"You represent The Times in Washington."

"Yes."

"Your dispatches, or some of them, have not been friendly to Russia."

"If you would say they had been friendly to Japan, I should agree. But American friendship to Russia is traditional and older than to Japan."

This olive branch he accepted, and looking at the company surrounding us said:

" Don't you think we could talk better if we walked the deck a little?" 
Thus began the first of many, many interesting and often engrossing conversations. He started warily enough; by no means putting off all his suspicions at once. He sought neutral ground. But before the day was over he had so far relaxed as to say:

"You are going to Portsmouth and you will want to know what happens. Whenever you will come to see me I shall be happy to tell you what I can."

He kept his word. So long as we were on the Atlantic he talked mostly of other subjects. He was bent on finding out how matters stood in the United States, and what Americans thought about the relations between Russia and Japan. He was curious concerning President Roosevelt, and hearing that I had long known him said:

"I don't wish to ask you any questions you are not quite willing to answer, but it is your President who has set this Conference going, and anything you will tell me about him will be of great interest. He has brought us a long way, but the Japanese have had a longer journey still, so we don't complain."

It was easy to see what a burden of anxiety he bore. It could not be otherwise. He did not complain of that either. It was inevitable. The fortune of peace or war, perhaps the whole future of Russia, lay in his hand. Yet he bore himself light-heartedly enough. He gave all his thoughts to the subject of the moment, whatever it was, and put his mind to that. When once it was understood that we were not to discuss the work of the Conference, the rest was easy.

Or easy with one exception. All our talk was in French. Count Witte had no English and I had no Russian. French he spoke fluently, inaccurately, with a royal contempt for grammar and genders, and with an accent which he may have brought with him from 
the Caucasus. The words tumbled over each other out of his mouth. The Frenchmen themselves hardly speak their own language with such rapidity. To add to the difficulty a cigarette was always in his lips. At Portsmouth it was worse, for there we walked up and down for ever on a wooden piazza, and the noise of two pairs of feet was one confusion the more. Sometimes I asked him to repeat a sentence. He did it at first suspiciously, as if he thought I had another motive, but when I told him I could not always understand, he laughed and said:

"True, it's not my language nor yours."

He had, moreover, the diplomatist's habit of generalities. He liked being a little vague when handling a delicate matter. Yet for his own purposes he had a sufficient mastery of this tongue which was not his own, and you could not afford to miss a word. Often the balance of his thought and the expression of it depended on a shade. But he thought so clearly and the force of his mind was such that if he had spoken Choctaw his meaning would somehow have found its way to your mind.

\section{II}

What had first impressed me in my talks with Count Witte on the Kaiser Wilhelm der Grosse was his cheerfulness. He was on his way to make a Treaty of Peace at Portsmouth with a Power which had beaten Russia to a standstill and, as most people thought, to accept such terms as Japan might see fit to impose. But he himself had never the air of a beaten man. I understood that the President at Oyster Bay had been not a little surprised to find him serene and apparently confident. Certainly the American public, prone at 
that time to believe that its President's will must prevail, had looked upon the conclusion of the Portsmouth negotiations as foregone. There would be discussions, of course. There might be concessions by Japan on minor points. But the main issues had been settled on the battlefields of Asia, and Portsmouth was only to register the results.

When we arrived at Portsmouth the one hundred and twenty journalists were nearly all of that mind, and we were all so many barometers whose minds were made up for us by the atmosphere we breathed. All, or almost all, the first dispatches from this queer little seaport watering-place were written in Japanese. If the language was not Japanese the spirit was. The American Press was Japanese, and of course the English since England was the ally of Japan, and the Treaty between them, already ten years old, had profoundly modified the politics of the East. Within a few days a change came. The atmosphere of Portsmouth had changed. The barometers no longer stood at set fair or at what the Japanese considered set fair. The American Press itself had changed.

I cannot say whether Count Witte went there with the fixed purpose of converting journalists and Press to his side. He was, at any rate, a man with an extraordinary quickness and flexibility of mind. He understood the situation as nobody else understood it. $\mathrm{He}$ understood the American people, and how they were to be influenced. When he was appointed Plenipotentiary men said of him:

"Yes, an able man, but no diplomatist. He has had no diplomatic experience."

They said of Count Komura, the Japanese Plenipotentiary:

"Yes, a great diplomatist with great diplomatic 
experience. Count Witte will be a child in his hands."

These opinions had to be revised almost at once; and for two reasons. It was seen that the Russian was using such means of conciliating American opinion as lay ready to his hands, and that the Japanese were not. The journalists found themselves welcome at the Russian head-quarters, and the doors shut in their faces by the Japanese. Then, though the proceedings at the Conference were secret and no journalist admitted, it became known as soon as the formalities were over that the Russians did not seem to be in a yielding mood. Now a journalist in search of news is rather apt to think nothing but news matters, and his personal good will-for even journalists are human-goes out to the man who gives him what news he can, and not to the man who withholds what he might give. The conditions of secrecy were just as scrupulously observed by the Russians as by the Japanese, yet within a week the Russian view had been put before the world in such a way as to unsettle American sympathies with Japan.

Count Witte might not be able to say much about the proceedings of the Conference, and did not. But he talked freely on matters of common knowledge. He stated the Russian case. The trained journalists who found him so ready to receive them were equally ready to present his statements to their distant publics, if only because they had little else to present. Count Witte was far too shrewd to argue, or to let it be seen that he was making an appeal to America and to the world. He let fall a sentence as if it had slipped unawares from his mouth. It might be a fact or a suggestion. It might touch the business of the Conference or it might be a reminiscence of the past. He 
offered it to you as if for want of something better, with a regret that the obligations of secrecy forbade him to tell you what had happened that day at the Conference. The journalist, or group of journalists, to whom he said it caught at it eagerly, spread it on the wires, perhaps a little fuller in form than when uttered, and next morning some millions of people in two hemispheres were reading it.

Presently it came back to us in print, and in print it seemed a more pregnant saying than it had seemed when hurriedly written out for the telegraph or the cable. Some of these dispatches to European journals were sent in duplicate to American journals, so that they were all soon back again in Portsmouth. I omit, of course, from this account the dispatches to the Japanese papers. They were wholly of Japanese origin, or the Japanese correspondents supposed they were. Whether even the little brown brothers entirely escaped the influence of the atmosphere in which they lived may be doubtful. It was, I believe, thought in Tokio and other Japanese towns that the news supplied to them was meagre, as it was.

After this process had gone on day by day for a week or more I took a single series of dispatches and read them all over. I confess I was astonished as I saw how much ground they covered and on what broad lines the Russian case had been built up. I began to understand what an artist Count Witte was, and how the separate touches of his brush grouped themselves even in this early stage into something like a picture. The use he made of his material was consummately skilful. Then I began to consider what the effect of all this must be on the American mind; or, for that matter, on the English. I compared my own daily impressions of what Count Witte had said 
to me with the sum of all these impressions when taken together, and I became aware how far we had all travelled on the road which the Russian had opened before us. It was not my fault nor anybody's fault, but the road led undoubtedly by many a winding path and through a pleasing landscape toward the Russian camp. I repeat, no other road was open to us, no map was at our disposal except that provided by Count Witte, but the result was the same. We had all been composing for our readers a guide book to Russia.

Thinking it all over, I resolved to set forth this view to Baron Takahira. To ask to see Count Komura, the chief Japanese Plenipotentiary, was useless. I had already asked and had been given to understand, as others were, that whatever Count Komura wished to be known would be made known by Baron Takahira. The daily bulletins issued by the Japanese and read aloud to all comers in the entrance hall of the hotel conveyed no real information, and were meant to convey none. Such conversations as I had had with Baron Takahira were not much more enlightening. I had known in times past, often in very critical times, a certain number of Ambassadors and Foreign Ministers. Not one among them all had been so closely boutonné as these Asiatics. The Asiatics had adopted, for reasons sufficient to them, a policy of silence, and from this they were resolved not to depart. But I thought the moment had come to make a final attempt, and I made it.

Baron Takahira received me, as usual, with a grave politeness which did not altogether conceal a certain hardness of temper, or even a sense of embarrassment arising out of the rôle he was obliged to play. He said at once : 
"I am afraid I can tell you little or nothing beyond what I have said already."

You can never be sure of surprising a diplomatist by the most unexpected statement, still less can you expect him to show that he is surprised. But I meant to try, and I said :

"Excellency, I come to you, of course, as a journalist, but not wholly as a journalist, nor am I at this moment in search of news. I come as a journalist whom you have known to be, and who still is, full of good will to Japan. What I want to say to you is that I think the interests of Japan have been very gravely compromised within the last week, and that it is you and your chief who have compromised them."

For once I had succeeded in surprising this astute Oriental, and for one second he even showed that he was surprised. Then, with his usual inscrutable serenity, he asked me to explain what I meant. I explained as I have explained above; with less directness but not less plainly, and at far greater length. He listened patiently. I gave him facts, quoted dispatches, told him what I believed to be the general opinion of the journalists then present in Portsmouth, and laid before him extracts from editorial articles in important English and American papers. I thought then, and I still think, that this mass of evidence ought to have convinced him of the peril to which the Japanese policy was exposing the Japanese cause. To my mind it was conclusive. It proved that a change had been going on in the American mind, a change wholly unfavourable to Japan; that this change was due primarily to Count Witte's relations with the American Press, and to the refusal of the Japanese to make, in their own interest, a legitimate use of the columns open to them. I urged upon him that, though 
the mischief had gone far, it was not yet too late to stop it but soon would be, and I asked him to put the whole case before Count Komura. I did not expect nor ask Baron Takahira himself to do more than that.

I do not think I made any impression whatever upon him. Now and then he asked a question but, for the most part, was content to listen. When I had finished he replied in a sentence:

"I am much obliged to you. I have always known you as friendly to my country and I have no doubt you still are. But our policy in this matter has been well considered."

Then in a flash there came into Baron Takahira's face a look I had never seen there before, as if for one moment he had forgotten his reserve, and in that one moment the native arrogance of a victorious and overconfident people blazed out. He flung his arms wide apart and high, as if to dismiss to the winds all he had heard from me, and what sounded like a battlecry came from his lips :

"We are Japanese. We are Japanese."

As if to say :

"What matters to us any opinion but our own?"

In his metallic tones rang out the invincible belief of the Japanese in themselves and their scarce-concealed contempt for the rest of the world. The sword of the Samurai whistled through the air once again. Not only that. Baron Takahira added:

"If you think it advisable to say anything about this in print, I hope you will let it be seen that we must continue to act on our own judgment."

Not only was he arrogant; he wanted it known that he was arrogant. The answer, of course, was decisive, the rebuff complete, and though I continued 
to see him the subject was not again mentioned. Within less than a week President Roosevelt had notified Japan that American opinion would no longer allow him to press Russia for the payment of the indemnity of $\$ 600,000,000$, and he must appeal to them to withdraw their demand.

\section{III}

Count Witte knew very well what the Japanese were doing and not doing. Every day brought him fresh evidence that he had outwitted those subtle Orientals, whom he understood far better than we did. Once or twice he said to me :

"Your Japanese friends don't seem to take the American public into their confidence."

Once he said :

"I wonder whether Count Komura is aware that there are journalists in Portsmouth, and that there really is a certain amount of American and European interest in our proceedings."

He watched every move in the game. So far as the Conference was concerned, he was disposed to think that the question of Peace and War turned rather upon outside influences than upon what took place in the Conference itself. At any rate, on the decisive point, the payment of a war indemnity by Russia to Japan, his mind as we have seen had been made up in advance and, momentous as the issue was, it could not be much affected by debate between the Plenipotentiaries. Of debate there was little. There was no one language which all the Plenipotentiaries spoke or understood.

I had heard, though not from Count Witte, that at the early meetings the Japanese had been over- 
bearing in manner. They did not seem to be aware that the Members of the Conference met, and could only meet, on terms of equality. That is an elementary and essential maxim of diplomacy. But the Japanese were still new to the methods of the West. They had accepted in theory these traditions and usages of the West, but they wore them as awkwardly as they wore frock-coats and trousers. They were plainly surprised by the tone and attitude of the Russians, and most of all by the jaunty bearing of Count Witte; in whom there was no trace of humbleness nor any touch of that solemnity which the Japanese thought suitable to the occasion.

There could indeed be no greater contrast than between Count Witte and Count Komura. The Russian could have put the Japanese in his pocket; as in the end he did. You hardly realized how big the Russian was till you saw the little brown man beside him; or under the same roof, for I am not sure they ever met in public except in the dining-room of the hotel. Well over six feet tall, powerfully made, loose jointed, broad in the chest, easy in movement though not graceful, a good-natured, smiling giant, the eyes roving, piercing, seeing everything from beneath a lofty forehead and apparently never at rest, he was a child in simplicity of manner, in spontaneity, and in the total absence of any effort at effect. In other days I had known Turgenieff, the one great artist in Russian literature, and it was of him that I was always reminded when with Count Witte. They had the same ready laugh, the same geniality, the same naturalness, the same willingness to meet all comers on a level. You could not but like them and you liked both of them for much the same reasons.

As for Count Komura, he might have come from 
another planet; or from Lilliputia so diminutive was he. I am told the Japanese think us overgrown and that there is a physiological advantage in being undersized; the heart pumping the blood to the brain through shorter channels and therefore with less effort. Grant them that, but still they are not impressive externally. Count Komura did not look the able man he was. An intelligent face, but of parchment written all over in hieroglyphics, a body en lame de couteau, with the mechanical movement of a marionette, a gravity of demeanour so complete that you thought it must be a pose ; eyes and features wilfully expressionless; well, it will out, he looked like a mummy. We have no standard in common with the Japanese to measure them by, and for aught I know what seem to us defects may seem to them high merits, and they might be able to admire Count Komura's appearance as they rightly did his abilities.

It was not till after the Conference was over and done with that I came to know the history, or part of the history, some of which I have written. Count Witte said to me toward the end:

"If we go back on the same ship I can tell you much which here I cannot tell you."

I did go with him on the Kaiser Wilbelm der Zweite, which the Germans thought so perfect a ship that they have reproduced her to the last particular in the Kronprinzessin Cecilie; or meant to, as one of her officers told me. "Tous les goûts sont respectables," remarked Voltaire, to whom respect was not a permanent attitude of mind. The most vivid picture the Count painted of their sittings was at its most critical moment :

"There was a deadlock. Count Komura had laid 
on the table in writing what we understood to be his final demands, including the indemnity. We had made our final answer. We could not accept them. There was no attempt at compromise or even discussion. We had found out before the futility of discussion. Nothing was said. I mean it literally. Not a word was spoken on either side. All of us thought we had reached an impasse and that the conference must break up and the war go on. In the midst of this momentous silence I took out my cigarette-case and lighted a cigarette and began smoking. Then Count Komura took out his cigarette-case and lighted a cigarette and began smoking. I smoked rapidly, and when my cigarette was finished I lighted another and then Komura lighted another. The silence remained unbroken. If there was to be another move it must come from the Japanese, since they had made their proposal and we had rejected it, and we had no counter proposal to offer. Everything turned on the indemnity, and we had made it clear that our refusal to pay the indemnity was not open to revision. It took the Japanese, who had entered upon these negotiations, not as negotiators, but as conquerors, a long time to understand that on this point our minds were immovable and had been immovable from the beginning.

"At last, very slowly, the words dropping reluctantly from his lips, Count Komura said: 'Suppose we adjourn till Tuesday' - -three days off. I agreed to that. Believing the end was upon us, I had looked at my watch as I lighted my cigarette. I looked at it again when Komura made his suggestion. Just eight minutes had clapsed. The Conference had been within eight minutes of utter collapse. We all understood that Count Komura's motion to adjourn till Tuesday 
was meant to give time to communicate with Tokio and St. Petersburg."

Count Witte paused a moment in his story. We had been tramping up and down the deck of the Kaiser Wilhelm. We stopped. I felt sure something else was coming, and it came. Said the Count:

"That was the moment your President chose to intervene; not, as before, to urge my Imperial Master to pay $\$ 600,000,000$ to Japan, but to tell Japan she must withdraw that demand. When we next met Count Komura said, 'I withdraw the demand for an indemnity'; and I said, 'I accept that.' There were other points, as you know, but in those two sentences peace was assured."

"Suppose the war had gone on?"

"We had considered that and, as you know, there was a strong party in Russia which preferred war. There were men about His Majesty the Emperor who pressed it upon him. I was not one. My business was to make peace if I could. But I was never one who thought the military power of Russia exhausted, nor that of Japan invincible in the long run. We reckoned that Japan had money and munitions of war to last till next spring. She would have had a winter campaign before her, deserts and vast spaces to travel as we retired; she growing weaker as she advanced and we stronger as we retreated upon our base. How was she to raise money to go on ? She had pledged everything she had, except her women. Russia had pledged nothing. Her credit was impaired, in a sense, but that only meant that we should have to pay a higher rate for a new loan. The price of issue would have been low but we should have got the money. I did not want to re-enter upon the struggle, but I would infinitely rather have done that than pay 
the indemnity. Who could say with what result ? C'est à la guerre comme à la guerre."

I sum it all up in this way: It was Count Witte who, with that "fortunate astuteness" which is Machiavelli's ideal in $\mathcal{T}$ be Prince, brought the American people back to their ancient friendship for Russia, and with them the President. It was Count Witte who formed that body of American opinion without which Mr. Roosevelt, as I have elsewhere related, never, he said, entered upon a great policy. In so far as the President, having failed to coerce Russia, compelled Japan to renounce her money claim, he was indebted to Count Witte for the opportunity. I go further back than that. It was when Count Witte told the Czar that he would never agree to pay an indemnity, and would go to Portsmouth only on that condition, that the Conference became possible. The Japanese thought he was bluffing. At last, almost too late, the withdrawal of the claim which Japan had never doubted she could enforce, was seen to be the sole alternative to that renewal of the war which Japan had never thought possible. It was therefore first of all Count Witte, and perhaps secondly the Russian Emperor, who were the real authors of the Peace of Portsmouth. President Roosevelt's intervention was useful and was made with great courage and judgment at the right moment. But of itself it would not have availed.

The short specimens I have given you of Count Witte's talk are specimens only. Both at Portsmouth and on the Atlantic his conversation had a quality of its own. If it suited his purpose he was diffuse. He could discourse at length and say nothing not less plausibly than the diplomatist who had spent his official life in that exhilarating practice. He could be 
concise also when he chose, and pack as much into a sentence as most men. At a critical instant of the Conference he was pressed for a statement. $\mathrm{He}$ answered :

"The Treaty between England and Japan has just been revised and renewed for ten years. If you will get me a copy of it I will tell you everything that has passed at the Conference."

A safe offer, but it silenced his questioner. He talked much about Russia and at times a little about himself. I had suggested that he was going back after a memorable victory and that his reward would be memorable. He shook his head :

"You do not know what influences there are against me, nor how close they are to His Imperial Majesty. A decoration, perhaps, but I do not expect to re-enter public life as a Minister. Whatever seems good to the Emperor will be good for me."

This rather melancholy forecast proved true. A title, a place in the Council of the Empire, an order I think, and that was all. But Russia well knew how she had been served and what her debt was to Count Witte. Court favour is, at best, precarious and a Republican may think it of doubtful value. But the great Plenipotentiary of Portsmouth, hitherto little known out of his own country and out of the world of finance, takes a permanent place in history. In a great crisis he had shown great qualities. Out of the nettle danger he had plucked the flower safely. A novice in diplomacy, he overmatched a veteran. He came to Portsmouth an apprentice. He left it a master. In three weeks and in circumstances which would have tested the craft of a Metternich or the genius of Bismarck, he did a service and won a renown which can never pass from the memory of men. What 
matters a ribbon more or less? What matters is that Count Witte is still in the plenitude of his powers, and when Russia again needs a man for another hour pregnant with fate, his unequalled gifts and his devotion will again be hers. 



\section{INDEX}

A

Acheson, Viscount, marriage, 39

Acton, Lord, on his daily reading, 257

Alaska boundary question, 53, 54, $35 \mathrm{I}, 353$

Althorp Library, 146

Sold, I43, seq.

Althorp, Lord, Chancellor of Exchequer, I 39

American after-dinner oratory, 254

American women who marry Englishmen, 37

Arbitration question, 109, 110, 176, 186, 353, 372

Arnold, Matthew ; Oxus, 8

Asquith, H. H.-

"Ambassador," 107

Attitude towards Woman Suffrage, 1 I 7

In Switzerland, 109

Parliament Act, 8, 49, 50, 52

Relations with Winston Churchill, 9I, 95

Surrender to Redmond and Home Rule, I I 4

Tribute to Balfour, 46

Astor, Waldorf, marriage, 269

Astor, William Waldorf-

"Astor Estate" Offices, 264

Buys Cliveden, 265 ; improves it, $267,268,269$

Buys Hever Castle, 270-builds cottages near, 270
Astor, William Waldorf (cont.)-

Buys Observer and other papers, $27 \mathrm{I}$

Characteristics, 262, 264, 269, $273,274,275$

Dinners and concerts, 265

Experiences in England, 201 seq.

Gives Cliveden to his son, 269

Lansdowne House, 263

Naturalized British subject, $26 \mathrm{r}$, 262, 263

Pall Mall Gazette and Magazine, 27I, 272

Astor, Mrs. W. W., 263, 264, 265

B

Balfour, Arthur, $45 \mathrm{seq}$.

As Chief Secretary for Ireland, 55

As debater, 57, 59

At Whittingehame, 55

Attitude towards Anglo-American Disputes, 53, 54, 176

Death Duties, 65

Parliament Bill, 52

Tariff Reform, 48

Woman Suffrage, I 7

Characteristics, 19, 45, 50, 52, $55,56,57$

Compared with Pascal, 5 I Criticism of his policy, 50

Defence of Philosophic Doubs', 112 
Balfour, Arthur (cont.) -

Ill-health, 46

On Winston Churchill in Sidney Street, 91

Proposed Gully as Speaker, 126

Rebellion of followers, 49

Rejects Winston Churchill's application, 9I, 99

Resignation of leadership, 45 seq., 50,60

Bancroft, U.S. Minister at Berlin, $26 \mathrm{I}$

Bath, Marquis of, Longleat and Death duties, 64

Bathurst, Countess, control of Morning Post, 47

Bering fisheries question, 53

Bernhardt, Sarah, 300, 314, 327 seq.

Characteristics, 333

Compared with Desclée, 30I, 302, 303

Hard work, 338

In La Tosca, 337

In Phìdre, 336

On Desclée's acting, 306

Receives Gladstone, 336

Sees Irving in Bells, 326, 327 seq.

Supper at Lyceum, 333 seq.

Bertie, Sir Francis, 199

Biggar, pioneer in obstruction, I 20

Birmingham audiences, 5, 6, 8 Bismarck, Prince, 75, I04, 246

Ems dispatch, 18 I

Borthwick, Oliver, 380

Brand, Sir Henry (Viscount

Hampden) Speaker, II 9 seq.

Characteristics, I 19

On rules of House, I 2 I

Bright, John, 374

As debater, 57

Dramatic gift, 5

On just war, 245
Brington Church, burial-place of Washingtons, 148

British Museum, Tanagra figurines, 23I

Brodrick, St. John, 8 r

Brohan, Madeleine, 300

Browning, as man of society, 28I Bryan, criticism of English rule in India, 162

Buller, Sir Redvers, $8 \mathrm{I}$

Bülow, Prince, 20, 21

Burgon, Dean, 160

Burke, murdered, I 34

Burne-Jones, Sir Edward, pictures, 57

Butler, General Sir William, 81

Byron quoted, I9

Bystander, The, 157

C

Cambon, Jules, I79, I8I

Cambon, Paul, I 80

Cambridge, Duke of, Commanderin-Chief, 80

Campbell-Bannerman, Sir Henry, 107

Canada, relations with United States, 157, I60

Cardwell, Lord, 79

Carey, informer, shot, ${ }_{1} 36$

Carlton Club, disaffection at, 50

Carlyle, Thomas-

On big-nosed men, 166

On Bismarck, 339

Carlyon, Mr., 29I

Carnegie, Andrew-

As captain of industry and apostle of peace, $247 \mathrm{seq}$.

As landlord and neighbour, 259

Deal with Pierpont Morgan, 241 seq.

Dinner to Morley, 253 ; speeches, 254

Friendship with Morley, 252, 253 seq. 
Carnegie, Andrew (cont.)-

Libraries and gifts, 249, 257

Methods in business, 247,248

On Wall Street, 245

Peace Fund, 250

Receives Edward VII, 258

Relations with workpeople, 260

Skibo, 256 ; library, 257, 258

Carnegie, Mrs., 254

Carson, Sir Edward, 49

Carter, John Ridgely, 39

Declines Argentine Mission,200

Cassini, Count, I 86

Cavendish, Lord Edward, 29

Cavendish, Lord Frederick, murdered, 34, 134, I35

Chamberlain, Joseph, I seq.

Achievements, $16 \mathrm{seq}$.

As debater, 9

At Birmingham, 4, 6, 8

Boer War and, 17, 25

Characteristics, I, 2, 3, 4, 7, 10, 14, 19

Colonial policy, 17

Leader on Tariff Reform, 48

Municipal politics, 15

President of Board of Trade, 13

Public speaking, 5, 7

Relations with Sir Charles Dilke, 9 seq.

Reply to Prince Bülow, 20

Tariff Reform policy, I 8

Chambord, Comte de, 282

Champagne, Perrier Jouet, I865, 220

Chatsworth, 33, 34

Chauchard, picture buying, 236

Cherbourg, 385

Chéri, Rose, 300

Choate, American Ambassador, in London, 189

On annexation of Philippines, 2 I 4

Churchill, Lord Randolph-

Dispute with I'rince of Wales, 27

Un Chamberlain, 16
Churchill, Lord and Lady Randolph; at Great Forsters, 87

Churchill, Winston, 87 seq., 256

Administration of Home Office, 95, 100

Argument with Bourke Cockran, 98

As First Lord of Admiralty, roo

At Blenheim, 96

Books, 89

Censures on, 91

Characteristics, 90, 91, 92, 94 seq.

Escape from Boer prison, 89

Joins Liberal Party, 9I

Lectures in America, 89, 90

Life of LordRandolphChurchill, 92

Marriage, 97

Story of boyhood, 88

Clark, Champ, on Canada, 374

Clemenceau, M., 4

Cleveland, President, 3

Interview with Pierpont Morgan, 224

Cliveden, 265, 266

Cockran, Bourke-

Argument with Winston

Churchill, 98

Coquelin as actor, 330,333

Cornell, i 56, i 58, i6 I

Criticism in France and in Eng-

land, 333

Croizette, position in Paris, 300

Cromer, Lord, 367

Cuba, 343

Currie, Lord, 199

Czar, 40I ; gives jewelled sword to General Komaroff, 251

I)

Dalhousic, Lord, 143

Danel of Lille, $23^{8}$

d'Aumale, I) uc, library, 236

Davis, Senator, 192, 194 


\section{ANGLO-AMERICAN MEMORIES}

Day, Judge, 192, 194

Death Duties, 62, 63 Effect of, 64

Debate in House of Commons, 8 , 46

Depew, Senator, 379

Derby, Countess of, 39

Desclée, Aimée, her art, letters, and life, $296 \mathrm{seq}$.

As Princesse Georges, 301, 302, 307

Characteristics, 300, 301, 302, 305, 306, 307

Compared with Sarah Bernhardt, 301, 302. 303

Creates Meilhac's Froufrou, 300, 302, 306

Death, 304, 306, 307

In Paris, 299, 300, 306

Letters to Dumas, 305

" "I'Inconnu de Naples," 304

Lettres à Fanfan, 297, 306

On acting, 305

Rehearsing Visite de Noces, 303

Triumphs, 306

Devonshire, Duchess of (late), 37 seq.

Characteristics, $40,42,43,44$

Daughters, 39

Sketch of career, 38

Devonshire (8th), Duke of, $22 \mathrm{seq}$.

As speaker, 24

Attitude towards Death Duties, 33

Characteristics, 22, 23, 25, 26, $27,30,3 \mathrm{I}, 32,35,36,40,4 \mathrm{I}$, I 39

Intervenes in dispute between Prince of Wales and Lord Randolph Churchill, 27

Interviews with Gladstone, 32 Lismore, 34
Devonshire, Duke of (cont.) -

Lord President of Council, 27

Minister of War, 85

On Boer War, 17, 25

Relations with his father, 35

Statue, 22, 33

Devonshire House, 29

Dilke, Sir Charles-

Relations with Chamberlain, Io seq.

Relations with Gladstone, I I

Under-Secretary for Foreign Affairs, I3

Diplomacy, American and European methods, $198 \mathrm{seq}$.

Methods and language, 206

Principle of continuity in, 200 , 20I, 205

Disraeli, Benjamin (Lord Beaconsfield)-

Admiration for Duchess of Manchester, 39

Attitude towards debate, 8

On Biggar, I 20

On Gladstone's oratory, 124

Quarrel with Goldwin Smith, I 59

D'Oyly Carte, 292

Dufferin, Marquis of, 199

Dumas, Alexandre, fils-

On Desclée, 296, 297, 298, 299

Use made of Desclée's letters, 305

Visite de Noces, rehearsal story, 303

Duplan, Paul, 297, 306

Durand, Sir Mortimer, British Ambassador to U.S., 359

\section{E}

Eddy, Prince (Duke of Clarence), 164

Eden, Lady, portrait, 279, 284

Education Bill (1902), 50 
Edward VII-

Dispute with Lord Randolph Churchill, 27

Liking for Mr. Gully, 126

3rd Batt. Scots Guards and, 116

Visits Carnegie, 258

Egypt, Roosevelt's advice to England on, 367

Criticisms on, 369

Eighty Club dinner to Parnell, I40

Elliot, Life of Goschen, I 54

Emerson-

On taking a man by surprise, 57 On Valdarfer Boccaccio, 147

Empress Frederick, 150

England-

Ambassadors, selection of, 199, 200

Attitude towards United States during war with Spain, I80, I 8 I , 182, 2 I 3,347

Civil servants, 199

Foreign office and diplomacy, 199, 205

England and France, beginning of better understanding, 336

Erckmann-Chatrian, Le Juif Polonais, 327

Esher, Lord, on Territorials, 1 i 5

Expatriation, views on, $26 \mathrm{I}$

\section{F}

Fitzmaurice, Lord Edmund, 380

Forster, Arnold, 79

Forster, W. E., Education Act (1870), 2

Fowler, Sir Henry (Lord Wolverhampton), 107

France, financial solidarity, 216

Franklin, letter to J. Quincypeace and war, 245

Free Trade, 18

Frye, Senator, I92, 194

Fuller, Sir Thomas, Life of Cecil Rhodes, quoted, 325
G

Gambetta, President of French

Chamber of Deputies, 129

Called an opportunist, 72

Provisional government at Bordeaux, 2 I 5

Weight of brain, 7

Garrett, Edmund, story of Cecil

Rhodes and, 325

Garrick, Irving compared with, 318,326

Garvin, editor of Observer, 271 ; and Pall Mall Gazette,272,273

On Lord Goschen, 155

George $\mathrm{V}$ of Hanover, 38

George, Lloyd, 23

Censures on, 9 I

Budget, 62, 98, I 14 ; effects of, 267,273

Object of Death Duties, etc, 267

German philosophy and science, I I 2 II 3

Germany, attitude towards expatriation, 26I

Gilbert, Sir William Schwenck, $289 \mathrm{seq}$.

As Justice of the Peace, 290

Association with Sullivan and D'Oyly Carte, 292

Characteristics, 289, 290, 291, 292, 293

Eulogies on and anecdotes, 289

Influence on stage, 294, 295

Tuition of actresses, 293

Gilchrist, Connie (Countess of Orkney), portrait, 279

Gilder, Mr., 254

Gladstone, IV. E., 4, 73, 164

Appreciation of Morley, 252

As debater, 57

As leader, IO, I2, I 3

Attitude towards debate, 8

$\begin{array}{lll}" & \text { " } & \text { Gordon, } 84 \text { seq. } \\ " & \text { " } & \text { Goschen, I } 55 \\ \text { " } & \text { " Navy, I41, } 142 \\ , & \text { " } & \text { Radicalism, } 10\end{array}$




\section{IO ANGLO-AMERICAN MEMORIES}

Gladstone, W. E. (cont.)-

Dramatic gift, 5

Foreign policy, 74, 75

Home Rule Bill (I 886), I4, I38, I 95

- Revolt against, 155

Interviews with Lord Hartington, 32

Liking for Whitelaw Reid, 196

Nominates Arthur Peel as Speaker, 123

Notion of peace, 251

On Sir Edward Grey, Ioz

Proposed Gully for Speakership, 125

Reply to Sir Charles Dilke, I I

Seeing Sarah Bernhardt in Phèdre, 336

Stories of, 380

Views on Cabinet-making, I I, 75

Glenesk, Lord, owner of Morning Post, 47

Godley, Sir Arthur, 380

Gordon Relief Expedition, 8o, 84

Gorst, Sir Eldon, 367

Goschen, Viscount (the late), I49 seq.

As man of business, I49

As speaker and debater, 153

Conversation, I 50, I 54

Description of himself, I 49

Founds Unionist Party, 155

Free Trader, 152

Led revolt against Home Rule, I 55

Offices held and declined, I 54

Personal appearance, 152

Theory of Foreign Exchanges, I 52

Gosford, Countess of, 39

Grant, General, 370

Granville, Lord, 77

Gray, Senator, 192, 194
Greeley, $\$$ Horace, I 89

Greenwood, Frederick, 272

Grenville, Stamp Act, 8

Grey, Sir Edward, 75, 102 seq.

Characteristics, 105, I06, III

Fishing, 102

Foreign Minister, 107, 108

Radicalism, 107, 108, I I7

Speeches on Arbitration and Moroccan Question, 102, I09, 176

Under-Secretary for Foreign Affairs, 103, I05

With Roosevelt in New Forest, 103

Grey, Lady, character, Io6

Griscom, Lloyd, United States

Ambassador to Rome, 202

Guibert, M. de, 298, 299

Gully, Viscount Selby, as Speaker, 125, 126

\section{$\mathrm{H}$}

Hague Tribunal, I 10

Haldane, Viscount, i I 2 seq.

"Ambassador," 107, II 4

As Socialist Radical, I 17

As War Minister, II 4

Characteristics, II2, II4, II6, I 18

Practice as barrister, II 4

Scheme for army, 79

Speech on army reorganization, I 3

Translates Schopenhauer, II 3

Halsbury Club, 49

Halsbury, Lord, attitude towards

Parliament Bill, 49

Halstead, on New York addresses, $24 \mathrm{I}$

Hamilton, Duchess of, 39

Hampden, John, I 19

Hanbury, Lily, 293 
Harcourt, Sir William, 6r seq.

As jurist, 67

Attitude towards Navy, I4l, 142

Characteristics, 62, 66

Crimes Act, 135

Death Duties, 33, 62, 63, 64

Dispute with Lord Rosebery, 65

Malwood, 66

On great Americans, 148

Relations with his son, 6 I

Hardinge, Sir Charles, 199

Harrison, Frederic, 379

Harrison, President, r9I

Hartington, Lord. See Devonshire, Duke of

Haversham, Lord and Lady, 153

Hay, Anerican Ambassador in London, 189

Effect of his diplomacy, 347

On value of continuity in djplomacy, 201, 202, 204

Secretary of State, 351, 352

Hayward, as a social force, $28 \mathrm{I}$

Heber, Richard, buying libraries, 237

Henry of Prussia, Prince, mission to U.S., 355

Herbert, Sir Michael, British Ambassador, 199, 354

Heredity, 128

Hertford, Marquess of, I 39

Heseltine, lover of art, 293

Hever Castle, 270

Hitt, 2II; on way of passing bills, 209

Holden, Sir Isaac, 63

Holleben, Baron, 182, I85, I 36

Homburg, von der Höhe, I25

Home Rule :

Opinion in America on, 195

Wolseley's judgment of, 86

Home Rule Bill (first). See under Gladstone
Houghton, Lord, 309

Speech at Irving's supper, 3 IO, 3I I

House of Commons :

Debate in, 8

Obstruction in, 120

Rules, I2O, I 2 I

Standing Orders, I22, I 30

House of Representatives, Washington, 122

Hugo, Victor, on receiving Emperor of Brazil, 336

Huxley, Professor, I9

On death, 44

On Germans as scientists, 113

\section{I}

Invective in debate, 83

Ireland, murders in, 135,136

Irish in New York, 90

Irish influence in U.S., decay of, 212

Irish Nationalists, policy of obstruction, I 20

Irving, Sir Henry, 308 seq.

As artist and man, 314 seq.

"Becket, 3I 8, 320

"Hamlet, 326

" Iago, Lear, and Othello, 324

" Macbeth, 324, 326

"Manager of Lyceum, 31 3

"Mephistopheles, 3 I 4 seq.

"Richelieu, 318, 320

"Wolsey, 317, 318, 320, 32 r

Characteristics, 308, 310, 317 , $3^{19}, 321,322,323$

Compared with Garrick, 3I8, 326

Criticism and finance, 312,313

In Bells, 326, $327 \mathrm{seq}$.

Influence, 316

Resemblance to Mianning, 317 , 320

Study of actors and audiences, 322 


\section{I 2 ANGLO-AMERICAN MEMORIES}

Irving, Sir Henry (cont.)-

Supper on hundredth night of Merchant of Venice, 309 seq.

Supper to Sarah Bernhardt, 333 seq.

$\mathrm{J}$

James, Henry, on Irving in Bells, 330

Japanese, attitude towards Americans and Roosevelt, 366

Jersey, Lady, 37

Journalists :

At Portsmouth, 361, 390, 39I, 392

Relations with actors, 324

$\mathrm{K}$

Khartoum, siege of, 85

Kitchener, Lord, I 5

In Egypt, 370

Knox, head of American Foreign

Office, 20I, 204

Komaroff, General, $25 \mathrm{I}$

Komura, Count, 365

At Portsmouth Conference, 390, 393, 395, $398 \mathrm{seq}$.

Characteristics, 398

Contrasted with Witte, 397

Demands war indemnity, 363

$\mathrm{L}$

Langtry, Mrs., 278, 280

Portraits, 278, 279

Lansdowne, Lord, 49

War Minister, 8I

Laurier, Sir Wilfrid, 351, 353

Minister of Finance, 215

Law, Bonar, as leader, 45

Lawley, Frank, 68, 7o

Leighton, Lord, originates Winter

Exhibition at Royal Academy, 234

Lespinasse, Mlle. de, letters, 298,299
Lewis, Sir George, 94

Lincoln, President, 6

Lodge, Senator, 54

Loeb, as Secretary to Roosevelt, $347,361,362$

Collector of Port of New York, 361

Londonderry, Lady, 58

Lonsdale, Earl of, 128

Lowe, R., on Lord Hartington, 31

Lowther, James, Speaker, I 27 seq.

Compared with Gambetta, 129, 208 ; with "Tom" Reed, 208

Qualities, I29, I30, $1_{32}$

Lowther Lodge, I 29

Lowther, Mrs., I 29

As hostess, I 3 I, I 32

Lowther, Hon. William, sketch of, 128

Lucy, Sir Henry--

"Essence of Parliament," 59

On Sir Edward Grey, 108

Lyndhurst, Lord, on Brougham,

\section{$\mathrm{M}$}

Macaulay, Lord-

On Grenville, 8

On Orientals' homage, 221

Machiavelli, Prince, "fortunate astuteness," 40I

McCormick, U.S. Ambassador to France, 202, 203

McKenna, R., leaves Admiralty, 100

McKim, Miller, 237

McKinley, President, 205, 352

Agrees to acquisition of Philippines, 188, I9I, I94

Appoints Peace Commissioners, 192

Manchester, (7th) Duke of, 38

Manning,Cardinal,compared with Irving, 317,320

Marlborough, (Ist) Duke of, I 39

Marlborough, (7th) Duke of, 94 
Marlborough House, garden party, I 64

Meyer, U.S. Ambassador to St. Petersburg, 202

Interviews with Czar, 364

Midleton, Lord, 79, 8I

Millais, Sir John--

Portrait of Gladstone, I 40

Portrait of Cardinal Newman, 320

Miller, Joaquin, poem for Carnegie's birthday, 258, 259

Mills, D. O., I 90

Milner, Lord, I6I

Minto, Lord and Lady, in Ottawa, 89

Monroe Doctrine, I IO, 204

Morawetz, Victor, 243, 244

Morgan, Junius S., 2 I 5 seq.

Characteristics, 219

Death, 220

Dover House, $217 \mathrm{seq}$.

Laurier loan, 215, 223

Morgan, Pierpont, 22I seq.

Art gifts and loans, 234

As collector, 230, 23I, 232, 236

Buying pictures, 235

Collections, 236

Deal with Carnegie, $242 \mathrm{seq}$.

Encounter with President Roosevelt, 240

Financial anecdote of, $22 \mathrm{I}$

Financial methods, 226, 227 , 228

Gosford Library, 237; catalogue, 238

Interview with P'resident Cleveland, 224

Library, 236, 237

Likes power, 239, 240

Meets German Emperor, 239

Services to his country, 240

Morley, Lord, 73

Address at Pittsburg, 253

Compared with Goldwin Smith, 161

Edited Pall Mall Gazette, 272
Morley, Lord (cont.) -

Friendship with Carnegie, 252, $253 \mathrm{seq}$.

Influence with Gladstone, 252

Life of Gladstone, I I

- On Gordon Relief Expedition, 85

- On Lord Spencer, I 37

On Gladstone's notion of peace, $25 \mathrm{I}$

Reviews Roosevelt's Cromavell, 379

Morning Post, attitude towards Balfour, 47 seq.

Moroccan question, I02

Morris, Sir Henry, 167

Morton, Governor, 213

Murders in Ireland, 135,136

\section{$\mathrm{N}$}

Napoleon on idéologues, 3

National Liberal Federation, I6

Neilson, Julia, 293, 294

Neilson-Terry, Miss, as Viola, 294

New Radicalism, growth of, IO, 13

New York directories, 24I

New York, parent of "skyscrapers," 190

Newman, Cardinal, 320

On Pope's infallibility, 358

O

Observer, bought by Astor, $27 \mathrm{I}$

Obstruction in House of Commons, 120

O'Donnell shoots Carey, $\mathrm{I}_{3} 6$

Olney, Mr., 53, I76, 244

First Arbitration Treaty between England and United

States, 177,178

Osborne, Bernal, 282

Ottawa, $35 \mathrm{I}$

Government House in, 89

Outlook, attitude towards Taft, 373

Oyster Bay, $341,342,361,362$ 


\section{I 4 ANGLO-AMERICAN MEMORIES}

$\mathrm{P}$

Pall Mall Gazette, owned by Astor,-editors, 272

Palmerston, Lady, 37

Palmerston, Viscount, 19

Conception of British Fleet, 10.4

Use of social influence, 56

Parliament Bill, 8, 49, 50, 52, I I 8

Paris theatres, their influence, 336

Parnell, C. S.-

Attitude towards Phœenix Park

Murders and Crimes Act, I 35

Policy of Obstruction, 120

Parry, Serjeant, Counsel for Whistler, 277

Pascal-

Pensées, 50

Provincial Letters, 50

Pauncefote, Lord-

As Anglo-American Ambassador, $170 \mathrm{seq}$.

Attitude towards Senators, 178

Characteristics, $172,173,174$, 183

Conspiracy against, I8o seq., 348

Death and funeral, I86, 187

Doyen of Diplomatic Corps, 186

First Arbitration Treaty with

United States, 177,178

Influence with Roosevelt, 347

Permanent Foreign Under-

Secretary, 171, 199

Peel, Arthur (Viscount)-

As Speaker, $123 \mathrm{seq}$.

Oratory, 124, 125

Peel, George, Future of England, quoted, IO I

Peel, Sir Robert (first), 124

Pembroke, Earl of, Wilton and Death Duties, 64

Penjdeh incident, 251

Philippine Isles acquired by United States, I88, I9 I seq.,

Phœnix Park murders, I 34, I35

Pitt (younger) portrait, 4
Pittsburg, 260

Morley's address at, 253

Platt, Mr., 379

Portsmouth, Conference between Russia and Japan at, $360 \mathrm{seq}$.

Portsmouth, Peace of, real authors, 401

Press--

American, attitude on Portsmouth Conference, 390, 394

Methods of English and American, 368

Use of, 348

Prince of Wales. See Edward VII

Psychical Society, 5 I

Punch-

Caricatures of Palmerston and Lord John Russell, 6

"Essence of Parliament," Prince Arthur, 59

On Tree's stage properties, 320

Q

Queen Mary, I64, 165

Queen Victoria, I64

Influence and authority, 73

On Lord Rosebery as Foreign Minister, 74,78

$\mathrm{R}$

Rachel (Elizabeth Rachel Félix), 327

As actress, 300, 301

Radnor, Earl of, Longford and Death Duties, 64

Redford, reader to Lord Chamberlain, 295

Redmond, J. E., 95

Reed, Thomas B., American Speaker, $208 \mathrm{seq}$.

Attitude towards annexation of Philippines, 2 I 4

Characteristics, 2 I I, 2 I 2

Compared with James Lowther, 208

On Irish influence in America, 2 I 2 
Reid, Mrs., I89, I90, 197

Reid, Whitelaw, American Ambassador in London, I $88 \mathrm{seq}$., 201

Advocacy of Anglo-American friendship, 196

As editor of Tribune, i 89

Attitude towards annexation of Philippines, 192, 193, 194

Career, I 88, I89, 19 I

Love of books and of letters, 197

Marriage, 190

Questions treated, 196

Speeches, 197

Rhodes, Cecil, 17

Story of Edmund Garrett and, 325

Roberts, Lord, in South Africa, 80 Roosevelt, Alice, (Mrs. Long. worth), 343

At King Edward's funeral, 371

Roosevelt, Mrs., 341, 343, 351

Roosevelt, Theodore, 179, 188 , $339 \mathrm{seq}$.

Alienated business world, 349

Anecdotes of, 342, 345, 349, 35 I $376,379,380$

As Governor of New York State, $343 \mathrm{seq}$.

As President of New York City

Police Board, 340 seq.

As President of U.S., 346 seq.

- Relation to Foreign Affairs, 352 seq.

At King Edward's funeral, 37 I

Attitude towards Arbitration

Treaties, 176 , 372

" $\quad$ England, 347,

373,374

$" \quad \quad \quad$ Law, 381,382

" $\quad$ "Paunc ef ote, I85, 186, 348

, , $\quad$ Taft, 373

loer partialities, $347,373,374$

Cables to St. Petersburg, 364 ; to Tokio, 365
Roosevelt, Theodore (cont.)-

Characteristics, 340, 34I, 342, $346,348,349,356,358,370$, 372,376

Compared with Kaiser, 357

Confidence in Hay, 352

Coquetries with O'Connor, 374

Cromzell, 379

Dealings with Ambassadors, 358,359

Encounter with Pierpont Morgan, 240

Hunting in Africa, 371, 375

Intervention between England and Egypt, $366 \mathrm{seq}$.

"Russia and

Japan, 360 seq., 396 , 400,401

Military excursion in Cuba, 343

On good and bad trusts, 246

Politics, 352

Reception of Prince Henry, 355

Relations with German Emperor, 355

Relations with Senate, 377

Speech on Supreme Court, 381

"Teddy," 87

With Sir Edward Grey in New Forest, IO3

Root, Mr. 244

Acted on Hay's diplomatic policy, 202, 204

Rosebery, Lord, I9, 68 seq.

Advice on Tariff Reform, 72

"Ambassadors," 107

As Foreign Minister, 74 seq., IO4, 186

As orator and debater, 59

Attitude towards Gladstone, 74

Characteristics, 70, 71, 72, 78

Conception of British fleet, $\mathrm{IO}_{4}$

Diplomatic equipment, 77

Dispute with Sir William Harcourt, 65,71 


\section{I6 ANGLO-AMERICAN MEMORIES}

Rosebery, Lord (cont.)-

Misunderstood, 7 I

On heredity, I 28

Prime Minister, 73

Speech to Imperial Press Conference, 205

Use of social influence, 56

Rosecrans, General, I89

Rothschild, Baron Alphonse de, collections, 23I

Story of, 232

Rothschild, Baron Meyer de, 69

Mentmore, 70

Rothschild, Lord, on Death Duties, 63

Ruskin, John :

Criticism of Whistler, 277

On art, $15 \mathrm{I}$

Russell of Killowen, Lord, $33^{\circ}$

On Sir George Lewis, 94 Rylands, Mrs., buys Althorp Library, 144

\section{$\mathrm{S}$}

St. Albans, Duchess of, 282

Salisbury, Marquis of, $27,49,53,54$

Foreign policy, 75

On British fleet, IO4

On qualities essential to a diplomatist, 76

Relations with United States, I7 1

Retirement, 75

Use of social influence, 56

Sanderson, Lord, 18I

Sardou, La Tosca, 337

Sargent, on his portraits, 97

Saunderson, Colonel, reasons against Home Rule, 34

Sauvageot, art collection, 236

Schopenhauer, II 3

Scots Guards, 3rd Battalion, and King Edward, i 6

Sedan battle, 10 f

Selborne, Lord, 49

Shaw, on Morgan's art collections, 234
Smith, Goldwin, Scholar and A postle, $156 \mathrm{seq}$.

As journalist, 157, I 59

Compared with Lord Morley, I6I

Letters, 156

Oxford career, 160

Quarrel with Disraeli, 159

Reminiscences, 25

Style, 159

Theory about Canada, I 57, I60, 162

United States: An Oulline of Political History, 158

South African War, 17, 25

Speakers of the House of Commons, 119 seq.

House, 132

Salary, 133

Spencer, Earl (rst), I 39

Spencer, Earl (5th), 73, 92, I 34 seq.

As First Lord, I4I seq.

As Irish Viceroy, I 34 seq.

Characteristics, I37, I39, I4I, $144,145,147,148$

On Gladstone's influence, I 4 I

Sells Althorp Library, I $43 \mathrm{seq}$.

Supports Home Rule, 138

Spencer, Lady, I 37, I39, I45, 146 Spencer, Robert (6th Earl), I34, I 35,140

Spencer, Mrs. Robert, 140

Spencer House, 143

Standard Oil and Tobacco Trust, 381

Stead, edited Pall Mall Gazette, 272

Steel Corporation, 248,249

Stetson, Lynde, 243,244

Stoker, Bram, 321

Story, Waldo :

Bas-reliefs, 105

Statues at Cliveden, 268

Sullivan, Sir Arthur, 292

Sunderland (3rd) Earl of, 139

Sutherland, Duke of, on Carnegic as neighbour, 259 
$\mathrm{T}$

Taft, President, 188,355

Accepts White's resignation, 203, 204

Arbitration Treaties, 110, 176, 353,372

Fame, 373

Proposes an Arbitral Court, 110

Taine, on root of philosophy, 58

Takahira, Baron, 365, 393 seq.

Talleyrand, on everybody's wit, 231

Tariff Reform, I 8, 48

Taylor, General, President Zachary, 98

Teck, Duke of, 164

Teck, Duke and Duchess of (late), 163

Teck, Prince Francis of, 163 seq. As Chairman of Middlesex Hospital, 167

As soldier, 166

Automobile Club, 167, 168

Characteristics, 166, 168

Death, I65, 169

Teck, Princess Mary of. See Queen Mary

Tennant, Sir Charles, 140

Tennant, Sir Edward, 140

Territorials, I I 5

Trade Union Bill, 50

Tree, Sir Herbert, 318, $3 \mathbf{I} 9$

As Wolsey, 319, 32 I

Henry the Eighth, 317

Trevelyan, Sir George, Chief Secretary for Ireland, 136

Tribune, The (New York), I3, 120 Appreciation of Sir Julian Pauncefote, 175

Policy on Home Rule, 195, I 96

Whitelaw Reid as editor, I 89

Thomas, General, 189

Turgenieff, compared with Witte, 397

Turner, Mr., 54
United States-

No system of diplomacy, 204, 206

Officers of State badly paid, 2 I I

Penurious policy towards Ambassadors, 189,200

Senate and House of Representatives, 2 Io

Senate, attitude towards arbitration, $177,35 \mathrm{I}, 353$, 354,372

" President, 2 I I

Supreme Court, $38 \mathrm{r}$

War with Spain, I79

- Peace Commissioners, I9I seq.

\section{V}

Vanderbilt, W. H., on making money, 239

Venezuela question, $53,55,76,176$

\section{W}

Waddington, M., dinner of farewell to, 125

Wallace, Sir Donald Mackenzie, 361,362

Wallace, Sir Richard, collections, 235,236

Ward, Mrs. Humphry, letters on woman suffrage, 109

Washington-

Climate, 360

Mourning for Lord Pauncefote, 187

"The Embassy," I 86

Washington, Booker, 379

Washington, Lawrence, burialplace, 148

Webster, Daniel, on religion and politics, 285

Westminster, Duke of (late)-

Liking for Queen Anne architecture, 268

Sells Cliveden, 265

Stories of, 140 


\section{I8 ANGLO-AMERICAN MEMORIES}

Whistler, James McNeill, $276 \mathrm{seq}$.

Action against Ruskin, 277

Books and letters, 276

Breakfasts, 280

Characteristics, 28I 282,283 , $284,286,288$

Pencil drawing, 276

Portraits, 279, 287

Quarrel with Royal Academy, 286

Reply to invitation from Art Society, 287

Story of, 282 ; Disraeli's portrait, 284

White, Henry, U.S. Ambassador to France, 39, 203

Mission to S. America, 203

William, Emperor of Germany-

As ruler, 357

Meets Pierpont Morgan, 239

Policy towards England and United States, 179, 182

Relations with Roosevelt, 355

Witte, Count, 36I

Account of Conference, $398 \mathrm{seq}$.

At Portsmouth Conference, 363 , $364,366,383,390$ seq., 4 O I Audience of President, 362 Characteristics, $385,386,387$, $389,397,401,402$
Witte, Count (cont.)-

Contrasted with Komura, 397

Conversation, $40 \mathrm{O}$

Relations with journalists, 39I, 392

Sketch of career, 387

Wolff, Sir Henry Drummond, 199

Wolseley, Field-Marshal Viscount, $79 \mathrm{seq}$.

Characteristics, 83,84

Commands Gordon Relief Expedition, 86

Conversation and invective, 83

On Home Rule, 86

Passed over in Boer War, 8I

Photograph, 82

Short service, 80

Sketch of career, 80

Wolseley, Lady, $8 \mathbf{I}$

Woman Suffrage question, 108, I 7

Wyndham, George, 49

$$
\text { Y }
$$

Young, John Russell, managing editor of Tribune, 120

Z

Zobeir, 85 
. 
UNIVERSITY OF CALIFORNIA

Santa Barbara College Library

Santa Barbara, California

Return to desk from which borrowed.

This book is DUE on the last date stamped below. 
UC SOUTHERN REGIONAL LIBRARY FACILIT

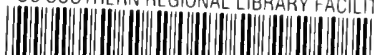

AA 0002807097 

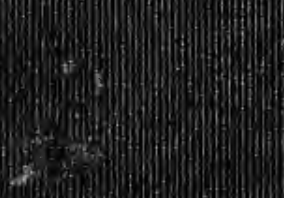

$$
\ldots
$$
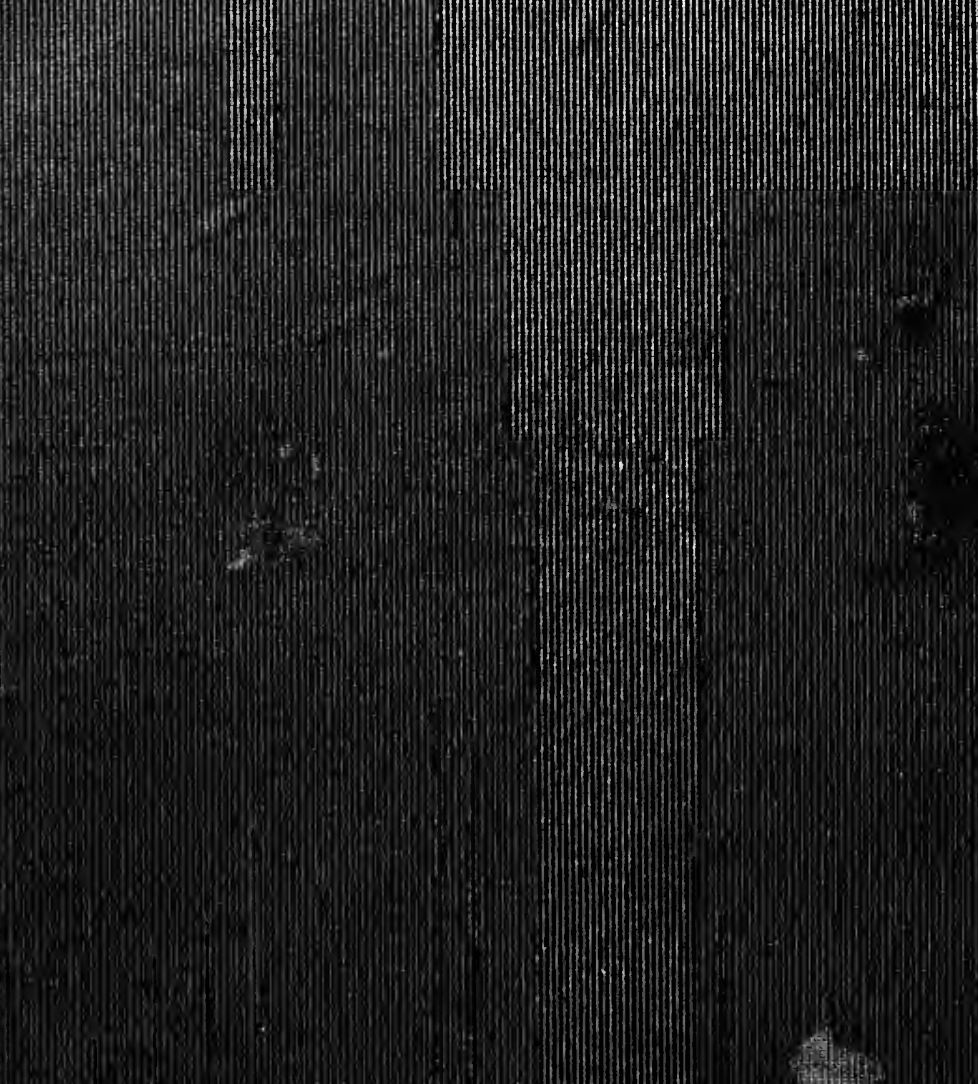

(1)

(I)

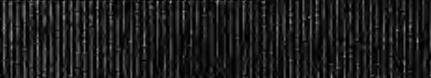

